\title{
Core Historical Literature of Agriculture
}

Home

Search

Browse

Bookbag

Help

The fig

Table of contents | Add to bookbag

First Page

\section{Page i}

New York

State College of Agriculture

At Cornell University

Ithaca, N.Y.

Library

Front Matter

\section{Page ii}

I ra J udson Condit was born in 1883 at Jersey, Licking County, Ohio. After graduation from the High School at Granville in 1900 he taught in a country school at the age of 16 . He received the B.Sc. degree from Ohio State University in 1905 and then spent over a year in the Division of Entomology, United States Department of Agriculture, Washington, D. C. From 1907 to 1912 he was Instructor in Botany and Horticulture at the California Polytechnic School, San Luis Obispo, where he married Caroline Callender. The following year was spent in graduate work at the University of California. In 1913 he was appointed Instructor and later Assistant Professor in the newly organised Division of Citriculture of the University, where he spec. alized in the study of subtropical fruits and published bulletins on the loquat, persimmon, avocado, carob, and caprifigs and caprification. From 1920 to 1924 he was horticulturist for the California Peach and Fig Growers zvith headquarters at Fresno and became intimately acquainted with $t$ the fig industry and its cultural problems. Following his return to the University of California he was granted the degree of M.S. in 1928 from that institution and the Ph.D. degree from Stanford University in 1932. He has made 
morphological studies of the flowers of the common fig and cytological studies of over thirty species of the genus, Ficus, and for many years has investigated the problems of olive culture in California. Since 1935 he has been Associate Professor and Associate Subtropical Horticulturist at the University of California Citrus Experiment Station, Riverside, where his main project has been the study of fig varieties, their nomenclature and climatic adaptation, and development of new varieties by extensive fig breeding. At the invitation of the California Fig Growers he spent six months in 1923 becoming acquainted with the fig industries of Old World districts, particularly Algeria, Italy, Greece, Turkey, France, Spain and Portugal. During sabbatical leave in 1934-35 he was visiting Professor at Lingnan University, Canton, China, and also visited the Philippines, Formosa, Japan, and Hawaii. He is an active member of the following professional societies: A.A.A.S., Amer. Soc. Hort. Sci., Sigma Xi, and Calif. Bot. Society. He is editor of the section Subtropical and Tropical Pomology, for Biological Abstracts.

\section{Page iif}

\section{A NEW SERI ES OF PLANT SCIENCE BOOKS}

edited by Frans Verdoorn Volume XIX

The FIG

\section{Page iv}

The central fig tree shows a method of propagation known as marcottage or aerial layering, commonly used

in some humid climates. Note bags of moss in which roots are forming, also some roots on severed branches which are ready to plant (from: Versuch der Universal Vermehrung aller Baume by G. A. Agricola, Vol. 1, Regensburg,

1716, courtesy Arnold Arboretum of Harvard University).

\section{Page vi}

First published MCMXLVII

By the Chronica Botanica Company

of Waltham, Mass., U. S. A. 
Copyright, 1947, by the Chronica Botanica Co.

All rights reserved, including the right to reproduce

this book or parts thereof in any form

Authorized Agents: New York, N. Y.: Stechert-Hafner, Inc.

31 East 10th Street.

San Francisco, Cal.: J. W. Stacey, Inc.

551 Market Street

Ottawa, Ont: Thorburn and Abbott, Ltd.,

115, Sparks Street.

Mexico, D. F.: Axel Moriel Sucrs.,

San J uan de Letran 24-116; Ap. 2762.

Lima: Libreria Internacional del Peru,

Casa Matriz. Boza 879; Casilla 1417.

Santiago de Chile: Libreria Zamorano y Caperan,

Compania 1015 y 1019; Casilla 362.

Rio de Janeiro: Livraria Kosmos, Rua do Rosario, 135-137; Caixa Postal 3481.

Sao Paulo: Livraria Ovilizaqao Brasileira,

Rua 15 de Novembro, 144.

Buenos Aires: Acme Agency, Soc. de Resp. Ltda.,

Suipacha 58; Casilla de Correo 1136.

London, W. 1: Wm. Dawson and Sons, Ltd.,

Chief Agents for the British Empire

Cannon House, Macklin Street. 
London, W. C. 1: H. K. Lewis and Co., Ltd.,

136, Gower Street. Uppsala: A.-B. Lundequistska Bokhandeln.

Groningen: N. V. Erven P. Noordhoff.

Chief Agents for Continental Europe.

Paris, VI: Librairie H. Le Soudier,

174, Bvd. St. Germain.

Torino: Rosenberg \& Sellier,

Via Andrea Doria 14.

Lisbon: Livraria Sa da Costa,

100-102, R. Garrett.

Moscow: Mezhdunarodnaja Kniga,

Kuznetski Most 18.

Calcutta, Bombay, and Madras: Macmillan and Co., Ltd.

J ohannesburg: Central News Agency, Ltd., Commissioner \& Rissik Sts.; P. O. Box 1033.

Sydney: Angus and Robertson, Ltd.,

89 Castlereagh Street, Box 1516D.D. G.P.O.

Melbourne, C. 1: N. H. Seward, Pty., Ltd.,

457, Bourke Street.

Made and printed in the U. S. A.

\section{Page vii}

\section{FOREWORD}

I am glad to have the privilege of writing a foreword to Dr. Ira J. Condit^ important work, "The Figl 'I' which gives a highly documented account of this 
remarkable fruit and its near relatives. Dr. Condit has been publishing valuable contributions to our knowledge of the jig during the last thirty years. Chronica Botanica deserves great credit for publishing very useful historical and scientific records of plants such, as this monograph. Now that the rapidly augmenting population in most countries has raised the grave problem of the future supply of food for the ever-increasing millions of human beings their energetic editorial and publicational activities should be recognized as a real contribution to the solution of the vital problem of feeding the world.

As with the introduction of many new plant industries there was an almost inexplicable lapse of time between the introduction of the first Smyrna fig cuttings into the New World in 1880 and 1882 and the actual production of caprified figs on a commercial scale. Until 1890 no fruit was produced on any of the thousands of flourishing trees and then only a few experimental fruits resulting from slow and difficult hand pollination. Bui another ten years was to elapse before the introduction of the Blastophaga insect. Many claimed that the Turks, not wanting to lose their large export trade of Smyrna figs to this country, had sent cuttings from sterile fig trees. During all this time discussion still raged as to the value of caprification. This was probably the result of the publication in 1892 of a translation of the Italian Professor GasparriniV chapter on caprification in which he vehemently denounced the practice, saying, "Caprification is useless for the setting and ripening of the fruit and this custom, which entails expense and deteriorates the flavor of the fig, ought to be abolished from our agriculture."

It is strange that the fig growers of California did not realize that the Mission and White Adriatic figs and many other varieties, were like the Washington Navel oranges of nearby Fresno and Tulare Counties in that they did not need pollination to set fruit. On the other hand the Lob Injir and other Smyrna figs were like the Valencia oranges and needed pollen to set fruit and never produced any figs until they were pollinated artificially on a very small scale in 1890, or on a large scale after 1900 when caprification began in California.

I first saw the fig insect and the practice of caprification and talked with I talian fig growers in 1896 when for some months I occupied the Smithsonian Table at the Marine Biological Institute at Naples, Italy. There I met Dr. Paul Mayer, an entomologist who had studied caprification and had published a fifty-page illustrated memoir in Vol. 3 of the Mitteilungen of the Naples Zoological Station in 1882. Traveling there again at my

\section{Page viii}

Condit

vni 


\section{The Fig}

own expense in March, 1898,I was given the courtesy of this great Institution. One day while I was busily wrapping in tinfoil caprifigs containing Blastophaga to send to America, Dr. Paul Mayer brought into my room Count Solms-Laubach, a famous German botanist who had published a bulky treatise on the fig some 16 years before. He said at once, "Why do you Americans spend good money to come to Europe to study things already decidedt Gasparrini showed fifty years ago that figs do not need to be caprified to set fruit and that pollination has no beneficial effect. This is merely a peasant superstition. Why did you not study the flora of the Revilla Gigedo Islands and so accomplish something useful and interesting?"

I did not even know the location of the Revilla Gigedo Islands ffar to west of the State of J alisco, Mexico) but I was thoroughly convinced of the need for caprification to cause Smyrna figs to set fruit because I knew of the proof published by George C. Roeding and Gustav Eisen in 1891. On trees which had hitherto been completely sterile they produced beautiful plump Lob Injir figs by artificially pollinating the young fruit with pollen from California-grown caprifigs by pushing it into the young fig or blowing it in through a quill. As hand pollination was hopelessly slow and costly I knew we must establish the Blastophaga in the caprifig trees then growing in California in order to produce Smyrna figs on a commercial scale.

My first shipment of fig insects from Naples in March, 1898, although it arrived in good condition was too late for the Blastophaga to enter the spring generation caprifigs. In the winter of 1899, as an Agricultural Explorer for the Plant Introduction Service of the Department of Agriculture, fjust organized by Dr. David Fairchild) / visited North Africa where I felt sure I could get caprifigs a few weeks earlier than at Naples. I sent six boxes of winter generation caprifigs from the J ardin Botanique at Algiers wrapped in tinfoil, just as the first shipment had been. These reached Dr. L. O. Howard, Chief of the Bureau of Entomology, by March 31 and were sent by him to George C. Roeding at Fresno, California, where they arrived April 6 and were placed under a caprifig tree with a cheesecloth cover. A few Blastophaga escaped from the tented tree which had no fruits at the proper stage to be entered) and laid their eggs in spring generation caprifigs outside. From these the female Blastophaga escaped in J une and pollinated not only a few Lob I njir figs but also a number of summer generation caprifigs. In the autumn of that year I found in California many thousands of Blastophaga psenes flying around and entering the caprifigs, the latest of which would overwinter on the tree. The offspring of these insects are now so well established that thousands of tons of caprified figs are produced annually in California.

Walter T. Swingle

4753 Reservoir Road NW Washington, D.C. J uly, 1947 


\section{AUTHORI'S PREFACE}

In writing this book I have two purposes in mind. The first is to gather into one volume the essential facts regarding the figfacts presented by other authors but heretofore available only in periodicals and books found on library shelves. My second purpose is to share, with all who are interested, the results of my own study and research in California during the last thirty years.

What knowledge I have of the practical aspects of fig culture was obtained largely during a five-year association with the industry at Fresno, California. Information regarding the principal fig districts of the Old World was gained in 1923 when I visited Algeria, I taly, Greece, Turkey, Spain, Portugal, and southern France. My research work on the fig has been done at the University of California, Berkeley, and at the University of California Citrus Experiment Station, Riverside.

One might expect to find that numerous books have already been written about a fruit of such ancient origin as the fig, but the fact is that the present bibliography contains only two titles which can properly be classed as books. One of these, II Fico, by F. Vallese (1909), covers the culture of figs in southern Italy; the other, La Higuera y su Cultivo en Espana, by Pedro Estelrich (1910) is descriptive of figs and fig culture-on the Island of Majorca and in certain parts of Spain. Such publications as Culture du Figuier a Argenteuil et dans le Nord de la France, by Edmond J uignet (1909), and Fig Culture by A. C. van Velzer (1909), may be regarded as booklets rather than books, for both are decidedly restricted in content.

One printed work on this fruit is so complete and so highly regarded that it may be called a fig classic. It is The Fig, by Dr. Gustav Eisen, published as a bulletin in 1901 by the United States Department of Agriculture, Washington, D.C. This bulletin has long been out of print, and even used copies are now difficult to obtain. Another classic, upon which Dr. Eisen himself relied for much of his material, is the article by Count H. zu Solms-Laubach (1882), the translated title being The Origin, Domestication, and Distribution of the Common Fig Tree.

The book I am offering is not intended to be a textbook or a manual on practical fig culture. The reader who expects to find on its pages detailed instructions in the propagation, planting, and care of the trees, may feel disappointment as he reads it. More explicit and detailed information along these lines is available in state and federal circulars and bulletins.

Some readers may be surprised at the use of such variety names as Lob Injir (instead of Calimyrna), Dottato (instead of Kadota), and San Piero (instead of 
Brown Turkey). / have given much consideration to nomenclature, howevery and have finally chosen as most logical the names which my studies have shown to merit priority, and have then used these names

\section{Page $x$}

Gondit

$x$

The Fig

uniformly in the text. In chapter XVIII, in which marketing of California figs is discussed, I have used local variety names. In the other chapters the first mention of a commercial variety is designated by the accepted name with the synonym in parentheses, thus, Lob Injir (Calimyrna).

References to authors and articles indicate the sources of much of the information presented in this volume. I acknowledge my indebtedness to these writers and to all those who have contributed in various ways to the preparation- of the manuscript. My gratitude is tendered especially to the following friends and colleagues, who have read and criticised certain sections or chapters: Dr. I van M. Linforth, Dr. Agnes F. Morgan, Dr. H. N. Hansen, and Dr. S. W. Shear, University of California, Berkeley; Dr. E. D. Merrill, Arnold Arboretum, Cambridge, Massachusetts; Sherif Ramzey Bey, Izmir, Turkey; Mr. H. M. Reed, College Station, Texas; Messrs. Perez Simmons, Harold Hyde, Charles Taylor, Walter Reeves, J ohn Quail, and W. T. Pentzer, Fresno, California; Professor Harry S. Smith, Dr. Stanley E. Flanders, Dr. J. M. Lesley, Dr. John T. Middleton, Dr. W. B. Sinclair, and Mr. J. C. J ohnston, University of California Citrus Experiment Station, Riverside.

To my wife, Caroline Callender Condit, J am particularly and deeply grateful for inspiration and encouragement and for the long hours of patient effort she has spent in careful reading of manuscript and rearrangement of material. Without her assistance, publication would have been infinitely more difficult, if not impossible. To her and to all others who have assisted me, I again say, "I thank you."

Persuadet moris tetrum mtitare colorem

Ficus, et inuasis dat sua iura pomis. Se quoque miratur pingui grandescere succo

Et solitum gaudet uincere poma modum. Insignes foliis platanos, foelicia mensis 
Brachia, gaudentes uitis honore comas. Ingrediens pingui se cortice maxima ficus

Seruat, et optatos implet adepta sinus.

(Antoine Mizauld)

\section{Page xi}

\section{ACKNOWLEDGEMENTS}

The author gratefully acknowledges the kindness of authors and publishers for permission to reproduce material as follows:

Harvard University Press : selections from Athenaeus, The

Deipnosophists, 1927; Hesiod, Homeric Hymns and Homerica,

1915. Houghton Mifflin Company : a selection from C. C. Felton,

Greece, Ancient and Modern, 1893. G. Bell \& Sons, Ltd. : two selections from Aristophanes, The

Acharnians, 1910; and The Birds, 1930. Hutchinson \& Co., Ltd. : a selection from the Unit Library,

Horace, Satires and Epistles, 1902. The Blakiston Company : analyses from H. W. Wiley, Foods

and their Adulteration, 1917. The Clarendon Press, Oxford : a selection by A. B. Cook in

the Classical Review, 1907. J ohn Grant, Edinburgh : a selection from J ohn Smith,

Travels and Works of Captain J ohn Smith, 1910. E. D. Loveman : a verse from Verses by Robert Loveman. The Macmillan Company: a selection from J. G. Frazer,

Pausanias Description of Greece, 1913. Robert M. McBride \& Company : a selection from J an and

Cora Gordon, Two Vagabonds in Spain, 1923. George Routledge \& Sons, Ltd. : a selection from Theocritus, 
Idylls of Theocritus, 1924. W. B. Saunders Company: Analyses by James S. McLester

in Nutrition and Diet in Health and Disease, 1931. William Heinemann, Ltd., and Mrs. Frieda Lawrence:

Verse by D. H. Lawrence in his Poems.

\section{Page xii}

The Chronica Botanica Co., International Plant Science Publishers

CHRONICA BOTANICA, an International Collection of Studies in the Method and History of Biology and Agriculture, founded and edited by Frans Verdoorn, is published bimonthly at $\$ 7.50$ a year to regular subscribers (post free, foreign and domestic).

An annual volume contains about $500-600$ pages (supplemented by Biologia, cf. infra) of (1) memoirs and symposia; (2) annotated reprints of rare, classical papers; (3) directories of institutions and societies, as well as accounts of current activities in special fields; (4) Plant Science Forum: discussions, essays, articles on recent advances, biographical sketches, etc.; (5) Quotations; (d) articles and notices on international affairs; (7) a chronicle of recent events, with many unusual plates.

Of the back volumes volume 7 seq. are availabe at $\$ 7.50$ (paper) or $\$ 9.00$ (buckram), postage extra. Volumes 1-6 may still be had at $\$ 9.00$ (paper) or $\$ 10.50$ (buckram).

Binding cases may be obtained for recent volumes at $\$ 1.00$ (post free, foreign and domestic).

The following recent and forthcoming issues of Chronica Botanica are available to non-subscribers: $-8,1$, Browne: Source Book of Agric. Chemistry

(p. 290, \$5.00) 8, 2, Rafinesque: Life of Travels (p. 72, \$2.50)

8, 3, Browne: J efferson and jthe Scientific Trends

of his Time (p. 64, \$1.25)

9, 1, Jack: Biol. Field Stations of the World (p. 74,

\$2.50) 9, 5/6, Howard: Luther Burbank (p. 208, \$3.75) 10, 1, Saint-Hilaire: Voyages au Bresil et Paraguay (p. 62, \$2.00) 10, 2, Arber: Goethel's Botany (p. 64, \$2.00) 10, 3/4, Merrilleana: Selected General Writings (p. 268, \$4.00) 
10, 5/6, Wyman: Arboretums and Botanical Gardens

of North America (p. 104, \$1.50)

11, 1, Rickett: The R. Botanical Expedition to New

Spain (p. 94, \$2.50)

I'A New Series of Plant Science Books|':

9,

10,

11 ,

12,13 ,

14 ,

MacDougal: Tree Growth (out of print) Grant: Wood Pulp (out of print)

Darrah : Principles of Paleobotany (out

of print) Pfeiffer: Experimentelle Cytologic (out

of print) Ed. 1 out of print, see sub 13 for ed. 2 Guilliermond-Atkinson : The Cytoplasm

of the Plant Cell (out of print) Reed: A Short History of the Plant Sciences ( $p$. $323, \$ 5.50)$ Baldwin : Forest Tree Seed (p. 240, \$5.00) Lloyd : Carnivorous Plants (p. 352, \$6.50) Wulff: Historical Plant Geography (p.

$223, \$ 5.00)$ Schopfer-Noecker : Plants and Vitamins

(p. 300, \$4.00) Erdtman : Pollen Analysis (p. 239, \$5.00) Bawden : Plant Viruses and Virus Diseases

(out of print, third ed. in preparation) Hoagland: Inorganic Plant Nutrition ( $p$.

$226, \$ 4.00)$

15, Wodehouse: Hayfever Plants (p. 245,

$\$ 5.00)$ 
16, Verdoorn, (ed.) : Plants and Plant Science

in Latin America (p. xl + 384, \$6.00)

17, ZoBell: Marine Microbiology (p. 240,

$\$ 5.00)$

18, Wilde, Forest Soils and Forest Growth

(p. $250, \$ 5.00)$

19, Condit: The Fig (p. 222, \$5.00)

20, Kelley: Mycotrophy in Plants (in press,

ca. \$4.75)

21, Whyte et ah: Vernalization (in press,

ca. \$4.75)

22, Moldenke: Plants of the Bible (in press,

ca. \$4.75)

23, J ohansen : Plant Embryology (in press,

ca. \$6.00)

24, Dachnowski-Stokes : The Peat Resources

of the World (in press, ca. \$4.75)

25, Howes: Vegetable Gums and Resins (in

press, ca. \$4.75)

26, Knight : Dictionary of Genetics (in press,

ca. \$4.00)

Annales Cryptogamici

et Phytopathologici : 
1, Garrett: Root Disease Fungi (p. 177,

$\$ 4.50)$

2, Horsfall : Fungicides (p. 240, \$5.00)

3, Fulford : The Genus Bazzania in C. and

S. America (p. 176, \$5.00)

4, Chester : The Cereal Rusts (p. 270, \$5.00)

5, Copeland : Genera Filicum (p. 272, \$6.00)

6, Nickerson (ed.) : Biology of Pathogenic

Fungi (p. 236, \$5.00) 7/8, Frear: Catalogue of Insecticides and Fungicides (2 vols., in press, ca. $\$ 12.00$ )

Annales Bryologici, a journal devoted to the study of mosses and hepatics, of which we published (in the beginning in cooperation with Messrs. Nijhoff) 12 volumes and 4 supplementary volumes between 1927 and 1939, is now being continued by the Annales Cryptogamici et Phytopathologici (see above). Complete sets and single vols, of Annales Bryologici are still available at $\$ 4.00$ a volume. The bryological exsiccati formerly issued by Dr. Frans Verdoorn: Bryophyta Arduennae Exsiccata (dec. 1-5, 1927/29), Hepaticae Selectae et Criticae (11 series, 1930/39) and Musci Selecti et Critici (7 series, 1934/40), have all been sold out.

BIOLOGIA, an International Bimonthly Biological Newsletter, was established in J anuary 1947 to fill the need for a small and informal, though not popular, report on progress in international relations, congresses, societies, publications, and related activities in the pure and applied plant and animal sciences. Annual subscription: $\$ 1.00$ (post free, foreign and domestic), or $\$ 4.00$ for one vol. (4 years), free to all Chronica Botanica subscribers (cf. supra). Binding cases will be available shortly at $\$ 1.50$ (for one vol. with index: 4 years, post free). A sample copy of this unique scientific newspaper will be sent on request.

The Chronica Botanica Co., Waltham, Massachusetts, U.S.A.

Established in Leyden, Zuid-Holland, in 1933 Cables: Flora, Waltham, Mass., U.S.A.

\section{Title Page}


The

fig

by

Ira J. Condit, Ph.D.

Associate Professor of Subtropical Horticulture, University of California Citrus Experiment Station, Riverside

Foreword by

Walter T. Swingle, Sc.d.

Collaborator, U. 6". Dept. of Agriculture, and Consultant in Tropical Botany, University of Miami, Coral Gables, Florida

1947

WALTHAM, MASS., U.S.A.

Published by the Chronica Botanica Co.

Table of Contents

\section{Page xifi}

\section{CONTENTS}

Chapter I

THE FIG IN SONG AND STORY: The fig, a sacred tree The fig in Bible times Sycophant The fig, an emblem of fertility; its phallic significance The fig in literature Fig Sunday....................1

Chapter II

HISTORY AND DISTRIBUTION: Etymology Fossil figs Original habitat Ancient distribution Later distribution The fig in the New World History of fig culture in California Introduction of the blastophaga into California 9 
Chapter III

SYSTEMATIC BOTANY: Related species Evolution and probable origin of the fig. : 18

Chapter IV

GENERAL BOTANY: Latex Roots Wood and bark Burrknots Nodal swellings Buds Growth Crops Season Fruitfulness The leaf : form and size ; sinuses and margins; color; surface and texture; petiole; cystoliths Par-thenocarpy Teratology..............25

Chapter V

GAPRIFICATION: Historical account The blastophaga The profichi The mammoni The mamme Life history The practice of caprification Picking caprifigs Containers Artificial pollination Effects of caprification A messmate

\section{AND OTHER ENEMIES OF BLASTOPHAGA----STANDARDIZATION OF CAPRIFIGS 42}

Chapter VI

FIG BREEDI NG: Natural seedlings Seedlings of miscellaneous PARENTAGE PREVIOUS WORK IN FIG BREEDI NG THE MASLIN

seedling fig orchard flg breeding in california methods used in fig breeding Inter-specific crosses Chimeras .... 51

Chapter VII

FRUIT CHARACTERS: Collection of fig varieties Classification of varieties Color Form Size Neck Stalk Ribs Ostiole and eye Eye scales I ris Skin Bloom Flecks Hairs Meat and pulp Flavor and quality Variety keys .58

\section{Page xiv}

Condit

xiv

The Fig

Chapter VIII 
FIG VARIETIES: Varieties of the caprifig type Varieties of the Smyrna type Varieties of the San Pedro type Varieties of the common type Selected list of figs.........68

\section{Chapter IX}

SOME FIG DISTRICTS OF THE OLD WORLD: Turkey

Italy Greece Algeria Spain Portugal ; Other Mediterranean fig districts. .81

Chapter X

OTHER FIG DISTRICTS: Russia Asia Africa Australia Great Britain Central and South America Northern United States Southern United States Texas and certain western states California .94

Chapter XI

CLIMATOLOGY: Frost Methods of protection from frost Heat Rainfall Humidity and wind......103

Chapter XI I

PROPAGATION: Seeds Layers Stocks Cuttings Budding Grafting 109

Chapter XIII

FIG CULTURE:Altitude Soils Spacing Planting

Intercrops Pruning (Adriatic and Mission trees Lob Injir

trees---dottato trees san plero and brunswick trees capri-

fig trees Special pruning practices)I rrigation Fertilization Tillage Specialized fig culture.........114

Chapter XIV

THE FRESH FIG CROP: Yields Picking Packing and shipping Cold storage Freezing Oleification Eating fresh figs...................124

Chapter XV

THE DRIED FIG CROP: Production Harvesting Sun-drying Dipping and sulfuring Artificial drying Sorting and grading Storage Bleaching Processing 
Chapter XVI

FIG PRODUCTS: Preserving Candying Canning Syrup J am Paste Coffee Alcohol Beverages New-tons and bars Oil Other products. 141

\section{Page XV}

The Fig xv Contents

Chapter XVII CHEMISTRY AND FOOD VALUE: Proximate composition Analyses of fresh figs Analyses of dried figs Enzymes

Laxative properties Medicinal properties Food value Vitamins Figs for stock food............148

Chapter XVIII

ECONOMICS AND MARKETING: Statistics Prices Inspection Tariff Marketing Fig institutes California Fig Institute Fig contract Canning figs.......156

\section{Chapter XIX}

DISEASES: Root diseases Trunk and branch diseases : bacteriosis; blights,* cankers,* die-back; stilbum disease; decline

Leaf diseases : spots and blotches ; rust ; mosaic Fruit diseases : dropping; splitting; smut; souring; endosepsis; black spot; fruit rots.

\section{Chapter XX}

INSECTS AND OTHER PESTS: Pests other than insects : nematodes; mites; birds; gophers Insect pests of the tree: coleopterous BORERS,* LEPIDOPTEROUS BORERS; SCALE INSECTS; MEALY BUGS;

leaf feeders---fresh-fruit insects * fruit flies ; coleopterous fruit pests ; lepidopterous fruit pests j miscellaneous fruit pests; thrips Dried-fruit insects: control. 177

Bibliography. 188

Index 
List of Text Illustrations $x v i$

List of Tables. .$x v i$

Notes on the Vignettes. xviii

$1 \%$

Table of I llustrations

\section{Page xvi}

\section{LIST OF TEXT ILLUSTRATIONS}

Picking figs in ancient Egypt xviii

Figure 1. Amulets expressive of "fico". 6

Figure 2. Leaf forms of fig seedlings. .22

Figure 3. Deformed figs with misplaced scales. .23

Figure 4. Cross section of a bark tuber. .27

Figure 5. Nodal swellings characteristic of certain varieties of the fig, as compared

to a branch without such swellings. 28

Figure 6. Leaf types. 32

Figure 7. Fig leaf on a leaf-measuring card. .33

Figure 8. Unicellular attenuate hairs and multicellular capitate hairs from the surface of fig leaves and fruit..................34

Figure 9. A lithocyst, an enlarged epidermal cell containing a stalked cystolith 35 Figure 10. The Dottato and San Piero, showing two syconia in the axil of a leaf 37 Figure 11. Long-styled flower of edible fig and short-styled flower of caprifig . 38

Figure 12. Diagrammatic section of a syconium..........39

Figure 13. Blastophaga psenes 
Figure 14. Chart portraying the duration of crops of the caprifig tree and the emergence periods of the blastophaga. 45

Figure 15. Chart illustrating the total number of caprifigs and baskets to be used

for medium caprification of Lob Injir trees .47

Figure 16. Female Philotrypesis on the surface of a fig.....

Figure 17. Female Philotrypesis in the process of forcing her ovipositor into a fig

receptacle. 49

Figure 18. Fig chimeras 56

Figure 19. Forms of fig fruits 60

Figure 20. Forms of fruit stalks 61

Figure 21. Three figs illustrating the Spanish proverb about a luscious fig: a neck

for the hangman, a robe for the beggar, a tear for the penitent.....64

Figure 22. Map of the Smyrna fig district............82

Figure 23. Commercial fig districts of Italy............84

Figure 24. Commercial fig districts of Spain and Portugal........88

Figure 25. The commercial fig districts of California.........100

Figure 26. Blank form used by fig inspectors in California........158

Figure 27. Variety production trends of California merchantable dried figs, 1937-1944 ...."..... 164

Bis

ppppp piippl

Table of Tables 


\section{Page xvii}

\section{LIST OF TABLES}

Table 1. Names of crops of edible figs. 30

Table 2. Names of the caprifig and its crop............ 31

Table 3. Description form for fresh figs 67

Table 4. Production of dried figs in Mediterranean countries . . . . . . 81

Table 5. Interstate shipments of California fresh figs by counties in car lots . 127

Table 6. Size grades of California dried figs............ 137

Table 7. Size-grade record of California dried figs, 1929-1935 inclusive . . . 137

Table 8. Composition of fresh figs.............. 148

Table 9. Composition of dried figs............... 150

Table 10. Ash analyses of figs............... 150

Table 11. United States import duties on figs, 1790-1909....... 160

Table 12. California dried fig report; averages for crop years 1937-1944 . . . 165

$\mathrm{mm}$

M

Document Body

\section{Page xviii}

Picking figs in ancient Egypt (scene on west wall of grave No. 2, Beni-Hassan, 12th Dynasty, 2500-2400 B.C., adapted from Rosellini, 1932/44: I Monumenti dell 'Egitto e della Nubia 1:381, PL 39, Fig. 2). The Vignette on page xi shows an Egyptian peasant offering to the sycomore (originally drawn by FaucherGudin from a scene in the tomb of Zeserkereseneb, cf. Scheil (Mem. Mission 
frang., vol. 5, part 4, plate 4, wall C, top row). The sacred sycomore here stands at the end of a field of corn, and would seem to extend its protection to the harvest (redrawn from Masperol 's Dawn of Civilization: Egypt and Chaldaea, 1922). The Vignette on page xvii has been reproduced from the same source, it shows an Egyptian man and wife seated in front of the sacred sycomore fig and receiving the bread and water of the next world. The Vignette of fresh figs in boxes, ready for shipment, on page $x v$ has been drawn by Mrs. L. Koteles, the Vignettes on page xvi of a wooden tray, with an egg-cell filler of card board, and on page 207 by Mr. Gordon W. Dillon. The latter makes us acquainted with "Fig Tree J ohn," an Indian of local fame, who built his cabin beside a fig tree near the shore of the Salton Sea in California. The Vignette on page 222 shows how straw mats filled with figs are flattened in a wooden press at Coin, Spain.

\section{Page 1}

\section{Chapter I}

\section{THE FIG IN SONG AND STORY}

Although the culture of the fig for its edible fruit is a comparatively modern development, the tree was, through countless millennia, gradually evolving from a wild plant to a cultivated fruit tree. During this long period there arose numerous legends concerning the origin, usefulness, and special properties of the fig tree and its fruit, many of which have been preserved for us in ancient and even in modern literature. And though we smile indulgently at the superstitions of our early ancestors, we may find in these myths an interesting background for modern scientific and practical data.

According to one such legend narrated by Karl Boetticher (1856), Sykeus and his mother, Ge, were pursued by Zeus in the war of the Titans; she, in order to save her son, metamorphosed him into a fig tree. The city of Sykea in Cilicia owes its name to this legend. Another tradition credits the discovery of the fig to Dionysus** An Athenian legend, however, says it was the goddess Demeter who first revealed to mortals the fruit of autumn, which they called the fig. This she did as a reward to King Phytalus for receiving her into his house. Later a fig tree stood by the grave of Phytalus on the Sacred Way from Athens to Eleusis, and the whole place, a suburb of Athens*, was called "Holy Fig Tree." The historian Pausanias traveling through Greece between A. D. 160 and 180, recorded this epitaph on the tomb:

Here the lordly hero Phytalus once received the august

Demeter, when she first revealed the autumnal fruit

Which the race of mortals names the sacred fig; 
Since when the race of Phytalus received honours that wax not old.

(From J. G. Frazer, 1913.)

Ancient reverence for the fig is indicated by the belief that a priestess could tame and lead to the sacrificial altar any bull, no matter how wild, simply by tying a branch of the wild fig about his neck. The opinion of some people that the fig tree, like the laurel, possessed the power of averting lightning, is based on the myth that Ge took her son, as he was struck by the lightning of Zeus, into her castle, and caused a fig tree to spring up in which he could live again. (See A. B. Cook, 1914.) Though the fig tree may seldom be struck by lightning, the sacred Ruminal fig tree in Rome was so struck and was therefore doubly revered because lightning was believed to purify every object it touched.

Both the name and the origin of Rome are associated by Ettore Pais (1906) with the ficus Ruminalis. G. D. Hadzsits (1936) points out that this sacred tree was originally named.after Rumina, a goddess who watched over suckling animals and to whom offerings of milk, not wine, were made. The cult of Rumina was associated with the earliest life on Palatine Hill, and so it was only natural that a fig tree, having milky juice, should be

\section{Page 2}

Condit

2

The Fig

planted there. The second Ruminal fig tree in the Comitium, almost as famous and sacred as that on the Palatine, was thought to be derived from the latter. The city of Tarentum was reportedly founded where the salt waves prevented all trees except the fig tree from bearing fruit.

Another interesting legend given in somewhat different forms by Richard Folkard (1884) and by A. B. Cook (1914) indicates the prolific nature of the tree. Calchas, returning from Troy, fell in with a better seer than himself. Resting under a wild fig tree, he asked the other, Mopsus, how many figs there were on the tree. Mopsus replied: "Ten thousand except one, and a single vessel will contain them all." When the figs were gathered, this proved correct. Calchas was so mortified over this that he pined away and died.

It was predicted by a Greek oracle that the Messenians would be abandoned by heaven in their struggles with the Spartans whenever a goat (tragos) should drink the water of the Neda. All goats were therefore driven from the 
country. It happened that the wild fig, also called tragos, grew in Greece. One such tree on the bank of the Neda dipped its branches into the water, and a tragos (goat fig) having drunk the water, the Messenians were soon after defeated. (See Folkard, 1884.)

The Fig, a Sacred Tree:The Romans regarded Bacchus as the. god who introduced the fig to mankind. Hence the tree was sacred, and images of the god were often crowned with fig leaves. The first figs of the season were offered to Bacchus, and at festivals in his honor female votaries wore garlands of dried figs. The fig was carried next to the vine in processions at Rome, and Bacchus was supposed to have derived his corpulence from eating figs.

Fig-tree worship, according to J ohn F. Hewitt (1907), is credited to the people of an ancient race whose birthplace was in the country of Mt. Ararat, and who were the first Phrygian worshippers of household fire. It was preceded by the worship of the oak tree and of the almond tree. The fig tree was held sacred in all countries of southwestern Asia, and in Egypt, Greece, and Italy.

In Latium, female slaves were, on J uly 7, given special liberties. They dressed as free women, feasted under a wild fig tree, beat each other with fig-tree rods, and made offerings of the milky fig juice to J uno Caprotina, goddess of the wild fig tree. (See J. G. Frazer, 1920.)

Sacred images were often made of fig-tree wood. Theocritus, in one of his epigrams, wrote:

Goatherd, if thou the oak-set winding path Wilt follow, thou shalt find a figwood statue, New wrought, unbarked, obscene, earless.

(Translation by J. H. Hallard, 1924.)

In ancient Greece, as J ane Harrison (1908) relates, one of the harvest festivals, designated Thargelia and held in late May and early J une, was mainly a festival for the offering of the first fruits of the season. Two men known as Pharmakoi, with strings of figs about their necks, were led out in a ceremony of purification for the city. According to some

\section{Page 3}

\section{Chapter I}


authorities, the two were put to death; others state that they were driven out of the city with fig-tree rods instead of being slain. The beating was expulsive: it expelled evil, since many of the ancients believed that evil of all kinds was a physical infection and could be caught or transferred. The Pharmakoi were given cheese, a barley cake, and figs black figs as symbols for men and white figs as symbols for women. One of the objects of the ceremony was to promote the success of fig-tree caprification, practiced in Greece since very ancient times.

In the Greek festival of Plynteria, the image of Pallas was carried in a procession, for cleansing in the sea. The leading marchers carried cakes of dried figs called Hegetaria (from the Greek, hegetor, a leader), because the fig led the way in the matter of diet.

The Fig in Bible Times: Numerous references to the fig are found in the Bible. In Genesis 3: 7 we read that Adam and Eve "sewed fig leaves together, and made themselves aprons." The identity of these leaves has been the basis of much discussion, since the word "fig" may be and is commonly used for any one of several distinct species of the genus Ficus. The leaves mentioned in Genesis therefore did not necessarily come from a tree of Ficus carica. In these lines from Paradise Lost, J ohn Milton definitely referred to the banyan, either Ficus bengalensis or F. indica:

Those leaves they gathered, broad as Amazonian targe,

Both together went, into the thickest wood, where soon they chose

The fig tree, not that kind for fruit renowned,

But such as at this day, to Indians known

In Malabar of Deccan spreads her arms,

Branching so broad and long that in the ground

The bended twigs take root and daughters grow about the mother tree.

J ohn Smith (1877) believed the evidence was insufficient to prove that the leaves referred to in Genesis were from the common fig tree. On the other hand, G. E. Post (1902), a botanist of Syria and Palestine, stated there is no good reason to doubt that the leaves which Adam and Eve reportedly used to make aprons were from the common fig. In the face of such contradictory statements, one is inclined to believe that the reference is to some species of Ficus other than F. carica, the thin, rough leaves of which do not seem suitable for sewing together into aprons. W. R. Paton (1907) suggested that the story of Adam and Eve and their aprons is reminiscent of an ancient custom of fertilizing fig trees by a pair of human scapegoats who, like the 
victims of the Thargelia, associated themselves with the tree by wearing its foliage or fruit.

A number of other Bible references bear witness to the high esteem of the J ews for the tree and its fruit. When the spies came back from the land of Canaan, they "brought of the pomegranates and of the figs" as well as of the grapes (Numbers 13: 23). In Deuteronomy 8: 8, Jehovah is reported to be bringing the Israelites into a good land, "a land of wheat, and barley, and vines, and fig trees, and pomegranates; a land of oil olive and honey." The importance of figs and grapes for food may be judged from the account of Abigail, who went out to meet David with an offering of "an hundred clusters of raisins, and two hundred cakes of

\section{Page 4}

\section{Gondit}

4

The Fig

figs" (1 Samuel 25:18). Reference to the fig tree as a symbol of peace and contentment is made in various books, one in Micah 4:4 reading as follows : "But they shall sit every man under his vine and under his fig tree; and none shall make them afraid." In Palestine, as in other countries with a similar climate, some fig trees bear a first crop in J une. It may be this crop which is referred to in Nahum 3:12: "All thy strong holds shall be like fig trees with the first-ripe figs: if they be shaken, they shall even fall into the mouth of the eater."

Two parables in the New Testament may be commented on here. One is in Matthew 21 beginning with the 18th verse: "Now in the morning as he returned to the city, he hungered. And when he saw a fig tree in the way, he came to it, and found nothing thereon, but leaves only." Laying aside the moral or religious significance of the whole parable as explained by various authors, there is nothing strange in the fact that a fig tree should be found with "leaves only." Some varieties of figs never produce a first crop of fruit in the spring of the year. Mark 11:13 amplifies the statement as follows: "the time of figs was not yet." The other parable is found in Luke 13:6-8: "A certain man had a fig tree planted in his vineyard ; and he came and sought fruit thereon, and found none. Then he said unto the dresser of his vineyard, I'Behold, these three years I come seeking fruit on this fig tree, and find none: cut it down; why cumbereth it the ground ?!' " How familiar are these words to the present-day horticulturist and how difficult it is sometimes to diagnose the failure of certain fig trees to bear fruit. Many a gardener has, like his Biblical predecessor, laid the ax to the root of the tree because the fig has turned out to be a caprifig, which does not bear edible fruit, or to be a 
kind which drops its fruit for lack of caprification.

Sycophant:The word "sycophant" is derived from the Greek sykon, "fig," and phainein, "to show." What relation is there between the original meaning, "to show the fig," and the modern definition of the word, "a false accuser, a servile flatterer"? A common but very vague explanation of the word is that during a dearth of figs in Attica, figs were stolen from trees sacred to the gods; later, certain persons revealed the figs and accused the robbers; hence the name "sycophant." Interesting references to the word are found in literature. For example Alexis wrote in his comedy The Poet:

The name, fig-shower, is not rightly used

Of scoundrels. No, the first part, fig, should be

The mark of a man both innocent and sweet.

But this sweet innocent is nowadays

Tacked onto a scoundrel, and we wonder why.

(According to Cook, 1907.)

Again, there is found this quotation from Plutarchl's De Curiositate (1896) as translated by Queen Elizabeth of England:

Of like cause thel' say were Sicophantz cold and so surnamed, For when by law hit was forbid that no man should figues gather Such as them found and brought to light bar Sicophantz name.

\section{Page 5}

\section{Chapter I}

5

In Song and Story

Samuel T. Coleridge (1884) used the word "sycophant" in its original sense, "a wretch who flatters the prevailing party by informing against his neighbors under the pretense that they are exporters of prohibited figs or fancies."

Plutarch (1914) stated that Solon allowed only olive oil to be sold abroad; therefore one cannot ignore those who say the exportation of figs was also forbidden and that the one who showed up or pointed out such exporters was called a sycophant. 
Salomon Reinach (1908) thinks the priest of the cult of Phytalides should be called "sycophant." At the close of the Eleusinian mysteries the priest probably denounced the impure and the guilty or incited the crowd to denounce them. Hence the name "sycophant," religious denunciator who presided at the mysteries of the fig, was retained in popular language, where it designated an accuser who made his accusation publicly. The cult of the fig degenerated in early times, so that the sycophant, once respected and feared, came to be a cheap charlatan; thus the modern use of the word.

The Fig, an Emblem of Fertility; its Phallic Significance:In

Oriental countries, according to Aigremont (1908), the fig is a symbol of fertility and of propagation. Among the Hellenes it was sacred to the sensuous, flabby, procreative god Dionysus, who, in order to keep his promise to Polyhymnos, placed a phallus of fig wood upon the latter 's grave and preserved the promised favor for himself. The fig tree was in the vegetable world that which the swine was in the animal world, the most pronounced symbol of procreation and of fruit-bearing. Especially was the fig sacred to Priapus, in whom the phallic characteristics appeared most pronounced; images of this god were carved from fig wood. The phallus carried at many Dionysian festivals was also of fig wood.

The fig became the tree of the phallic worshippers of India as well as of Italy where the people still use the gesture "fico," the thumb inserted between the two fingers. This prophylactic gesture, known in all Mediterranean fig districts, was once sexual in character, the thumb apparently being a symbol of the phallus. The French expression for it is "faire la figue"; the Italian, "far le fichi"; the Spanish, "hacer la higa"; the Portuguese, "dar huma figa." An early reference to this gesture is made in Dantel 's Inferno, Canto XXV, 1-3:

A la fine de le sue parole il ladro

Le mani also, con ambedue le fiche

Gridando: \'Togli, Iddio, ch*a te le squadrol\'

The words "le fiche" appear in translation as "in mockery." Shakespeare refers to the gesture in the expression "and fig me like the bragging Spaniard."

Amulets, or phallic symbols, made of ivory, bronze, porcelain, and other materials are worn in various countries. J. Leite de Vasconcellos (1925) gives an excellent account of these amulets and illustrates over threescore forms used in Portugal, Italy, and northern Europe (Fig. 1). Figs of sugar candy in the form of a phallus were once sold by peddlers at the autumn festival of a Shinto Shrine in Kyoto, Japan. (See F. S. Krauss, 1907.) 
Condit

6

The Fig

William Hone (1832) says that in the early part of the 18th century the greatest insult or sign of contempt a Frenchman could show to any one was an action described as follows: he put his thumb in his mouth, seized the nail with his teeth, then drew out his arm with a curious and significant grin. The thumb in this instance represented a fig, and the action meant, "I donl't care a fig for you," an expression which is still retained. It was called giving a man "the fico." In Lodgel 's Witl's Miserie is found a reference to this gesture: "Behold I see contempt marching forth, giving me the fico with his thumb in his mouth."

Fig. 1. Amulets expressive of "fico." (Adapted from "A Figa" by J. Leite de Vasconcellos, 1925. Figs. 23, 33, 39.)

The use of the word "fig" as an expression of contempt is well illustrated in the motto of the San Francisco Press Club, consisting of the first two lines of a verse appearing in Towneley's Mysteries (1420) :

Let the world slide, let the world go;

A fig for care, and a fig for woe!

If I canl't pay, why I can owe,

And death makes equal the high and low.

Another more pleasing use of the expression is that by Robert Love-man (192-):

*^ 4 A health unto the happy! A fig for him, who frets! It is not raining rain to me, $|t|$ 's raining violets.

An amusing illustration of the use of this phrase to express contempt may be related here. Dr. Kennicott, a Hebrew scholar at Oxford, was

\section{Page 7}


very fond of fresh figs. Noticing one ripening on the famous Pocock fig tree, he labeled it, "Dr. Kennicott|'s fig." An Oxonian wag picked the fruit and substituted the label, "A fig for Dr. Kennicott.,,

The Fig in Literature:One of the earliest references to the fig is made by the poet Archilochus, about 700 B. C, who speaks of fig culture on the Greek island of Paros. (See Gustav Eisen and others.) In the Iliad, Homer (1911) refers to the "place of the wild fig tree," while in the Odyssey he mentions the fig three times, in lines which were probably interpolated at a later date. Thus Homer tells of Ulysses) ' descent into the nether world where Tantalus was famishing:

Above, beneath, around his hapless head, Trees of all kinds delicious fruitage spread; There figs, sky-dyed, a purple hue disclose, Green looks the olive, the pomegranate glows.

(See Victor Hehn, 1888.)

Aristophanes, a Greek poet of the 5th century B. C, frequently mentioned the fig. In The Acharnians we read:

Eh, but yel're squealing bravely for the figs,

Bring out the figs here, one of you within,

For these small piggies \{referring to girls].

Will they eat them? Yah I

Worshipful Heracles! how they are gobbling now.

(Translation by B. B. Rogers, 1910.)

Modern fig growers may learn from the following lines in Aristophanesl' The Birds that pests were as common then as now:

No more shall the mite and the gall-making blight The fruit of the fig tree devour, Of thrushes one troop on their armies shall swoop, And clear them all off in an hour.

(Translation by B. B. Rogers, 1930.)

The following lines from Athenaeus who lived in the 3rd century of the Christian era, are ascribed by him to Alexis. They have a familiar ring to modern ears: 
\& II Why need we say more of those who everywhere offer figs for sale in baskets? *

They always put the tough and poor ones at the bottom but the ripe and handsome ones on top. And so the purchaser, believing what he buys \'are all good, pays the price while the dealer snaps the coin in his jaw and sells wild (capri) figs, protesting with an oath they are real figs.

(Translation by C. B. Gulick, 1927.)

Alexis thus introduces a poor Athenian woman and the condition of her store of food:

As to figs the Phrygian treat, Fit for J ovel 's own guests to eat, They; when happier moments shine, They, the Attic figs are mine.

(See C. C Felton, 1893.)

Fresh figs grown in North Africa were apparently shipped to Rome, for we find that Cato once exhibited a fig in the Roman Senate and said: "I would demand of you how long it is since this fig was gathered from the tree?" When they agreed that it was really fresh, Cato thundered:

\section{Page 8}

Gondit

8

The Fig

"Yes! it is not yet three days since this fig was gathered at Carthage. So near is Carthage to our shores." With this argument he prevailed upon the senators to begin the third Punic War. The fig is reported to have been the favorite fruit of Cleopatra, and the asp with which she ended her life was brought to her in a basket of figs.

A Spanish proverb is translated as follows: "Peel a fig for your friend, and a peach for your enemy." The second part of the proverb may refer to the ancient belief that the peach was a poisonous fruit. The fig was one of the plants used by witches, for in Ben J onsonl's Masque of Queens (1609) one of the witches says:

Yes, I haue brought (to help our vowes) Homed pop pie, Cypresse boughes, The Figg-tree wild, that growes on tombes, And iuice that from the Larchtree comes. 
Charles Dickens, in Dombey and Son, says to "train up a fig tree in the way it should go and when you are old, sit under the shade of it." Shakespeare refers to the fig in several of his plays. In Henry V., for example, we find: "Figo for thy friendship. ... It is well. . . . The fig of Spain." This is an allusion to the Spanish contortion of the fingers expressive of scorn as heretofore explained. The fig of Spain may also allude to the custom of giving poisoned figs to those who were the objects of revenge; hence the probable origin of a common prejudice against the fruit. Slingsby Bethel (1691) in The Providence of God, thus refers to the practice of offering poisoned figs: "And he that is not ignorant of their murthering doctrine and practices in case of disobedience, durst not have disobeyed for fear of a dose or a fig." In Antony and Cleopatra there is the exclamation, "O, excellent! I love long life better than figs," and also a reference to a "simple countryman that brought her figs."

Fig Sunday:In parts of England it is a common practice to serve fig pies on a certain Sunday in Lent; hence the day is known as "Fig Sunday." In some cases this is the Sunday before Easter, in commemoration of the day when J esus desired to eat figs along the road to Bethany. The day is also called "Figpie Wake." The pies, made of dried figs, sugar, treacle, and spices, are said to be rather too luscious for those who are not to the manor born. In Lancashire the practice is prevalent of eating "fig sue" on Good Friday. This is a mixture of ale, sliced figs, bread, and nutmegs boiled together and eaten hot like soup. (See Thomas Thisel-ton-Dyer, 1876, and William Fraser, 1856.)

\section{Page 9}

\section{Chapter II}

\section{HISTORY AND DISTRIBUTION}

Etymology:The names which have been applied to the fig throughout the centuries have significant relation to its origin and distribution. The Latin Ficus apparently is derived from an earlier Indian stem word such as jag, or the Hebrew feg, from which come the Italian fico, the Portuguese figo, the Spanish higo, the French figue, the German Feigen, the Dutch vijg, and the early English figge or fegge, later shortened to "fig;" In Greece the wild fig was called erineos, and the edible fig was known as sykon from which is derived "syconium," the botanical name of the fruit. The edible fig was called teena in Hebrew, tena in Aramaic, tin in Arabic, paggim in Phoenician, pagga in North Syrian, and anjir in Persian. In Italy the names applied to the wild fig are profico and caprificus, the latter coming from capra (goat) and ficus (fig), referring to the worthlessness of the fruit. The Hebrew name teena signifies the tree near which another is planted, as the fig and the caprifig. It also refers to a union of the sexes such as results from caprification. Further discussion of names is given by Paul de Lagarde (1881), Count Solms- 
Laubach (1882), and Gustav Eisen (1901).

Fossil Figs:The discovery of fossil figs in quaternary and tertiary deposits of France and I taly testifies to the ancient origin of this species. Gustave Planchon (1864) and Gaston Saporta (1873) found hollow impressions of the fruit and from them made plaster casts. Saporta stated that the fig, which must have existed in great abundance, was remarkable for its small size and shape and that it resembled the fig cultivated today. R. W. Chaney, of the University of California, states: "I have seen a leaf of the carica type from the Miocene of southern California and have no doubt that its relationship to F. carica is extremely close." (Personal letter dated November 24, 1943.)

Original Habitat:The fig tree was probably first cultivated in the fertile part of southern Arabia, where wild specimens, such as those reported in 1923 by C. M. Doughty, are still found. Fig trees gradually became established in a very extensive region of western Asia including Mesopotamia, Anatolia, Transcaucasia, Armenia, Persia, and Afghanistan. The introduction of the fig into some of these countries, notably Anatolia, was followed by the gradual selection of good varieties and by their culture on a large scale. The Greek geographer Strabo, who attended school near the present town of Aidin, the center of the Smyrna fig district, reported that the figs were in his day highly esteemed and brought the highest price in the market. According to W. T. Swingle (1908), "this record goes to show that fig culture has been the principal industry in this region for

\section{Page 10}

\section{Gondit}

10

The Fig

two millennia, the oldest fruit industry of which we have any record, for the date orchards that were the admiration of Herodotus at Palmyra and Babylon perished ages ago."

The statement of Herodotus that figs were not known to the Assyrians is questioned by Erich Leick (1924), who refers to a Babylonian hymn book of about 2000 B. C. in which occur the words: "Sweeter than grapes or figs." The fig was also mentioned by King Urukagina, 2900 B. C, during early Sumerian times, its medicinal use being stressed. \{See Bruno Meissner, 19201925.) According to E. Bona via (1894), the fig is easily distinguished on Assyrian monuments by its leaves and its flat, pear-shaped fruits. In La yard I's drawings of Nineveh, fig trees are shown, some with digitate and others with palmate leaves. 
Ancient Distribution:First migrations of the fig westward from Asia undoubtedly took place in the form of dried fruit carried by man from one settlement to another. Seeds in the droppings of birds also account for the wide dissemination of seedlings throughout most fig-growing districts. Along the Mediterranean shores, where the ancient centers of commerce were located, the distribution of the fig can be more definitely traced.

Illustrations of tree and fruit of the fig are found on monuments and tombs of ancient Egypt. The frontispiece of this volume is a copy of one such illustration. It represents a fig harvest and, as Ludwig Reinhardt (1910) states, lobed fig leaves are clearly recognizable. Three monkeys (Cynocephalus ursinus) are feasting on the figs and two men are harvesting the crop. Eisen (1930) regarded the figs illustrated in the frontispiece as belonging to Ficus pseudo-carica of Abyssinia, a species bearing fruit much inferior to that of F. carica.

It is generally agreed that fig culture was established in Greece as early as the 9th century B. C. C. H. Hawes (1911) reports, however, that on the island of Crete, the forerunner of Greece, the fig tree was known and cherished, as is indicated by illustrations frequently found on buildings. The golden age of Crete was from 1600 to 1500 B. C, and two or three centuries later its civilization spread to the mainland. It would be strange indeed if the fig tree were not introduced into Greece during that period or even much earlier. The fact that it was grown there is shown by the references to it in the Odyssey. Various writers state that Hesiod, who lived in the 9th century, did not mention the fig in his writings. However, in an English translation of Hesiod by Hugh G. Evelyn-White (1915), this statement appears: "Another time to go sailing is in spring when a man first sees leaves on the topmost shoot of a fig tree as large as the footprint that a crow makes." This might refer to a wild fig tree, as did Homerl's reference in the Iliad; if so, an edible fig was probably not far distant. Both Aristotle and Theophrastus were well acquainted with the fig and caprification, and references to their works will be made in later chapters. Xenophon, a pupil of Socrates, records a conversation between the latter and another student: " I'And must I raise a fig tree as I do the vines ?\' T suppose so/ said Ischomachus, I'for he who is master of the art

\section{Page 11}

\section{Chapter II}

11 History and Distribution

of raising vines, may as well raise figs.।' " (Translation by R. Bradley, 1727.) 
necessity, rich and poor alike consuming the fruit daily. I' Every inhabitant of Athens was a philosykos, which means literally "a friend of the fig," as Plato claimed to be. The Persian king Xerxes, after his defeat by the Greeks at Salamis in 480 B. C, had figs from Attica served him at every meal in order to be reminded always that he did not possess the land where this fruit grew.

The fig tree and its culture early became established in southern Italy. Eisen (1930) gives an account of a class of beads resembling in form the fig fruit, and dating from the 9th century B. C. to the first century after Christ. The similarity between the early Italian beads and those of Syria and Egypt indicates, according to Eisen, that figs were known in Italy during the 8th century B. C, almost as early as in Greece itself. It is a fact that from very ancient times fig culture was well known to the Romans who not only transplanted good varieties direct from Syria, but also selected superior seedlings found in their own country.

The principal difference in fig culture in Greece and Italy is the prevailing practice of caprification in Greece and the general lack of knowledge concerning this practice in both ancient and modern Italy. If the varieties of figs grown and the knowledge of fig culture in these two countries had sprung from the same source, it would seem that the contrasts, especially in such a matter as caprification, would not have been so marked. While the ficus, or fig, belongs to the oldest Roman tradition, the caprificus must not have been observed until later or it would surely have had its own name instead of one translated from the Greek. Tragos, or "goat," in Greek became capri in Latin.

At the time of the fall of the Roman Empire, the latter part of the 5th century, fig culture was carried on, not only around the Mediterranean shores, but also along the Atlantic coast, in Africa, and in southern France. The influence of the Moors upon extension of fig culture is well described by Eisen (1901). The Arabic invasion, following the same route as the Phoenicians seventeen centuries earlier, extended through northern Africa to Spain and Portugal, where fig culture became of even greater importance than in Italy and Greece. The Arabs considered the fig superior to any other fruit. Mohammed, the prophet, is said to have once exclaimed: "If I should wish a fruit brought to Paradise it would certainly be the fig." Arabic names for the fruit are still used in countries of the ancient caliphate. Thus, in Portugal the caprifig is known as fico de toca, the Arabic name being tokkar, while in Malta the name tokar is yet in use.

The extension of fig culture eastward into Asia came slowly, for the tree, so well adapted to arid countries, did not thrive in the humid tropics of India or of southeastern Asia. The eastern representative of the common fig is Ficus palmata, the fruits of which are edible and are marketed to some extent in the Punjab. The supposed introduction of the fig into China about A. D. 127 is questioned by Berthold Laufer (1919), who believes that it was introduced from Persia and India not earlier than the 


\section{Gondit 12 The Fig}

Tang period, A. D. 618-907. The Chinese name for the fig is translated into the phrase "a fruit without a flower." Nowhere in China has fig culture ever played an important role, although fig trees are not at all uncommon.

In other parts of Asia, fig culture extended into Persia, Afghanistan, Baluchistan, North India, and, according to E. Werth (1932), even into Turfan in Chinese Turkestan, its most northern point of migration. In this general region several species or subspecies of Ficus, all bearing edible fruit, come together, and the word "fig" found in various records does not always mean the fig of commerce. In 1882, J. L. Budd (Budd and Hansen, 1909) attended a fair at Nizhni-Novgorod and saw on display tons of dried figs from Smyrna, Persia, Turkestan, and Syria. He reported that the uncaprified figs of Turkestan were of superior quality, some coming from as far north as Bokhara. N. I. Vavilov (1931) reports a large assortment of apricots, pomegranates, and figs, which evidently penetrated into Chinese Turkestan from Asia Minor.

Later Distribution:In Palestine, seedling figs grow in fissures of the rocks from Lebanon to the Dead Sea. Carl Ritter (1866) found them in greatest profusion around J ahrut and on the hills of Bir and Sinjil. He also stated that as one went towards Samaria, tracts were so extensive that the eye could not take them all in at once. Biblical references to the fig indicate the extent of its culture in ancient times.

In Russia, the fig tree appears to be spontaneous only in the Crimea and the Caucasus. In Transcaucasia it grows to elevations of 3000 feet, often as a low shrub. According to P. Vinogradov-Nititin (1929), wild figs are found in thickets along the Black Sea Coast as well as in Kakhetia. In the peninsula of Apsheron, fig bushes are used for binding together maritime sands.

According to E. A. Bunyard (1934), there is some evidence that fig trees were first planted in England by the Romans. That the fig was growing there as early as the 13th century is indicated by the statement of Matthew Paris (quoted by Bunyard) that in the severe weather of 1257 "figs were almost all destroyed." J ohn Wright (1894) states that Archbishop Cranmer brought fig trees from I taly and planted them in the Manor House Gardens at Mitcham about 1533; these grew to be trees one foot in diameter of trunk but were destroyed in 1790. A famous fig tree in the garden at Lambeth Palace was reportedly introduced in 1525, during the reign of Henry VIII; the original tree, of the variety White Marseilles, though greatly injured by the freeze of 1813-14, reached a trunk circumference of 21 inches. J. C. Loudon (1854) visited Lambeth Palace in 1836 and found only cuttings of the original tree 
growing.

Fig seedlings are common throughout southern France, and many good varieties have long been cultivated for their fresh fruit. With some winter protection, the trees near Paris produce first-crop figs. An interesting reference to fig culture is given by Thomas J efferson, who visited Marseilles and Toulon in 1787. In his memoranda he wrote that the most delicate figs known in Europe were those growing about this district, where

\section{Page 13}

\section{Chapter II 13 History and Distribution}

they were known as "figues Marcelloises" to distinguish them from others of inferior quality. In a letter written from Paris to William Drayton, J efferson stated: "The fig and mulberry are so well known in America that nothing need be said of them. Their culture too, is by women and children and, therefore, earnestly to be desired in countries where there are slaves."

Charlemagne is reported to have tried unsuccessfully in the year 812 to acclimatize figs in the Netherlands. J ulius Wilde (1933) says it may be taken for granted that in the Disiboden cloister garden of Germany (founded in 675) fig trees were planted in large numbers about 1150, probably owing to their introduction during the Crusades. A historic fig tree at Beutelsback, Germany, near a family tomb, was said to have been planted before 1321 and to have survived until 1800 .

In the southern hemisphere, fig culture is carried on in South America, especially in Argentina and Chile, in South Africa, and in Australia. The date of introduction into South Africa is not apparent, but both Common and Smyrna-type figs are widely distributed. Attempts to introduce the blastophaga, or fig wasp, from California were made in 1902, but not until 1908 were these insects successfully colonized. The first planting of a fig tree in Tasmania is credited to Captain Bligh, for George Mackaness (1931) states that the Captain followed his usual practice and planted a number of fruit trees, such as quince, fig, and pomegranate, near the lagoon, Adventure Bay, Van Diemenl's Land, in 1792. Fig trees were growing well in Australia by 1803 , and in 1824 it was reported that both oranges and figs were fair.

The Portuguese were apparently responsible for the introduction of the fig into J apan in 1690. It did not receive much attention by the J apanese until the advent of Europeans, who stimulated small plantings for the fresh-fruit market. The common name for the fruit in J apan is I chijiku. The term togaki, meaning "foreign persimmon," is also applied to the fig.

The Fig in the New World:According to Manuel de la Puente y Olea (1900), 
who examined records in the archives of the Casa de Con-tratacion, European varieties of fig trees were first sent to the West Indies in 1520. Oviedo y Valdes, in his history published in 1526, reported that fig trees brought from Spain were already bearing excellent fruit on the Island of Espanola, evidently Hispaniola, or Haiti. In 1590 J oseph de Acosta stated that "there grows apples and peares but not abundantly; there are but few plumbs but abundance of figges, chiefly in Peru." Father Kino (see H. E. Bolton, 1936) started mission stations in Lower California as early as 1683, and by* 1711 many Castilian fruit trees, including the fig, were thriving. Miguel Venegas (1759) wrote from Mexico in 1739 that Ugarte, an experienced gardener, had brought to San Barnabe almost every kind of fruit tree growing in New Spain "so that the banks of the rivers, canals and watering places are decorated with olive trees, figs and vines." It should be emphasized here that Spanish figs are mostly of the Common type, without fertile seeds, and that the Mission Fathers brought to New Spain, not fig seeds, but cuttings or rooted plants of dis-

\section{Page 14}

\section{Condit 14 The Fig}

tinct varieties known for their good qualities. By the end of the 17th century, therefore, fig trees were growing and fruiting in all the Spanish colonies suitable to their culture.

Probably the first reference to the fig within the present limits of the United States is that of Pedro Menendez, St. Augustine, April 2, 1579: "There are beginning to be many of the fruits of Spain such as figs, pomegranates, oranges, grapes in great quantity." Captain J ohn Smith in 1629 reported:

Vines, figges and other fruits some have planted that prospered exceedingly; but their diligence about tobacco left them to be spoiled by cattell; yet they now begin to revive .... Mistress Pearce, an honest industrious woman, hath been there neere twentie yeares (1610-1629) and now returned saith shee hath a garden at J amestown, containing three or four acres; where in one yeare she hath gathered neere a hundred bushels of excellent figges. \{See John Smith, 1910.)

It may be that the fig bushes growing at the present time at Jamestown, Virginia, are suckers of the same trees from which "Mistress Pearce" picked "excellent figges" in 1629.

John Brickell (1737), writing of North Carolina, tells of two sorts of fig trees, the greater and the lesser, the first having a very large tree but small fruit, the second growing more like a bush than a tree and producing fruit considerably larger than the former. Both J ohn Bartram (1765-1766) and William Bartram (1791) ran across fig trees in their travels. The latter 
reported that some forty miles north of Mobile, Alabama, "the fig trees were large as well as their fruit, which was then ripe (August), of the shape of pears and as large, and of dark purplish colour." In 1763 a Dr. Andrew Turnbull established a colony of 1500 Greeks and Minorcans at New Smyrna, Florida, where they grew grapes, figs, and pomegranates, all familiar fruits in their native land. (According to J ames G. Forbes, 1821.)

Fig trees were commonly grown in dooryards and gardens in the southern and southeastern states in colonial times. Lucinda Orr (1871) writes that a young lady of Virginia visited the Lee Estate in 1782 and reported as follows: "We went to Stratford, walked in the garden, sat about two hours under a butifull shade tree and ate as many figs as we could." Charles A. Hoppin (1926), who wrote about the birthplace of George Washington at Wakefield, Virginia, stated that there were in 1851, in the midst of a 200-acre cornfield, a mammoth fig tree and a stone slab inscribed: "Here the 22nd of February, 1732, Washington was born." Near by wis a thicket of shrubby fig trees covering a circular space nearly 50 feet in diameter, thickly matted together, the largest being 3 inches in diameter at the base and 8 to 10 feet high. Washington I ving (1857-1860), who visited the place about 1859, found there only two or three decayed fig trees among shrubs and vines. General Washington planted fig trees at Mt. Vernon, probably cuttings from the bushes at his boyhood home. In 1830 Edith Sale visited Mt. Vernon and found some "upshoots" of the original fig tree. She stated that "a row of fig bushes stands beside the box hedge and doubtless the children after lessons would delight in their abundance." Fig bushes are still growing and bearing at all the historic places mentioned.

The history of fruit culture is necessarily linked with the activities of

\section{Page 15}

\section{Chapter II 15 History and Distribution}

nurserymen who propagated and distributed trees. One of these, Thomas Affleck, visited Washington, Mississippi, in 1842 and reported "figs now in perfection, the last certainly the greatest luxury in the fruit line I ever partook of." A year or two later he settled at Washington, six miles from Natchez, and planted an orchard of 50 fig trees. Still later, Affleck published a series of Rural Almanacs and Garden Calendars, the one for 1852 listing 15 varieties of figs.

The fig industry of Texas is based upon the production of a single variety known locally as Magnolia. The history of this fig dates back to the activities of a tree peddler who came through the coast country selling trees labeled "Magnolia/ $\backslash$ ' It soon developed that the purchasers had received not magnolia trees but fig trees, and so the name Magnolia became attached to 
the variety. In $1900 \mathrm{~J}$. C. Carpenter visited Texas and found a few Magnolia figs growing near Houston. He settled at Aldine and planted 10 acres of trees the following winter, increasing the planting later to 23 acres. His preserving business, started in 1902, was the real beginning of the commercial fig industry of Texas.

According to a letter from W. T. Pope, Honolulu, dated January 18, 1944, the first introduction of fig trees into Hawaii was made by Don Marin. His diary mentions the planting of various fruit trees, including the fig, in his garden on J anuary 11, 1813. Captain V. G. Golovnin, visiting Honolulu five and a half years later, saw the fig trees growing in the garden of Don Marin.

History of Fig Culture in California:Fig history in California has been recounted in more or less detail by others. A complete chronicle of the events leading up to the present commercial development of the industry seems therefore unnecessary. Chief among the accounts are those of E. J. Wickson (1888), Eisen (1901), G. C. Roeding (1903), W. T. Swingle (1908), G. P. Rixford (1918), H. M. Butterfield (1938), and I. J. Condit (1933).

The year 1769 is generally accepted as the date for the first planting of fig trees in California, for it was then that Franciscan missionaries under J unipero Serra established the Mission at San Diego and transplanted fruit trees from stations in Lower California. Subsequently the same fig was planted at Missions along the coast northward to Sonoma, and it therefore became known by the variety name "Mission." In 1798 J ean La Perouse made a list of the fruit trees brought on shipboard from France, which included three white figs, two Angelique, and two violet. Whether these were actually planted at Monterey is not stated. Fig trees were found by George Vancouver (1798) in the Mission garden at Santa Clara in 1792 and at Ventura in 1793. Gardens at the San Gabriel Mission in 1829 included numerous fig trees.

Near the middle of the 19th century, settlers in California and local nurserymen began to receive cuttings and rooted trees of a considerable number of fig varieties from the eastern United States and from Europe. James Stewart, of Downey, Los Angeles County, had fig trees 12 years old in 1886 and was experimenting with many different varieties. At about

\section{Page 16}

Condit

16

The Fig

the same time Messrs. Barnard and Benedict of Los Angeles wanted 200 tons 
of figs for a crystallizing process but could not find them, although they offered $\$ 50$ a ton for the figs picked and ready for delivery.

Commercial fig orchards appear to have been established in the coast counties, in the Sacramento Valley, and in the Sierra Nevada foothills even earlier than in the San J oaquin Valley. In 1876 there were 18,673 trees in Yolo County, 17,000 in Tuolumne County, and only 685 in Fresno County.

An orchard of 27 acres of White Adriatic fig trees was planted at Fresno about 1885, the first carload of dried white figs being sent east in 1889. The White Adriatic was the most widely planted variety during the two decades following 1885, but the dried product lacked the tenderness of skin and the flavor of the imported fig from Smyrna. W. A. Taylor (1898) stated that the White Adriatic "has many points of merit, but the fact that its quality when dried is inferior to that of the imported dried fruit from Smyrna has resulted in several efforts to introduce and grow the Smyrna type of fig."

The first introduction of cuttings of the true Smyrna fig into California was made in 1880 by the late G. P. Rixford, who was then business manager of the Evening Bulletin in San Francisco. Two years later another shipment of 14,000 cuttings, consisting of several varieties of the Smyrna type, was received, a large number being distributed to subscribers of the newspaper. Governor Leland Stanford cooperated in the venture and planted an allotment of cuttings on his ranch at Vina where a number of the original trees are still growing. Other introductions from Smyrna included several thousand cuttings imported by the Fancher Creek Nursery of Fresno in 1886, fifty rooted trees by the California State Board of Horticulture in 1890, and 10,000 cuttings by the United States Department of Agriculture in 1890.

Trees imported by the various agencies grew vigorously enough, but as the fruit invariably dropped when about the size of a walnut, there developed a widespread suspicion that cuttings of some worthless variety, rather than those of the true Smyrna fig, had been secured. E. W. Maslin of Loomis, therefore, raised seedlings from seeds of imported Smyrna figs and planted them on his ranch in 1887. These seedling trees thrived, but their fruit also failed to set and mature. Both in California and in Europe there was considerable controversy over the necessity for pollination, or caprification, of the Smyrna fig, although Dr. Eisen knew of the process and explained it in detail. Artificial pollination of Smyrna figs by George Roeding at Fresno in 1890 showed that caprification is not simply a superstitious practice of ignorant peasants; interest was thus stimulated in the attempt to introduce the fig wasp, or blastophaga, into California.

Introduction of the Blastophaga into California:According to Swingle (1908), the first introduction of the blastophaga was made by H. E. Van Deman, Pomologist of the United States Department of Agriculture, who in the spring of 1890 imported fig cuttings from Asia Minor. Some of these had fruits attached from which blastophagas issued for the 
Chapter II

\section{History and Distribution}

first time in the New World. In the fall of 1890, J. C. Shinn, of Niles, California, obtained from a missionary friend in Smyrna a dozen caprifigs from which some insects issued, but there were no figs ready for them to enter. Various shipments of caprifigs were received by Mr. F. Roeding, of Fresno, from Smyrna. Some received from Mexico were presumably from native species of Ficus. Albert Koebele wrote from Mexico he was convinced that each species of Ficus had its own pollinating insect, and that further attempts to colonize the caprifig from Mexico would be useless. In $1898 \mathrm{~W}$. T. Swingle was commissioned as an agricultural explorer by the United States Department of Agriculture and went to Greece. From that country he forwarded caprifigs wrapped in tinfoil. In the winter he went to Algeria and sent cuttings as well as one large caprifig tree. Finally, some mamme figs sent by Swingle reached Fresno April 6, 1899, and were placed in a tree enclosed by cheesecloth. On J une 23, there were found on the Roeding place, caprifigs from which fig wasps were emerging. Thus was the blastophaga successfully introduced into California.

This introduction naturally stimulated interest in the commercial production of the Lob Injir (Calimyrna) fig. In 1902 the Ceres Fig Lands Company promoted the Smyrna Park colony, stating in its circular: "No horticultural event since the discovery and propagation of the navel orange can compare in commercial importance to the recent establishment of Smyrna fig culture in California. Its successful introduction into the state marks a new epoch in our fruit interests and those who engage in it first will reap large profits.,, Though this opinion was justified for a time, the "large profits" were temporary. Some thirty years later these fig plantings at Ceres had deteriorated and were being removed for reasons both cultural and economic.

The history of the introduction of the blastophaga into California is not complete without mentioning the alleged establishment of the insect on a caprifig tree as early as 1865 . Swingle and Rixford (1911) reported a caprifig tree west of Modesto, belonging to a Mr. Gates, who claimed it had carried a mamme crop ever since 1868, when he purchased the place. Mr. Roeding (1910), on the other hand, ridiculed the whole idea, stating that there was absolutely no foundation for claims concerning the early establishment of blastophagas, and that he, himself, colonized the trees near Modesto with insects from Fresno. Articles by the contending parties were printed in parallel columns in the California Cultivator, December 29, 1910. The first article purports to show the existence of blastophagas in the state in 1886, or earlier. The second concludes as follows: "Is it possible as a poor despised 
worm, ant, and fly, you have resided in Stanislaus county these many years? Oh! that I could believe it." Those who may wish to pursue the matter further will find an interesting editorial entitled, "Who brought the Blastophaga?", in the Pacific Rural Press, November 30, 1907.

\section{Page 18}

\section{Chapter III}

\section{SYSTEMATIC BOTANY}

The common fig is known botanically as Ficus carica and is included in the family Moraceae. The name carica comes from Caria in Asia Minor where in ancient times there were grown excellent dried figs corresponding to Smyrna figs of the present day. Some early botanists, including Kaspar Bauhin (1623) and Giulio Pontedera (1720), considered the edible fig and the caprifig as distinct species. Bauhin used the terminology Ficus communis and F. humilis for two forms of the fig. J ohn Parkinson (1640) gave the following classification:

1) Ficus sativa sive vulgaris. The ordinary figge tree.

2) Capri ficus. The wild figge tree.

3) Ficus nigra sive praecox. The blew figge, early ripe.

4) Chamaeficus. The dwarfe figge tree.

C. Linnaeus in 1737 reduced to one species the fig and the caprifig as well as the one designated Erinosyce by Pontedera. In his first account Linnaeus placed F. carica in the class Cryptogamia, apparently overlooking the character of the flowers inside the fruit. In [(Species Plantarum" (1753), however, he transferred it to Polygamia Polyoecia, a class having polygamous flowers on the same plant or on different plants.

The genus, Ficus, which probably includes over 1000 valid species, is now divided into several subgenera. One of these, designated Eusyce, belongs to the section in which the fruits have unisexual flowers, the staminate and short-styled pistillate flowers being in one set of receptacles, the long-styled pistillate flowers alone being in another set. The receptacles are borne in the axils of leaves in contrast to those of another sub-genus in which the receptacles are borne in fascicles on the older branches. In accordance with the opinion expressed by C. Hegardt in 1744, the edible fig of F. carica can be regarded as the female form, and the caprifig as the male form of a dioecious species. W. T. Swingle (1899) discusses this dioecism of the fig. Approximately one hundred years after Linnaeus and Hegardt classified the 
fig, Guglielmo Gasparrini (1845) separated it, not only into two species but even into two genera, Ficus and Caprificus. He changed his opinion, however, after he had planted fertile fig seeds and obtained from them both the edible fig and the caprifig (Gasparrini 1854).

Giorgio Gallesio (1820) recognized the following types: Fico selvag-gio, the normal caprifig; Fico delta natura, a caprifig with only one crop a year; Fico mostro, a caprifig which matures no perfect fruit, only pollenif-erous figs; Fico mula, a fig which becomes pomologically but not botanically ripe; Fico semi-mula, a fig which, when pollinated, becomes both botanically and pomologically mature. Eisen (1896) stated that his studies and experiments were concerned principally with four classes of figs: Capri-figs, Ficus carica silvestris; Smyrna figs, F. carica smirniaca; Common figs,

\section{Page 19}

\section{Chapter III 19 Systematic Botany}

F. carica hortensis; and San Pedro figs, F. carica intermedia. He designated the Cordelia type of caprifig as F. carica relic ta and in 1901 listed a large number of I talian and French figs with a Latin terminology, as Fico dor at o, Ficus lute $a$, and so forth.

G. Celi (1907) proposed the following nomenclature: Ficus carica sylvatica, nonedible caprifigs; F. carica subsativa, reverted figs with fruit slightly or not at all edible; and F. carica sativa, common edible figs with fertile seed (slightly improved kinds) or with sterile seed (more highly improved kinds). The classification by A. Tschirch (1911), Ficus carica erinosyce, the wild fig, F. carica alpha caprificus, the caprifig, and F. carica beta domestica, the edible fig, has not been adopted by other botanists. (See also Ruggero Ravasini, 1911.)

The fruiting behavior of four types of Ficus carica is discussed in chapter IV under Parthenocarpy. Another type of fig was described by Pontedera (1720) as Erinosyce. According to Eisen (1896), profichi of this type contain male flowers as well as "gall flowers" with wasps; mammoni figs contain "perfect female flowers" and "gall flowers" with wasps. Now, however, it is recognized that all pistillate fig flowers are potentially fertile and that there is no valid distinction between "perfect female flowers" and "gall flowers" in mammoni figs. If not used for oviposi-tion by the blastophaga, any of these flowers may become pollinated and fecundated. Apparently, therefore, Erinosyce is a caprifig with normal profichi and with mammoni which have fertile seeds.

Related Species: Certain species of the sub-genus Eusyce are very similar in habit of growth, in leaf and fruit characters, and their flowers are pollinated by the same species of fig insect. Forms intermediate between the various species indicate extensive natural hybridization, a fact which helps to explain 
the diversity of opinion among systematic botanists as to nomenclature. However, the following forms have been described as more or less distinct species.

Ficus geraniifolia. This was described by F. A. W. Miquel in 1848 in Hookerl's London J ournal of Botany, page 225, from specimens collected in Persia. Solms-Laubach listed this species, with F. persica and F. johannis as synonyms. The leaves of this species are palmately cleft like those of some geraniums; fruits are small, pale green or somewhat dusky colored, and indistinctly ribbed.

Both Ficus palmata and F. serrata were described by Pehr Forskal, 1775, in Flora Aegyptiaco-Arabica, page 179. F. palmata is a bush or small tree with tomentose twigs and with leaves rotund-cordate, 3-nerved at the base; margins serrate or dentate, occasionally 3-5 lobed. The receptacles are pedunculate, subglobular to pyriform, usually tomentose, and yellowish when ripe. According to J. Mildbraed and M. Burret (1911), the three bracts at the base of the receptacle are stipitate and borne at the same place on the stalk. $F$. palmata, though generally regarded as the Indian form of $F$. carica, is widely distributed from northern India to Afghanistan, Arabia, Egypt, and Abyssinia. The small bitter fruits have little commercial value.

\section{Page 20}

Condit

20

The Fig

Ficus persica was described by Edmond Boissier in 1846 in Diagnoses Plantarum, Volume 1, fascicle 7, page 97 . In its natural habitat it is a shrub with long grayish branches, the ovate leaves having rounded or sub-cordate base and laciniate-spatulate lobes, sparingly pubescent on lower surface. Receptacles are axillary and smooth. It differs from F. carica in its smoother leaves and its long-stalked fruit. These differences appeared of such minor consequence that Solms-Laubach included F. persica under F. geraniifolia. Its habitat is southeastern Persia.

Ficus pseudo-carica was described in 1848 by Miquel in the London J ournal of Botany, page 225. This species is indigenous to Eritraea and Abyssinia and was introduced into California by Dr. Franceschi. The caprifig form is of especial interest as the mamme figs have staminate flowers, the pollen of which may be used to pollinate Lob I njir (Calimyrna) brebas. Growers have shown very little interest in it since the profichi are small in size as compared to those of other varieties. The branches are slender and willowy, the leaves 
3- to 5-lobed, the fruits small and purplish black.

Ficus serrata, described by Forskal in the same reference as F. palmata, has very rough leaves, both simple and lobed specimens being found on the same tree. The fruits are very seedy and unpalatable. Leaves are used for scouring and removing rust from iron. Its habitat is from the Arabian desert to Mesopotamia and Syria. Solms-Laubach found decided differences between genuine Arabian-Sinaian F. serrata and F. carica. However, specimens collected by Hausknecht during his Armenian-Syrian travels and examined by Solms-Laubach showed some closely resembling F. serrata and others indistinguishable from the caprifig form of F. carica.

The following names were once accorded specific rank but are now regarded as subspecies or as synonyms of Ficus carica.

F. afghanistanica, F. malvastrifolia, and F. vitijolia were all described by Otto Warburg (1904), the first from Afghanistan, the others from Persia. They are probably only variant forms either of $F$. carica or of $F$. palmata.

Ficus caricoides and F. virgata were both described in 1832 by William Roxburgh in Flora Indica, volume 3, pages 529, 530. The first was grown in the Calcutta Botanic Garden and had the general appearance of F. carica except for its long slender twigs. The description of $F$. virgata was made from specimens collected from wild plants. According to E. G. Balfour (1885), F. virgata grows in waste places of Hindustan and Bengal up to an elevation of 5000 feet. The fruit is eaten by the natives. George King (1888) expressed the opinion that F. caricoides was only the cultivated form of F. virgata. He stated:

I do not see how either differs from the older species, palmata of Forskl I, except that the leaves are not so scabrid. And this is a difference that can be easily accounted for by climate ... I have no hesitation, therefore, in reducing both Roxburghl's species as well as pseudo-sycomorus of Decaisne to F. palmata Forsk. Moreover, I find no difference between the flowers of these four. And I have a strong suspicion that all may be but forms of F. carica Linn.

Ficus johannis is placed by Solms-Laubach under F. geraniifolia. Boissier (1879) described it as a plant growing among the rocks of south-

\section{Page 21}

Chapter III

21

Systematic Botany 
ern Persia, having small laciniate leaves and small velvety fruits with short stalks.

Ficus ludens, described by Miquel, from the Cape Verde Islands, appears to be merely a form of F. carica.

Ficus morijolia is a synonym of F. pseudo-sycomorus which equals F. palmata.

Ficus petitiana is, according to Solms-Laubach, indistinguishable from F. pseudo-carica, both indigenous to Abyssinia.

Ficus pseudo-sycomorus, the false sycomore fig, inhabits Sinai and the wilderness on the Egyptian side of the Red Sea. The divergence of opinion among botanists is well illustrated in accounts of this subspecies. SolmsLaubach believed that F. palmata, F. serrata, and F. pseudo-sycomorus could belong to the same species as all have the same habitat. Reno Muschler (1912), however, separates this species from F. carica as follows: .

Leaves pubescent or velvety at the lower surface.........F. carica

Leaves glabrescent-scabrous at the lower surface.....F. pseudo-sycomorus

He gives F. virgata as a synonym of the latter. Post (1932-33) treats F. pseudo-sycomorus as a distinct species, but Index Kewensis regards it as a synonym of F. palmata.

Otto Warburg (1904) published the following key to the genus Ficus, section Eusyce, series Carica. This key is reproduced by M. G. Popov (1929) in his recent study of the wild fruit trees of Asia Minor.

A Leaves not at all lobed or with only single lobes

Leaves glabrous below. South Arabia, Abyssinia, Somaliland ...F. palmata Leaves pubescent below

Receptacles spherical, not at all or only slightly attenuate. Baluchistan,

N. W. India F. virgata

Receptacles pyriform, decidedly attenuate. N. Arabia, Syria, Kurdistan,

Persia, and now wild in all Mediterranean countries.......F. carica

B Leaves twice dissected or at least the middle lobe incised-dentate Receptacles almost spherical 
Receptacles short-stalked (up to $2 \mathrm{~mm}$ ); lobes of the leaf acute.

Afghanistan F. afghanistanica

Receptacles with longer stalks (5-7 mm ) ; lobes of the leaf obtuse or

rounded. South Persia F. persica

Receptacles pyriform or at least strongly constricted at the base Leaves very much dissected

Receptacles broad pyriform, hardly attenuate, shortly pubescent.

South Persia F. geraniifolia

Receptacles narrowly pyriform, long attenuate, glabrous. West

Persia F. malvastrifolia

Leaves only slightly dissected; receptacles pyriform

Receptacles moderately long-stalked, decidedly attenuate, only slightly

pubescent. South Persia F. johannis

Receptacles long-stalked, very slightly attenuate; pubescence prominent. South Persia .F. vitifolia

Warburg constructed the above key from herbarium material which he admitted was limited in quantity. He expressed his belief that it would be impossible to straighten out the identity and nomenclature of these related species unless one personally secured the necessary specimens in the field. His classification of Ficus palmata in a section with "leaves

\section{Page 22}

Condit

22

The Fig

glabrous below" does not conform to that given by King, who states that leaves of this species are tomentose below. 
Plants from fig seeds recently collected in I ran and Afghanistan by Walter Koelz, Plant Explorer of the United States Department of Agriculture, are now growing in California. Leaves of these seedlings show wide variation, ranging from specimens not at all lobed or only shallowly lobed to those deeply dissected as portrayed in figure 2. Practically all leaf gradations between these two extremes can be found.

Fig. 2. Leaf forms of fig seedlings.

Warburg constructed also the following key to distinguish the forms of Ficus carica found in the Near East. This corresponds closely to the descriptions of the same forms given by Boissier (1879).

\section{Page 23}

Chapter III

23

Systematic Botany

A Leaves not lobed or 3- to 5-lobed, segments broad at the base

Leaves densely pubescent beneath. Kurdistan .................var. kurdica

Leaves at maturity sparsely villous or even glabrous beneath Receptacles pyriform

Leaves very rough on both sides, scarcely longer than broad, very obtuse Receptacles with very short stalk (2-3 mm). Sinai

var. pseudo-sycomorus Receptacles with elongated stalk ( $1 \mathrm{~cm}$. or more). Persia

var. iranica Leaves only slightly rough beneath, decidedly longer than broad, often slightly acute

Receptacles pubescent. North Syria var. rupestris

Receptacles glabrous. Widely distributed in Near East, mostly as cultivated plants var. genuina

Receptacles spherical, without neck. North Syria var. globosa 
B Leaves deeply 5- to 7-lobed, segments narrowed at the base, spatulate. North Syria var. riparum

According to this key some cultivated figs with leaves having 3 to 5 broad lobes would fall into the section genuina; most varieties having 5 - to 7-lobed leaves, as illustrated in figure 6, would come under the section riparum.

Ten subvarieties of wild fig trees of Asia Minor are described and a typical leaf of each illustrated by Popov (1929). Most if not all of these leaf forms can be found in any large collection of fig varieties. Variations in forms of fig leaves are so numerous that names and illustrations of sub-varieties could be continued almost indefinitely.

Fig. 3. Deformed figs with misplaced scales help to show that the fig fruit is a shortened, fleshy branch composed of a series of fused in-ternodes, the scales or reduced leaves of which remain intact.

Evolution and Probable Origin of the Fig:Morphologically the fig fruit is a shortened, fleshy branch, each scale within the eye of the fig representing a specialized joint or internode of the fruit branch. O. F. Cook

\section{Page 24}

Condit

24

The Fig

(1922) points out that "the fleshy wall of the fruit evidently represents a series of internode elements standing side by side and completely fused, though the scales remain distinct." Abnormal figs with misplaced scales (fig. 3) serve to emphasize this peculiar structure of the fruit.

The receptacles, or fruits, common to all species of the genus Ficus, must have evolved from other more primitive and simpler forms. In the mulberry both pistillate and staminate catkins have the flowers borne on the outside of a convex receptacle. In Dorstenia contrayerva the pistillate and staminate flowers are scattered over the surface of a flat receptacle. In Trymatococcus the flat receptacle has one central pistillate flower surrounded by numerous staminate flowers. Other forms have concave receptacles, and in Dorstenia cuspidata the receptacle is flask-like with the apex open. In fruits of Ficus, the flowers are borne on the inside of a hollow receptacle more or less closed at the apex by scales. Pollination in the primitive ancestral forms was probably brought about by wind currents. Pollination in figs is accomplished by an insect which passes its early life history inside the ovary of a fig flower. 
Just when and how this symbiotic relationship arose between the fig and the insect will probably always remain a matter for conjecture. L. Buscalioni and G. Grandi (1936) have discussed the evolution of the fig in relation to Blastophaga. Of the four types of fruits in Ficus carica the caprifig is regarded as the most primitive, both staminate and pistillate flowers being found in the same receptacle. The most highly developed type of fig is the Common type; all the flowers are pistillate and the fruits are completely parthenocarpic in all crops of the tree.

Regarding the probable origin of the common fig, Louis Trabut (1922) believed it logical to assume that Ficus carica, like many of our other fruitbearing plants, may be derived not only from one wild species but from several. In southwestern Persia there are found in close proximity various species or subspecies other than F. carica, such as F. per ska, F. vir-gata, and F. johannis. Similar associations are found in Mesopotamia and Arabia. As stated previously, natural hybridization occurs between all these species, the resulting seedlings being exceedingly variable. Trabut hoped to be able to remake this synthetic species by bringing together all the related forms and by allowing them to interpollinate. He was able, however, to secure only F. palmata and F. pseudo-carica. In California as in Algeria these two species have long been acclimatized and are being utilized in certain lines of plant breeding.

\section{Page 25}

\section{Chapter IV}

\section{GENERAL BOTANY}

The general botany of the fig will be treated under the following headings: Latex, The Tree, The Leaf, The Fruit. Condit (1932, 1938, 1941c) has discussed these subjects in detail elsewhere. See also Gug-lielmo Gasparrini (1845), Solms-Laubach (1882, 1885), Eisen (1896, 1901), M. Leclerc du Sablon (1908), and Biagio Longo (1909).

\section{LATEX}

Latex cells, or tubes, characteristic of certain families of plants, are single cells, the growing tips of which make their way through the plant tissues much as the hyphae of a parasitic fungus penetrate between the cells of a plant. Found in most parts of the fig plant, these cells are chiefly remarkable for their number; numerous minute granules colored intensely yellow by iodine are suspended in the milky contents. "Fig coffee,, may be recognized in adulterations by the striking appearance of these latex cells. Healthy fig trees show a copious exudation from the bark, but frost or drought may injure the latex cells. Since some species of Ficus have been used for the production of rubber, it is not strange that the possibilities of utilizing the 
latex of F. carica have been considered. The fig and many other latexproducing plants are not being used as sources of rubber, however, since other and cheaper sources are available.

Fig latex contains a proteolytic enzyme known as ficin, similar to that found in the mulberry, paper mulberry, and papaya. This enzyme accounts for the dermatitis often experienced by some packers of dried figs and especially by pickers and consumers of fresh figs. Hairs on leaves and fruit contribute to the irritation. (See also Chapter XVII.)

Homer, in the Iliad, refers to the wild fig-tree sap which curdles milk, a property of the latex frequently mentioned in subsequent literature. Leonardo da Vinci is said to have used the milky sap of fig branches to fix the color of paint. (See D. S. Merezhkovskii, 1931.)

\section{THE TREE}

Roots: The fig tree has a system of fibrous roots which spread considerable distances laterally and, in some soils, to a surprisingly great depth. H. P. Traub and R. H. Stansel (1930) found that a five-year-old Brunswick (Magnolia) fig tree in Texas had a root spread of 50 feet, a single lateral reaching 35 feet from the main trunk. On hardpan land in California, roots penetrate either the hole made by blasting or natural cracks in the hardpan layer and extend to a depth of 20 feet or more. While most fig roots are terrestrial, some seedlings develop temporarily as epiphytes in the crowns of other trees and between leaf sheaths of palms.

\section{Page 26}

Condit

26

The Fig

Wood and Bark: Fig wood, like willow, is soft and of comparatively little value. Horace in one of his Satires refers to a fragment of fig wood as "inutile lignum," or useless wood, and says derisively that the carpenter being unable to use it for a bench, fashions it into a god.

In days of yore our godship stood A very worthless log of wood. The joiner doubting, or to shape us, Into a stool, or a Priapus, At length resolved for reasons wise, Into a god to bid me rise.

(Translation by Philip Francis.) 
Theocritus, however, expresses a different opinion as to the value of fig wood:

And, as when a wainwright, one skilled in many an art,

Doth bend the saplings of seasoned fig tree,

Having first tempered them in the fire to make tires for the axles of his chariot,

And even then the fig tree wood is like to leap from his hands in the bending,

And spring far away at a single bound. (Translation by A. Lang, 1880.)

Theophrastus regarded fig wood as strong when set upright and as of some value in kindling a fire. In ancient folk lore, however, a man who made a great show without corresponding practice was said to be like fig-tree fuel, much smoke and little fire. In Europe, locksmiths and gunsmiths, sometimes use fig wood for rubbing and polishing since it readily takes up oil and emery. The average specific gravity is 0.43 , based on volume when green and on weight when oven dry. For comparison, the specific gravity of catalpa is 0.53 , of elm, 0.55 , of ponderosa pine, 0.42 , and of redwood, 0.40 .

Fig wood is very light in color. Annual rings are not easily distinguishable because of the uniform color of the wood. The pith of fig wood is homogeneous. Young fig stems, with the pith removed, have been used for pipe stems.

The bark of fig trees is comparatively smooth and seldom fissured. Varieties differ very little in bark characters. Bark on the trunk of Samson caprifig is, however, characteristically fissured or corrugated. Bark of Roeding No. 2 caprifig is not smooth, but scaly. Lenticels are conspicuous on young branches.

On the bark of the trunk and larger branches of most fig trees, there are found numerous excrescences, or tubers, similar to those which occur on various other plants. Such bark tubers are formed from dormant buds whose apex dies but whose base retains its vascular connection with the wood, the fibrovascular body continuing to form its own bark and new wood layers without the immediate presence of foliage (fig. 4). They are mostly spherical, and range from 2 to $20 \mathrm{~mm}$ or more in diameter. No tubers have been seen on fig branches under three years old.

Burrknots: Many species of the genus Ficus, the banyan ( $F$. bengalensis) being a good example, produce aerial roots in profusion from the trunk and large branches. It is not strange, therefore, that the common fig exhibits the same tendency under certain conditions. F. A. Wolf 


\section{Chapter IV 27 General Botany}

(1913) found on orchard trees in Alabama some "abnormal roots of figs" to which he referred as "diseased" material, but he concluded that the processes on the bark were morphologically roots, which may function as such in response to a superabundance of moisture. In California these excrescences, or burrknots, occur commonly on fig trees in humid coast climates and sparingly in dry, interior districts. Apparently, the origin of adventitious roots which appear on nodes and internodes of fig cuttings in the soil, is the same as, or similar to, that of burrknots.

Fig. 4. Cross section of a bark tuber, which is a dormant bud whose apex dies, but whose base retains its vascular connection with the wood, the fibrovascular body continuing to form its own bark and wood without the aid of foliage. (Camera lucida drawing, $\times 27$.)

Nodal Swellings: The branches of several varieties of figs show prominent lateral enlargements, or swellings, at the nodes (fig. 5). These swellings are seldom apparent during the first growing season but gradually become prominent during ensuing seasons and continue to enlarge indefinitely. They are especially prominent on Pastiliere, Sultane, and some Lob Injir

(Calimyrna) trees, but are also found on at least 12 other varieties in a California collection of 145 distinct varieties.

Buds: The fig tree is ordinarily deciduous, the length of the dormant season depending upon local climatic conditions. In some tropical countries the tree may be nearly or quite evergreen. Marcus Varro (1912 translation) reported that in the Elephantine district of Egypt neither fig trees nor vines shed their leaves. In Hawaii there is a short dormant season of three or four weeks when the trees are almost or entirely leafless. In most

\section{Page 28}

\section{Gondit}

28

The Fig

fig districts, both fruit and vegetative buds form in axils of leaves during the late summer and fall and remain on the tree during the winter. 
Dormant fruit buds are distinguishable from the vegetative buds by their large size and plump, rounded appearance. The numbers and sizes of fruit buds are closely related to the vegetative growth of the tree and to the size of the crop maturing in summer and fall. Caprifig trees, which have a very light summer and fall crop, commonly produce an enormous

Fig. 5. Nodal swellings characteristic of certain varieties of the fig, as compared to a branch without such swellings.

number of fruit buds which expand in the spring and mature a crop in J une.

Color of the fruit buds is approximately that of the terminal bud. Color of the terminal buds is largely correlated with color of fruit, most green-fruited varieties having green buds and most dark-fruited varieties having darkcolored buds. Some varieties having dark figs, such as Col de Signora Nero and Gouraud Rouge, show green terminal buds; vice versa, some with green figs, notably Genoa, have dark-colored buds. The shape of the terminal bud is, in general, conical, the tip being more or less attenuate.

\section{Page 29}

\section{Chapter IV}

29

General Botany

Odor:Various parts of the fig tree have a more or less distinctive fragrance which one can often distinguish while driving along a road bordered by leafy fig trees. G. M. Mackie (1898) says that in Palestine the opening buds of the fig tree send out a peculiar odor, like sweetly perfumed incense. Dried fig leaves have such a persistent and agreeable odor that tobacco companies sometimes use them to blend with tobacco for cigar wrappers.

Whole fresh figs seldom have a distinctive aroma. Caprifigs, however, emit a characteristic fragrance which apparently attracts the female blasto-phaga to the figs when the flowers are receptive to oviposition.

Growth: The life span of a fig tree is short when compared to that of an olive tree. Individual fig trees may continue to thrive up to 100 or more years of age, but most orchard trees decline after 50 to 75 years. H. R. Hagan (1929\&) reported that in the Meander Valley he found only one Smyrna fig orchard in which the trees were 50 to 60 years old, though usually a cycle of 35 to 40 years covers the life of any single trunk. In Italy the life of a fig orchard is from 50 to 75 years, depending upon the soil and the cultural conditions. In California the oldest fig tree is probably on the William Curtner 
place, near Mission San J ose; it was planted about 1800. The orchard planted by George Roeding near Fresno between 1888 and 1891 succumbed about 1925 to the ravages of rootknot and sunburn. An orchard planted at Merced in 1893 is still vigorous and productive and should continue so for many decades.

Fig trees are regarded as being of producing age the seventh season after planting. For purposes of estimating income tax returns and depreciation, the following basis has been suggested for the Merced I rrigation District: Adriatic, in bearing at tenth year, productive life thirty years; Mission, productive over a period of fifty years; Lob Injir, ten years to producing age, depreciation at one twentieth per year thereafter; Dottato, in bearing after the eighth year, the productive life considerably over fifteen years.

Fig trees have a habit of growth, or a system of branching, which is more or less characteristic of the variety. Adriatic, also Stanford caprifig trees, are, in general, round-topped with broad spreading branches. Lob Injir trees have a more upright habit of growth, and unless they are pruned properly, the branches often tend to droop badly. Stanford Smyrna, on the other hand, has a more compact system of branches, with little tendency to droop. Roeding No. 3 caprifig tree has a dense growth of slender branches, while Roeding No. 2 has willowy branches, upright in habit. Trees of F. palmata and of F. pseudo-carica have slender willowy branches with white pubescent twigs. Seedlings of certain crosses show dwarfing or nanic branches. Nanism, however, is not a variety character, for nanic seedlings would hardly be worth perpetuating.

Fig trees in orchard form compete with each other for root and branch space and keep to a moderate size. Individual trees in a favorable environment often reach immense proportions. One famous tree at Roscofr", France, reportedly planted about 1621, showed in 1889 a trunk 2.5 feet in

\section{Page 30}

\section{Gondit}

30

The Fig

diameter and a branch spread of 25 yards, with 35 stone pillars supporting the branches. In 1821 a tree near Marseilles had a trunk circumference of 6 feet, 9 inches. The branches of spreading fig trees sometimes droop to the ground and take root, thus forming new trunks, somewhat as the banyan does. 
The location of the largest fig tree in the world is not known at present.

Candidates for such an honor are reported from time to time, especially from Arizona and California. One fig tree reported by Condit (1919) near Corning had a trunk circumference of 13.5 feet at 3 feet from the ground surface. A still larger tree at Knight|'s Ferry had, in 1921, a trunk from 14 to 15 feet in circumference.

Crops:Varieties of the Common type of fig differ in their fruiting habits. Some, such as Mission and San Piero (Brown Turkey), bear two crops, one produced on the wood of the previous seasonl's growth and maturing in J une, the other borne mostly in the axils of leaves of the current season and maturing in August. Varieties such as Ischia White and Celeste bear only one crop, which matures in late summer. A so-called third crop sets late on some trees and matures in November, but this crop may be regarded simply as an extension of the second. In the cool climate of England seldom more than one crop matures. The Spanish name "brebas" has been largely adopted in California for first-crop figs. No distinctive name for the second crop has yet been adopted in English-speaking countries. Table 1, giving names of the various crops as found in fig-growing countries, is largely adapted from Eisen (1896).

Table 1.Names of Crops of Edible Figs:

May-J une August-October November

United States First crop Second crop Late

France Figue-fleur Figues dl 'autome

Figues ordinaire

Italy Fiori Pedagnuoli Cimaruoli

Fioroni Forniti

Palestine Bikkurim Tel'enim

Spain Brebas Higos

Portugal Figos lampos Figos vendimos

Algiers Boccore or Bakor Kermous

Sometimes late figs which do not mature in the fall remain on the tree over winter and ripen in early spring. These are called "phaggim" in Palestine. Lob Injir trees commonly carry in winter a few immature figs which may be easily mistaken for mamme caprifigs. 
The caprifig tree also produces three more or less distinct crops in the interior valleys. Italian names for these crops have been adopted generally: profichi, the J une crop; mammoni, the summer crop; and mamme, the winter crop. In some desert regions development of the various crops is hastened by high temperatures, and as many as seven more or less distinct crops of the caprifig are reported. In cool coastal climates only two may mature.

\section{Page 31}

Chapter IV

31

General Botany

Table 2, giving names of the caprifig and its crops, is also adapted from Eisen.

Table 2.Names of the Caprifig and its Crops:

NameNov.-AprilApril-J uneJ uly-Nov.

First cropSecond cropThird crop

ItalyCaprificoMammeProfichiMammoni

SpainCaprahigo

PortugalFico de toca

Asia MinorOriginosBoghadhesAshmadhes

MaltaTokar

GreeceErineosCratitiresOrniFornites

AlgeriaCaprifiguierOuahaDokkarDjeha

Season:As pointed out above, climate has a marked effect upon the number of crops a fig tree bears and upon the time of their maturity. In Hawaii the dormant season is so short that supplies of fresh local figs are on the market every month in the year. At Poona, India, the fig crop matures in March and April, and dormancy of the trees is induced by monsoon rains which begin in J une. In California, fig varieties differ considerably in season of growth and fruiting. The Adriatic tree leafs out earlier than the Lob Injir and is therefore more subject to damage from spring frosts. Trees of F. palmetto, are much 
earlier in leafing out than trees of F.carica. St. J ean and Barnissotte are early varieties of common figs; Verdal Longue and Ischia Green are late figs.

The fresh fig season begins in the Coachella Valley of California the first week in May with the ripening of San Piero figs, a week or 10 days before Mission figs mature. In the San J oaquin Valley, Mission brebas mature the second week in J une and continue until early J uly. Very few figs"are available in any district in J uly; but in August, Lob Injir, Mission, and Dottato figs from the San J oaquin Valley are plentiful in city markets. San Piero figs from southern California are on the market from early August to October. In seasons free from severe frosts, figs continue to ripen along the southern coast and in the desert valleys until Christmas or later.

Fruitfulness:Theophrastus made the general observation that copious production of leaves on a fruit tree reduces the quantity of fruit. He mentioned the fig and grape as exceptions, however, stating that these bear best in seasons of luxuriant foliage. This is apparently true of some varieties of figs, but not of others. For example, Dottato, San Piero, and Brunswick trees which are pruned heavily and develop strong vegetative growth are usually very prolific of fruit; some other varieties, such as Mission, when similarly pruned, are notably unproductive.

A. F. Barron (1868c) noted that "as a general rule the smallest varieties are the most prolific. Of these, White Ischia, Black Provence and Oeil de Perdrix bear fruit as profusely as an ordinary gooseberry." This is characteristic of both Ischia and Violette de Bordeaux in California. Some caprifig trees bear more fruits than leaves, the profichi crop being

\section{Page 32}

Condit

32

The Fig

such a drain upon the tree that little if any vegetative growth takes place until after this crop matures in June.

\section{THE LEAF}

Leaf characters are sufficiently stable in fig varieties to be of value in classification and identification. For example, Philip Miller (1768), in describing Brunswick, or Hanover, fig, stated that "the leaves are much more divided than those of most varieties.,, 
Leaves from a single tree differ considerably, juvenile fig leaves generally showing much deeper sinuses and narrower lobes than leaves on fruiting branches. H. N. Starnes and J. F. Monroe (1907) illustrate a single leaf as typical of a variety, as does N. Mauri (1939a) in his study of caprifigs. The latter, however, in his treatment of edible figs of Algeria the same year (Mauri, 1939\&), illustrates nine leaves to show the variation in a single variety.

Fig. 6. Leaf types: A, base calcarate, lobes linear; B, base cordate, five-lobed, lobes spatulate; $C$, base calcarate, lobes lyrate; D, base calcarate, lobes latate; E, base cordate, three-lobed; F, base truncate; G, base decurrent; $H$, leaf not lobed, margin crenate.

Form and Size:In his variety catalogue, Eisen (1901) briefly describes leaves of the principal fig varieties, using various descriptive terms for size, lobing, margins, and petioles. F. Vallese (1909) and Pedro Estelrich (1910) both pay some attention to leaf characters in their descriptions of fig varieties, the former including an outline sketch of two typical leaves.

\section{Page 33}

\section{Chapter IV}

\section{3}

\section{General Botany}

Alvaro Bobone (1932), in his taxonomic study of figs, neither includes leaf forms in classifying varieties nor describes the foliage of any of the 27 varieties discussed. He does state, however, that the leaves of Ficus carica are described by Pereira Coutinho (1913) as petiolate, large, roughpubescent, cordiform, 3- to 7-lobed or almost entire, sinuate-dentate. Bobone refers to Melo Leote (1900), who pointed out that leaf characters are variable, and that 3-, 5-, and 7-lobed leaves often occur simultaneously on the same tree.

Fig. 7. Fig leaf (lower surface, showing prominent venation) on a leafmeasuring card. Measurements, $L=3 S ; W=38 ; P=28 ; W x L=1330 ; \mathrm{W} / \mathrm{L}$ $=1.08 ; \mathrm{P} / \mathrm{L}=0.80$.

Fig varieties which typically have 3-lobed leaves are apparently common in Algeria, for 7 of the 18 varieties illustrated by Mauri (19396) show the leaves to be 3-lobed. Several of the single caprifig leaves illustrated by Mauri (1939a) are also 3-lobed. Three-lobed leaves prevail on trees of Constantine (fig. 6E) and Ischia (fig. 6G) in California. 
Five-lobed leaves are more or less typical of Celeste, Dottato, Pastiliere, Adriatic, and Lob I njir (fig. 6B). Seven-lobed leaves or leaves with the base spurred (fig. 6A and C) are commonly found on trees of San Piero, Brunswick, and Mission. On trees of most, if not all, of these varieties, however, the number of 5-lobed leaves is equal to or is greater than the

\section{Page 34}

Condit

34

The Fig

number of 7-lobed leaves, a fact which emphasizes the doubtful value of an illustration showing a single leaf as typical of a variety.

The following outline, partly based on that of Starnes and Monroe (1907), is suggested for use in classifying leaf types:

Leaf not lobedFicus palmata (fig. 6H) Leaf palmately lobed:

Base decurrentl schia (fig. 6G) Base truncateStanford capri (fig. 6F) Base cordate:

Three-lobedConstantine (fig. 6E)

Five-lobed, lobes spatulateLob Injir (fig. 6B) Base calcarate:

Lobes latateMission (fig. 6D)

Lobes lyrateSan Piero (fig. 6C)

Lobes lineateBrunswick (fig. 6A)

Dimensions used in determining the size of the fig leaf are as follows: width of blade, W; length of blade, L; and length of petiole, P. A leaf-measuring card, as shown in figure 7, facilitates the measurement of large numbers of leaves and the computation of average figures for W, L, and

Fig. 8. Both unicellular attenuate hairs and multicellular capitate hairs occur on the surface of fig leaves and fruit. (Camera lucida drawing, x600.)

P. Relative size can then be indicated by the product $W Y^{\wedge} L$ and the general form by the ratio W/L. According to F. T. Bioletti (1938, p. 270), "In leaf 
measurements of several hundred varieties of vinifera vines at Davis, the latter ratio [W/L] has been found always greater than $1 . "$ In leaf measurements of figs, the ratio W/L is sometimes less and sometimes greater than 1. Leaves for measuring should be selected from fruiting branches of normal trees, at least 50 specimens being collected from a single tree.

Sinuses and Margins:The leaf of the fig, like that of the grape, commonly has five main veins, each originating at the petiole and supplying a corresponding lobe. Between these lobes are the five sinusestwo upper, two lower, and the petiolar sinus. The upper and lower sinuses vary considerably and may be classified according to depth and form.

\section{Page 35}

\section{Chapter IV}

\section{5}

\section{General Botany}

None of the fig varieties studied has leaves with entire margins, although some leaves are nearly entire. In leaves of Lob Injir (fig. 6B), Adriatic, and Sultane, the lower margins of lobes are entire, and the upper margins are crenate. Leaves like those of Ficus palmata (fig. $6 \mathrm{H}$ ) have crenate margins. Many varieties, San Piero (fig. 6C) for example, have leaves with coarsely crenate margins.

Color:Leaves of cultivated fig varieties are predominantly bright green. Some varieties, such as Baalie and Marabout, show a distinctly lighter green foliage than others. The lower side of a fig leaf is invariably of a much lighter shade of green than the upper, partly because of the numerous epidermal hairs on the lower surface.

--upper epidermis

-----pafisade cells

$\sim$ C4sto Uth -fower epidermis

Fig. 9. A lithocyst is an enlarged epidermal cell containing a stalked cystolith from the core of which radiate cytoplasmic strands connecting with the cell wall. (Camera lucida drawing of a very young leaf section.)

Surface and Texture:The five main veins of a typical fig leaf are very light green, or almost white, the color contrasting sharply with the deep green of 
the general leaf surface. Leaves of such figs as Fraga, Adriatic, and Constantine have a somewhat glossy or shiny surface in comparison with the dull surface of Dottato and Lob Injir.

The epidermis on both the upper and the lower side of the leaf is studded with minute hairs, or spicules (fig. 8). On the upper surface, the hairs are stiff and widely scattered, rendering it like sandpaper to the touch; on the lower surface, the hairs are numerous and soft. As pointed out by Otto Renner (1906), there are on the lower leaf surface some capitate 3- to 4celled hairs as well as numerous unicellular hairs of various lengths.

Measurements of the longest hairs are as follows: on the upper surface, 19.9 iil \on the lower surface, 31.1 p. Capitate hairs are scarce and almost identical in shape and size with those on the surface of the fruit. Hairs on leaves and petioles of some horticultural forms of Ficus pseudo-carica and

\section{Page 36}

Condit

36

The Fig

of F. palmata are so numerous that these organs are prominently pubescent. Mature leaves of Ficus pseudo-carica and of F. palmata are fairly thin and pliable. Leaves of F. carica are comparatively thick and stiff, although among the different kinds there is considerable variation in thickness and texture. Adriatic leaves are stiff and harsh making the harvesting of the fresh fruit more difficult than the harvesting of Dottato and Lob Injir figs, both of which have more pliable leaves. Panache, Fraga, and Pastiliere commonly have rather thick and brittle leaves.

Petiole:The petioles are described by Mauri (193\%) as thick or thin, long or short, slender or stout, green, or sometimes, tinted with rose-carmine. The terms "long," "medium," and "short" have little meaning unless some standard of comparison is used. Such a standard can be, as in the study of grapes, the relation of petiole length to length of midvein. Bioletti (1938) found that in grapes, the midvalue $P / L$ ranged from 0.6 to 1.2 . In figs, the highest value found for $P / L$ was 0.75 in Marseilles, although Croisic and Marabout actually have the longest petioles, each averaging $12 \mathrm{~cm}$.

Petiole length varies considerably, leaves growing in the shade having longer petioles than those exposed to the sun. Sometimes the petioles are slightly flattened, as shown in a cross section. Thickness of the petiole can best be determined by actual measurement of the diameter about one-fourth inch back from the point of union with the twig. 
Color of petiole is apparently closely correlated with color of fruit and of terminal bud. Mission, Ischia Black, and Violette de Bordeaux have black fruit, pinkish or brown terminal buds, and pinkish petioles. Roeding No. 3 and Euscaire, which show pinkish terminal buds, have green petioles. Green is the predominant color of petiole in figs that have green or yellow fruits.

Cystoliths:Fig leaves, when sectioned, commonly show among the spongy parenchyma cells of the lower leaf surface very much enlarged epidermal cells, each containing a peculiar, stalked body covered with blunt projections. This body, or cystolith (fig. 9), is built up from the epidermal portion of the cell wall as a stalked protrusion on which are gradually deposited successive layers of calcium carbonate. The stalk itself is strongly silicified and ordinarily extends beyond the surface of the cell into a sharp nipple-like protuberance. Apparently, cystoliths are bodies of an excretory nature providing special reservoirs for the calcium carbonate that becomes superfluous in the metabolic process.

\section{THE FRUIT}

Variety descriptions of figs are largely based on fruit characters. Detailed description of these characters will be reserved for the chapter on varieties. In the following sections we will discuss Syconium, Floral Morphology, Cytology, Parthenocarpy, and Teratology.

Syconium: Pomologically speaking, the fruit of the fig is a "syconium," a name originally suggested by C. F. Mirbel (1813). "Syconium"

\section{Page 37}

\section{Chapter IV}

\section{7}

General Botany

may be defined as a collective fleshy fruit in which the ovaries are borne upon an enlarged, more or less succulent, concave or hollow receptacle. Botanically, the fruits of the fig are the one-seeded ovaries which line the inner wall of the receptacle. According to G. M. Smith et al. (1928), the fig resembles a multiple fruit but differs in that the individual fruits are not adherent. The fig is unique among fruits in having an apical orifice, or ostiole, which connects the cavity of the receptacle with the exterior.

Fig. 10. The Dottato (left) and San Piero (right) as well as many other varieties often produce two syconia in the axil of a leaf. 
Syconia of Ficus carica are borne in the axils of leaves. Those produced late in the season generally persist throughout the winter as dormant fruit buds and push out with, or sometimes slightly in advance of, the leaves. Brebas, or first-crop figs, are therefore produced on wood of the previous season. Syconia of the main crop are usually single or solitary, although in some varieties they are borne in pairs (fig. 10), one on each side of the vegetative bud.

Floral Morphology:The Chinese name for the fig signifies "a fruit without a flower." Apparently, Theophrastus also regarded the fig as a flowerless plant, as did Albertus Magnus in the 13th century. This impression is gained from the fact that the flowers are borne inside the receptacle. No mature hermaphroditic flowers have as yet been reported

\section{Page 38}

\section{Condit 38 The Fig}

in the fig. The flowers are fundamentally pistillate or staminate as the case may be, but rudimentary pistils are commonly found in staminate flowers and rudimentary stamens occasionally occur in pistillate flowers. Short-styled flowers, which are found in, and are typical of, caprifigs, are adapted to oviposition by the blastophaga.

These short-styled flowers are commonly called "gall flowers $/ \wedge$ ' but Condit and S. F. Flanders (1945) regard this term as a misnomer. The word "gall" is defined as a swelling, or excrescence, produced on a plant by some other organism. In the short-styled flower of a fig there is no ex-

Fig. 11. Left: Long-styled flower of edible fig. Right: Short-styled flower of caprifig, with egg of blastophaga; cells lining stylar canal injured by ovipositor.

crescence resulting from the presence of any stage of Blastophaga in the ovary. For such an ovary, when inhabited by B. psenes, the two authors propose the name psenocarp.

Long-styled flowers are typical of Smyrna, White San Pedro, and common figs, all of which bear edible fruit. Ordinarily, a single fig tree bears syconia with flowers either all long-styled (edible figs) or all short-styled (caprifigs) (fig. 11). I. J . Condit (1934) has described two anomalous seedling fig trees, both of which had some branches bearing long-styled flowers and some bearing short-styled flowers.

The structure and the development of flowers in Ficus carica have been discussed by Condit (1932). The flower is typically pentamerous, the perianth lobes of long-styled flowers being much shorter than the style. Leclerc du 
Sablon (1908) found a continuous series of flowers ranging from those with short styles to those with long styles. Bifid stigmas are characteristic of most fig flowers. The papillate stigmatic cells of both

\section{Page 39}

\section{Chapter IV}

39

General Botany

long- and short-styled flowers are receptive to pollen, and both types of flowers are capable of developing fertile seeds.

The ovary wall of pistillate flowers becomes sclerified during the development either of a fig-insect larva or of an embryo within the ovary. Stone cells of the sclerified wall are sufficiently characteristic to enable their identification in some food preparations, such as jam and coffee. There is a single ovule in each ovary. Normal endosperm develops as the result of pollination and fertilization in the ovule. There is also a parthenogenetic development of endosperm in short-styled flowers as the result of the presence of a blastophaga larva in the ovule, and there is sometimes a similar development in long-styled flowers without any apparent stimulus.

Staminate flowers are commonly located in a mass (fig. 12) just below

Fig. 12. Diagrammatic section of a syconium, showing short-styled pistillate flowers, immature staminate flowers, and scales lining the ostiolum.

the scales lining the ostiolar opening of the caprifig. In some caprifigs, stamens are found scattered indiscriminately among the pistillate flowers. \{See Giulio Conci, 1924.) A very pronounced dichogamy occurs in the development of caprifig flowers, the staminate flowers maturing pollen several weeks after the pistillate flowers in the same fig are receptive to pollen. For this reason self-pollination is impossible.

Pollen grains germinate readily in a 5 per cent sugar solution. $\mathrm{H}$. M. Reed and S. H. Yarnell (1940) found that pollen stored at room temperatures remained viable from 3 to 20 days; if it was held at $470 \mathrm{R}$, viability was prolonged up to 105 days. Germination of pollen grains takes place shortly after pollination of the stigmatic surface. Four days after pollination, considerable development of endosperm has occurred, and six days afterward two-celled embryos have been formed in the ovule. No pistillate flowers have been found which contain both an embryo and a blastophaga larva. The reason for this is that oviposition by the blastophaga injures the cells of the stylar canal, producing 
a toxic effect which inhibits growth of the pollen tubes.

The seeds of figs may be large, medium, or small, few or many, con-

\section{Page 40}

Condit

40

The Fig

spicuous or indistinct, Lob Injir seeds being taken as a standard for comparison. Seeds of Marseilles are unusually conspicuous, for they stand out sharply against the background of white pulp. Normal seeds are somewhat flattened, slightly pointed or protruding at the hilum, minutely pitted over the surface, and light chestnut in color.

The number of seeds found in figs is large. Rixford (1918) reports an average of 1600 fertile seeds in each of three caprified Adriatic figs. Mauri (1939\&) found from a study of 18 varieties of Kabylian figs that the average number of fertile seeds ranged from 716 to 1831 per fig, and that sterile seeds ranged from 15 to 218. Studies of eleven caprified Adriatic figs in California show that the sterile seeds averaged 986 in number and fertile seeds 1597. In sixteen Dottato figs, the average numbers were 30 and 567, and in nine Mission figs, 292 and 408, respectively. The weights of 500 sterile seeds averaged 0.225 gram, and of 500 fertile seeds, 0.451 gram.

Cytology:Cytological studies made by Condit (1928c) from root-tip material of Ficus carica, F. palmata, and F. pseudo-carica, showed the diploid chromosomes to be 26 in number. Bobone (1932) confirmed this for F. carica. Chromosome characters are not significant in differentiating fig from caprifig.

Parthenocarpy:Parthenocarpy, both stimulative and vegetative, is exhibited in various types of Ficus carica. (See Condit, 1938.) In most caprifigs, the syconia fail to set unless the pistillate flowers are stimulated by oviposition and by the larval development of the blastophaga in the ovary. Some caprifigs, such as Roeding No. 1, are partly pathenocarpic, that is, they produce "blank" figs more or less freely. Some like the Croisic are completely parthenocarpic. Among seedling caprifigs recently fruiting in California, there are found numerous individuals which are nearly or completely parthenocarpic in one or more crops.

Smyrna-type figs are completely non-parthenocarpic, the syconia maturing only after the pollination of their flowers and a resultant development of the 
ovules. Sometimes a few brebas of the Lob Injir variety develop parthenocarpically. Trees of the White San Pedro type show a very peculiar and interesting behavior as to fruit production: brebas show complete parthenocarpic development but figs of the second crop are nonparthenocarpic like Smyrna figs. Here is a case of both parthenocarpy and non-parthenocarpy on the same branch in the same growing season.

Finally, Common-type figs, such as the Mission, Dottato, and Brunswick, are completely parthenocarpic in both crops. Some figs classed as Common type are incompletely parthenocarpic. An example is Bourjas-sotte Grise, which in California valleys drops at least 90 per cent of its crop unless the figs are caprified. The factor for parthenocarpy, therefore, appears to be rather unstable or only incompletely fixed in some common figs. W. H. Chandler (1934) found at Davis that a large percentage of fruits naturally abscissed on trees of the Brunswick fig; fruit buds were forming and dropping all summer.

\section{Page 41}

Chapter IV

41

General Botany

Teratology:Teratological forms of the fig are common, more so in some varieties than in others. Gasparrini (1845) illustrated a fig constricted at the middle by a row of misplaced scales. Unusual fig flowers were figured by Caro Massalongo in 1888. V. Viviand-Morel (1890) exhibited a proliferated fig before the Botanical Society at Lyon and reviewed the observations of $A$. Moquin-Tandon (1841) on such specimens. The latter divided proliferated figs into three classes:

1) Fruits which bear foliar organs (frondipares) ;

2) Fruits which give birth to flowers (floripares) ;

3) Fruits which bear other fruits (fructipares).

Various teratological fig forms are also reviewed by O. Penzig (1922).

According to Eisen (1901), Merioun (Fico fetifero) has a very large, open eye "emitting one or more small figs similar to the mother fig. The monstrosity of this fig is similar to the one found, for instance, in roses, where the axis is prolonged, forming a new rose; or as in citrus fruits, such as the navel orange." 
Abnormal figs are shown in figure 3. Protrusion of flowers from the ostiole, as described by Penzig and Leclerc du Sablon, is commonly found in California figs.

\section{Page 42}

\section{Chapter V}

\section{CAPRIFICATION}

Historical Account: Caprification is the process by which pollen is transferred by the fig wasp, Blastophaga psenes, from the caprifig to the edible fig. From the detailed accounts of caprification and its history by Solms-Laubach, Eisen, Longo (1909), Leick (1924), and others are derived the following facts. Aristotle, about 340 B.C., told about a small creature called "psen" which pierced unripe figs and thus caused them to remain on the tree until mature. Theophrastus, a pupil of Ajristotle, gave a very clear account of caprification, but like his teacher, believed that the fig wasps nibbled at the cultivated figs and so made them swell.

For some twenty centuries following the time of Theophrastus, little was added to the store of information about the caprifig and its insect inhabitant. J. P. Tournefort (1718) even confused the fig wasps with the moths that infest dried fruits. Hegardt (1744) and J ohn Hill (1751) both explained that caprification really effects pollination and fecundation of the fig flowers.

The conclusions of three different investigators of caprification during the 19th century may be cited. The Italian horticulturist, Giorgio Galle-sio, found that there are two races of figsone which requires caprification in order to mature its fruit and one which matures fruit without this process. Fruits of the latter he designated as "mule figs" since he believed they were not susceptible to the effects of pollen. Rixford (1918), however, showed that the terms "mule figs" and "mule flowers" are erroneous and that all pistillate flowers are potentially fertile. In 1845 Guglielmo Gasparrini proved to his own satisfaction that caprification is useless and maintained that its practice ought to be abolished. An account of his experiments, with the above conclusion, was published in the Annual Report of the California State Board of Horticulture for 1891, pages 234-259. The French botanist G. A. Olivier (1801) reported, after travels in the Near East, that it was the first crop of edible figs which were used for caprification, and that this operation appeared to him nothing else than a tribute man pays to ignorance and prejudice.

The general skepticism regarding the practice is evidenced by the fact that in 1898 W. T. Swingle was ridiculed by scientists in Italy for his belief in the necessity for caprification. Furthermore, Dr. Gustav Eisen, in a personal letter dated October 3, 1939, when he was 92 years of age, wrote: "When I first 
announced my final conclusions about caprification and of the necessity of importing the Blastophaga at a horticultural meeting held in Fresno, 1887, I was hooted down and some of the mob whistled." The true nature of caprification was clarified by the successful introduction of the blastophaga into California in 1899 and by subsequent studies of the habits and life history of this insect.

\section{Page 43}

\section{Chapter V 43 Caprification}

The Blastophaga:The generic name, Blastophaga, is derived from two Greek words, blastos, germ, and phagein, to eat. The specific name, psenes, was used by ancient Greeks for the fig wasp, or Cynips. The name psenes has priority over the later name, grossorum, attached to the insect by J. L. Gravenhorst (1829). Swingle (1899) points out that "the earliest available descriptions of indubitable application to the fig insect and its common messmate are, respectively, I chneumon psenes and I. ficarius of Cavolini, published in 1782, the latter of which should be known as Philotrypesis ficaria"

Fig. 13. Blastophaga psenes; left, adult female, right, adult male.

Various technical accounts of Blastophaga psenes have been given, the most complete being that of Guido Grandi (1920). Practical aspects of its life history and the process of caprification may be found in publications by Eisen (1901), L. Trabut (1901), F. Vallese (1904), Condit (1918a and 1920/), and L. Buscalioni and G. Grandi (1938).

Blastophaga psenes belongs to the order Hymenoptera and to the family Agaonidae. The female (fig. 13) varies in size according to the caprifig from which she emerges but averages $2.5 \mathrm{~mm}$ long. The body is glossy and black; the wings have very few veins. The males are wingless, of an amber color, and have the abdomen so attenuated that it is much longer than the

\section{Page 44}

\section{Gondii 44 The Fig}

head and thorax combined. The female lays from 300 to 400 eggs, each being deposited separately in a short-styled flower.

According to Grandi there are from 10 to 15 male blastophagas for every 100 females. As pointed out by S. E. Flanders (1945), reproduction in the Hymenoptera is characterized by the production of males from unfertilized 
eggs and of females from fertilized eggs, a phenomenon known for a hundred years in the case of the honey bee. Variations in proportion of male and female blastophagas can thus be accounted for. Counts made in California of blastophagas issuing from more than 76 profichi of nine varieties showed an average of 495 females and 32 males from each fig.

The Profichi:Profichi push out on wood of the previous seasonl's growth, sometimes on still older wood, about the same time the leaves are appearing on the new twigs, usually the latter part of March or the first of April. This date is about the same for the coast as for the valley districts. The dates of maturity differ considerably, however, due to the climatic differences existing in the various districts. At Fresno full maturity is reached about the second week in June, approximately seventy days after the figs have been entered by the fig insect. Each profichi normally contains a large number of shortstyled pistillate flowers within the receptacle and a mass of male or staminate flowers near the eye. Actual counts of the numbers of flowers in different varieties show as many as 1350 pistillate and 220 staminate flowers in some and as few as 169 pistillate and 39 staminate in others. The normal proportion of flowers is 7 or 8 pistillate to 1 staminate.

Profichi on a tree in May or J une may be either of two kinds depending upon the presence or absence of the larvae in the pistillate flowers. Profichi designated by Eisen as "insectiferous" because they contain blastophagas in various stages of development may more correctly be called "inhabited" figs. Those not containing any blastophagas could then be called "uninhabited" or "blanks" rather than "polleniferous," since both inhabited and uninhabited profichi produce pollen. During the period of development, inhabited figs of standard varieties can generally be distinguished from uninhabited figs by their appearance. The former are dark green in color, firm, and plump; the latter are yellowish green, more or less ribbed, and inclined to be spongy.

The pollen, which is usually borne in profusion, matures just previous to the time the fig insects are ready to leave the fruit. The relative abundance or scarcity of the pollen produced by a caprifig can easily be gauged by breaking the fig open and shaking it over the open palm.

The Mammoni: Figs of the mammoni crop appear singly or doubly in the axils of leaves on wood of the current season/'s growth. Their abundance and the dates of their appearance vary considerably in the different varieties.

Mammoni figs of some varieties do not appear on the trees until practically all the blastophagas have issued from the profichi. This break between the profichi and mammoni crops is often so pronounced that some observers once believed the blastophagas had a breeding place 
45

\section{Caprification}

in some neighboring wild plant. Appearance of mammoni figs can be stimulated by breaking out the terminal buds of the growing twigs about the middle of May. Some of the axillary buds which push out will be mammoni. Fertile seeds are commonly found in mammoni figs, as many as 75 seeds in one fig. These result from pollination by blastophagas from the profichi crop.

Fig. 14. This chart portrays the duration of crops of the caprifig tree and the emergence periods of the blastophaga. (Adapted from fig. 26, United States Dept. Agr. Circ. 157.)

The Mamme:The term "mamme" is used to designate the crop of caprifigs that remains on the tree during the winter season. The crop is rather commonly known in California as "carry over." The presence of immature blastophagas in the mamme fig is usually essential to its proper development on the tree.

Mamme figs remain on the tree during the winter and are therefore subject to injury or total destruction by frost. No definite temperature limit may be set as indicating freedom from frost damage, since conditions other than temperature, such as humidity, variety resistance, and stages of development of the blastophaga enter into the question.

\section{Page 46}

Gondit

46

The Fig

Life History:The life history of Blastophaga psenes is simple (fig. 14). The insects pass the winter in the larval stage, go into the pupal stage in early spring, and about the first of April emerge as adults. The male, being the first to issue from the pistillate flower, immediately begins crawling over the surface of the flowers, gnaws an opening through a thin translucent membrane found just beneath the style, and impregnates the female while she is still inside the ovary. The female pushes her way out of the opening in the ovary made by the male and issues through the eye of the fig. The winged female then crawls over the surface of the leaves and fruit or makes short flights among the branches. On windy days she may be carried a considerable distance. The females that enter the profichi deposit an egg in 
each of numerous pistillate flowers and die after oviposi-tion is completed. The inhabited profichi then develop gradually until about the first week in J une or later, depending upon the temperature. From profichi the females pass into mammoni, and from these into mamme figs. Issuance of the females from profichi is most active during morning hours.

The habits and actions of the female blastophaga are exceedingly interesting. After the insect crawls through the mass of staminate flowers and issues from the eye of the caprifig, it attempts to clean off excess pollen" by stroking the body and wings with the front and the hind pairs of legs.j The wings, at first horizontal, soon take their normal, vertical position. In the struggle to enter small figs by wedging her body between the scales of the eye, the insect usually loses her wings. These, protruding from between the scales, are mute evidence that the female has gained entrance. It is not at all uncommon to find caprifigs with several females either crawling around the eye or trying to force an entrance. If such figs are opened, the spaces between the scales are often found to be black with living and dead bodies of the insects.

Inside the hollow syconium, the female crawls around over the surface of the flowers, evidently feeling her way with her ovipositor. When it is in a favorable position, that is, when the tip enters an open stigma, she stops, forces the ovipositor into the stylar canal, and then becomes passive during the act of oviposition, which lasts about 55 seconds. The actions of the females inside edible figs are very similar to their actions inside the caprifigs; however, as the long-styled flowers are not adapted to oviposition, the insects finally perish after their futile attempts to perpetuate the species but not before pollination has been accomplished.

The Practice of Gaprification:Smyrna-type figs, which require caprification, are grown in the Smyrna district, in Greece, Algeria, Portugal, in parts of Spain, and in California. In Algeria the best caprifigs grow in certain favorable districts. Convoys of 30 to 60 mules at a time formerly went from Bougie, Setif, or Tizi-Ouzou to collect profichi from selected trees. In the Meander Valley, caprifig trees grow in protected places, from which the figs are gathered and sold on the markets early in the morning. In seasons of scarcity, ship loads of profichi are secured from the nearby Greek islands. Caprifig trees in California have been planted mostly in

\section{Page 47}

\section{Chapter V 47 Caprification}

rows or in groups among the Lob Injir (Calimyrna) trees. However, there is an increasing tendency to get the former entirely away from the vicinity of the orchard, for separate plantings of caprifig trees, long advocated in California, could be supervised so that endosepsis might be more readily 
controlled or entirely eliminated.

The grafting of a caprifig branch in each Lob Injir tree has been tried and found to be unsatisfactory for two reasons: such a branch takes up space which should be producing edible figs, and regulation of the rate of caprification is practically impossible.

Fig. 15. This chart illustrates the total number of caprifigs and baskets to be used for medium caprification of Lob Injir trees having branch spread of 6 to 20 feet, on the basis of four distributions of caprifigs for the season. Thus, a 14-foot tree would require 2 caprifigs to each basket at each of the four applications.

Lob I njir figs that are either light green and glossy or dark green and dull and approximately one inch in diameter are in ideal condition for caprification, although blastophagas will enter figs somewhat smaller or slightly larger. Figs from 1.5 to 2.0 inches in diameter begin to dry out and eventually drop off unless caprification has taken place. A single blastophaga well dusted with pollen apparently can bring about good pollination of flowers and proper maturity of the fig. A count of the fertile seeds in each of 21 Lob Injir figs into which one insect had entered, showed an average of 850 seeds per fig.

The general practice in caprification is to distribute the figs at intervals of four days over a period of about three weeks. Figure 15 shows trees with spread of branches from 6 to 20 feet, the number of containers or baskets for each tree, and the number of caprifigs to be distributed. For example, a 16-foot tree would have two baskets with two figs placed in each basket every four days, a total of 16 figs for the season. The results

\section{Page 48}

Gondii

48

The Fig

of recent experiments on caprification indicate that medium caprification as suggested in figure 15 results in a medium crop of good figs, while heavy caprification, such as 32 caprifigs for a 14-foot tree, results in a heavier crop but also in a considerable increase in the amount of cull fruit due to various spoilage diseases and insect infestation. Medium caprification is practiced in the fig districts of Smyrna. According to Hagan, 5 caprifigs are strung on a reed and 4 or 5 such strings are tossed into each tree. As few as 15 caprifigs are used in small trees and as many as 45 are placed in large trees, usually in two applications. 
Picking Caprifigs: Caprifigs are ready to pick as soon as or shortly before the male insects begin to issue and the stamens are beginning to shed pollen. Profichi picked somewhat green may mature and allow insects to issue but the pollen may not mature properly. The female blastophaga is absolutely of no value in caprification unless dusted with viable pollen. Picking practices vary. Some pickers use a picking bag into which they drop the figs, while others detach the mature figs from the branches, allow them to fall to the ground or onto a canvas, and then put them in boxes.

The holding of caprifigs in cold storage is a common practice. Mamme figs can be held at 360 to $400 \mathrm{~F}$. for a considerable period if they are kept from excessive drying out. Profichi can be held in good condition at 400 for at least ten days.

Containers: Some growers in California distribute profichi by the method used in Smyrna. The figs, strung on raffia or on fine wires, are suspended among the lower branches or hung higher up in the tree by means of a pole. Various containers have gradually come into use. Perforated paper bags are commonly attached to lower branches by means of thumb tacks. Unless the weather is warm and dry, however, figs inside paper containers often develop molds which are carried into Smyrna figs by the blastophagas. More permanent containers are wooden fruit baskets, or baskets made of galvanized wire or of \%-inch mesh wire netting.

Artificial Pollination:Hand pollination of figs in California was first accomplished by George Roeding, who in 1890 transferred pollen from a caprifig to Smyrna figs by means of a toothpick. The following year by using a glass tube drawn out to a fine point, he succeeded in getting 150 figs to set and mature excellent fruit. A color illustration of one of these Smyrna figs "brought to full maturity by hand or blowpipe pollination in 1897" is shown in the United States Department of Agriculture Yearbook for that year. Dr. Eisen successfully pollinated White San Pedro and Gentile figs in Kern County with pollen transported in a glass-stoppered bottle from a tree 200 miles distant and introduced into the figs with a goose quill. According to C. G. Savage (1925), figs were pollinated in Australia by cutting a small piece from the apex of the fruit and inserting in its place a similar piece of a caprifig containing pollen-bearing flowers.

\section{Page 49}

\section{Chapter V}


Effects of Gaprification:Lob Injir figs which have been caprified undergo striking changes within a few days. The glossy surface becomes dull and gradually takes on a grayish bloom; the ribs disappear, leaving a smooth surface. Size does not increase much at first, but as the achenes inside develop, the figs gradually swell from the 1-inch diameter when caprified to 2) 4 inches or more when mature.

Caprification also markedly affects most common figs. \{See Condit, 1941c.) In general, caprified figs are larger than uncaprified figs of the same variety. For example, at Riverside, 50 caprified Dottato (Kadota) figs averaged 44.4 $\mathrm{mm}$ in diameter and 45.4 grams in weight, while 50

Fig. 16 \{left). Female Philotrypesis on the surface of a fig. The one on the right is in the act of oviposition.

Fig. 17 (right). Female Philotrypesis in the process of forcing her ovipositor into a fig receptacle. Both figures adapted from J. L. Lichtenstein (1919).

uncaprified figs from the same or neighboring trees averaged $38.1 \mathrm{~mm}$ in diameter and 32.3 grams in weight. The skin of normally yellow or greenish figs, such as Dottato and Adriatic, remains a grass-green color in caprified specimens, even at full maturity. Verdal Longue figs that are caprified show a much deeper violet color of skin than do uncaprified specimens. [

Although caprification affects color of pulp of most figs, some common figs, such as Marseilles and Beall, show a white pulp whether caprified or not. Most common figs, such as Dottato, which normally have an amber or uncolored pulp, have strawberry-colored pulp when caprified. The pulp of Adriatic, Barnissotte, and Verdal Longue becomes blood-red in color when the fruit is caprified. The flavor of a caprified common fig, such as Adriatic, is generally more acid than that of an uncaprified specimen of the same stage of ripeness. The excellent flavor of Lob Injir figs is due in a considerable degree to the nutty kernel of the fertile seeds; fertile seeds in common figs also have a nutty flavor which is imparted in

\section{Page 50}

Condit

50

The Fig

some degree to the pulp. Caprification of common figs, however, often results in an increased amount of fruit spoilage. 
Charles Taylor, a fig packer at Fresno, believes that Adriatic, Mission, and Dottato figs should never be caprified because the quality is definitely impaired, even though size of the fruit is improved.

A Messmate and other Enemies of Blastophaga:It has long been known in Mediterranean fig districts that caprifigs harbor not only blastophagas but also another species of insect, known to the Greeks as Ichneumon but now designated either as Philotrypesis fie aria or as P. caricae (fig. 16, 17). Grandi (1923 and 1930a) studied this species and concluded that the female Philotrypesis may live 15 to 25 days in captivity, as compared to only 3 or 4 days for the female blastophaga, that caprifigs entered by Philotrypesis alone drop off when small, and that no caprifigs harbor Philotrypesis only.

Philotrypesis is undoubtedly a messmate since it is unlikely that a larger insect than the blastophaga would be parasitic, although it might be predaceous. Hagan (1929a) gives a good account of Philotrypesis caricae and his reasons for believing it not to be a parasite. Swingle (1908) reported that "Philotrypesis ficaria, which in the Old World often takes up one third or even one half the space in the caprifigs, failed to get established in this country" even though it was seen issuing at Fresno in 1898.

According to Gasparrini (1863), a nematode infesting the blastophaga was collected by Dr. Trabut in Algeria. Apparently it utilizes the insect only as a carrier. Howard (1901) reported that at Fresno no trace was found of the nematode, which is said in I taly to be a constant inhabitant of caprifigs and edible figs. He also stated that the blastophaga "has other unimportant natural enemies like the Chrysopa and ladybird larvae, but its greatest natural enemies are found in spiders .... One little wolf spider was observed to catch Blastophagas as they emerged from the figs.,, Ever since 1900, spiders and their webs have continued to reduce the population of the blastophaga in California, but the loss is seldom serious. Dragon flies often hover over caprifig and Lob Injir trees and seize female blastophagas out of the air.

Standardization of Caprifigs: A standardization law for the handling of California caprifigs was proposed at the Tenth Annual Fig Institute held in Fresno, November 12, 1926. This was later adopted as Senate Bill No. 148. The Agricultural Code of California for 1943, Sections 991 to 998, defines such terms as profichi, mamme, and blanks, gives standards for the profichi crop, declares surplus caprifig trees a public nuisance, and specifies the treatment of caprifigs for endosepsis. 
Natural Seedlings: In fig districts of the Old World, fig seeds have, from time immemorial, been disseminated by birds and animals, and natural seedlings have appeared on walls, buildings, hillsides, and in neglected places. Leclerc du Sablon (1908) says that in the vicinity of Fontaine de Vaucluse there were almost a hundred fig trees, undoubtedly from seed, about one third male and the rest female with fertile seeds. In Italy, Longo (1911) saw a veritable Eden of fig seedlings of all ages and sizes near Monteriggioni. Since figs with fertile seeds are not so common in the New World as in the Old, fig seedlings are less generally found there. In Georgia and other southern states, however, there are numerous seedlings grown by chance from fertile seeds of imported figs. Natural fig seedlings are seen only occasionally in California. The Beall, a California seedling of unknown parentage but of good quality, emphasizes the possibilities of getting improved varieties even from chance seedlings.

Seedlings of Miscellaneous Parentage:The number of cases in which fig seeds have been planted in the hope of getting a good variety, is surprisingly large. In 1875 the Reverend Robert J ope of Indianola, Texas, obtained several hundred plants from seeds washed from dried Smyrna figs. As early as 1885 Eisen had raised several thousand seedling figs from seeds of the choicest Eleme and Erbeyli figs of Smyrna. In 1901 he reported that these seedlings produced some trees with purely female flowers and others with male flowers, in varying proportions. W. F. Massey (1894) found that fig seeds germinated almost as readily as cabbage seeds. In 1903 he stated that he had grown hundreds of seedlings from imported figs but that their fruit failed to set in the absence of blastophaga.

Both A. Pellicano (1907) and G. Guglielmi (1908) regarded the Dottato as a decadent variety in Italy and suggested the desirability of developing better varieties by selection from seedlings. A. Siniscalchi (1911) advocated the same thing and said this had been carried on since 1885 by Prince Belmonte, who grew seedlings of the Columbrane and Smyrna figs.

In his booklet Fig Culture, A. C. van Velzer (1909) states that fig seeds generally produce seedlings which are worthless. It is not apparent whether Luther Burbank (1915) actually made fig crosses. He did grow seedlings in abundance, 99 out of 100 producing worthless fruit, and seedlings of white figs producing quite as likely black or brown figs as white ones. His attempt to hybridize the fig and the mulberry was unsuccessful.

Previous Work in Fig Breeding:General accounts of previous attempts directed towards fig improvement by breeding are given by 
52

The Fig

I. J. Condit (1928b) and by H. P. Traub and T. R. Robinson (1937). Probably the most carefully planned work of this sort in the Mediterranean districts was that of Trabut (1922). He succeeded in crossing not only different varieties of figs and caprifigs, but also two closely related species, Ficus palmata and F. pseudo-carica, with pollen of F. carica. At the Mont-pellier garden he grew numerous seedlings from these crosses, but no subsequent report on their behavior or value has been noted.

One of the most enthusiastic breeders of figs in the southern United States was B. W. Hunt $(1911,1912)$ of Eatonton, Georgia. For female parents he used Brown Turkey, Green Ischia, and Celeste, and for pollen he first resorted to local seedling caprifigs. Later he obtained blastophagas which effected pollination of the edible figs available. One of his main objectives was to produce a fig with a peduncle long enough to hang downwards and thus to shed rain away from the eye. His seedling fig, the Hunt, a cross of Green Ischia with pollen from California, has the desired character, is larger than Celeste, but is too tender to ship well as a fresh fruit. The names of $\mathrm{E}$. B. Pauly, San Antonio, Texas, and of Francis Heiny, Brawley, California, deserve mention here as other enthusiastic growers of fig seedlings. The latter has a number of seedling figs and caprifigs having Ficus pseudo-carica as the male parent. Dr. T. Tanikawa, Okitsu, Japan, has long been hybridizing figs and has secured several promising seedlings. I. N. Rjabov (1939) tells of the results of 125 yearsl ' work at the Nikita Experiment Station in hybridizing various fruits, including the fig of which five new varieties of improved yielding capacity and quality were secured.

Fig breeding at the Angleton Experiment Station in Texas was initiated in 1934 when pollen was received from California and fruits of several varieties were pollinated. R. H. Stansel and S. H. Yarnell (1936) reported that crosses were made with pollen from a Hamma caprifig using Magnolia, Allison, Celestial, and Green Ischia as seed parents. According to H. M. Reed and S. H. Yarnell (1939, 1940), twenty-four of these seedlings produced edible fruit, mostly from the Magnolia X Hamma cross, but none was particularly outstanding. Of the twelve seedlings which bore fruit in 1940, one was thought to have some possibility as a shipping fig.

The United States Department of Agriculture in 1909 published a leaflet entitled, "Cooperative Distribution of New Varieties of Smyrna Figs and Caprifigs $/ \backslash$ ' in which it was announced that there were ready for free distribution several thousand seedlings grown from some of the best drying figs, such as Lob Injir and Rixford. Many growers, taking advantage of the offer, planted cuttings of the named varieties as well as the seedlings. Seventeen years later Rixford (1926) reported that free distribution of trees had been discontinued and that seedlings were then being grown at Chico, 
California. The Kearney caprifig is a Department seedling, described by Condit (19286), the original tree being designated as Rixford No. 2830.

Work on seedling figs done at the Yuma Experiment Farm of the United States Department of Agriculture is recounted by W. A. Peterson (1913), by R. E. Blair (1914, 1915, 1918, 1920), and by E. G. Noble

\section{Page 53}

\section{Chapter VI}

S3

Fig Breeding

(1922). More than a thousand seedlings were planted in orchard form, but the project was abandoned in 1922, largely because of a serious infestation of garden nematode.

Inbreeding of figs was suggested by Eisen in 1901. He regarded it as highly desirable "that we should raise new varieties of caprifigs from seeds of caprifigs." Longo $(1918,1924)$ tried this experiment in Italy and found the results were not essentially different from those secured by growing seedlings of edible figs. Rixford (1918) counted as many as 75 fertile seeds in one mammoni fig and at Chico grew a large number of seedlings from such seeds. Fertile seeds were obtained by Condit from Kearney mammoni figs selfed with pollen from the profichi crop on the same tree. Of 89 seedlings grown from such seeds, 62 bore caprifigs and 27 bore edible figs; all were discarded as worthless. Other progenies of selfed caprifigs are now being grown, and these may help to show whether maleness is dominant in caprifigs.

The Maslin Seedling Fig Orchard:The Maslin seedling fig orchard at Loomis has had a distinct bearing upon the development of the California fig industry, as related by E. W. Maslin (1890), Swingle (1908, 1909a), and Rixford (1918). Mr. Maslin hoped, by growing seedlings of Smyrna figs, to be able to settle or, at least, to throw some light upon the controversy over the failure of the imported Smyrna fig trees to set and mature fruit. Accordingly, he obtained such seeds in 1885 and grew the seedlings in a hotbed until 1888, when they were transplanted to orchard rows, 153 trees in all. As all the fruit dropped, Mr. Maslin abandoned the orchard and it was neglected until 1901, when blastophagas were introduced by George Roeding. In 1908 the United States Department of Agriculture leased the orchard in order to ensure growers a source of supply of caprifigs and to provide material for fig breeding. Of the 139 trees found in bearing, 74 were of the caprifig type and 65 of the Smyrna type. 
Swingle $(1908,1912)$ reported that a number of the edible figs were very promising and that at least two bore fruits which became sealed with a drop of gum as they ripened. Four varieties, Eisen, Hilgard, Rixford, and West, which originated as Smyrna-type seedlings in the Maslin orchard, were described by Rixford in 1918. None of them was ever planted commercially and few are now available even for trial in small plantings. Some of the Maslin seedling caprifigs are still to be found in private collections.

Fig Breeding in California:The importance of fig breeding was recognized a few years ago when the California Agricultural Experiment Station started a comprehensive study of fig diseases under the direction of R. E. Smith. His statement of the objectives, as given in the 1922-23 Report of the Station, emphasized the possibility of obtaining disease-resistant varieties and the particular desirability of developing a light colored fig as good as or better than the Black Mission. Several thousand seedlings were obtained from crosses made by Smith and his associates

\section{Page 54}

\section{Condit}

\section{4}

The Fig

and were planted, mostly at Davis. Cuttings from these seedlings were taken in 1928 for fruiting at Riverside. Since 1928 the work in fig breeding has been carried on at the University of California Citrus Experiment Station, Riverside. A summary of the results so far obtained is here given.

Up to and including the 1944 season, 141 combinations have been made, involving 49 female parents and 66 male parents. Twenty-four crosses were made of the Dottato (Kadota) fig, 14 of the Lob Injir (Calimyrna), 13 of the San Piero (Brown Turkey), and 12 of the Mission. The total seedling population numbers 12,517 . Of those bearing fruit, 4944 are of the caprifig type and 4843 are edible figs, approximately half and half. Seedlings discarded as worthless number 8053 . Some 35 edible figs and 12 caprifigs are designated as having sufficiently good qualities to warrant tests in commercial fig districts.

One of the main facts disclosed during the progress of the California experiments is that selection of parents is of prime importance. Lob Injir, for example, has proved to be a poor female parent on account of its large eye, which is transmitted to offspring. San Piero is also undesirable because it transmits its large open eye and hollow interior. 
Every fig cross involves the use of pollen from a caprifig, and it has become very apparent that some caprifigs are more valuable than others for use as male parents. For example, when caprifigs of the two species Ficus palmata and F. pseudo-carica are used, the non-parthenocarpic, or Smyrna-type, character behaves as a dominant. Seedlings from crosses having either one of these as the pollen parent, therefore, bear edible fruit requiring caprification. The use of pollen from parthenocarpic caprifigs results in a large percentage of parthenocarpy in both caprifigs and edible figs of the progeny. For example, 12 parthenocarpic figs, each crossed with a parthenocarpic caprifig, produced a total population of 1109 seedlings, of which 316 caprifigs and 337 edible figs developed parthenocarpic fruit. Seedlings of certain crosses, especially those involving Ficus palmata or $\mathrm{F}$. pseudo-carica, are exceptionally precocious. Many bear fruit the same season that buds are placed on mother trees, less than twelve months from the time the seed is planted.

Also, in breeding for caprifig improvement, careful selection of parents is very important. Since parthenocarpy is undesirable in a caprifig, only nonparthenocarpic parents should be used. It is now apparent that caprifigs with a hollow center, especially in the mamme crop, may be desirable on account of better penetration of the disinfectant used in treatment for endosepsis. Figs with hollow centers are therefore being used both for male and female parents in the attempt to get such caprifig varieties.

Selection of parents is again seen to be an important consideration if one expects to increase size of fruit by a breeding program. When two large figs are crossed, half of the progeny bearing edible figs are large and half are medium in size. When a medium fig is crossed with a large caprifig, the largest percentage of the progeny is of medium size. If two medium figs are crossed, the progeny produces very few, if any, large figs. If a medium fig is crossed with a small caprifig, small sizes greatly predominate in the seedling progeny.

\section{Page 55}

Chapter VI

55

Fig Breeding

Black color of skin is dominant over green, as exemplified in a cross of green Adriatic with a caprifig bearing green profichi but purplish mamme figs. In the progeny, half of the figs, both edible figs and caprifigs, were purplish and half were green. In the cross of the Adriatic with green Roeding No. 1, none of the edible progeny was purplish, but one third of the seedling caprifigs showed a purple skin. Internal purple color is generally dominant over white 
in seedling caprifigs.

Early appearance of leaves can be readily transmitted, especially by such caprifigs as Ficus palmata. Late maturity of edible figs, as shown in Verdal Longue, is a dominant character. Certain leaf and twig characters are dominant over others in some crosses, as, for example, non-lobed leaf over lobed leaf and reddish-brown color of twigs and petioles over green color in Ficus palmata caprifigs.

The Smyrna-type character is almost, if not entirely, dominant in crosses of this type, regardless of the male parent used. Hunt (1912) reported that no plant breeder had produced from Smyrna seed a fig tree which would perfect its fruit without caprification. This contradicted the statement of Massey (1894) that one tree out of a lot of 100 Smyrna seedlings bore several figs the second year. Rixford (1919) stated that a seedling fig tree, West X a Maslin caprifig, both presumably non-partheno-carpic, matured fruit at Indio, California, without caprification. The University of California tested 500 seedling edible figs from crosses involving three Smyrna-type figs as the female parents and found that not a single seedling showed development of fruit by parthenocarpy.

Methods Used in Fig Breeding: Few if any common fruits are so easily hybridized or so productive of fertile seeds as the fig. No emasculation of flowers is necessary, and pollination by blastophaga or by hand usually produces several hundred seeds per fruit. Various methods of pollination are used. Both Hunt in Georgia and Tanikawa in J apan split open the apex of the fig and introduced pollen on the point of a knife blade. A single caprifig containing live blastophagas and pollen can be enclosed in a paper bag and tied over a branch bearing female figs, but this will probably result in excessive seed development, with the resultant splitting or rotting of the maturing fruit. Stansel (1936) used a hypodermic needle, with a bulb attached, to introduce the pollen. This was later improved by soldering to the needle a fine glass tube through which excess air could escape, and by the addition of a stoppered glass cup to hold the pollen. Pressure on the rubber bulb caused pollen to be picked up from the cup and forced into the fig through the hollow needle.

In California, mature profichi of the selected male parent are either split lengthwise or a circular disk with the stamens attached is removed from the apex. From such pieces, left to dry overnight, the pollen can readily be collected. Pollination is accomplished by means of a glass tube drawn to a point, with a rubber nipple attached to the opposite end. A glass rod or small nail is used to open the eye, and the side of the fig is pierced to let the air escape as the pollen is puffed in. Figs pollinated in J une mature in August, at which time the fertile seeds can be secured. 
Condit

56

The Fig

Seeds planted in flats in mid-October are ready for transplanting to a greenhouse bed early in December, the seedlings being placed about 3.5 inches apart. By the first of April the seedlings reach a height of 6 to 8 inches and are then ready for budding into sucker wood of orchard trees prepared a year in advance by heavy pruning. Each seedling is treated as a bud stick. Two shield buds are cut and each inserted into a T-shaped incision in the bark, cotton string being used for wrapping. A growth of three or four feet the first season is not unusual from April budding.

Fig. 18. Fig chimeras. Upper, Adriatic normally green, shows two sectors of skin colored violet-purple. Lower, Panache, is normally banded with green and yellow stripes running from base to apex.

The growing of seedlings on orchard trees was advocated by J ohn Wright in 1891, when he wrote: "To ensure early fruiting of seedlings, they may be grafted or inarched on old trees when they may fruit in the third year; on their own roots they may not fruit till the sixth or seventh year, if then." This is corroborated by California experience. The progeny of one cross with a population of 311 was divided into two lots. Thirty-nine seedlings of the first lot, budded into orchard trees in 1937, set and matured fruit during the seasons of 1938 to 1941 . The rest of the seedlings, 272 in number, were planted close together in nursery rows; some fruited in 1939 and 1940, but in 1944 there were still 40 per cent which had not yet fruited.

Inter-Specific Grosses:There are apparently no published records of crosses between two distinct species of the genus Ficus if we leave out

\section{Page 57}

Chapter VI

57

Fig Breeding

of consideration F. palmata, F. pseudo-carica, and allied forms which are closely related to F. carica and whose caprifigs are inhabited by the same Blastophaga. One objective in making a collection of species of Ficus is to attempt inter-specific crosses. One such effort has been successful in 
California. Hybrids have been secured by pollinating non-parthenocarpic fruits of Ficus pumila with F. carica. This represents a cross between an evergreen vine fig and a deciduous tree fig. Some of the two-year-old seedlings are deciduous, some evergreen; the habit of growth tends to be vine-like; the leaves are thin and lobed, more like those of F. carica. None has yet fruited.

Chimeras:Chimeras, presumably originating from somatic mutations, are not common in fig varieties. The few reported involve variegations in leaf or fruit. At least two accounts of fig chimeras have been published, the first by $\mathrm{J}$. $\mathrm{L}$. Collins (1919) and the second by Condit (1928a). Collins illustrated and described a sectorial chimera of a Lob Injir fig which differed from other chimeras "in that the cell in which the change took place was not in the developing of young fruit itself, but in a cell of the young shoot on which the fruit grew. A few of the leaves growing on the tree which produced the figchimera were characterized by white areas or sections."

Condit reported a still more striking chimera in an Adriatic fig (fig. 18) which showed one third of the surface to be green and two thirds purple, with this dark sector divided by a narrow ribbon of green. The bands of light and dark color persisted when the fruit became dry. Another Adriatic tree had one twig which produced dark colored figs instead of the normal green fruit. One large branch in a Lob Injir tree at Reedley, California, bore both albino and variegated leaves year after year, although the fruit showed only faint indications of variegations. None of these chimeras has been saved by propagation.

The most striking fig chimera yet reported is that exhibited by the French variety Panache and described by various horticultural writers. (See Condit, 1928a.) The immature fruits are beautifully striped with bands of green and yellow (fig. 18) which gradually become a sulphur to golden yellow as the figs mature. The branches of the Panache tree also show variegation during the first yearl's growth, but the leaves are of a normal green. Seeds of Panache from open-pollinated flowers did not produce any progeny with variegated fruits or twigs.

\section{Page 58}

Chapter VII

\section{FRUIT CHARACTERS}

During the many centuries in which the fig has been cultivated for its edible fruit, numerous varieties have been selected, propagated, and named. For example, the father of Ulysses, the hero of the Odyssey, gave his son 20 fig trees all with names. As early as the 4th century B. C, Theophras-tus stated that most of the cultivated fruits, including the fig, had received names. In the first century of the present era Pliny listed 29 varieties of the fig. 
Variety names of figs, however, such as those recognized in modern pomological nomenclature, do not appear in literature until the 17th or 18th century. Descriptions of varieties by such pomologists as J ean de La Quintinie (1693) and Henri Duhamel du Monceau (1755) in France, Philip Miller (1768) and George Brookshaw (1812) in England, and Gallesio (1820) in Italy are in many cases sufficiently accurate and detailed to enable the identification of these varieties, some of which are now being grown commercially. It is regrettable that sometimes the description is brief or even lacking entirely, as in the case of Miller, who stated that the "common blue or purple fig is so well known as to need no description." Descriptive lists of fig varieties have been published by Robert Hogg (1866) and Wright (1894) in England, Estelrich (1910) in Spain, Vallese (1909) in Italy, Bobone (1932) in Portugal, Trabut (1904, 1923) and Mauri (1942) in Algeria, Eisen (1901) and Starnes and Monroe (1907) in the United States. Reference is found occasionally to a work prepared at Nice by Geny in 1867 on the figs cultivated in AlpesMaritimes. Unfortunately, this album of color plates was never published, although it was considered of great value by Eisen.

Collections of Fig Varieties:Variety collections of figs have been established and maintained in many places. Notable among such collections, especially for California growers, is the Chiswick collection, maintained until recently in the glass houses of the Royal Horticultural Society of London, England. In 1894, scions of each variety, about 66 in all, were secured by the United States Department of Agriculture under Plant Introduction (P. I.) numbers and forwarded to California, where they were successfully grafted into old trees in the orchard of the California Nursery Company at Niles. Subsequently the collection was transferred to the United States Plant Introduction Garden at Chico. According to J. C. Shinn (1892), the University of California had, at its various stations, about 60 varieties of figs available for distribution. A variety orchard including all the available kinds from the Chiswick collection as well as numerous other kinds, was established in 1928 at the University of California Citrus

\section{Page 59}

\section{Chapter VII}

59

Fruit Characters

Experiment Station, Riverside. This collection now includes 145 distinct varieties of caprifigs and edible figs as well as several thousand seedlings.

Unfortunately, the early work of Starnes in Georgia, of Eisen and Shinn in 
California, and of various others was discontinued before adequate illustrations and descriptions of the less common varieties were made. Starnes and Monroe in 1907 stated that "no fruit, comprising as in this case but a single species, is so badly mixed as is the fig in its nomenclature." It is hoped that the continued maintenance of a fig-variety collection at Riverside, California, and the accumulation of notes on variety behavior will serve to clear up some of the present confusion in nomenclature.

Classification of Varieties:The classification of figs into types, Common, Smyrna, and Caprifig, is based mainly on botanical characters and is, therefore, fairly definite. Pomological classification of fig varieties, however, is not so simple. This is also true of other fruits, such as apples. And yet various authors have found that the grouping of fig varieties according to certain characters aids considerably in their identification.

Louis Noisette (1829) classified figs into two groups based on external color. Each of these two groups he subdivided into fruits spherical or oblate and fruits oblong. Hogg (1866) based his classification upon shape, color of skin, and color of flesh. Bobone (1932) is apparently the only author who differentiates between brebas and second-crop figs in a pomological key. He further subdivides figs on the basis of external color, shape of the base, shape of the body, and color of the pulp.

Color:There are three general color classes into which fresh figs may be segregated: (1) fruit green or yellow; (2) fruit more or less shaded with bronze, copper, or violet; and (3) fruit decidedly dark violet or purplish black. The limits of these color classes are not always sharply defined, the external color depending upon the light intensity, temperature, humidity, and upon the presence or absence of fertile seeds. For example, the Dottato fig in a cool coastal climate is green in color, but in a hot inland climate it is lemon yellow. Adriatic is green or bluish green in color in the cool climate of San Francisco Bay, but in the hot inland valleys it is often golden yellow.

Examples of bronze- or copper-colored figs are Brunswick, Celeste, Gouraud Rouge, Pied de Boeuf. Figs shaded with violet are St. J ean and Partridge Eye. Seldom are these intermediate figs so attractive in color for the fresh-fruit market as the clear yellow or the purplish-black figs. Mission, San Piero, Ischia Black, and Pastiliere are deep purplish black in color. The black color persists in the dried fruit of the Mission and Ischia Black but changes to an undesirable brown color in San Piero. Color of fresh figs, like that of other fruits, is often obscured or modified by the bloom, which is a surface character. Furthermore, color is seldom uniform over the whole surface. Purplish-black Barnissotte commonly shows irregular patches of green persisting around the apex or on the sides of the body. Asaph Grasovsky and J. Waitz (1932) state that Shunnari "is very easily distinguished by a bright red circle around the eye," the skin 
Gondit

60

The Fig

being green with brownish ribs and the eye scales bright red. A few figs, notably Violette de Bordeaux and Ischia Black, show a distinct reddish-brown color before they are half grown. In some cases the skin color is modified by colored meat. Thus Clare and caprified Adriatic often have a violet shade due to the underlying violet meat. Miller (1768) says of Ischia that "the skin is thin, of a green color, but when it is fully ripe, it is stained through by the pulp to brownish cast."

Fig. 19. Forms of fig fruits: A, B, Marseilles and Martinique, spherical without and with neck; C, D, San Pedro and* Lob I njir, oblate without and with neck; E, F, Bourjassotte Grise and Brunswick, turbinate with and without neck; G, Fraga, pyriform with thick neck; $\mathrm{H}$, San Pietro, pyriform with neck undifferentiated from body; I, Marabout, neck long and curved; J, Datte, oblique-pyriform.

The common names White Ischia and White Genoa indicate white figs. All such figs are yellow or green rather than white. The only reference found to a really white fig is by George Henderson and Allan Hume (1873), who, in Yarkand, ran across an excellent variety with very large fruit, "often pure white as if it had been blanched."

Form: The form of the fig fruit, like the color, is affected by climatic conditions, by the presence or absence of fertile seeds, and by vigor of growth. Although there is considerable variation in fruit on the same tree and during the same season, forms of fresh figs are fairly characteristic of the variety. Form is commonly associated with the presence or absence of a neck.

Bobone (1932) designates fruit length as $C$, diameter as $D$. The shape of the fruit is then expressed by the ratio $D / C$. When $D / C$ is greater than 1.1 , the fruit is said to be oblate; when between 0.9 and 1.1, round; and when less than 0.9, oblong. Typical forms of fig fruits are illustrated in figure 19.

\section{Page 61}

Chapter VII

61 


\section{Fruit Characters}

Size: Figs are in general large, medium, or small. In their descriptions of fig varieties Starnes and Monroe (1907) give measurements of (1) perpendicular and (2) transverse axes of fruits. The limits of these measurements for figs of the various sizes are: small, $29-46 \times 28-38 \mathrm{~mm}$; medium, 38-54 X 35-49 mm; large, 52-70 X 41-56 mm; very large, 75 X $66 \mathrm{~mm}$. Grasovsky and Waitz (1932) describe Khdari as a large fig measuring about 65 X $60 \mathrm{~mm}$. Eisen refers to Lipari as "the smallest of all figs about three-fourths to 1 inch long." In cool coastal climates of California, such figs as Adriatic and Osborn reach an unusually large size, at least twice the size of figs of the same varieties grown in the hot valleys of the interior.

\section{Q 9999}

Fig. 20. Fruit stalks: A-E, variously enlarged; FI, long and slender; J, short and thick. A, Brunswick; B, Yellow Neches; C, Monaco Bianco; D, Precoce de Barcelona; E, Violette de Bordeaux; F, Pseudo-carica capri; G, Palmata capri; H, Celeste; I, Hunt; J,

Mission.

Neck:The neck of a fig is the constricted part located between the body and the stalk (fig. 19). There are figs, such as Marseilles, that have no neck. Others, such as San Pietro and Brunswick, have the basal half narrowing so gradually between the body and the stalk that they also can generally be described as having no neck.

In some figs, such as Lob Injir, the neck is thick and joins the body abruptly; in others, such as Col de Dame, it is thick but tapers more gradually from stalk to body. The neck may be long and slender, as in Marabout; if so, it is often curved or somewhat falcate.

In most figs the neck is round in cross sections; in a few it is angular or triangular. The neck of some figs is characteristically compressed or flattened laterally, as in Lob Injir and in many of its seedlings, such as Maslin caprifigs No. 147 and No. 148. Some common figs also have a flattened neck, examples being Bourjassotte and Martinique. This character, flattened neck, has recently been discussed by Condit (1943).

\section{Page 62}

Gondit 
The Fig

Stalk:The stalk joins the fig body or the neck to the twig. It may be short, medium, or long, thick or slender, straight or curved, and rounded or angular (fig. 20). The stalks of some figs, such as Violette de Bordeaux, Yellow Neches, and many specimens of Brunswick, are prominently swollen or enlarged, especially near the body.

The stalk is generally firmly attached to the twig; it loosens naturally after an absciss layer is formed and allows partially dried figs to drop. In a few figs, notably Pastiliere and Barnissotte, the stalk is rather loosely attached and many mature fruits drop before they start to dry. At the apex of the stalk are three more or less prominent bracts. These are generally closely appressed to the body but are sometimes loose and flaring.

Ribs: The ribs of the fig fruit are longitudinal ridges running from base to apex. The surface of some figs, like that of second-crop Dottato, is smooth and almost entirely devoid of ribs. At the other extreme are Pied de Boeuf and Castellana, the ribs of which are so prominent as to make the surface corrugated.

Ribs are mostly confined to the body of a fig. They may be continuous and unbranched or they may dissolve toward the apex into branches. Sometimes, especially in immature fruit, they show as mere lines colored more darkly than the body. Prominent ribs are objectionable in figs to be used for freshfruit shipping because they make the skin more subject to injury in handling.

Ostiole and Eye:Ostiole means literally "little door." It is the name applied to the apical opening characteristic of fig receptacles. Eisen refers to this structure as the "eye" and states that it is "the opening in the broad end or apex of the fig."

It seems best to differentiate between the ostiole, or complete orifice of the syconium, and the eye, the part which is apparent at the surface. The eye of an immature fig appears to be completely closed by the scales, or ostiolar bracts, but the female blastophaga is able to push her way between the scales, and thrips can enter freely. As figs mature, the eye may remain fairly well closed, sufficiently so in Mission and Dottato to prevent Carpo-philus beetles from entering.

R. H. Stansel and R. H. Wyche (1932) report that "the fruit of the Magnolia variety remains upright and has a more open end than that of the other varieties, which probably accounts for its tendency to sour readily, especially during damp weather." A. T. Potts (1917) also refers to the open eye of Magnolia which may be entered and injured by insects. Lob Injir and San Piero figs have large open eyes, allowing easy penetration of beetles and even larger insects, such as honeybees. Celeste is an example of a fig with a small, well-closed eye. Figs with medium eye but sufficiently open to allow 
beetles to enter are Brunswick and Adriatic. Actual diameter of the ostiolar opening of different fig varieties ranges from 2 to $12 \mathrm{~mm}$.

Some figs such as Dottato and Lob I njir exude at maturity a clear, sparkling, topaz-colored drop of gum into the ostiole and eye and are,

\section{Page 63}

\section{Chapter VII}

\section{3}

Fruit Characters

therefore, "self-sealed/`' Swingle (1909c) reported that Rixford figs "show a drop of pellucid gum completely filling the very narrow mouth of the fruit when it matures."

According to Mr. Fowler (1865), when Castle Kennedy is "within a few days of being ripe, a clear honey-looking substance of exquisite flavor commences to drop from the eye of each fruit. When quite ripe this substance becomes somewhat viscid, hanging like an elongated dewdrop, from half an inch to three-quarters in length, clear as crystal, giving a very remarkable appearance to the fruit." Thomas Moore (1872) reported that Negro Largo grown in pots in England had an open eye and generally a globule of syrup.

Clear drops of gum from Dottato figs are completely soluble in water and show the following analysis: reducing sugars, 45.53 per cent of the dry weight; total reducing sugars, after hydrochloric acid inversion at room temperature, 46.86 per cent, the sucrose being 1.33 per cent of the dry weight.

Eye Scales:Surface scales of the eye of the fig may be large, medium, or small, broad or narrow, acute or rounded, with or without scarious margin, same color as body of fruit or of a contrasting color, and flat or erect at maturity. In San Piero and some other figs the eye scales are pinkish, even in the small green fruit. In mature Fraga and Gota de Mel the rose-pink eye contrasts beautifully with the green or yellowish body. Almost without exception, eye scales of caprifigs assume an erect position at maturity, as they do in some edible figs.

Iris:The iris, according to Eisen, "is a colored zone surrounding the scales of the eye, situated between them and the elevated ridge." Starnes and Monroe (1907) seldom describe the iris. They do state that Brunswick has an "iris with rosy red scales," thus apparently confusing iris and eye scales.

According to Rixford (1918), Lob Injir has a large open eye "bordered by 
whitish protruding scales a little lighter than the skin, surrounded by a dark ring or iris." The character "iris" has not been used in blank forms for figvariety descriptions in California.

Skin:The skin of a fig, according to A. L. Winton and Kate Winton (1935), has no thick cuticle such as that found in the apple and the grape. The epidermal cells are colorless. The color of dark figs is found in parenchyma cells lying just beneath the epidermis. The skin may be dull, as in Ischia, or glossy, as in Dottato. In Madeleine the skin has a beautifully clear, waxy appearance.

In some varieties, such as Mission, the skin of mature fruit can be readily peeled back from the stem end; in others the skin adheres rather firmly to the meat. Some canners label their product "skinless figs"a misleading term. A more correct label would be "skinned figs" since the skin of the fresh figs is removed with lye. Texture of skin has an important bearing upon the commercial value of the fig. The firm or rubbery texture of the skin of the Dottato, for instance, makes this variety

\section{Page 64}

Condit

64

The Fig

almost ideal for canning purposes; and since the fruit is not easily bruised, it can be satisfactorily transported fresh to distant markets.

Checking of the skin is a characteristic of some fig varieties, notably of Verdal Longue and Panache. Commission men understand that this checking indicates maturity, and unless it is too pronounced, they do not consider it objectionable. Bourjassotte Grise in England has been described as follows: "When thoroughly ripe, the skin cracks slightly cross-ways and lengthways over the whole surface, allowing the juices to exude and to stand out like drops of dew" (M., 1871).

Fig. 21. These three figs illustrate the Spanish proverb about a luscious fig: a neck for the hangman, a robe for the beggar (checked skin), a tear for the penitent (drop of gum in the eye).

Checking of the skin denotes a fig ready for eating. A Spanish proverb describing the perfect fig reads: "A neck for the hangman, a robe for the beggar, a tear for the penitent; " and Mary Boyd (1911) states that the figs which she bought in Majorca had all the required attributes of perfection: "the slender neck, the rent in the skin, the oozing drop of juice." (Fig. 21.) 
Bloom: A surface character present in some figs is the bloom. Miller (1768) reported of Genoa Black that the skin "hath a purple farina over it like that on some plums." But the bloom of fruits either has no real color or is merely waxy gray, the apparent color coming from the underlying skin. Bloom, therefore, is best described by such terms as prominent, moderate, thin, delicate.

The prominent bloom of such purplish-black figs as Mission and Pas-tiliere is pruinose. Eisen wrote of Grosse Grise Bifere as follows: "Bloom a very fine violet-pearl gray extending to the cheek, but not to the apex zone from which it is separated by a distinct line, between which and the apex there is no trace of the bloom. This is the most characteristic feature of this fig." This quotation describes accurately the bloom character found in St. J ean Grise grown at Riverside and tends to show that this variety is the same as that described by Eisen.

\section{Page 65}

\section{Chapter VII 65 Fruit Characters}

Flecks: The skin of most immature figs shows numerous white flecks or spots scattered over the surface. Brookshaw (1812) stated that Malta Brown is spotted or speckled with small whitish flecks. These flecks are more important in identification of varieties than Eisen leads one to believe, as he states only that the skin "may be dotted over with light specks or large spots." The flecks vary in size from small indistinct spots to large conspicuous dots scattered more or less thickly over the surface. In Verdal Longue the flecks are often $1 \mathrm{~mm}$ in diameter. On most green figs, the white flecks persist until full maturity, then gradually fade. On deeply colored figs the flecks either become masked or are still in evidence as reddish-brown dots.

Hairs:The epidermis of most fig fruits is studded more or less thickly with unicellular, attenuate hairs interspersed with multicellular, capitate hairs (fig. 8). Varieties of figs differ markedly in the abundance and prominence of hairs on the epidermis of the fruit. Yellow Neches and Pastiliere both show very prominent hairs. A synonym of Pastiliere is Hirta Du Japon, or "hairy Japanese." The skin of Dottato is practically devoid of hairs. Abundance and harshness of the hairs can roughly be determined by rubbing the surface of the mature fruit over the tender skin of arm or cheek.

Unicellular hairs appear transparent in fresh sections of fruit; capitate hairs have a brownish coloration. Unicellular hairs are brittle and subject to injury while material is being prepared for sectioning and mounting. They stand out at right angles to the surface of the fruit, whereas capitate hairs recline at an angle of approximately 45 degrees. A capitate hair ordinarily consists of a stalk and of a four-celled body which is oblong or obovate in shape. 
Unicellular hairs of Ficus pseudo-carica arise from prominent papillae or nipple-like protuberances. Some of the epidermal cells of the papillae show a purplish pigmentation.

Hairs on fig fruits and leaves are partly responsible for irritation of the skin suffered by some fig pickers. According to Anstruther Davidson (1899), "these prickly hairs readily penetrate the flexor surfaces of the fingers and wrists, and in individuals with irritable skins a dermatitis follows in twentyfour hours . . . probably produced by the mere mechanical presence of the bristle-like hairs, as examination shows that the hair points are solid at the tip."

Meat and Pulp:The meat of the fig is that part lying between the skin and the pulp, and it may be thick, medium thick, or thin. It is generally white but is sometimes colored violet, as in first-crop Dottato and Clare figs. The rubbery texture of certain figs, such as Dottato, is partly due to the firmness of the meat. Such figs when dried often have a thick, woody meat which is difficult to process for fancy packing.

The pulp of the fig consists of the inner part of the meat, the floral peduncles, the perianth, the parenchymatous outer cell wall of the ovaries, and the seed. The parenchyma cells of the floral organs become greatly enlarged or swollen and serve as storage tissue. The flowers as they

\section{Page 66}

\section{Condit 66 The Fig}

mature may completely fill the cavity and form a solid pulp, as in most, but not all, caprified figs whether of Smyrna or of Common type. In many common figs, such as San Piero, Brunswick, and Madeleine, the mature flowers do not fill the cavity, and the pulp is therefore hollow at the center. The pulp constitutes about 83 per cent of a mature fig.

The mature pulp may be white, as in Marseilles, Osborn, and Croisic (Cordelia), or it may become somewhat amber as the fruit softens, though in the majority of figs it is some shade of strawberry. A few figs, such as Beall and Euscaire, which are purplish black externally, have an amber-white pulp*

The fact that Dottato in California and Brunswick in Texas have an uncolored pulp is another reason for their being especially good for canning and preserving, for the finished product is attractively clear throughout. The effect of caprification upon color of pulp and upon other fruit characters of common figs has already been discussed. On the basis of internal color there are two classes of caprifigs inhabited by blastophagas: (1) those like Stanford, Palmata, and several of the Maslin seedlings, which are white 
inside; and (2) those like Roeding No. 3, Samson, and Excelsior, in which the inner part of the meat and the flower stalks are violet-purple.

Coarse texture of fig pulp is indicated by large, conspicuously swollen flowers and flower parts. Eisen described pulp texture of fruits as follows: Blanche, "very juicy, finely grained"; Bontard, "usually coarse and uneven, but sometimes . . . fine-grained"; Datte Quotidienne, "thick, oily." He did not signify what was meant by "oily" pulp. At Riverside, Mission and Adriatic figs show a pulp of fine texture, while Castellana and Euscaire have a coarsetextured pulp. Some figs when mature, notably San Pedro and Dauphine, show a gelatinous consistency of juice in the pulp.

Seeds, fertile or infertile, are characteristic of fig fruits. Such seeds may be large, medium, or small, few or many, conspicuous or indistinct.

Flavor and Quality:Flavor in figs, as in many other fruits, is a difficult character to describe. Some figs, such as Mission, have a peculiar flavor which may be described, though inadequately, as a distinctive fig flavor. Dottato is sweet but lacks character. Edible figs of Ficus palmata and most of its hybrids with F. carica have a strong, disagreeable flavor making them definitely unpalatable.

Many caprified common figs and some Smyrna-type figs have a distinct acidic taste. George Lindley (1831) wrote of Nerii: "It is much the richest of its species and there is in its juice a slight degree of very delicate acid which renders it peculiarly agreeable to most palates." Starnes and Monroe said of Peau Dure: "quality very good, distinctly vinous, a very unusual characteristic with figs and rendering this variety unique." Grasovsky and Waitz refer to the pulp of M'eimi as "sour-sweet in taste" and to that of Sharrawi as "sourish in taste." California seedlings of the Ficus palmata type bear fruits which are decidedly acid in flavor. The juice of uncaprified Dottato figs in August, 1939, showed $13.2 \mathrm{mg}$ of citric acid; caprified figs of the same variety showed 14.0 mg; and a seedling

\section{Page 67}

Chapter VII

67

Fruit Characters

of Lob Injir X F] pseudo-carica, which had an especially sour taste, showed $44.3 \mathrm{mg}$ of citric acid.

Terms used in describing flavor are: sweet, rich, highly flavored, lacking 
flavor. Such terms as agreeable, exquisite, and poor, apply more to onel's opinion of quality than to flavor. Fresh figs lack any such well-defined aroma as that found in some American grapes.

Quality depends to a considerable extent upon the use to which a fruit is put. Thus, there is little disagreement over the opinion that both the Brunswick in Texas and the Dottato in California have excellent canning quality; or that the shipping quality of fresh Lob Injir, Dottato, San Piero, and Mission figs is good to very good; or that Lob Injir, Adriatic, and Mission have excellent drying quality. General terms used in designating quality in figs are as follows: poor, inferior, medium, fair, good, very good, superior, fine, excellent.

In describing fig varieties the following form (table 3) may be used, the Lob Injir being inserted as an example.

Table 3.Description Form for Fresh Figs:

VarietyLob Injir

Grower

Date

Fruit: CropMain, good

Weightav. of 12, 71 grams Sizeabove medium to large Shapeoblate Neckshort, flattened Stalkthick and short Ribsfairly prominent Eyelarge, open Scaleschaffy

Leaves: Sizelarge Lobingfive Sinusesdeep Colorgreen Surfacedull Basecordate Petioleyellowish green

Skin : Surfacesomewhat glossy Bloominconspicuous Markingswhite flecks inconspicuous Hairsharsh Texturefirm

Colorlemon-yellow, attractive B lemishesnone

Meat: Colorwhite Thickness\% inch.

Pulp: Coloramber to light strawberry Texturefairly good Flavorrich and sweet Qualityexcellent

Seeds: Numbernumerous Sizeaverage Fertile or Sterilefertile

Notes : Figs large, of fine appearance and of excellent quality, both fresh and dried. 
Variety Keys: It is safe to say that few if any botanical keys are entirely satisfactory to the systematist. If this is true of keys to species of plants, it is particularly true of keys to fruit varieties in which deviation from the norm is very common. An artificial key to assist one in the identification of fig varieties is of definite value since it practically compels the student to seek minute characters which might otherwise be overlooked. Keys to the profichi and mamme crops of caprifigs and to the two crops of edible figs have been found exceedingly useful in the study of California fig varieties. They are based on the presence or absence of fertile seeds, on skin color, neck, stalk, size, color of meat and pulp, and other minor characters.

\section{Page 68}

Chapter VIII

FIG VARIETIES

\section{VARIETIES OF THE CAPRIFIG TYPE}

In 1901 Eisen described 19 varieties of caprifigs and prefaced his list with the following statement: "As far as is known, no caprifigs have previously been described and it is to start an investigation of these varieties that the following descriptions are offered." Milco and Roeding No. 1 are the only varieties on Eisen/'s list now grown in California. Rixford (1918) described 9 varieties and Condit (1920/) 10 varieties of caprifigs. The latest and most complete publication ever put out on caprifig varieties is that by Mauri (1939), in which appear descriptions and illustrations of 16 kinds grown in Kabylia. Varieties grown in California are listed and described as follows:

Cordelia $=$ Croisic

Croisic (Synonyms: Cordelia, St. J ohn, Pingo de Mel).Croisic is a completely parthenocarpic caprifig bearing pulpy, edible fruit. It has been described by Gallesio (1820), Solms-Laubach, Eisen, and Condit (1942). Trees are widely distributed in California and sometimes mistaken for caprifigs harboring blastophagas. The variety is especially common in the vicinity of San Francisco Bay, where trees usually mature edible figs of both profichi and mammoni crops in one season. It is grown in a small way in Oregon for fresh fruit.

Profichi pyriform with prominent ribs; color greenish yellow; interior white; stamens few with little or no pollen; blastophagas generally absent.

Excelsior. Excelsior is a seedling described and illustrated by Condit (1928\&), and was once regarded as a promising variety on account of the very large 
profichi. Considerable grafting wood sold for one dollar a foot. Trees are now seldom found.

Ficus palmata. This species was introduced by Dr. F. Franceschi of Santa Barbara, and large trees are occasionally found elsewhere in Southern California. Twigs are slender with a grayish pubescence. Leaves are mostly without lobes, the margins crenate, and the blade velvety. Terminal, dormant buds are pinkish. Figs are good but small. The species is valuable mainly for earliness, for possible hybridizing, and for the abundant long-continued mammoni crop. Seedling trees are variable but generally productive of small, purple figs with long stalk, prominent neck, and white flowers. Mamme figs have stamens and abundant pollen.

Ficus pseudo-carica. This Abyssinian caprifig was introduced from Italy by Dr. F. Franceschi about 1902 and from Eritraea by the United States Department of Agriculture in 1911. W. T. Swingle in 1910 found trees in Imperial Valley bearing mamme figs containing stamens and pollen.

\section{Page 69}

\section{Chapter VIII 69 Fig Varieties}

It has been used to some extent for hydridizing. Trees are seldom found in commercial fig districts. (See Rixford and F. Heiny, 1911.) Profichi are small, purplish black outside and white inside.

Markarian (Markarian No. 2). This variety was named and widely distributed by Henry Markarian, Fresno, previous to 1910 but has largely been discarded. It was described by Condit in 1920. The tree has upright branches somewhat resembling those of Lob Injir. The internal color of the figs is white.

Maslin. Some of the seedling caprifigs in the Maslin orchard at Loomis were named and described by Rixford (1918). Maslin No. 70 became Bleasdale; No. 144, Mason; No. 147, Loomis; and No. 148, Newcastle. Ninety trees of Maslin No. 150 were planted in the Association caprifig orchard at East Orosi in 1921. The trees have a vigorous, upright habit of growth, but the profichi are not regarded as favorably as other standard varieties. All of the foregoing varieties bear large green profichi, white inside and mostly with flattened neck, indicating Lob I njir as the female parent. Maslin No. 91 bears figs purple outside and white inside. Maslin No. 77 has a purple interior. None of the Maslin varieties is now grown commercially.

Milco. According to Eisen this variety was imported from Dalmatia by G. N. Milco, but Rixford (1918) states there is little doubt that it was obtained from I taly by W. B. West under the name Verdoni and later exploited by Mr. Milco, whose name it bears. Large trees are especially common in Stanislaus and 
San J oaquin counties. It is now seldom planted. Figs are purple inside.

Mamme figs medium, spherical, without neck, and with very short stalk; color green with prominent bloom; white flecks often becoming purplish on mature fruit. Profichi medium, oblique-spherical, with short neck; color green assuming a light reddish brown at maturity; eye with pinkish scales. Season late. Mammoni figs numerous but inclined to become pulpy; color, reddish brown at maturity.

Roeding No. 1. Roeding No. 1, imported by Fred Roeding from Asia Minor, was described by Eisen in 1901 and by George Roeding in 1903. For about twenty years following its introduction it was the most widely planted of any variety because of tree vigor and ease of propagation. Since 1920 it has been superseded by better varieties. Internal color of figs is purple.

Mamme figs small, oblate-spherical, without neck; stalk very short; color green with small, conspicuous, white flecks. Profichi small to medium, spherical, with short but prominent neck; color light green; "blanks" inclined to remain on tree until maturity. Season medium early.

Roeding No. 2. Roeding No. 2, also imported by Fred Roeding from Asia Minor, was described by Eisen as Smyrna No. 2 and by George Roeding as Roeding No. 2. The tree is distinctive on account of its upright habit of growth and slender twigs. The bark is not smooth but scaly, at least on the trunk. (See Condit, 1941c, fig. 20.). It is no longer planted commercially. The figs are purple inside.

Roeding No. 3. Three varieties of caprifigs imported by Fred Roeding from Smyrna were labeled in the nursery row, No. I, No. 2, and

\section{Page 70}

Condit

70

The Fig

No. 3. No. 3 proved to be the earliest in maturing its fruit, No. 1 second, and No. 2 the latest. No. 3 was described by Eisen as Smyrna No. 3 and by George Roeding as Roeding No. 3. This is the best of the Roeding varieties and the most popular of all caprifigs now grown in California. The tree is moderately vigorous, much branched, has short slender twigs and reddishbrown terminal buds. The leaves are smaller than those of Roeding No. 1 or of Stanford. Figs are purple inside. 
Mamme crop generally good, usually consisting of two types of fruit, both medium in size, oblique-turbinate with or without short neck; figs of one type, light violet in color, with prominent ribs and somewhat soft or of spongy texture, therefore more subject to frost damage; figs of the second type, deep violet-purple, with ribs much less prominent, and texture solid or firm, containing more inhabited flowers than figs of the first type; eye commonly depressed.

Profichi above medium to large, turbinate to pyriform with a prominent thick neck and short stalk; apex broad, flattened; color light green; bloom conspicuous; white flecks prominent. Season early.

Roeding No. 4. This was probably introduced from Italy by George Roeding. There is some confusion as to its identity as two more or less distinct caprifigs are known as Roeding No. 4. Trees of both types show an upright habit of growth; both bear a good mamme crop and the profichi are late maturing. The one most commonly found produces profichi of medium size, green in color, with prominent neck commonly flattened, and with prominent ribs making the surface somewhat corrugated. Internal color is purple.

Samson (Markarian No. 1). The original California tree of the Samson is growing on the Stanford Ranch, Vina. It was probably in the lot of cuttings introduced from Asia Minor by the Bulletin Company of San Francisco in 1882. The variety was first propagated and distributed by W. H. Samson of Corning as Capri No. 5, and later by Henry Markarian of Fresno as Markarian No. 1 . The tree is moderately vigorous, exceptionally dense, and the bark of its trunk is characteristically furrowed. Terminal buds are green. Internal color of fruit is deep violet-purple.

Profichi medium, turbinate with the neck prominent and thick or sometimes tapering and up to ^ inch long; white flecks large and conspicuous; color light green; stamens sometimes rusty and unproductive of pollen. Profichi commonly affected by a mosaic spot as described by Condit and W. T. Horne (1943).

Stanford. The original California tree of Stanford, on the Stanford Ranch, Vina, was introduced from Asia Minor by the Bulletin Company in 1882. It was propagated and distributed by W. H. Samson, Corning, as Capri No. 1, in 1906. It now ranks second in popularity among commercial varieties. The tree is vigorous, spreading, with green terminal buds. Figs are white inside. According to A. Nadir and M. Halit (1929), Stanford is the same as Kara Ilek of Smyrna.

Mamme figs medium, oblique-turbinate, mostly with a short prominent neck; color green with prominent bloom; white flecks large and conspicuous. Profichi medium to large, oblique-pyriform, with distinct often curved neck; ribs inconspicuous; color light green. 
Chapter VIII

71

Fig Varieties

\section{VARIETIES OF THE SMYRNA TYPE}

Smyrna-type figs are grown mostly in Asia Minor, Greece, Algeria, Portugal, and California. Descriptions of the principal varieties follow. The P. I.

numbers refer to the Division of Plant Introduction, United States Department of Agriculture. (See Condit, 1920c.)

Bardajik. This variety name is from two Turkish words, Bardak, pitcher, and J ik, tiny. The shape of the fig resembles that of a small pitcher. The Bardajik is grown near the coast in the Smyrna district and on account of its excellent flavor is eaten mostly in the fresh state. It was introduced into California by George Roeding but proved unsatisfactory because of the serious splitting of the fruit. The fig is green in color with a dark strawberry pulp. (See H. R. Hagan, 1929\&.)

Calimyrna, or California Smyrna = Lob Injir.

Cheker I njir. Cheker I njir is grown in the southern part of Asia Minor and on the I sland of Chios. It also was introduced into California by Roeding but had no particular merit either fresh or dried. The figs are oblate with a short neck; color of skin, greenish yellow; color of pulp, strawberry.

Kassaba. Trees of this variety are reported by Roeding to be very commonly planted in the Smyrna fig district with trees of Lob Injir. Figs of the two varieties are dried together, but those of the Kassaba, distinguishable by their red pulp, are not used in fancy packs. Trees, introduced by Roeding into California, are now seldom found. The fruit is distinguished from Lob Injir by the following characters: Kassaba, eye medium, scales pinkish, pulp strawberry; Lob Injir, eye large with straw-colored scales, pulp amber.

Lob Injir (Sari Lop, Calimyrna.) This is the principal drying fig of the Meander Valley, near Smyrna. It has been imported several times into California where it was given the name Calimyrna as the result of a $\$ 25.00$ prize offered by George Roeding for the best name for the variety in its new environment. Lob Injir commonly produces a few brebas, which are large, golden-yellow in color, have amber pulp, but are insipid in flavor. In Asia Minor, according to Hagan (1929\&), the name Yel Injur, meaning "wind fig/ $\backslash$ ' is applied to the first crop. 
Figs of the main crop large, oblate, with short stalk, and short, flattened neck; ribs fairly prominent; eye large, open; surface somewhat glossy with delicate bloom; color greenish yellow to light lemon yellow, attractive; pulp amber to light strawberry; flavor rich and sweet; quality excellent both fresh and dried; fertile seeds numerous. Principal defects are large eye and tendency to split.

Stanford. Accounts of this variety have been contributed by Rixford (1920) and by Condit (1922a). It is one of the varieties included in the original importation by the Bulletin Company. Trees were widely distributed in San J oaquin Valley orchards, but growers have gradually eliminated them by topworking to Lob Injir. The trees do not bear so heavily as Lob Injir trees even though they are more vigorous in growth; the figs are smaller than Lob Injir and have green skin and strawberry pulp. Leaves

\section{Page 72}

\section{Condit 72 The Fig}

of Lob Injir are clean cut, the lobes having entire or shallowly crenate margins; leaves of Stanford have lobes with lyrate margins.

Tameriout. Mauri reports this as one of the best figs of Algeria, especially near Bougie. The fruit is pyriform with a somewhat elongated neck, light green in color, and has strawberry pulp. It is of good quality both fresh and dried.

Taranimt. According to Mauri, Taranimt is the principal commercial variety of Kabylia. Figs are large, pyriform with prominent neck, green or yellowish green in color, and have strawberry pulp. In quality it ranks second to Tameriout.

\section{VARIETIES OF THE SAN PEDRO TYPE}

Brebas of the San Pedro type are, like common figs, parthenocarpic in development. Second-crop figs drop unless caprified. Few figs of this type are grown commercially. Descriptions of the most important varieties follow.

Adam $=$ Dauphine

Blanquette. Blanquette was introduced from Morocco in 1933 under P. I. No. 102007. It may prove to be identical with Blanche $d$ ' 'Argenteuil although that variety is reported to bear two crops of common figs.

Breba crop good; figs medium to large, pyriform with prominent, slightly flattened neck; eye large, scales chaffy; color green; pulp strawberry, quality 
fair. Second-crop figs medium or above, spherical to somewhat oblate; color green; pulp strawberry.

Dauphine (Ronde Violette Hative, Adam, Pagaudiere). The Dauphine is commonly grown at Argenteuil near Paris for the fresh fruit market. It came to California in the Chiswick collection as P. I. No. 18912 but has not been planted commercially.

Breba crop good; figs medium to large, broadly turbinate, with short, thick neck and short stalk; eye large, open; surface glossy with pruinose bloom; color violet-purple; meat thick; pulp strawberry; quality good. Second-crop figs medium, oblate, mostly without neck, similar to brebas in other characters; quality fair to poor.

Gentile.The history of the Gentile in California is given by Eisen (1901, p. 69). It was introduced in 1852 at San Leandro. A tree planted in 1886 on the Kimball place, Hay ward, is still producing a breba crop each season. It is adapted only to cool coastal sections. In England it is described as a late fig, spherical in shape, and both skin and pulp yellow in color. Brebas in California are large, spherical, with green skin and light strawberry pulp.

King. This variety has been widely distributed and planted in Pacific Coast states during the past few years. In cool coastal sections, brebas, maturing in J uly, are of large size, have green, glossy skin, violet meat, and light strawberry pulp. The second crop fails to set and mature in most districts unless the figs are caprified.

Lampeira. According to Eisen this variety is common in northern Italy and in southern Portugal. He concludes: "What the White San Pedro is for Andalusia in producing the luscious brebas the Lampeira is for southern Portugal." It may be identical with Figo Burro, or Lampo,

\section{Page 73}

Chapter VIII

73

Fig Varieties

described by Bobone (1932). Brebas are large, roundish-pyriform, have greenish-brown skin and rose-colored pulp. Trees were once established at Niles, California, but the variety has since been lost, unless it exists under another name.

San Pedro (White San Pedro). Various other synonyms are given by Eisen, 
who states that this variety has been introduced into California at various times, once from Spain under the name "Breba."

It has not been planted commercially to any extent.

Brebas medium to large, turbinate to spherical, with short, thick neck and short stalk; eye medium, open; surface glossy; color green; pulp light strawberry; flavor insipid; quality fair. Second-crop figs are similar to brebas but generally without neck; pulp somewhat gelatinous; quality poor whether fresh or dried.

\section{VARIETIES OF THE COMMON TYPE}

Fig varieties of the Common type probably outnumber those of all other types put together. The following list includes only the more important varieties and those with well-established identity.

Adriatic (White Adriatic, Verdone, Nebian, Grosse Verte). The Adriatic is probably of Italian origin. It has long been grown in England under the name Grosse Verte. As long ago as 1868, Barron described it as one of the largest, handsomest, and richest-flavored figs in cultivation. It was introduced into California in 1865 and gradually became the leading commercial variety for drying. The tree is vigorous in growth and develops into a broad, roundtopped, dense head. Condit published an account of the Adriatic in 1920.

Breba crop small; figs large, oblique-pyriform; color green often with a tinge of violet from the colored meat; pulp dark strawberry; flavor strong.

Second crop good; figs medium, variable in shape but generally turbinate with short, thick neck, and short stalk; eye medium, open, with chaffy or sometimes pink scales; color green to yellowish green; pulp strawberry, blood-red when caprified; fig flavor distinct; quality good to excellent. Figs grown in cool coastal districts, large, dark green, with dark strawberry pulp.

Beall. This chance seedling originated in the Santa Clara Valley and fruited on the W. A. Beall place near Fresno about 1924. The tree bears two crops. The figs are unusual in having a purplish-black skin and white pulp. Tests so far made indicate excellent quality in desert valleys and in warm coastal districts of southern California.

Black Spanish $=$ San Piero

Blanche (Blanche $d \backslash$ 'Argenteuil). Apparently the fig grown extensively at Argenteuil for the French market has not been widely distributed, at least under these variety names. According to Eisen there are two crops of greenish-yellow figs with amber pulp. As far as known, it does not occur in California. 
Bourjassotte Grise. This fig has long been highly regarded for culture in England, especially for forcing in pots. It was one of the best in the collection at Chiswick, from which it was imported into California as No. 18847. Trees are now rare in this state as the fruit drops badly while small. Apparently it does best in cool climates. The breba crop is small or missing.

\section{Page 74}

\section{Gondit}

74

The Fig

Figs medium, oblate-turbinate with short, thick neck and short stalk; eye medium, open; color greenish violet; bloom prominent; pulp dark strawberry, hollow at the center; quality fair to good.

Bourjassotte Noire (Barnissotte). This French variety, long grown in England, was introduced into California in the Chiswick collection as No. 18840. Barnissotte was received in 1926 as No. 69009. It is not grown commercially.

Breba crop very small or none; figs large, purplish black. Second-crop figs medium to large, turbinate; neck either absent or short and thick; stalk short, loosely attached to the twig; eye medium, open; surface somewhat glossy with prominent bloom; color purplish black, with green color persisting at the apex in some specimens; pulp strawberry; quality of fresh figs good, of dried figs poor.

Brown Turkey. Brown Turkey is regarded by English gardeners as by far the best fig in cultivation either for standard trees out of doors or for forcing under glass. W. Coleman published a description and color plate of Brown Turkey figs in 1880. According to Bunyard (1934) more trees of this variety are planted in England than of all other varieties put together, owing to its hardiness and productivity. It has been introduced into California but its identity is in doubt. Bunyard describes the fruit as medium to very large on old trees; color chocolate-brown; surface slightly ribbed; pulp deep red; flavor sweet and rich.

Brown Turkey of California $=$ San Piero

Brown Turkey of eastern United States. Next to Celeste this is the variety most widely planted in the southern and eastern states. The tree is hardy and prolific, often producing two crops in one season. The figs are of medium size, broadly pyriform, coppery-brown in color, and have light strawberry pulp. 
Brunswick (Magnolia, Madonna). Brunswick was commonly grown in England as early as 1768 when Miller described it as a long pyramidal fruit, with brown skin, coarse texture, and little flavor. J ohn Lindley described and illustrated Brunswick in color in 1841. The identity and nomenclature of Brunswick has recently been reviewed by Condit (1941b). Confusion regarding the variety is partly due to the fact that English authors commonly describe and illustrate figs of the first crop, but in California and Texas, horticulturists deal mostly with the second-crop fruit. Brunswick, under the name Magnolia, forms the basis of the preserved-fig industry of Texas. Trees are commonly found in eastern states and some are bearing in sheltered places in Washington, D. C. In California the trees are dwarf and unproductive unless given an abundance of water. Leaves have narrow lobes.

Breba crop generally poor; figs large, oblique-turbinate; eye medium, open; color bronze; pulp light strawberry, coarse. Figs of the main crop, medium, mostly without neck; stalk thick, often prominently swollen; eye medium, open; color bronze or violet-brown; pulp amber, almost seedless, hollow at center; quality fair.

Castle Kennedy. The identity of this variety is not certain. It takes its name from Castle Kennedy, Wigtownshire, Scotland, where it has long been grown. In England it is generally described as a shy bearer; the fruit resembles very much that of Brunswick. In South Africa the second crop

\section{Page 75}

Chapter VIII

75

Fig Varieties

is said to require caprification. Two recent introductions into California, one from France as P. I. No. 69017, the other from Morocco as No. 102015, have both proved to be identical with Brunswick.

Celeste. Celeste has not been certainly identified with any European variety although it may be the same as Malta, described by Hogg (1866). On account of hardiness of tree and resistance of fruit to spoilage, it is the most widely planted variety in southeastern United States. There are few commercial plantings, however. Trees produce no brebas.

Figs small, pyriform, with or without short neck; stalk slender, up to 24 inch in length; eye small, partly closed; bloom conspicuous; color bronze tinged with violet; pulp rosy-amber, almost seedless; flavor rich; quality good; dries 
well on the tree in California.

Clare (Dr. Hogg\'s Clare). This variety came to California with the Chiswick collection as No. 18878. It is noteworthy on account of its excellent breba crop. The green-colored figs blend so well with the foliage that birds do not readily find them.

Brebas medium to large, oblong-pyriform, with thick neck; color green commonly flushed with violet from the colored meat; pulp deep strawberry; flavor rich and sweet; quality excellent. Second-crop figs medium to small, pyriform; neck short, sometimes flattened; eye medium, open; scales tinged with violet; color green; pulp strawberry; quality fair.

Col de Senora Blanca (Col de Signora Bianca, Fraga). This variety, both fresh and dried, is popular in Spain. A description and color plate of the fruit is found in Florist and Pomologist for 1878, page 121. In California it is rarely seen; the figs appear to be not so good for drying as the Adriatic. The tree bears no brebas.

Figs medium, spherical to turbinate; neck thick and short; stalk short; eye rather large, open; scales flesh color or sometimes pink; surface somewhat glossy; color greenish to lemon-yellow; pulp dark strawberry; quality fair. A dark-colored variety, Col de Signora Nero, is somewhat resistant to spoilage in Spain.

DI' Ag e $n=$ Verdal Longue.

Dottato (Kadota, White Pacific, White Endich). Dottato is the principal drying fig of southern Italy where it has probably been grown for centuries. It may be the same variety which Pliny said was brought by Lucius Vitellius from Soria to his villa at Alba. The name comes from the Italian fico addattato, or adapted fig, undoubtedly referring to its wide adaptability to soils and climatic conditions as well as to possible uses. The literature on this fig, its history, culture, and uses has been reviewed by Condit in 1920 and 1927. In California it forms the basis of the canned fig industry and is also marketed both fresh and dried. The tree bears two crops.

Brebas large, pyriform with a distinct, thick neck; color green or yellowish green; meat and pulp violet tinted, sweet and rich; quality excellent. Figs of the second crop medium, spherical to short-pyriform; stalk up to $\$ 4$ incn long; eye medium, closed by scales, often sealed with a drop of clear gum; skin greenish yellow to lemon-yellow; pulp amber, almost seedless, sweet but lacking character. In cool coastal districts, figs pyriform, grass green, with violet-tinted meat and pulp.

Douro Black = San Piero. 
Condit

76

The Fig

Drap dl 'Or (Royal Vineyard, Peau Dure). The variety name, literally "Cloth of Gold," graphically indicates the external appearance of this golden-brown fig, well described by Eisen. A description and color plate of Royal Vineyard are given by Barron (1871). Royal Vineyard, No. 18849, and Peau Dure, No. 18838, of the Chiswick collection are both identical with Drap dl 'Or. At Riverside a large percentage of second-crop figs drop when small. Those that do mature are of excellent appearance and quality, especially when caprified. The tree lacks vigor but produces two crops.

Brebas large, oblique-pyriform, bronze in color, with prominent ribs, and rich, strawberry pulp. Figs above medium to large, turbinate with a very distinct neck; stalk y2 inch long; ribs distinct and unusually prominent; color mahogany-brown; pulp strawberry, sweet and rich; quality excellent. I'

Du Roi. Eisen describes Du Roi as a medium, rounded-pyriform fig, of green color, with rose-amber pulp, and adds: "It is a most excellent fig and one of the very best grown in California . . . and will no doubt become one of the most extensively grown $\wedge$ ' No trees of this variety can now be located.

Figue dl 'Or (De la Madeleine, Angelique). In the Chiswick collection brought to California, Figue dl 'Or, P. I. No. 18880 and Madeleine, P. I. No. 18890 proved to be identical. According to Barron (1868\&) this variety is one of the earliest in cultivation and is distinguishable from others by its beautiful, clear yellow fruits. In interior California it is practically worthless on account of its susceptibility to souring.

Brebas few, medium or above, turbinate; stalk somewhat enlarged at apex; eye large, open; surface glossy; color lemon-yellow; pulp very light strawberry; center hollow; quality fair. Figs similar to brebas though smaller, oblate-spherical without neck; quality poor.

Frag $\mathrm{a}=$ Col de Senora Blanca.

Genoa (Genoa White). Miller in 1768 wrote that this fig is good but that the trees are shy bearers. Other English authorities agree with this appraisal of the variety. It has long been grown in California but only as a dooryard tree and is apparently one of several which are practically worthless in the hot interior but excellent in cool, coastal districts. The tree bears two crops. Dormant buds are not green, but tawny. 
Brebas large, oblique-obovate, with thick neck and short stalk; eye medium, open; color yellowish green; pulp light strawberry; quality fair to good. Figs of second crop above medium, turbinate; neck missing or very short and thick; eye rather large, open; scales flesh color to pink; skin greenish yellow; pulp hollow, amber tinged with strawberry; quality fair.

Grosse Verte $=$ Adriatic

Hirta du J apon $=$ Pastiliere

Hunt. Hunt is a seedling developed by B. W. Hunt in Georgia. The figs are similar in fruit characters to Celeste but are larger and hang downward on a long slender stalk. It has no commercial possibilities in California.

Ischia Black. In 1768 Miller described Black Ischia as a highly

\section{Page 77}

\section{Chapter VIII}

\section{7}

Fig Varieties

flavored fig. Brookshaw (1812) illustrated it in color. Barron in 1868 wrote as follows regarding Black and White Ischia: "What authority Miller had for these names is not known. It is more than probable that he destroyed the Italian names which he had received with them, and substituted these in their place a practice far too prevalent at the present day and one which cannot be too severely condemned." Bunyard (1934) gives this variety as a dark form of White Ischia with "the fruit a little more peg-top shaped." He includes both Black and White Ischia among varieties for the epicure.

In California, Ischia Black cannot compete with Mission on account of the smaller size of the fruit. The leaves are different from those of the Mission in having a glossy surface and a truncate base. The tree bears two crops. The small figs start coloring early, have an elongated stalk often swollen at the apex, and are purplish black when mature.

Ischia Green. This variety name occurs in horticultural publications of England as a synonym of White Ischia, but as grown in the United States it is a different variety. Bernard M 'Mahon described it in 1857 and several later writers tell of the fruit and its culture in the southern states. Specimens recently fruited in California show a fig below medium to small, with prominent, flattened neck, green color, and dark strawberry pulp. Season late. 
Ischia White. Ischia White has long been grown in England. Barron (1868c) wrote that "the little White Ischia is very fickle in respect to quality; the fruits of today are excellent, of three days hence watery and tasteless." Trees are common in California but are gradually disappearing in favor of better varieties. It has no advantages except prolificness. Trees are densely branched and have small 3- to 5-lobed leaves.

Breba crop is small or absent. Figs small, spherical to oblate, mostly without neck; stalk up to 24 inch long, often swollen at the apex; eye medium with scales pink or flesh color; color green flushed with brown; pulp light strawberry; flavor sweet, rich; quality fair; dried figs meaty and good but small.

Kadota $=$ Dottato

Lemon $=$ Marseilles

Madeleine $=$ Figue $d \mathbf{l}^{\prime}$ Or .

Magnolia $=$ Brunswick

Marseilles (White Marseilles, Lemon). Marseilles is probably of French origin. It is illustrated in color by Brookshaw (1812) from fruit grown in the garden of the Episcopal Palace at Lambeth, England. In England the tree grows well in pots or as an outdoor standard and bears both a first and second crop. The following three varieties were included in the Chiswick collection and proved to be identical to Marseilles: Figuier Blanche No. 18904, Vigassotte Bianco No. 18864, and Quarteria No. 18866. It is of no commercial value in California.

Breba crop small; figs medium, turbinate with short, thick neck and short stalk; eye medium, open; flecks small, green; color yellowish green; pulp white; seeds large, conspicuous. Figs of second crop much the same as brebas; spherical to oblate, without neck; stalk slender up to $Y^{*}$ inch long; quality fair.

\section{Page 78}

Condit

78

The Fig

Mission (California Black). The Mission fig is so called because it was the first 
variety planted in California by the Mission fathers. This was in 1769; trees were subsequently widely distributed throughout the state. It is still the leading commercial variety of black fig and is highly regarded both fresh and dried. It is found in Granada and Malaga provinces of Spain as Brebal. In the Chiswick collection, Biberaeo No. 18875 and Reculver No. 18868 are identical with Mission. The tree bears two crops. Terminal buds are brown. (See Condit, 192/fr.)

Brebas large, oblique-pyriform, with distinct neck; color purplish black; pulp strawberry; fig flavor distinct, rich; quality excellent. Figs medium, oblong, mostly without neck; stalk short; eye small, fairly well closed; bloom conspicuous; color and pulp same as brebas; quality excellent.

Osborn $=$ Ronde Noire

Pagaudiere $=$ Dauphine

Panache. An account of this striped fig, or chimera, is given by Condit (1928a). Apparently it is a variegated sport of Col de Signora Bianca, the fruit of which it closely resembles except for the skin, which is beautifully striped with green and yellow bands. The fruit was described and illustrated in color by Barron in 1869.

Pasquale (Natalino). According to Eisen this fig is very late, withstanding frost at Naples and ripening after the leaves of the tree have fallen. At Riverside the Pasquale tree had dropped all leaves by December 28, 1944, but was still loaded with small, purple, oblate figs in various stages of maturity. On account of cool weather the figs were of poor quality.

Pastiliere (Hirta du J apon). This variety is seldom mentioned by horticultural writers in England. It appeared in California variety lists as early as 1890; in the Chiswick collection it was included as No. 18888 and Hirta du Japon was No. 18857. Eisen (1901) stated: "If the writer could plant only one blue variety it would certainly be this fig." What little success it has achieved since that time has been along the coast, especially at San Diego. Farther inland it is of little value. The tree is dwarf in habit with prominent nodal swellings on branches. It bears no breba crop. In Texas, and sometimes in California, Pastiliere figs drop prematurely.

Figs medium, turbinate, or spherical, mostly without neck; stalk up to one inch long; surface hairy or pubescent with prominent bloom; color purplish black; pulp strawberry; flavor insipid; quality fair. Season early.

Peau Dure $=$ Drap d ${ }^{\prime}$ 'Or.

Pied de Boeuf. This fig, described by Hogg and Eisen, is very similar to Drap d I'Or. At Riverside it matures two crops of large, brown figs with amber pulp of good quality. In longitudinal section it does have a resemblance to a 
miniature "neat/'s foot."

Ronde Noire (Osborn Prolific). The name of Osborn Prolific is due to the introduction of this variety into England by Mr. Osborn of Fulham in 1878-79. Some English horticulturists report Osborn Prolific and Brown Turkey to be identical. Eisen reported Ronde Noire entirely distinct from Osborn. In California, Ronde Noire is a worthless fig in the

\section{Page 79}

Chapter VIII

79

Fig Varieties

interior valleys. In cool coastal districts the figs are large and of excellent quality. The tree bears two crops.

Breba crop small; fruit large, oblique-pyriform, purplish brown with amber pulp. Figs above medium, turbinate with broad apex and thick neck; color greenish violet; pulp amber with few seeds; texture dry; quality poor in interior valleys.

Royal Vineyard = Drap dl'Or.

St. J ean (Grise de St. J ean, and probably Grosse Grise Bifere of Eisen) .

St. J ean was obtained from a French nursery in 1926 under P. I. No. 69015. It has proved identical with Grise Madeleine No. 86806 and Grise Savantine No. 18865 of the Chiswick collection. It has no commercial importance in California but is an excellent fig for home use. The tree lacks vigor, probably due to a mosaic disease, but bears two crops over a long season.

Brebas and second-crop figs similar in characters. Figs small, spherical to obovate, mostly without neck; stalk short; surface dull; bloom prominent on body, absent from apex; color a delicate violet-gray, attractive; pulp strawberry; flavor sweet, rich; quality excellent.

San Pedro Black = San Piero.

San Piero (Brown Turkey of California, San Pedro Black, Negro Largo, Aubique Noire, Douro Black, Black Spanish, Negro dl 'Espagne).

The confused nomenclature and the identity of this variety have recently been discussed by Condit (1944). Gallesio in 1820 described the San Piero as 
common in Tuscany and added nine other locality, or variety, names. It is widely distributed in southern Europe, has long been grown in England, and is commonly grown in California. In the southern United States it is known as Brunswick. Few if any other figs will produce as large a tonnage of fresh fruit per acre as San Piero. The trees thrive under a system of heavy pruning, the fruit on the vigorous sucker wood being of extra large size. Trees are seldom found in the San J oaquin Valley for the figs are of no value when dried and the fresh fruit is very susceptible to insect infestation and souring. Two crops are produced.

Brebas and second-crop figs are similar in fruit characters. Figs large, obliquepyriform, generally with short, thick neck; stalk short; eye large, open; eye scales colored pink even on green, immature fruit; white flecks large, scattered; color violet-brown to purplish black; pulp strawberry with hollow center; quality of figs ripened on tree very good.

San Pietro. A fig long grown by the late Leroy Nickel of Menlo Park under the name of San Pietro, can be highly recommended for coastal districts of California. The tree bears two crops of large, elongated, green figs having strawberry pulp and excellent quality.

;Troiano (Trojano). Troiano was described in Italy as early as 1583 by Giovanni Porta, who stated that Pliny called it Serotina. Later Italian writers agree that it is the favorite variety of the Naples district for fresh fruit. It was introduced into California as early as 1890 but has seldom received favorable comment. The tree produces no breba crop.

Figs below medium, obovate, with or without short neck; stalk slender up to y1 inch long; eye large, open, with brightly colored scales; color yellow; pulp strawberry ; quality fair; not suitable for commercial canning on account of the colored pulp.

\section{Page 80}

Gondit

The Fig

Vtfrdal Longue (Dl'Agen). This is apparently a French variety long grown in England and introduced into California as No. 18870 under the name D I'Agen. The tree bears no brebas but does produce a prolific crop of late figs which continue to ripen as long as weather permits.

Figs medium or above, obovate with short, thick neck and short stalk; eye medium, open; scales chaffy, tinged with violet; skin checking crisscross at maturity; bloom prominent; color green tinged with violet; pulp dark 
strawberry; flavor rich; quality good.

\section{SELECTED LIST OF FIGS}

The following list of and uses in California.figs is suggestive of varieties for special locations

Adriatic Lob Injir (Calimyrna)Figs for drying Mission Dottato (Kadota)

Mission Dottato Verdal LongueFigs for fresh fruitinterior valleys Lob Injir Beall San Piero

Ronde Noire San Piero San PietroFigs for fresh fruitcool coastal districts Genoa White King Adriatic

Beall Genoa Ronde NoireFigs for fresh fruitmild southern coast Verdal Longue Mission San Piero

Mission Ischia Black BeallGood black figs San Piero Barnissotte Marabout

Dottato Calimyrna Verdal LongueGood green or yellow figs Clare Adriatic Ischia Green

St. J ean Celeste HuntGood bronze or violet figs Brunswick Ronde Noire Pied de Boeuf

Dauphine Blanquette Clare MissionGood figs for breba crop San Pedro White King San Piero San Pietro

Dottato CelesteGood figs for canning or preserving Marseilles Brunswick

\section{Page 81}

Chapter IX

SOME FIG DISTRICTS OF THE OLD WORLD

Commercial fig culture is practiced in all the countries bordering the Mediterranean Sea, but in none of these, with the possible exception of Portugal, does the fig stand first in importance among the fruits grown either for home consumption or for export. For example, exports of raisins from Izmir (Smyrna) surpass those of dried figs. In Spain the monetary value of the almond, olive, orange, and grape crops each exceeds that of the fig crop. On an export basis the six leading fig countries are in order of importance, 1920-1938, Turkey, Greece, Italy, Algeria, Spain, Portugal. See Table 4 for 
production figures. The fig industry of each country will now be considered.

Turkey:The fig and its culture in the Izmir district of Turkey has been discussed by Eisen (1901), Roeding (1903), Condit (1924a), L. A. Wheeler (1927), A. Nadir and M. Halit (1929), Hagan (1929), and P. M. J ukovsky (1933). Commercial fig orchards are found mainly in the two valleys southeast of Izmir; the smaller valley is drained by the Cayster River, the larger one by the Meander River (fig. 22). The government-owned railway reaches both valleys and passes through a coastal fig district near Ayassouluk, the ancient city of Ephesus. Some figs are grown also in the Hermus Valley, east of Izmir in the vicinity of Kasaba and Maghnisa. The best dried figs are produced between Baladjik and Aidin on the north slope of the Meander Valley at the eastern end of which new plantings of figs were made about 1928. An average orchard contains 300 to 400 trees planted 35 to 50 feet apart. The owner lives in town and may operate several orchards considerable distances apart.

Table 4.Production of Dried Figs in Mediterranean Countries:

YearAlgeriaGreecel talyPortugalTurkey

tonstonstonstonstons

Average

$1938-4218,70025,00093,2008,40032,800$

$1933-4218,00022,90083,8006,40033,900$

Annual

$194020,80031,900107,4007,70032,000$

$194118,60023,10080,20011,00038,500$

$194214,80020,90085,4008,80019,800$

$1943117,20016,50066,00012,10027,500$

$1944120,90013,20088,0009,40033,000$

1 Estimated.

Table from figures by W. R. Schreiber (1945a), Marketing Specialist, Office of Foreign Agricultural Relations, United States Department of Agriculture. Spain is omitted from the table as reliable statistics for that country are lacking. 
yjm\&trLnKaa.

JK_

IIU

]\%

Try

$\&[[1$

yTrf

B*Uamba.I D*jh

$\mathrm{n}^{\wedge} \mathrm{rrrp}^{\wedge} \mathrm{TCT}^{-}$

Smyrna

\%miie.\&

of.

in

*T

rrpw/fT 'Tfl'-

JuW

$? \mathrm{e}^{\wedge} \$ \&-$

J*

;iW

n

$\left.x\right|^{\prime}$ 


\section{$\left.\mathrm{W}^{*}\right|^{\prime * *} \mathrm{~W}$}

yrrmtn

$\mathrm{N}$

//TTX

ハ'"'ハ'On..,

\section{/ J f*mmt||m||HtxyXHxW|}

Fig. 22. Map of the Smyrna fig district. (Adapted from map by H. R. Hagan in California Dept. Agr. Mo. Bulletin 18(9): 494. 1929.)

\section{Page 83}

\section{Chapter IX 83 Fig Districts}

The climate of the Meander Valley seems especially well suited to the production of thin-skinned and fine-textured dried figs. The summers are dry and hot with maximum temperatures ranging up to $1080 \mathrm{~F}$. Hot, dry winds coming from the north in J uly hasten fruit maturity. In August the direction of the wind changes. Coming from the west and bringing some humidity, it causes lower temperatures and prevents excessive drying of the figs. The annual rainfall, coming between October and May, varies from 21 to 29 inches. The orchards are not irrigated. Lob I njir is the principal drying variety but Bardajik is grown in coastal districts for its fresh fruit. Both require caprification, the caprifigs being secured in the neighboring hills or in certain sections, such as Shamli and Kemer, where the trees are exceptionally productive.

The harvest season begins the first week in August and continues until the first of October. The figs drop naturally from the trees and are picked up once or twice daily. In the drying yards the figs are spread on reed or straw mats one layer deep, and are turned by hand during the drying process of three or four days. When dried, the figs are sacked and shipped to Izmir where they are sorted into five grades according to quality. Hagan specifies these grades to be approximately as follows:

Suzme grade: figs large, white, of excellent flavor, high sugar content, without blemishes.

EUeme: selected figs, same as Suzme but smaller. 
Patchal: mixed figs, theoretically consisting of all qualities; sometimes separated into "firsts" and "seconds".

Naturel: small figs with thick skin, coarse pulp, blemishes, birdpecks, and dirt.

Hourda: cull figs unfit for food, used for alcohol and other byproducts.

The average fig crop of twenty years ago yielded 18 per cent Suzme, 35 per cent EUeme, 35 per cent Patchal, and 12 per cent Hourda. The percentage of Suzme and of Elleme is now considerably lower and that of Patchal is higher. Several thousand workers depend upon employment in the fig "hans," or packing houses, for much of their livelihood, and the arrival each season of the first dried figs in the city of Izmir is a welcome occasion. Sorting in the hans is done by women who keep their hands moistened with salt water or sea water. Actual packing was once done by men, but women are gradually superseding men for this kind of work. The Director of Sanitary Affairs publishes a set of regulations to govern conditions among the workers in the hans and sees that they are enforced.

The finest pack is the Locoum, in which the figs are pressed whole without steaming or sterilizing into a rectangular form that leaves little if any space between them. The Macaroni pack has long been used for whole figs packed in rows, with the stem turned under and the upper edges not overlapping. The Protoben pack is so called from the names of two men who first used it and is like the Macaroni, except that the undersides of the figs are pressed out concave so that one fig overlaps

\section{Page 84}

\section{Condit 84 The Fig}

the next. Layer figs are those split and pressed into boxes or cellophane packages. The Umbrella pack designates layer figs packed in long narrow boxes for display purposes\'. The packing of layer figs in boxes,

*pCcrtanzaro Ccrtonia

$* \mathrm{q}$,G-erace

IIMalta

Fig. 23. Commercial fig districts of Italy, of greatest importance.)

(Crosses denote approximate areas

including the Umbrella pack, has dwindled to almost nothing, for the markets 
prefer packages wrapped in cellophane or other transparent material. The labeling of layer figs as 3-crown, 4-crown, et cetera, up to 9-crown, refers to the spread of the flattened fruit in inches, a 4-crown pack spreading 2 inches and an 8-crown spreading 3 inches. The term "crown" has fallen into disrepute because of its indiscriminate use and abuse by various packers and exporters.

\section{Page 85}

\section{Chapter IX}

\section{5}

Fig Districts

Preparation of figs for market is in the hands of ten or fifteen firms in the city of Izmir. The dried fruit is obtained by packersl' agents either direct from the producing districts or on the bourse, or bazaar, after its arrival in the city. The average commercial production of dried figs in the Izmir district for the period 1934-1938 was 35,660 short tons. Exports were destined principally to Germany, the United Kingdom, France, and Austria.

Italy: Practically all Italian fig culture is carried on south of Naples and is specialized in certain favorable districts. Publications describing the fig industry of certain districts are as follows: A. Pellicano (1907) for Gerace, G. Guglielmi (1908) for Lecce, F. Portale (1910) for Mistretta, F. de Rosa (1911) for Salentine figs near Otranto, A. Sinis-calchi (1911) for Salerno, and E. Ferrari (1912) for Cosenza. Other general accounts are by Eisen (1901), Vallese (1909), Ravasini (1911), Condit (1924d), and Wheeler (1927). For export purposes the fig industry is almost entirely confined to the following localities named in the order of their importance: Lecce, Bari, Cosenza, Catanzaro, Salerno. Fig culture is of minor importance in Sicily compared with the culture of such fruits as the lemon, almond, olive, or grape (fig. 23).

The Cosenza fig district is located in a valley separated from the sea-coast by a range of mountains. The summer temperatures are therefore somewhat higher and the humidity lower than at points on or nearer the coast. The orchards are mostly on hillsides and practically all are intercropped with cereals or vegetables. In the vicinity of Lecce inter-planting of figs and olives is a common practice, but in the neighboring districts of Mesagne and Francavilla, fig orchards are of one variety, the Dottato, planted in regular rows. Many Italian fig plantings are not operated by the owners but are rented out to farmers who pay rental in cash or with a share of the crop.

Fig varieties of Italy are almost all of the Common type. Troiano is the most popular fresh fig of the Naples district, while Dottato is the principal drying fig 
for commercial plantings farther south. Many other varieties are mentioned or described but are found only in small plantings. Dottato figs in the Cosenza district are dried whole. In Lecce and other coastal districts the figs are picked from the tree at full maturity and cut into halves lengthwise leaving a slight attachment at the apex or eye. The figs are then spread out on trays, open side up, and dried in the sun. When exposed on the trays in this way, the amber pulp of the uncaprified figs contrasts strongly with the strawberrycolored pulp of the caprified specimens, the latter giving mute evidence that blas-tophagas are colonized somewhere in the vicinity.

Packing houses in Italy do not devote their entire attention to dried figs but handle other seasonal products such as grain, leather, almonds, and fresh fruits. Some figs are packed whole at Agropoli for export trade. In the Lecce district, figs are commonly packed by pressing the open halves of two figs into a sort of double fig. At Cosenza, the dried figs are cut open and pressed out into layers. Baskets made of chestnut

\section{Page 86}

\section{Condit 86 The Fig}

wood, willow, straw, or reed are used for containers. Baskets of straw, the cheapest material available, hold 66 to 77 pounds of figs, while reed baskets hold 33 to 55 pounds each. In packing first-grade fruit, it is a common practice in all districts to press an almond into the pulp of each split fig and to bake the product in ovens with heat sufficient to caramelize the sugar. The figs are then packed in baskets with a liberal sprinkling of fennel seed, some cinnamon bark, and bay leaves. The percentage of low-grade or cull figs varies from year to year, being especially heavy in seasons such as 1923 when about one half the crop was ruined or reduced in grade by early rains.

Italy probably ranks second to Spain in the production of dried figs. The average production in the years from 1933 to 1942 was 83,800 short tons. Exports in the period 1921 to 1924 averaged 21,550 tons per year but dropped below 10,000 tons average from 1935 to 1938.

Greece: English or French publications concerning fig culture in Greece and translations of Greek articles are few in number. Brief accounts are given by Eisen, Condit (1924\&), Wheeler (1927), and Socrates Kaloyereas (1930). In 1929 the fig acreage of Greece was reported to be 20,494 or only 2.23 per cent of the total area planted to fruit trees and vines. In comparison, olives comprised 41.7 per cent of the orchard area. The gross income from an acre of figs was about the same as that from an acre of olives, but less than one third that from an acre of currants. The fig industry is largely centered in the Provinces of Messenia and Laconia although some dried figs are produced on the Cyclades, Mitylene, Lesbos, and other islands. In 1925 Messenia produced 12,435 tons, Laconia 3206, and Larissa 666 tons of dried figs. 
The fig orchards near Kalamata, the principal packing and export city, are largely located on terraced hillsides. The trees are planted separately and only occasionally interplanted with grapes or currants. Fertilization is rarely practiced. The annual rainfall varies from 34 to 48 inches and no irrigation water is added to the soil. Showers in August or September are not infrequent and sometimes cause material damage. For example, early rains in 1922 not only damaged the quality of figs but reduced the quantity available for export by 20 per cent. Only one variety of fig is grown commercially, the Messenia, or Kalamata. It is a medium fig, yellowish green in color, has tough skin, fair quality, and requires caprification.

Since 1929 there has been in existence a government organization called the "Office for Protection of Greek Figs," which is concerned with certain problems of the fig industry. W. R. Schreiber (1945a) reports:

One of these problems had to do with United States sanitary requirements. Greek figs were not sterilized and therefore did not meet United States standards. The Protection Office arranged to install sterilization plants and by 1939 had a total of 21 such plants in operation. In addition, an American inspector was maintained to check on processing to assure that the pack would meet United States standards. Finally, realizing that the export market would be seriously threatened, if not lost entirely, to

\section{Page 87}

\section{Chapter IX 87 Fig Districts}

producing countries practicing sanitary packing methods, regulations were put into effect making it unlawful to export unsterilized figs to any country.

In pre-war years about 80 per cent of Greek figs were packed on strings, 5 per cent were put into fancy packages, and 15 per cent constituted the "refusia", or culls. For the string pack, a long reed or sedge .threaded to a needle is used for the figs, which come from the drying-yard somewhat flattened. Sixty figs are put on a string, the women workers simply piercing each fig or several at a time until the whole number is strung. The two ends of the reed are then tied together to make a complete circlet of figs. Smaller strings weighing about one pound are also prepared. The box shook for packing cases in pre-war years consisted of short lengths of lumber obtained from northern countries. The weight of the cases varied from 55 to 112 pounds net depending upon the market demand.

Production of dried figs in Greece for the 10-year period ending in 1942 averaged 22,900 tons but in 1940 it reached 31,900 tons. In, 1944 the estimated production was only 13,200 tons, the decline probably being due 
more to weather and other factors than to actual war damage. Exports of Greek figs to the United States declined from 6385 tons in 1921 to 295 tons in 1932, while exports to Italy increased from 4232 tons in 1921 to 12,923 in 1930. In 1935 Germany became the best customer for Greek figs and continued so until the beginning of the war.

Algeria:Figs are grown in practically all parts of Algeria except in the high mountains and the dry deserts. Commercial production is most important in the mountainous terrain of the interior near Tizi-Ouzou and Sidi Aich, and on hills a few miles inland from Bougie. Dried figs, stored in stone jars, furnish a substantial part of the food of the native Kabylians. According to Schreiber (1945) :

The production of dried figs in Algeria is a long-established industry and one that is reasonably well organized. The industry has been gradually expanding during the past 25 years. Between 1920 and 1944, production nearly doubled, largely because of French influence. The acreage is about 77 per cent in solid plantings and 23 per cent in scattered plantings. According to French officials, the total number of trees, not segregated as to bearing and nonbearing, was about 8,000,000 in 1942 as compared with the average of 7,200,000 for 1934-1938. It is interesting to note that fully 99 per cent of the trees are owned by natives and only 1 per cent by European settlers.

The 1944 estimate of dried fig production was 20,900 short tons, the largest crop since 1935 when 22,800 tons were produced. Statistics of the port of Bougie show that figs rank second to wine in export tonnage. Normally about 90 per cent of Algerian fig exports go to France. Government-owned disinfecting apparatus exists in Algiers and Bougie, where figs are treated and then sold under the Government brand "Algeria." Fig culture in Algeria has been discussed by Trabut (1904 and 1924), Wheeler (1927), Condit (1924c), M. Widiez (1932), A. Heintz (1936), and N. Mauri (1942).

The average annual rainfall for Algiers is 28.3 inches, for Fort National, at an elevation of 3035 feet, 42.1 inches, and for Bougie, 39 inches. The

\section{Page 88}

\section{Gondit 88 The Fig}

heavy rainfall helps to explain why figs can be grown without irrigation. Orchards located at Tizi-Ouzou in the river bottom consist of trees that are large and vigorous compared to those on the steep slopes of mountains where trees are closely planted and are more or less stunted and scraggly in appearance. Figs are planted on the north slopes, and olives and carobs on the drier western slopes. Orchards in the valleys, with trees spaced 30 to 45 feet apart, are ploughed by oxen, but those on the hillsides with trees 18 to 30 feet apart, are tilled by hand. Very little pruning is done with the 
exception of cleaning out the old wood, and fertilizers are applied only when intercrops are grown. After the figs are harvested, the leaves are often picked from the trees and used for cattle feed.

Fig. 24. Commercial fig districts of Spain and Portugal, proximate areas of greatest importance.)

(Crosses denote ap-

Two important varieties are Tameriout and Taranimt, both white figs. Azendjar is a black fig of good quality both fresh and dried. Caprification is necessary for most of the varieties grown. Figs drop naturally when mature and are dried on reed trays which are exposed to the sun during the day and stacked at night. In the average season, the crop runs about 15 per cent first grade, 45 per cent ordinary, and 40 per cent distillery, or roasting, figs. The general inferiority of Algerian figs is apparently due to careless methods of handling the crop rather than to the varieties grown. Dried figs destined for export are collected by local agents and forwarded to merchants in Algiers and Bougie. The latter city has several packing houses, some of which pack the figs in cartons of one-half or one kilo. Figs

\section{Page 89}

Chapter IX

89

Fig Districts

are also packed in wooden boxes of 10 to 15 kilos and in jute sacks containing about 100 kilos.

Spain:Figs are grown in all the coastal provinces of Spain and in the Balearic Isles. The chief commercial districts are as follows: Huelva, Malaga, Murcia, Fraga, and Majorca (fig. 24). The figs of Huelva are grown back from the coast a few miles, near Cartaya, Lepe, and La Barca and do not rank so high in quality as those of certain other provinces. Packed figs are carted to La Balla, at the estuary of the Rio Piedra, where small sailing vessels pick up cargoes and transport them to various markets. Lepe is the most important center of production and the figs of the province are commonly known as "Lepe" figs. Trees are planted in regular orchard form about 40 feet apart; branches are allowed to droop until they recline on the ground and even take root, a practice which facilitates the picking of fully matured figs for drying.

Figs in Malaga Province are also grown back from the coast a few miles, as at Coin, some being planted in regular orchard form and others interplanted 
with almonds, olives, or grapes. The unirrigated trees are small and often unthrifty but produce fair crops. In the neighboring province of Granada, almond and fig trees are found up to the very tops of mountains 2000 and 2500 feet high. The Turon fig, grown near a village of the same name, receives very favorable mention in market circles of southern Spain and is reported one of the very few Smyrna-type varieties grown in that country.

Spanish records of 1919 indicate that Murcia Province has the largest number of fig trees, the greatest total production, and the highest value of fig products of any province. The trees are in scattered plantings, on borders of irrigated land, and in hill districts rather than in regular plantings. The dried figs are packed at Lorca, Alhama, at Librilla in the interior, and at Aguilas on the coast. A general description of fig culture in the Province of Murcia was given by Escribano y Perez in 1884. The principal varieties for drying are Pajajero, Napolitano, Noral, and Martinenca.

Fraga, an interior town near the border of Huesca Province, is noted for its dried figs. The principal variety, Fraga, is apparently identical with Col de Senora Blanca and Bordissot Blanca grown elsewhere in Spain. Fig trees at Fraga are irrigated or grown on bottom land which is sub-irrigated. This may account for the severe damage which followed the low temperature of November 10, 1921, when fig and olive trees were still in a growing condition. The crop was ruined for several seasons. Late frosts in the spring of 1928 and heavy rains during the ripening period seriously damaged the fig crop of that year. Fraga figs are exported from the port of Barcelona.

Fig orchards on the island of Majorca are located on unirrigated plains and hillsides. A considerable portion of the crop is used for fattening hogs, thousands of which are exported every year from the islands. As many as nine different varieties of figs are commonly planted together in order to provide a long succession of ripening, and interplanting of

\section{Page 90}

Condit

90

The Fig

fig and almond trees is a common practice. Most of the dried figs are packed at Benisalem and hauled to Palma for export.

As a sidelight on the production of figs for hog feed the following anecdote by J an and Cora Gordon (1923) is of interest: 
We went home laden with presents of fruit which Coneni had pressed upon us. Especially was our greed delighted with a large basket of figs. We had been asking the Conenis to bring us figs for some days but they had said: We canl't bring you figs. Nobody sells figs here. We give them to the pigs/ So that evening we rivalled the pigs. *

In various parts of Spain the price of figs and the amount available for export depend considerably upon the barley crop. In 1924, for example, there was a small crop of barley and there was accordingly a keen demand for dried figs, presumably for cattle and hog feed.

Spanish figs were for many years packed in round straw mats each containing 33 pounds. These were known as "Spanish mat figs." Figs are also packed in J4-, 1-, S-, 10-kilo boxes and in various sizes of fancy cartons. The Lepe style of pack consists in flattening out the dried figs and placing them in the boxes, eye end up. In the Fraga style the figs are also flattened but are packed on edge in rows. Such figs are commonly called "fleur" figs. Various packers use different patterns for the top layer, such as circular and diagonal.

Dried figs in the Malaga district are commonly sorted into six grades as follows: Panetes range from 25 to 73 per cent, Verdejos from 10 to 15, Turon 10 to 30, Blancos 4 to 10, Pacuecos 3 to 5, and Black 15 per cent. The best grade, Pacuecos, is relatively unimportant because it comprises such a small quantity of the entire crop. Figs of the Pacuecos and of the Blancos grades are light in color while those of other grades are dark or black. The center of the producing region for Pacuecos figs is the small town of Velez, about nine miles from Malaga.

The Spanish government issues estimates of the fig crop on a fresh fruit basis. The average production for the years 1930 to 1935, exclusive of 1934, was 274,000 short tons, which, if all were dried at a drying ratio of three to one, would amount to 91,000 tons dried. Exports of dried figs for the six-year period ending in 1936 averaged 4485 tons, a very decided decrease from the 15,780 tons exported in 1920. Statistics of Spanish fig production in recent years are unavailable for inclusion in Table 4.

Accounts of fig culture in Spain are given by Estelrich (1910), General Conde de la Algaida (1916), L. J. Dawson (1919), J. M. Priego J aramillo and Santiago Sanchez (1922), Condit (19256), and Wheeler (1927).

Portugal:The commercial production of dried figs in Portugal is largely limited to the district known as Algarve, in the extreme southern part (fig. 24). According to Eisen, Portuguese figs were regarded a century or more ago as the best in the world, or at any rate as the best in western Europe. The superior product of Smyrna, however, gradually superseded that of Portugal both in European and American markets with a resulting decline in the fig industry of Algarve. The two principal 
Chapter IX

91

Fig Districts

ports are Faro and Portimao, both handling large exports of figs as well as chestnuts, almonds, walnuts, cork, and carobs. Some packing concerns at Faro, Alcantarilla, and Portimao make a specialty of dried figs packed in small cartons and in fancy packages for South American trade.

Fig orchards are commonly interplanted with carob trees, vines, or other crops. Most of the orchards are small in size, although some cover 75 acres or more. Varieties are mostly of the Common type. Bobone (1932) describes 27 varieties of Portuguese figs only three of which are of the Smyrna type. The practice of caprification, however, is very prevalent in Algarve, whereas in Huelva Province just across the border in Spain, it is seldom followed.

Portuguese figs become partly dry on the tree and are then shaken off and picked up from the ground. No special methods of drying are used. The harvesting of leaves for cattle feed is extensively practiced.

The common classification of dried figs is: fleur, the largest and best of the crop, demi-fleur, second grade, and comadre, third grade. At Louie a crop will grade about as follows: 5 per cent fleur, 20 per cent demi-fleur, 55 per cent comadre, and 20 per cent culls or distillery stock. At Alcantarilla some of the best crops have a much higher percentage of the fleur and demi-fleur grades. Growers generally sort out the fleur and the cull figs but the packer sorts out the other two grades. Portuguese as well as Spanish figs were once packed in 33-pound mats. These Portuguese mats were known in the trade as "tapnets"; four tapnets were packed together into a "seron" for export.

Dried fig exports from Portugal reached a maximum of 11,895 tons in 1922. Exports to the United States in 1925 totaled 4219 tons, but since 1932 they have averaged less than 100 tons per year. Estimates for 1935 showed 20,639 tons although production figures for other years range from 6000 to 12,000 tons. The estimated production for 1944 was 9400 short tons which was 47 per cent above the 10-year (1933-1942) average. Government regulations were issued in 1933 regarding the grading, classification, and packing of export figs as follows:

Figo flor: extra grade38 figs per 500 grams.

Figo meia flor: choice grade38 to 48 figs per 500 grams. 
Figo comadre: merchantable grademore than 48 figs per 500 grams.

According to Bobone a general account of fig culture in Portugal is given by F. C. Melo Leote (1900). Other accounts are by Eisen (1901), Condit (1925a), and Wheeler (1927).

Other Mediterranean Fig Districts: Fig culture is carried on to some extent in all the larger islands of the Mediterranean Sea and in the countries bordering it. In Morocco, as in many other countries, statistics are available on such fruits as the olive, date, almond, and citrus, but data on the fig crop are included with other tree crops. For example in 1917 the "tertib," or agricultural tax, was paid on 1,461,448 olive trees and on 1,543,129 fig and other trees in the French zone of Morocco.

According to Foreign Commerce Weekly for October 24, 1942, there

\section{Page 92}

\section{Gondit}

92

The Fig

are about 5,000,000 fig trees in Morocco. The government has stimulated interest in fig culture by establishing two demonstration drying centers. Practically the entire crop is consumed in Morocco.

R. W. Hodgson (1931) found numerous varieties of figs both of the Common and of the Smyrna type growing in Tunis. The plantings are small and often consist of fig and olive trees interset. Statistics of 1929 show 900,000 fig trees as compared with $16,500,000$ olive trees and 2,650,000 date palms. The principal production centers are Sfax, Djerba, Zarzis, and Cap-bon, but there are small plantings in all native communities. The quality of the dried product is inferior and generally not suitable for export.

Fig trees are very common in all oases along the Libyan coast; on the Gharian mountains, some 50 miles inland, the culture of figs is of considerable importance up to 1000 feet elevation.

Figs have been grown in Egypt since ancient times, but their culture has never been given much attention. According to $\mathrm{M}$. Badie and Ahmed Ghamrawy (1931), there were in Egypt in 1925 about 2900 acres of fig trees. This acreage is declining for various reasons such as close planting, insect pests, and poor methods of culture. Varieties grown are almost all of the Common type and most of the fruit is consumed fresh. Sultani, or Faiyoumi, 
the most common variety, bears two crops of purplish-brown figs with strawberry-colored pulp. There is a greenish-yellow fig called Assuani and a purple one named Abboudi.

Fig culture in Palestine is mostly in the hands of Arabs, only small plantings having been made by J ewish colonists. According to Asaph Grasovsky and J oseph Waitz (1932), the fig tree is so common in some districts that its name has been given in some form to localities, such as Beit-Fajjar near Bethlehem and Ain-Tin near SafTuriya. In Ramleh, Ramallah, and Gaza the trees are planted in orchard form, but near J erusalem and J affa they are found mostly as scattered trees. About 80 per cent of the plantings are in the hill and mountain districts. Of the 36 varieties grown, 15 are common both to southern and northern Palestine. The variety Khar-roubi is the most popular black fig; Khdari and Biadi are standard light colored figs.

In Syria, fig culture is extensively carried on in coastal districts. Trees are found from the sea coast up to 3900 feet elevation in Lebanon with the rainfall ranging from 18 to 35 inches annually. There are no fewer than 10 to 15 varieties grown, the Buchrati for fresh fruit and the Bayadi for drying being the most common.

In France, figs are grown from Paris south to the Mediterranean. Argenteuil near Paris has long been noted for its production of fresh figs. Since the climate is not suitable for fig culture as ordinarily practiced, special methods described in a later chapter have been developed by which excellent figs of the Blanquette variety are produced in quantity. The Dauphine, a violetcolored fig, is grown near Frette for fresh fruit of the breba crop. Good accounts of this specialized fig culture have been given by Alphonse du Breuil (1876), by Eisen (1901), and by Edmond J uignet (1909). Literature on fig varieties and the growing of figs in

\section{Page 93}

Chapter IX

93

Fig Districts

other parts of France is voluminous. Two accounts are by du Breuil and by $E$. de Mazieres (1920).

While some figs are dried in southern France, the trees are grown mostly for production of fresh figs, which in normal seasons are shipped to northern French cities and even to London. Eisen lists 19 varieties of white, 16 varieties of brownish, and 6 varieties of black figs. The Violette, grown near 
Toulon, is a purplish fig which has a good appearance and carries well to market but lacks quality. In packing the fig, the stem end is passed through a circular disc of green paper and then embedded in excelsior in a box containing from 12 to 24 fruits. The Petite Marseillaise is a small fig grown in the hills for preserving purposes. It is also dried.

A good account of fig culture in Cyprus has been given by P. M. Symeonides (1930). Trees are common from the sea coast to 5000 feet elevation. About fifty years ago fig prices were so low that many trees were uprooted and the acreage greatly reduced. In May, 1897, a fig tax in the form of a subsidy stimulated interest in the fruit and its culture. The varieties grown do not require caprification. The village Aglasika, from aglaos, "excellent," and sika, "fig," is noted for its good figs. Another village, Makrasyka, from makros, "long," and sika, "fig," grows a variety with thin skin and small seeds.

Fig trees both of the Common and of the Smyrna type are grown on the island of Malta. The figs, dried in the oven and eaten with barley bread, furnish one of the main foods of the peasants. J. Borg (1922) described some thirty varieties of figs grown on the Maltese Islands.

\section{Page 94}

\section{Chapter X}

\section{OTHER FIG DISTRICTS}

Commercial fig districts of the Old World and districts of minor importance bordering the Mediterranean Sea have been considered in the previous chapter. Fig growing in other parts of the world will now be discussed.

Russia: Parts of southern Russia bordering on the Black and Caspian Seas are well adapted to the culture of subtropical fruit trees including the fig. At Yalta, in the Crimea, the Government Botanical Garden has long been conducting experiments on various phases of fig culture such as variety studies, breeding, hardiness of trees, pruning, chemistry, and botany. A collection of 50 varieties planted in 1925 was increased by 1938 to more than 200 obtained from other countries. Results of the work on figs are outlined in a publication by Miss N. K. Arendt in 1939.

Asia:In Asia, figs are cultivated to some extent in Arabia, Persia, India, China, and J apan. Early reports show that fig trees thrive and produce abundantly throughout the entire peninsula of Arabia, but little, if any, information is available on present-day culture.

In Persia, figs are grown in every province except in the colder regions of the northwest. The annual production is estimated at 3267 short tons. About one 
third of the crop is dried, the rest being consumed fresh. Russia, India, and I raq are the leading markets. Importers have long urged the Persian producers to take more care in preparing and packing dried figs but with little success.

The following extracts are taken from a personal letter received from Walter Koelz, United States Department of Agriculture Plant Explorer, May, 1938:

In Afghanistan they have some remarkable fig trees. Those grown in the Mamakhel district are well known and are said to be of superior quality. The only first-class fruit I saw in the fresh state was from the north along the Siberian border. Tashkusghan figs are famous. They grow usually as shrubs or small trees in clumps, branching from the root. The fruits run about 1.5 inches in diameter, are reddish purple and of fine quality. In the south where there is a semi-desert, I found good dry figs, white and black, produced on rather good-sized trees. There is virtually no precipitation in the fig-growing districts from May to December.

Figs do not thrive in the tropical regions of southern Asia. European varieties are grown in the drier upland zones of Ceylon, but monsoon rains interfere with proper maturity of the fruit. According to G. M. Woodrow (1910), in some parts of India individual figs as they ripen are protected from pests by a pair of small baskets held face to face by skewers and string. Perforated tin boxes are also used. Commercial production of figs is limited to one section near Poona where 1200 acres are planted.

\section{Page 95}

\section{Chapter X}

95

Fig Districts

The one variety grown, the Poona fig, is of medium size, bell-shaped, of a light purple color, and has a strawberry pulp. The elevation is about 2500 feet; at lower elevations fig-leaf rust is serious on account of the higher humidity. Dormancy of trees in August is induced by heavy rains which begin in May and last into October. The trees bud out in October and produce a crop which ripens in March and April. A large percentage of the crop is prevented from maturing by the monsoon rains which, over a 43-year period, have averaged 22 inches annually. Since markets for the fresh figs are limited, experiments in methods of drying have been carried on. During April and May the fresh figs, carefully picked from the tree and then exposed to sulphur fumes, are sun-dried on trays in from 5 to 7 days. An account of fig culture at Poona is given by S. R. Gandhi (1924). 
In China small fig plantings are occasionally found as far north as Shanghai and Nanking. The Brunswick variety is being grown in a small way at both places and the fruit matures during August. Small plantings of a greenishyellow fig are found between Hangchow and Ningpo. Fig trees are very susceptible to the attacks of coleopterous borers in central and south China. In north China, various flowering and fruiting trees, including the fig, are grown in pots or tubs with winter protection.

Small plantings of figs are found in Japan on the Island of Honshu. The humid climate does not permit drying of the fruit, but the fresh figs find a ready market. San Piero, known locally as Masui Dauphine, is the leading variety, although several others have been introduced. Brunswick was once grown but has lost favor on account of its susceptibility to fruit spoilage. Dauphine has only one crop but the figs are of good quality. At Kawasaki between Tokyo and Yokohama there is a Fig Association of 250 growers. The average orchard is about one acre in extent. Fifty per cent of the trees are Masui Dauphine, 30 per cent true Dauphine, and 20 per cent other varieties. The Imperial Horticultural Experiment Station at Okitsu has conducted investigations on figs for several decades and a few promising seedlings have been developed by breeding.

Africa: In the temperate zones of central and south Africa, European varieties of figs are commonly grown. Dried fruit statistics for the Union of South Africa show that the production of raisins, sultanas, currants, apricots, peaches, and prunes each exceeds that of dried figs, which amounts to only 150 short tons. In 1930 there were 341,590 commercial fig trees in the Union as compared with 466,130 trees in 1926, a considerable reduction. Most of the production came from the Tulbach, the Ceres, and the Montagu districts. The 1930 census indicated that 36 per cent of the acreage in the Tulbach area was non-bearing. According to R. A. Davis (1928), there were then 300,000 fig trees, bearing and non-bearing, in Cape Province and about half that number in the Transvaal. The Free State had over 200,000 trees and Natal about 40,000. The best fig areas are in parts of the Karroo where the trees attain large

\section{Page 96}

Condit

96

The Fig

size and the climate favors drying of the fruit. Neither the Transvaal nor Natal produces dried figs on a commercial scale. 
Davis lists and describes such common varieties as Adriatic, good for eating fresh and for drying; Brunswick, a fine dessert fig which will grow almost anywhere in the Union; Cape White, good for jam; Castle Kennedy, a good dessert fig; Negro Largo, one of the best figs grown and suitable for fresh fruit only; Osborn Prolific, a good dessert fruit; Panache, or Tiger, a hardy tree found all over the Union; and White Genoa, excellent both for eating fresh and for drying. The Lob I njir and several varieties of caprifigs were introduced from California and the blastophaga was successfully colonized in 1908. Since the season is the reverse of that in the northern hemisphere, the crops of the caprifig tree mature as follows: profichi, September to J anuary; mammoni, J anuary to March; mamme, March to September. Culture of Smyrna-type figs has not attracted much interest and the acreage planted to such figs is therefore small.

Australia: The fig industry is of minor importance in Australia, the total acreage of bearing and non-bearing trees in 1944 being only 931 acres. The production, calculated in bushels of 32 pounds avoirdupois each, amounted to 71,683 bushels of fresh fruit. \{See Fruit World Annual, Melbourne, p. 24, 1945.) At least 90 per cent of the fresh figs in Queensland are made into jam, the rest going to the fresh fruit market. The average amount delivered to the jam factories of Queensland during the four-year period ending in 1944 was 110 tons at a delivered price of about twopence per pound. The Fruit Growers Organization instituted a ^ $\mathrm{g}$ levy of 5 shillings a ton on fresh figs beginning in 1941, the amount to be used mainly in advertising the factory production of jam. Owing to the war the proposed advertising has not been carried on, but the levies are accumulating for future use.

In New South Wales one company alone handles 200 tons of figs for jam and the estimate for all Australia is $\mathbf{5 0 0}$ tons per year. The principal varieties grown are Cape White, the best for making jam, Brown Turkey, White Genoa, and White Adriatic. The last named is not popular because its internal color is strawberry, especially so when the figs are caprified; in one district all the caprifig trees were removed for this reason. In 1925 C. G. Savage published an account of "Smyrna fig culture in Australia/ $\backslash$ ' but the area now planted to this type of fig is probably very small. The bulk of dried figs is produced on the Murray River irrigation area of South Australia. According to Charles Stmmons, Smyrna-type figs were being produced in 1924 in Western Australia, where the Roeding varieties as well as Robsonl's Special and Simmons caprifigs were being grown. Figs are not extensively grown in New Zealand.

Great Britain:Fig trees are common in Great Britain both as pot plants in forcing houses and as standard trees out-of-doors. They are more often planted along walls with a southern exposure. As far back as 1568 William Turner wrote, "the figge tree is so well knowen that it nedith no farther description." Since that time literature on fig culture in 


\section{Chapter X 97 Fig Districts}

Great Britain has become voluminous but is mostly found as chapters in books or articles in horticultural publications.

In 1904 Owen Thomas described the fig gardens near Worthing and Sompting where are produced most of the home-grown figs found in the Covent Garden market. The trees then averaged about 80 years old and some were over 100 years old. They were given very little pruning and practically no manure, yet rarely failed to produce a satisfactory crop of figs. The one crop was harvested between the second week in August and the middle of October. The famous gardens at Tarring, near Worthing, consisted of about 150 trees, and 24,000 excellent fruits were produced annually. White Marseilles was the most valued and luscious variety, but Brown Turkey was also grown. John Wright, however, stated in 1894 that the figs grown at Tarring were chiefly Brown Turkey. The large White Marseilles tree was believed to be a descendant of one of those planted by Thqmas a Becket. In fact in 1894 a picture post card was still available showing a fig stump with this inscription: "The remains of old fig tree planted by Thomas a Becket about A. D. 1162."

Reference is made in chapter VIII to the Chiswick collection of fig varieties. For many years this was maintained in a special glass house at Chiswick by the Royal Horticultural Society, and in 1901 it was considered to be the best collection of figs in the world. Descriptions of varieties by A. F. Barron and others were based to a considerable extent upon specimens grown at Chiswick. Cuttings of the entire collection of 66 varieties were brought to the United States in 1894. The varieties most commonly grown in England are Brown Turkey, Brunswick, Negro Largo, and White Marseilles. For growing under glass, Bunyard (1934) strongly recommends Negro Largo, which is probably the same as San Piero of Italy. White Marseilles thrives indoors as well as outside on walls. White Ischia, Black Ischia, and Bourjassotte Grise are suggested as varieties for the epicure.

\section{FIG DISTRICTS OF THE NEW WORLD}

In the Western Hemisphere figs are grown commercially in California, Texas, Argentina, Chile, and to a lesser extent in some other states and countries. Even on Vancouver Island in British Columbia some varieties of figs produce good fruit.

Central and South America: Culture of the fig tree in Mexico was described by M. Calvino in 1912. In Lower California there are regular orchards of a black fig, probably the Mission, grown at Mulege and at San Ignacio. The fruit is sun-dried and consumed locally. According to P. C. Standley (1920), the fig is extensively cultivated in Mexico for its fruit, which under favorable 
circumstances is produced at all times of the year. In the countries of Central America, fig trees thrive best in the temperate climate of mountain districts such as Guanacaste Province of Costa Rica.

According to G. M. McBride (1936), the valleys of northern Chile have almost continuous sunshine and produce dried figs, peaches, and other fruits of excellent quality. In small plantings, rows of old fig trees

\section{Page 98}

Condit

98

The Fig

alternate with peach and pear trees. In central Chile almost every house has its own vines and fig trees planted nearby. A black fig similar to, if not identical with, the Mission is the leading variety.

Following a recent trip to Chile, Walter Ebeling reported:

There are probably about 100,000 fig trees in Coquimbo Province alone, and from 20,000 to 30,000 trees in the neighboring Atacama Province. The streams that run through the narrow canyons from the Andes to the sea, are lined with fig trees growing singly or in groups and occasionally in irregularly planted groves. One may follow these streams back toward the high mountains for 50 miles and not once be out of sight of fig trees. (Unpublished report by W. Ebeling, 1945.)

Argentina had, in 1937, a total of 292,000 fig trees and a production of 2100 tons of dried fruit. Both white and black figs are grown, and they are dried either in the sun or in dehydrators. F. M. Croce (1937) discusses methods of drying, washing, and packing figs in Argentina.

In the West Indies, fig trees are found on many of the islands but only in small numbers. Experimental plantings at St. Croix in the Virgin Islands were made several years ago; the trees were found to be fairly well adapted to climatic conditions but very susceptible to attacks of borers and to infestation of the pustule scale. As early as 1623 figs were sufficiently abundant in Bermuda to be dried for food, and several varieties are still cultivated at St. George.

Fig culture in the United States will be discussed under the following headings: Northern United States, Southern United States, Texas and certain Western states, and California. 
Northern United States:Fig culture in the United States north of the Mason and Dixon line has long been practiced. There is a report that in $1845 \mathrm{Dr}$. Dwight, formerly President of Yale College, successfully cultivated figs in the open ground. In 1869 J ames T. Worthington published a Manual \{of Fig Culture in the Northern and Middle Stated of ten pages, and later Martin Benson (1886) got out a similar pamphlet of eight pages. John W. Chamberlain (1919), after considerable experimentation, regarded the fig tree as a very satisfactory fruit plant for the north. In the fall of $1931 \mathrm{~S}$. N. F. Sanford (1933) found a fig shrub not only growing on the sunny side of an old building in Massachusetts but even bearing some fruit. In New York, Philadelphia, and other cities, there are literally hundreds of fig trees grown either in pots or in sheltered places where they can be given winter protection. Trees are especially numerous around Flushing, Long Island, and Newport, Rhode Island. Methods of protecting fig trees from winter cold will be discussed in a later chapter. Edwin Beckett (1941) gives a brief account of fig culture in the vicinity of New York City and illustrates a fruit of Brown Turkey as the outstanding variety. Many other varieties such as Brunswick, Green and White Ischia, and Negro Largo are grown.

Southern United States: From the District of Columbia south to Florida and west to Texas, the fig is planted about buildings probably more commonly than any other fruit tree. The fact that it grows better near buildings is probably due to protection from winter injury, to less serious

\section{Page 99}

\section{Chapter X}

99

Fig Districts

infestation of root-knot nematodes, and to less frequent injury to feeding roots by cultivators. The plants are commonly designated as "fig bushes" on account of the shrub-like habit of growth resulting from occasional frost injury to the tops. Small commercial plantings are found in Maryland, Virginia, Georgia, and Florida for the production of fresh figs for market or for preserving. The two varieties most widely planted are Celeste and Brown Turkey, although Brunswick, Marseilles, or Lemon, and a few other varieties, are also found. A few concerns in Louisiana put up preserved figs in tin and in glass containers, along with other products. One company has handled 38 tons of Celeste figs in a single season, the fruit all coming from dooryard trees. Another packs 1500 cases annually in ten-ounce tins.

Various Experiment Stations in the South have, in the past, carried on work with the fig and its culture; but most of such experimental work has been 
restricted or discontinued in favor of more important and more profitable fruits. The result is that much of the fig literature is several decades old. However, the following may be cited: for Georgia, H. N. Starnes (1903), Starnes and Monroe (1907), and B. W. Hunt (1914) ; for North Carolina, F. C. Reimer (1910); for Florida, H. S. Elliot (1915) ; and for the South in general, F. S. Earle (1897) and H. P. Gould (1935).

Texas and Certain Western States: In Texas, as in California, increase in fig acreage and production has been largely due to the activities of promoters. In many instances they planted large tracts and sold them to growers who expected quick profits. Stansel and Wyche (1932) thus summarize the early fig situation in Texas:

The first commercial production of Magnolia figs in Texas occurred between 1901 and 1903 near Algoa, Galveston County. The first commercial figpreserving plant was built at Aldine; . . . this plant was later moved to Friendswood where the industry was first firmly established. At this time the method of scalding figs to remove the skin before preserving was kept a secret. By 1913 over-production gave the industry a serious setback. In 1915 or 1916 the deriiand for preserved figs was again greater than the supply and by 1920 producers were receiving 4 to 7 cents per pound for their figs. These prices stimulated production until in 1925 and 1926 the industry-was again facing serious over-production. In 1928 there were 16,000 acres in bearing orchards, and while only $14,000,000$ pounds of figs were packed, it was estimated that $20,000,000$ to $25,000,000$ pounds of fresh fruit were produced. Since 1928 the acreage has decreased until in 1931 the total productive area was not over 5,000 acres.

The variety of fig grown commercially in Texas is Brunswick, known locally as Magnolia. Celeste is also grown in small plantings. Brunswick is pre-eminently successful in the vicinity of Houston where the mean annual rainfall is 40 inches and the mean relative humidity is 80 per cent. The trees begin to bear during the third season in the orchard unless winter injury has set them back. Yields gradually increase from year to year to a maximum of 6000 pounds per acre. The season of ripening extends from the middle of J uly until cool weather in October.

The Texas crop is handled by six concerns, the largest two being located at Alvin and Friendswood. Between 80 and 90 per cent of the figs are

\section{Page 100}

Condit 
The Fig

packed in glass in a syrup of about 240 Baume. In the twenty-year period ending in 1942 the average fig pack of Texas was 2040 tons; the smallest pack was 510 tons in 1932 and the largest, 6510 tons in 1928.

SanFrancisci

Stockton $+* \backslash 1$

II

II

II

II

Rivers/ate + 0J ndio

Sandlego

Fig. 25. The commercial fig districts of California are located mainly in the San J oaquin Valley from Visalia north to Stockton. (Crosses denote approximate areas of greatest importance.)

Fig investigations, conducted mostly at Substation No. 1 near Angleton, have been made of varieties, breeding, pruning, methods of utilization, and other cultural matters. Accounts of fig culture in Texas have been pub-

\section{Page 101}

Chapter X

101

Fig Districts

lished by Potts (1917), Stansel and Wyche (1932), and Condit (1941a).

Figs are grown to some extent in Arizona, Utah, Oregon, Washington, and in the Territory of Hawaii. Arizona, like Texas, and California, has been the victim of unscrupulous promoters of fig plantings. In 1928 and 1929 a few hundred acres of Kadota figs were promoted by four different companies near Casa Grande, but the acreage later failed to produce the expected 
financial returns. Attempts to grow the fig commercially on the Yuma Mesa have been largely nullified by the ravages of the root-knot nematode. While there are no commercial fig plantings in Arizona, the trees thrive and produce good fruit in many localities in spite of summer showers. Exceptionally large trees, mostly of the Mission variety, are seen as isolated specimens near Kingman and in the foothills of the Dragoon, Santa Catalina, and Santa Rita Mountains. In 1916 W. H. Lawrence published a bulletin entitled, Practical Fig Culture in Arizona.

On account of its mild climate, Washington County in southern Utah is sometimes referred to as Utahl's Dixie. Fig trees were found growing there as early as 1866 and some commercial plantings have since been made. In 1927 about 20,000 Magnolia fig trees were shipped in from Texas and planted. By 1930 not more than 6000 trees were alive, and these were not producing so well as expected. One of the most enthusiastic and successful growers is Amos Workman, Hurricane. For periods of as many as twenty years fig trees on his place have gone through the winters without serious injury; then a temperature of zero or lower, such as that which occurred in 1936-1937, has killed even 18-inch trunks back to the ground. The varieties grown are Mission, Kadota, and Marseilles. There are also numerous fig trees around Toquerville. One fig bush is found even near the entrance to Zion National Park where the elevation is 3800 feet and where the 1938 temperature fell almost to zero.

In Oregon, fig trees have long been grown at Ashland, Medford, Portland, and other places, where some small commercial plantings produce fresh figs for local markets. Numerous varieties have been tested and distributed by $\mathrm{B}$. R. Amend, Portland. Fig trees are also commonly found in the vicinity of Seattle, Washington. Trees which are protected from damage by spring frosts set a crop which matures in August. The second crop develops slowly on account of cool weather and is often seriously injured by September rains or fall frosts. Varieties which set and mature a good first crop are well worth growing in sheltered places.

The fig is of minor importance in Hawaii. However, market reports show that light to moderate supplies of local fresh figs are on sale in Honolulu every month in the year. On May 22, 1944, W. B. Storey, University of Hawaii, wrote: "Our own Brown Turkey trees have been producing figs for fully two months now, while our Kadota trees in the same locality have just matured their first fruits within the past two weeks." There are small plantings of figs on the island of Hawaii, but damage to the fresh fruit by myna birds and doves is severe. The Lob Injir fig and the bias-

\section{Page 102}

Condit 
102

The Fig

tophaga were successfully established at one time, but both have apparently disappeared.

California:The state of California (fig. 25) has become the third or fourth most important fig-producing district of the world. In 1943 there were in the state 33,812 acres of bearing fig trees and 687 acres of non-bearing. The bearing fig acreage of the principal counties is as follows: Fresno, 17,101; Merced, 8631; Tulare, 2619; Madera, 1236; Yolo, 1137 acres. The 1943 crop of dried figs was the largest on record, amounting to 29,900 tons of merchantable grades and 6800 tons of sub-standard fruit. The bearing acreage according to varieties shows Lob Injir leading with 13,303 acres, followed by Adriatic with 8923, black varieties with 5903, and Dottato with 5130 acres. However, Adriatic, with its smaller acreage, exceeds Lob Injir in tonnage of dried figs. The effect of fig promotion schemes upon fig acreage is shown by the fact that although in the San J acinto Basin of Riverside County 5680 acres were reported in 1930, only 3 acres were listed in 1938 and these have since passed out of production.

Adriatic, Lob I njir, and Mission figs for drying and Dottato figs for canning are produced in the San J oaquin and the Sacramento Valleys of California. San Piero is grown in Los Angeles and Riverside Counties for the local fresh fruit market. These varieties, as well as several others of the Common type, are planted in dooryards throughout most of the state. As the result of experimental work on varieties and culture carried on at the University of California Citrus Experiment Station at Riverside and elsewhere, a circular by Condit, Fig Culture in California, was published in 1933 and revised in 1941. Methods of handling and marketing the California fig crop are discussed in other chapters.

\section{Page 103}

\section{Chapter XI}

\section{CLIMATOLOGY}

The fig tree is a deciduous subtropical, a native of arid, semi-desert regions where its successful culture is limited more by the low temperatures of winter than by the high heat of summer. The fruit is more subject to the vagaries of climate than almost any other cultivated fruit. Reference has already been made to the reduction of European fig crops by winter cold and by summer showers. A survey of crop reports made by California statisticians reveals statements such as the following: "The fig crop suffered quite severely from 
the heavy April frosts;" "Adverse weather conditions during the latter part of September and early part of October reduced production below that of 1922;" "Adverse conditions attributed to the drought, reduced the production of dried figs to 1000 tons below the 1923 crop." There was some loss in the merchantable tonnage of Lob Injir (Calimyrna) figs because of unfavorable weather for maturing the 1941 crop. Weather conditions which affect the fig tree or its production are: frost, heat, rainfall, wind, humidity.

Frost:Young fig trees are very susceptible to frost injury. In widely separated regions of California, trees from one to three or four years of age have occasionally been frozen to the ground; hundreds of acres have thus been ruined or given a serious set back. Experience shows there are three seasons when serious frost damage may occur: the fall season, during October and November while the foliage is still green, the winter period, when the trees are dormant, and early spring, when the tree is starting its vegetative growth. The most serious, but fortunately the most infrequent damage is done by spring frosts, young fig trees sometimes being thus killed root and all, owing to secondary development of sour sap. Both brebas and profichi are sometimes seriously injured or even completely destroyed by a drop of 3$40 \mathrm{~F}$. below freezing in early April. The variety factor has some bearing upon the extent of the damage by spring frosts. Adriatic, which starts to leaf out a week or ten days before Lob Injir, may be seriously injured and the latter may escape injury. Trees of Ficus palmata show unusually early vegetative growth and are therefore very susceptible to spring frost injury. Varieties such as Dottato (Kadota), trees of which are pruned back to short stubs each winter, are relatively safe from such injury. Light fall frosts may cause leaves to drop and induce early dormancy. A heavy frost generally kills leaves and immature branches. Moderate frosts may kill the leaves and buds of young trees, but the wood dies back gradually to uninjured buds lower down on the stem.

The amount of cold which dormant fig trees will withstand depends upon such factors as variety, degree of dormancy, and condition of the

\section{Page 104}

Condit

104

The Fig

trees. One reason why Celeste and Eastern Brown Turkey are so extensively planted in southeastern United States is that the trees become dormant early and withstand lower temperatures than do most other varieties. In California the Mission is apparently more tender than other commercial varieties. Mamme figs of Roeding No. 3 are more susceptible to frost injury than are 
those of Stanford or Milco. In a fig-variety test made by the California Station at Tulare in 1891, it was found that 2 or 3 kinds could probably not stand the climate, 10 varieties showed appreciable loss of wood, and some 36 others suffered only slight damage. A grower in Maryland reports that Lemon fig trees freeze to the ground at 150 and do not produce fruit on sucker growth the first season. On the other hand, Brunswick (Magnolia), Early Violet, Green Ischia, San Piero, and Eastern Brown Turkey do set and mature fruit on sucker wood if weather conditions are favorable.

Chandler et al. (1937) regard the fig and the persimmon as examples of deciduous trees that have a slight chilling requirement. These usually remain dormant during mild winter weather but in some climates such as south Florida, they show a tendency for uneven starting of buds. This probably accounts for the fact that fig trees are sometimes more severely injured by cold weather in the lower South than in districts, such as North Carolina and Maryland, where they remain dormant until spring. Stansel (1933) reported that most fig trees in the Angleton section of Texas were killed to the ground by a February freeze but that Magnolia figs in the Experiment Station orchard escaped severe injury. This was largely attributed to proper care of the orchard, which resulted in stronger and more vigorous tree growth than in neglected orchards. Trees unpruned or moderately pruned have never been injured so severely in Texas as trees heavily pruned the previous season, an indication of the greater susceptibility of sucker growth to cold. Furthermore, trees on which leaf rust was not controlled by spraying suffered severe winter injury when the temperature reached $160 \mathrm{~F}$., but trees properly sprayed were uninjured.

It is impossible to set a definite temperature below which dormant fig trees will suffer injury since conditions of the plant and of climate vary from year to year. At Beeville, Texas, trees were uninjured when the temperature dropped to $130 \mathrm{~F}$., on J anuary 2, 1911, and to 110 a year later. According to Hodgson (1934), a drop in temperature to 150 or $180 \mathrm{~F}$. in California resulted in some injury to the fruit buds. At 100 to 120 and lower, healthy mature trees were not much injured, but severe injury did occur to old trees and to young bearing trees. Injury was very severe at 60 .

Notes taken by H. R. Fulton at Washington, D. C, and vicinity show that most fig trees suffered no injury in the winter of 1941-42 with an official minimum of $60 \mathrm{~F}$. The following winter with temperatures down to 40, most of the seven- or eight-year-old trees were killed back to the framework branches. At Cambridge, Maryland, trees of Celeste, Brown Turkey, and Early Violet were not injured by a temperature of about $30 \mathrm{~F}$., but at the same temperature some Brunswick fig trees showed injury to one-year-old wood. According to a letter from Director Or- 
Chapter XI

105

Climatology

land $\mathrm{E}$. White, winter temperatures reach from 60 to $180 \mathrm{~F}$. below zero at the Blandy Experimental Farm, Boyce, Virginia. Trees of Ramsey and Brunswick varieties freeze back to the ground, but the following season suckers grow from 4 to 5 feet in height; with only slight protection from winds, they bear a satisfactory crop of figs in October. In 1911, Texas fig trees were not injured by the low temperature of J anuary 1; but mild weather later in the month and in early February caused them to start growth, and they were seriously injured later by a light frost.

According to V. Viatkin (1936), one-year-old dormant fig branches are able to resist injury by brief periods of cold as low as $140 \mathrm{~F}$. Comparative resistance of varieties may be artificially tested by exposing branches of the same degree of dormancy to various low temperatures. Differences in soil-moisture content do not affect resistance of fig trees to cold weather.

Methods of Protection from Frost: Orchard heaters are not used for protection of fig trees, but their use can prevent damage to fruit. It has been found that 70 heaters of the lard-pail type per acre will raise the temperature $70 \mathrm{~F}$. in 15 minutes and will usually save first-crop figs from injury. Caprifig trees planted in groups can be heated and both mamme and profichi crops can thus be protected from frost injury.

Fig trees grown in cold climates can be and commonly are protected from winter injury, often by elaborate structures. In north China, where temperatures sometimes drop to 150 below zero, gardeners protect fig trees with a plaster of mud and straw. In Algeria, twigs are commonly covered with a layer of cow dung to protect them from cold. Late immature fig branches are protected in southern Italy by enclosing them in hollowed-out Agave leaves or in cloth. According to Edwin Betts (1944), a record left by Thomas J efferson May 12, 1798, showed that fig trees from which winter covering had been removed were blasted by a frost and injured beyond recovery for that year; fig trees with a winter protection of straw, began ripening their fruit in July, but figs on trees without protection (presumably of the second crop) did not ripen until September.

There are two general methods of growing fig trees in north-central United States. The first method is to plant the tree in a pot or tub which can be moved to a cool cellar for the winter season. By the second method trees are grown in sheltered places near buildings and given various sorts of winter protection. The following directions give one good method of protection: about November 15 prune off superfluous branches, wrap each remaining branch in several layers of paper, tie together and wrap entire bundle, first 
with old blankets and then with oil cloth or tar paper, place a conical cover over the top to shed rain, uncover about April 15.

In more southern districts other methods of winter protection are used. F. C. Reimer (1910) found that up to five years of age fig trees could best be protected by growing them in an inclined position and then bending them to the ground and covering them with dirt in November. If trees are older, the branches are tied together, bent downwards, and the whole covered with any available material, such as pine boughs, straw,

\section{Page 106}

\section{Condit 106 The Fig}

or excelsior. At Argenteuil, France, fig trees are trained to produce low branches, each of which can be bent down in November and covered with soil until spring. Leaves and green figs are all removed a couple of weeks before the time of covering. Accounts of this method of protection are given by E. J uignet (1909) for France and by Massey (1903) for North Carolina. Young trees in Texas and California are commonly wrapped in corn stalks for the first winter or two. The stalks should be tied firmly in a bundle four or five inches thick around the trunk with the butts resting on or slightly buried in the ground. A mound of dirt around the trunk will protect it from damage even though the top freezes back.

Heat:The marked effects of climate upon variety characters have already been mentioned. The Bardajik is grown in coastal districts near Smyrna where, according to Hagan, it develops into the largest and most succulent of figs. On the other hand, it produces small figs when grown a short distance inland or where it is exposed to warm land breezes at night. Similar differences are noted in California between Adriatic and Osborn figs grown along the coast and those grown in hot interior valleys. Hagan gives the day temperature of the Meander Valley in J une from 850 to $950 \mathrm{~F}$., and the night temperatures from 600 to 700 . During the last three weeks in July and the first week in August the maximum daily temperatures range from 980 to 1080, with night temperatures dropping from 15 to 250 below the maximum. These temperatures are comparable to those in fig districts near Fresno, California.

Vital temperature, that which must be reached before vegetative growth begins, is not definitely known for fig trees. For citrus trees it is $550 \mathrm{~F}$. Michel Adanson (1763) reported that fig trees near Paris leafed out about April 20 after 760 units of heat had accumulated (presumably days $X$ degrees above zero0 C). The first crop of figs matured August 3 with an average of 2650 units, and the late crop matured October 8 with 3625 units of heat. In California there are sufficient heat units, even in the vicinity of San Francisco Bay, to mature two crops of some varieties for fresh fruit consumption. A 
higher summation of heat units is necessary to produce figs for canning or drying. Day temperatures of 95 to $1000 \mathrm{~F}$. favor drying of figs. Temperatures much above 1000 ripen figs prematurely, cause the skin to become tough, and increase the proportion of figs deficient in pulp, commonly known as "floaters." Figs dry well at Fresno and Merced. At Stockton cooler days and nights delay maturity of the fruit, and the higher humidity interferes somewhat with drying. Some figs would dry well at Riverside if spoilage diseases were not so prevalent and if trays were stacked on foggy nights and mornings. Warm days and nights coupled with high humidity at Angle-ton, Texas, bring figs to maturity but usually prevent sun-drying.

The effect of extremely high temperatures, such as those experienced in the California deserts, is to hasten maturity of the crops and to lengthen the season, as mentioned in Chapter IV. High temperatures seem to be fatal to blastophagas for they often fail to colonize successive mammoni crops in desert regions. Vegetative growth is favored by heat and sunshine.

\section{Page 107}

\section{Chapter XI}

107

Climatology

Both young and mature fig trees, therefore, show a remarkably vigorous growth in desert plantingsunless the roots are attacked by nematodes or other pests.

Rainfall: The effects of drought upon the comparative growth of fig and olive trees is illustrated by an abandoned six-acre orchard near Palm Springs, California. It was planted to olives interset with figs in 1891. Twenty years later S. C. Mason commented on its appearance as follows: "the contrast between the green of the olives on either side and the figs, which are dead save a few struggling sprouts, illustrates in a most marked way the comparative drought resistance of the two." Isolated fig trees are common in the foothills of California, but their size and vigor depend upon the soil moisture available. Deficiencies in rainfall must be overcome by supplies of irrigation water for successful production of either fresh or dried figs.

Summers which are rainless, or nearly so, provide the best condition for the drying of figs. Rainfall in the Meander Valley ranges from 21 to 29 inches annually but comes mostly from October to May. In other European fig districts there is enough rainfall generally to make irrigation unnecessary. At Fresno, California, the average rainfall of 10 inches makes one or more irrigations a year necessary for most orchards. 
Fresh figs are being successfully grown in regions of summer rainfall and high humidity in most of southern United States. Prolonged showers, however, prevent harvesting and favor fruit spoilage. The prevalence of summer rains in Arizona affects the quality of figs and interferes with drying. The Hunt was selected from other seedling figs because its long stalk, which bends downward, has a tendency to shed water away from the eye.

Humidity and Wind:Humidity figures for Merced and Stockton are not available, but humidity at Fresno during August normally ranges from 17 to 24 per cent at 4:30 p.m. A decided increase in percentage of humidity, generally coupled with lowered temperatures, is likely to increase loss of figs from splitting. In contrast to Fresno, humidity at Riverside in August ranges from 32 to 40 per cent, and the nights are cool and often foggy. These two facts help to account for the serious splitting of Lob Injir figs in the latter district. Absence of summer fogs at Fresno means more hours of sunshine, lower humidity, and better drying weather. In Mediterranean districts, sundrying is successfully accomplished even in close proximity to the sea, where humidity is probably fairly high.

Wind is not an important factor in fig culture as far as the tree itself is concerned. Occasional strong winds may uproot mature trees which have poor root systems, especially if the ground has been softened by rain or by irrigation water. Gentle breezes during the drying season are welcome since they assist in the proper maturing of the fruit. Strong winds at the season of ripening whip the foliage and cause scarring of fruit, especially of such varieties as the Dottato; such fruit receives, of course, a lower grade and a lower delivery price. Windy weather during the

\section{Page 108}

\section{Condit 108 The Fig}

season of caprification may interfere with the normal flight of blastophagas and, if it is prolonged, may result in a poor setting of figs of the Smyrna type.

In his discussion of the climatology of citrus, H. J. Webber (1943) emphasizes the fact that little is definitely known on the subject. Since this is true of citrus fruits which have received the attention of so many investigators in various countries, it is not surprising that data on the climatic requirements of the fig are so meager. 


\section{PROPAGATION}

Fig trees are propagated by seeds, by layers, and by cuttings, and are topworked by budding or grafting.

Seeds: Propagation of fig trees from seed is employed only to produce new varieties as discussed in the chapter on fig breeding. Theo-phrastus tells of growing figs from seed and Ibn-Al-Awam in the 12th century in Spain gave directions for planting seeds and growing the seedlings. Eisen (1901) also contributes an account of fig propagation by seeds. Fertile seeds are readily separated from sterile seeds by immersing both in water; the former sink to the bottom and the latter float. Seeds germinate in a warm room as readily as tomato seeds, and the seedlings can be grown for the first season in temporary pots or properly spaced in flats.

Layers:Fig propagation by layering is practiced to some extent. Thomas J efferson wrote thus to a friend: "I have this spring laid down some of the young branches of my Marseilles fig, to take root, this method being more secure than that of cuttings." Massey (1893) reports that figs can be easily grown from layers. One method is to select a long shoot of the previous seasonl's growth, make a slanting cut half way through the wood, bend the shoot to the ground, and cover it with dirt, leaving the tip exposed in an upright position until fall. Another method is to place such a branch in a shallow furrow and cover young shoots with soil as they grow upwards. Each will root at the base and at the end of the season can be treated as a separate plant. According to Hagan it is a common practice in Smyrna fig districts to place a tin can filled with soil around the base of new shoots. When a good root system is formed, the whole shoot is transplanted to the desired location. Contrary to statements sometimes heard, fig trees propagated from layers or from suckers will produce just as good fruit as those grown from cuttings.

Stocks: The propagation of fig trees from cuttings is universally practiced so that little attention has been paid to the use of rootstocks. The subject does, however, merit attention. For instance, Estelrich recommends grafting Bourjassotte Noire on Bourjassotte Blanche in Spain in order to obtain a large tree in less time than on its own root. In Palestine the Smari variety is used in the Gaza district as a stock for the better varieties. It seems logical to conclude that weak-growing varieties propagated on a vigorous stock would respond in stronger growth, but no experimental data have been found regarding such reactions to stock. B. E. Dahlgren (1922) states that "in African Sudan where the fig has failed 
to grow on its own roots, it has been grown budded on the more tropical sycamore fig." In $1937 \mathrm{~J}$. M. Dalziel reported that Ficus gnaphalocarpa furnishes a good stock for the common fig and has been thus successfully used at St. Louis, Senegal.

The principal interest in stocks for figs is directed to securing one resistant to root troubles, especially that caused by the root-knot nematode. No variety of the Ficus carica complex has so far been found which shows sufficient resistance to or immunity from root-knot to warrant using it as a stock. One species, however, has been found which does show immunity to nematode attacks. It was introduced from Australia by the United States Department of Agriculture under P. I. No. 52406 and was later identified as Ficus glomerata. Common figs grafted on this stock in Florida grew vigorously at first but later died out. The stock is tender, leaves being injured by only 4 or 5 degrees of frost. For these reasons interest in this species as a possible stock has abated. A Florida nursery has, for a few years past, been grafting the common fig on stock of one of the two species of Ficus indigenous to that state. The stock is propagated by air-layering or, "mossing," established in gallon cans, grafted to the fig in the fall, and sold as a stock resistant to rootknot.

Cuttings: It may be presumed that in some prehistoric age, a native gardener found by accident that a fig branch or stake driven into the ground would root and start to grow. Thus fig propagation by cuttings was initiated, and the method gradually became so well established that no other is used commercially. Theophrastus says that the fig is propagated by cuttings more readily than any other fruit tree. His statement that in case the cutting "is set upside down, it does not shed its fruit and it makes a more accessible tree" must be taken with the proverbial grain of salt.

Two methods of growing fig trees are used in Europe planting cuttings directly in the ground where the tree is to remain, and planting in nursery rows for one or two years।' growth. The first method is apparently more widely practiced than the second. At Louie, Portugal, branches about 4 feet long and one inch in diameter at the base are planted full length in the ground. In southern I taly two cuttings are commonly planted in each hole to make certain of having one propagated. In Lecce Province the cuttings are made about 30 inches in length and $1 \wedge 4$ inches in diameter, and are planted in holes 3 feet deep. Some growers believe that bruising the cuttings by beating them against a rock will facilitate rooting. Others prefer to break rather than cut branches from the tree in the belief that the broken surfaces will present more contact with the soil. It may be such practices which have led some Italian scientists to conclude that the Dottato (Kadota) variety has degenerated and that a new variety should be developed from seedlings. Growing cuttings in nurseries for one or two years is practiced in Algeria, France, Greece, and the United States.

Fig cuttings are made in California during the pruning season, usually in 
January or February, the brush being worked up as rapidly as possible to prevent drying out of the wood. Tip cuttings may be used, but they are inclined to start terminal growth before a root system becomes established.

\section{Page 111}

\section{Chapter XII 111 Propagation}

Any wood up to two or three years of age may be used for cuttings so long as it is not too succulent or too pithy. Cuttings averaging about 9 inches in length with short joints and from Y\% to J 4 inch in diameter are preferred by nurserymen. Cuts are made with a pair of sharp pruning shears just below a joint at the base and just above a joint at the tip, the cuttings then being tied w. ith wire into bundles of 50 each.

If the basal cut is made straight across and the top cut made at an angle of 45 degrees, workmen will have less difficulty in planting the cuttings right side up. With plenty of good brush available, one man can cut, count, and tie from 3000 to 7000 cuttings in a day. When rootstocks for roses are made up into cuttings, the eye of all lateral buds is removed so as to prevent later suckering of the grafted plants; a similar practice with fig cuttings would relieve much of the necessity for suckering trees after they are planted in the orchard. Guglielmi (1908) recommends this practice for Lecce Province, Italy.

Considerable attention has been given in recent years to the use of various chemicals, such as indolebutyric acid, in stimulating rooting of cuttings of various plants. Some investigators report initial benefits in the treatment of fig cuttings, but most studies of this sort have been conducted on a small scale and have not been continued to the end of the growing season in actual nursery trials. Results reported by F. N. Harmon (1943) in treating grape cuttings with indolebutyric acid varied considerably with different varieties, and tests in their treatment with acid-talc mixtures did not show distinct commercial benefits. Experienced nurserymen are able to root untreated grape and fig cuttings so successfully and to get such vigorous growth from them that little interest is shown in the use of root-inducing substances.

Fig cuttings made in February can seldom be planted immediately. The bundles of cuttings are generally placed butt end up in a well-drained trench or on the surface of the ground and covered several inches deep with sandy soil, care being taken to prevent air pockets by sifting the sand thoroughly between the cuttings. The soil should be kept moist but not soaking wet, and the cuttings should be examined occasionally to see that they are not rotting or starting too rapidly into growth. Planting in the nursery is done as soon as the ground can be prepared properly, generally about March 15. The cuttings are then planted upright, full length, a few inches apart in furrows prepared with a plow or a shallow subsoiler, the rows being spaced 4 feet apart. 
Planting should be followed immediately by an irrigation, and soil moisture should later be kept sufficient to maintain a steady growth throughout the season. Suckers and laterals should be removed soon after they appear, leaving a single, unbranched trunk. Poor success in rooting cuttings may be due to the use of small or weak wood, to the drying out of the brush before making cuttings or during their preparation and handling, or to improper heeling-in of the bundles.

Fig trees are generally dug from the nursery at the end of one seasonl's growth by means of a special U-shaped cutter which runs beneath the tree row and severs the roots. The trees are then pulled, graded into three sizes of 2 to 3 feet, 3 to 4 feet, and 4 to 6 feet in height, and tied into

\section{Page 112}

\section{Condit 112 The Fig}

bundles of 10 trees each. These bundles are heeled-in in trenches of sandy soil until planting time. Trees left in the nursery for a second seasonl's growth should be cut back in March almost to the surface of the ground, only a single shoot being allowed to grow. Dormant buds push out better from such a one-year-old trunk when the tree is transplanted to the orchard. Fig cuttings may be taken from any tree or parts of the tree of the desired variety as long as healthy branches are used, for bud sports are so seldom found in fig trees as to be of negligible importance. Claims of superior strains or types of the Mission fig have not been substantiated, the superiority of the fruit usually being due to soil and climatic conditions rather than to a distinct strain of the variety. (See Condit, 1920\&.) Care should be taken, however, especially in Lob Injir orchards, to avoid making cuttings from stray trees of other varieties, such as the Stanford, which are not commercially desirable. Propagation of fig trees has been discussed by Eisen, Condit (1920a), and in various general publications on fig culture.

Budding: J udging from the account of Cato the Censor, budding and grafting of fig trees were done in the 3rd century B.C. in much the same way they are done today. Although budding has been practiced and described many times since, the impression seems to have become prevalent that the successful budding of figs is a very difficult operation. B. M. Lelong (1892) states that on account of its milky sap the fig is perhaps the most difficult tree to bud and suggests using a ring bud. Eisen reports that "fig trees are seldom budded, as grafting is much preferable. Still, if budding is desired as a curiosity it may be done." On the other hand, some California growers prefer budding to grafting since new branches produced from buds very seldom break off in the wind and those from scions often do. The suggestion of $G$. W. Oliver (1903) that a small twig with leaves attached be used rather than the ordinary shield bud hardly applies to large orchards or to a dry climate. 
The first prerequisite to success in any budding operation is to have the stock in a growing condition so that the bark slips easily. Two kinds of buds may be used for top-working fig trees, shield buds and patch buds. Shield buds are best placed in sucker wood in heavily pruned trees; patch buds may be used on older branches. Buds taken from succulent wood any time after spring growth is well advanced are inserted either in the ordinary $T$ or the inverted 1 incision. These are wrapped with three-ply cotton string, which should be cut after about three weeks. Buds placed in the stock during late summer will remain dormant until spring.

Patch buds are just what the name indicates. A patch of bark about 24 inch long and \% inch wide is slipped from the stock; another patch of the same size taken from a one-year-old branch of the desired variety is then inserted and tied in with cotton string or, preferably, waxed tape. In either kind of budding, the stock must be girdled or cut back in order to force out the bud.

Grafting:The usual method for top-working fig trees is grafting, most operators preferring the cleft graft to the bark graft. Successful cleft

\section{Page 113}

\section{Chapter XII}

\section{3}

Propagation

grafting has been done on thousands of young trees having branches up to 4 or 5 inches in diameter, by the following method: saw off the limb to be grafted; split the stub with a heavy knife or with a saw cut; insert a wooden wedge in the cleft to hold it open; with a thin-bladed chisel smooth the sides of the cleft. The next step is to cut 2 short scions, each having 2 or 3 buds, from firm wood of the desired variety, whittle them wedge-shaped, and with a small hammer drive each into place so that the cambium layers of scion and stock come into contact. Then carefully withdraw the wedge and apply wax so that every part of the exposed wood and cleft is well coated. Cleft grafting can be done early in the season before the bark slips.

Bark grafting is similar to budding except that a scion is used instead of a bud. It is done in the spring, when the bark is found to slip freely. Large limbs are cut back to stubs and a slit made in the bark for the insertion of each scion. The scion, with a sloping cut at the lower end, is then inserted into the slit and pushed firmly downwards until all of the cut surface comes into contact with the stock. Each scion is held firmly in place by a small nail or brad. After a sufficient number of scions are inserted into the stub, about 3 scions for a 4-inch stub, they are tied in place with strong twine and the 
exposed surfaces covered thoroughly with grafting wax or a water-asphalt emulsion. The bark of the exposed stubs and trunk is whitewashed to prevent sunburn. It is desirable that several scions grow on a large stub for a year or two until the cut end of the stock heals ove*, after which time the scions may be thinned out to the desired number.

Perforated paper sacks or newspaper should be tied around the stub and scions in order to protect them from the sun. In the case of bark grafting, strings should be cut or loosened whenever they show signs of cutting into the scion. Suckers which appear on the trunk or on stubs can be thinned out, although it is well to leave some of them to prevent excessive growth of the scions. An occasional pinching back of the growing scions may be necessary in order to prevent them from becoming top-heavy and breaking loose. It may even be found desirable to support the scions by means of strong laths nailed to the stock.

Top-working of fig trees has been discussed by Eisen, Roeding (1917), Condit (1923), and G. W. Beverley (1939).

\section{Page 114}

\section{Chapter XIII}

\section{FIG CULTURE}

Fig culture will be discussed under the following headings: Altitude, Soils, Spacing, Planting, Intercrops, Pruning, I rrigation, Fertilization, Tillage, Specialized Fig Culture.

Altitude:Altitude influences fruit-tree culture only as it affects temperature. In California, fig trees are successfully grown in depressions of 100 feet or more below sea level and at elevations of 3000 feet in the mountains. In Arizona, figs are produced at elevations of 4500 feet. In the Taurus mountains of Asiatic Turkey the trees luxuriate at 4800 feet, and near Nairobi, East Africa, they will grow up to 9000 feet elevation, doing best at about 6000 feet. However, most commercial fig districts are located at lower elevations in interior valleys or near the coast where winter climate is not severe.

Soils: Gould (1935) reports that light sandy soils in southern United States are low in fertility and subject to drought, and that many fig orchards planted on such soils have failed to produce satisfactorily. On the other hand, fig trees on well-drained, alluvial soils are characterized by strong growth and luxuriant foliage. In Texas the most important fig section is in the Lake Charles series of soils, which range from clay to fine sandy loam with the clay series predominating. 
Fig trees in California thrive on a wide range of soils. Many of those planted in light sandy soils have grown to be large trees bearing an excellent quality of fruit; many other fig trees planted in sandy soil have been attacked by root knot and have lost their vitality. At Merced, excellent Adriatic orchards are found on a very heavy, sticky clay soil with a hard-pan about 28 inches beneath the surface. Hardpan lands of the Madera and San J oaquin series, with tree holes blasted in order to provide for deep root penetration, are being successfully used for fig culture. Some of the best Mission fig orchards are located on deep, rich, river-bottom soils having an abundant moisture content. Soils having a water table closer than 6 or 8 feet to the surface or a water table which fluctuates during the year should be discounted for fig culture.

Alkali soils should be regarded as submarginal for figs. A. Aaronsohn (1910) found wild figs growing on black alkali soil near Fusail, Palestine, and suggested their use as stocks for cultivated figs in California. T. H. Kearney (1936) reports that pear and fig trees are fairly resistant to soil salinity so far as the growth of the trees is concerned, but that the quality of the fruit suffers if more than a limited quantity of salts is present. E. W. Hilgard (1912) published a table indicating the highest amount of alkali in which fruit trees were unaffected. However, the most important con-

\section{Page 115}

\section{Chapter XIII}

lis-

Fig Culture

sideration is not the total salts but the kind of salts present. Fig and other fruit trees will tolerate a considerable amount of sulphate or white alkali in the soil but may be seriously injured by a relatively small amount of sodium carbonate or black alkali.

Spacing:The spacing of fig trees in an orchard varies greatly in different countries and with different varieties. According to Plutarch, a decree of Solon stipulated that no one should plant a fig or olive tree within 9 feet of his property line because its roots might interfere with the growth of a neighbor 's trees. Badie and Ghamrawy (1931) report that in Egypt, trees of vigorous growing varieties, such as Sultani, are spaced at 16 feet but that less vigorous ones are planted 11 feet apart. Portale (1910) recommends planting from 110 to 160 trees per acre in specialized fig orchards at Mistretta, Sicily. Siniscalchi (1911) suggests 25 to 33 feet as the proper spacing for Dottato trees in the Cilento district. In fig districts near Smyrna, trees are planted from 35 to 55 feet apart. 
In southern United States close planting is practiced. Earle (1897) advised the setting of 200 fig trees per acre since crops of the first few years would be double those secured from planting half that number. Starnes (1903) suggests spacings from 10 to 20 feet in Georgia, while Reimer (1910) recommends 10 to 12 feet for semi-dwarf varieties and 15 to 20 feet for more vigorous trees such as Celeste. Brunswick (Magnolia) trees in Texas are spaced 17 to 18 feet apart.

In California, fig trees are generally planted on the square system, the spacing depending upon the variety. Lob Injir (Calimyrna) trees, with an upright habit of growth, are spaced from 30 to 36 feet apart. Adriatic trees, which naturally have a spreading habit of growth, require from 32- to 40-foot spaces, but Mission trees need a spacing of at least 40 feet. Some growers plant Mission trees from 20 to 25 feet apart and remove alternate trees later when they begin to crowd. Dottato (Kadota) and San Piero trees, the fruits of which are generally harvested fresh, are commonly crowded together and the trees pruned low in order to facilitate picking of the crop. On the square system the trees are usually spaced from 20 to 24 feet, although some growers prefer to set the trees closer in the row and to space the rows 16 to 18 feet apart, a system allowing cultivation and irrigation in one direction only.

Planting: Rooted fig trees may be planted at any time while they are dormant if the soil is sandy and well drained. If the orchard site is well prepared in advance, the holes need to be just large enough to receive the tree roots. In Europe, however, it is a common practice to dig holes 3 to 4 feet across and the same in depth. These large holes are refilled with top soil and any organic material which is readily available. On land which has been grainfarmed for long years, a good procedure is to subsoil along the tree row and also at right angles so that tree holes can be dug at intersections. Some California growers use the European system of planting cuttings in orchard form directly, without resorting to the use of nursery trees. Large cuttings at least 12 inches long are set in the designated places and watered regularly during the first season.

\section{Page 116}

Gondit

116

The Fig

The method of planting a fig tree differs very little from that used for any other deciduous fruit tree. The roots, being very susceptible to drying out, should be protected during the transfer from nursery to orchard and at 
planting time. Excellent results can be secured by heeling-in small lots of trees in convenient places near the orchard and by distributing to the planters only small numbers of trees at a time. Since the trees are on their own roots, they may be advantageously planted from 2 to 4 inches deeper than they stood in the nursery row.

After being planted, the trees should be headed back, the height depending upon the method to be used in harvesting the crop. The ideal system is to head the trees high and to have main framework branches spaced along the upper 18 inches of the trunk; such spacing may avoid bad crotches and the necessity of bolting or bracing the tree in future years. Trees are usually headed at about 24 inches, but Dottato and San Piero are started somewhat lower. Newly planted trees should be irrigated at once.

Intercrops: The interplanting of fig and other fruit trees or vines is a common practice in Europe. Association of fig trees and grape vines is satisfactory in I taly for $\mathbf{2 5}$ or $\mathbf{3 0}$ years; after that time the vines decline and should be removed. In the association of fig and olive trees, it is the fig which declines after about 40 years and the olive which persists. Vegetables, which are generally fertilized, are regarded as a good intercrop for a fig orchard. Cereals, on the other hand, are found detrimental to the proper development of trees.

In California very few growers have found intercrops which are satisfactory. Experience has shown that it is better to double plant the same variety of fig than to interplant with some other fruit tree. The characteristic border rows of fig trees, mostly of the Adriatic variety, are gradually disappearing from vineyard districts of the San J oaquin Valley. Once called "mortgage lifters,, because of their bountiful and profitable crops, these trees are now decadent and usually produce only low-grade fruit.

Pruning: The main reasons for pruning fig trees are: (1) to produce mechanically strong, healthy trees capable of producing heavy crops over a long period of years; (2) to facilitate, in some varieties, the harvesting of fresh figs; (5) to stimulate the production of vigorous branches which will bear second-crop figs over a long season; (4) to prevent decadence of bearing trees. The fig tree, unlike the peach or apricot tree, normally bears two crops each year, the first crop appearing on wood of the previous season, and the second crop on new wood of the current season. Since pruning methods which apply to one variety of fig cannot be practiced successfully on certain other varieties, pruning of each of the principal varieties will be discussed separately.

Adriatic and Mission Trees. Young Adriatic trees require little if any more pruning than the removal of lower, spreading branches and a certain amount of thinning of the interior branches where they become too thick. Branches of bearing Adriatic trees have a tendency to droop with the weight of fruit and leaves so that the upper sides of the branches be- 
Chapter XIII 117 Fig Culture

come sunburned. Annual or biennial pruning throughout the top of the mature trees should obviate the necessity of heavy stubbing-back because of sunburned branches. The aim should be to promote the production of new vigorous wood and to prevent the accumulation of a dense growth of short, weak twigs.

The Mission tree, like the Adriatic, branches freely and produces an abundance of laterals. Proper selection and spacing of the framework branches is more important for the young Mission tree than for most other fig trees because the main branches generally form an acute angle at their junction with the trunk and have a tendency to split away from it under the weight of leaves and fruit. Central wire bracing is sometimes used to prevent such damage. Heavy pruning or stubbing back of Mission trees should be avoided since sucker wood resulting from such pruning is notably unproductive.

Lob Injir Trees. Lob Injir fig trees tend to produce long upright branches without laterals. The pruning problem with this variety is, therefore, to produce trees and branches which are capable of standing upright under future heavy crops. This is not a serious problem if the trees are only moderately vigorous, for dormant buds on the upright branches usually push out into laterals in sufficient numbers to thicken up the tree and to* prevent the top-heavy condition seen in some orchards.

There are two different methods that may be used to shorten the intervals between laterals in vigorous Lob Injir trees: winter pruning and summer pruning. Winter pruning consists in cutting back the upright branches to stubs each year until the tree develops sufficient bearing surface to slow down the length growth to more moderate proportions. Such heavy cuttingback will eventually produce a symmetrical tree, but it will delay the time of first production. Summer pruning consists in pinching back or breaking off in early summer 3 or 4 inches of the terminal growth. This results in checking the growth for a few days, after which time from one to three laterals push out. Summer pruning has considerable merit if it is continued systematically, but it should be used only on vigorous trees and should be done early enough to insure a long season of growth.

The pruning of bearing Lob Injir trees in California consists of an occasional thinning-out and heading-back of the top in order to stimulate a constant succession of new vigorous wood on the main framework branches. The cutting out of fairly large branches throughout the top is preferable to the stubbing-back of small branches. The latter system is being used on a 
considerable scale in one California district, the results of which may be summarized as follows: vigorous short growth with dense dark-green foliage, late season of caprification and maturity of fruit, lighter crop than on trees not so heavily pruned, smaller size but excellent quality of figs. According to Hagan, pruning of Lob Injir trees in the Meander Valley is practiced mainly to remove dead or broken limbs.

Dottato Trees. In California, Dottato fig trees are trained low to facilitate economical harvesting of the crop. The young tree is headed at about 12 inches, and from 3 to 5 framework branches are allowed to develop at intervals on the trunk. Each winter the vigorous new branches

\section{Page 118}

\section{Condit}

118

The Fig

are cut back to short stubs, the inside branches being pruned shorter than the outside branches. A low, nearly flat-topped tree is thus secured. On one side of it a passageway is kept open to make it easy for pickers and pruners to walk up to the center of the low-spreading tree.

However, experimental plots have shown that Dottato trees given minimum pruning by lightly thinning out the centers and suppressing the topmost branches have, in the first four seasons after they were planted, produced over three times as much fruit as have neighboring trees which were heavily pruned each winter. By a continued suppression of the top at the desired height and a moderate thinning-out of the lower branches, trees can be so maintained for several years and the fruit harvested economically. Unpruned Dottato trees are inclined to produce short-jointed twigs; each of these bears several figs but does not produce enough leaves to nourish the maturing fruit properly. A judicious thinning out and cutting-back of some branches is therefore advisable.

San Piero and Brunswick Trees. San Piero fig trees grown in the desert regions of California are pruned in early summer shortly after the first crop is harvested. Such pruning stimulates new growth productive of fruit later in the season when the market is not well supplied with figs from other districts, and it also provides fruit wood for the early spring crop. In districts nearer the coast, growers market the second crop only and therefore practice heavy winter pruning. San Piero is remarkably productive under such treatment.

Stansel (1931) reported that in pruning tests with Brunswick fig trees in 
Texas, lowest yields were produced on severely pruned trees, and the largest yields, as well as the largest figs, on unpruned trees. The 4-year average yields were as follows: severe pruning, 1137 pounds; light pruning, 8562 pounds. The method commonly used in commercial orchards of Texas is intermediate between severe and light pruning and consists in cutting back the new growth each year to 7-inch stubs.

Caprifig Trees. Young caprifig trees are generally headed low so that later crops may be picked economically. During the first few years the only pruning necessary is the removal of suckers and interfering branches. Since the mamme crop of mature caprifig trees is usually valuable, heavy winter pruning is not generally practiced. If it is necessary, some thinning-out of branches may be done in midsummer after the harvesting of the profichi crop.

Special Pruning Practices. An operation known as terminal bud pruning of figs has been practiced for many centuries. J ean de La Quin-tinie (1693) stated that the removal of terminal buds in early spring "serves to make the fig shoot out the sooner and consequently to ripen fruits sooner, since the first that come out of the tree are always the first ripe upon that tree." It is apparently this practice to which Columella and Pliny referred. The latter stated that if the tip of each branch was removed just as it began to put forth leaves, the strength and productiveness of the tree were greatly increased. The practice is a common one in France, especially at Argenteuil, and is described and illustrated by Auguste and Gustave Riviere (1928).

\section{Page 119}

\section{Chapter XIII 119 Fig Culture}

In California, terminal disbudding is used only in the Coachella Valley, on the San Piero variety, as described by R. W. Hodgson (1926). Removal of the terminal bud is done either with a knife or with hand shears about two weeks before the buds normally become active. Recent experiments at Riverside show that disbudding of San Piero causes not only an earlier swelling of lateral fruit buds but also a much more profuse setting and maturing of fruit. Thus, on 14 trees not disbudded there matured a total of 98 figs, or 7 per tree; on 16 trees disbudded there matured 981 figs, or 61 per tr\#e. The results of disbudding on $\mathbf{2 4}$ other varieties have been mostly negative.

Special methods are sometimes used to stimulate the production of laterals on vigorous, upright fig branches. One is the bending of such branches from a vertical to a horizontal position. Another, used in India, is described by S. R. Gandhi (1924) as "notching." This method consists in cutting notches through the bark and into the wood above dormant buds.

Specialized fig culture in some countries requires special pruning practices one of which is summer pruning. R. H. Price and E. A. White (1902), for 
example, state that by summer pruning "the growth is checked and numerous fruiting spurs of matured wood are formed, each bearing one or two good sized, well formed figs. The more of these fruiting spurs a tree has the more productive it is and the finer the quality of the fruit." Again, Victor Miranda (1915) advocates the following treatment for young fig trees in Spain:

Fig trees, until they have been growing for two years, should not be pruned, leaving all the twigs that come out of the trunk so that it will become larger and more robust. Sometimes the growers, however, begin to form the tree during the first year by suppressing with the fingers the sprouts as they appear.

Irrigation:Modern fig growers will hardly adopt the method of irrigating fig trees said to have been used in 16th-century France. According to Mrs. W. B. Bernard (1866), cisterns were placed under the trees and water was conducted by wicks of worsted threads, thus "diffusing moisture among the branches and also dropping down among the roots."

In fig districts of the Old World, orchard irrigation is the exception rather than the rule. The water table in the Meander Valley is from 10 to 30 feet below the surface, and rainfall is apparently sufficient to make surface irrigation unnecessary. Grasovsky and Waitz (1932) state that irrigation, if practiced at all in Palestine, should be done during the rainy season and not in spring or summer since it would then interfere with the proper maturing of the fruit. There is a general belief among some Spanish fig packers that although trees grown in gardens or on irrigated land produce heavily, the fruit spoils easily or is of poor quality in spite of the fact that most of the famous Fraga figs are grown on irrigated river-bottom land.

In southern United States, rainfall is generally sufficient to maintain fig trees in good condition and to mature a crop. For North Carolina, however, Reimer (1910) advocated irrigation during dry seasons in September and October when the bulk of fruit is ripening. In California the

\section{Page 120}

Condit

120

The Fig

irrigation of fig orchards is a necessary cultural operation except where the water table is high. 
An irrigation experiment with four plots of fig trees was carried on at Riverside during the period from 1928 to 1938 . Trees heavily irrigated twice a month showed in 1938 an average trunk circumference of 793 mm; trees irrigated once a month averaged $714 \mathrm{~mm}$; those irrigated only once during the season measured $656 \mathrm{~mm}$; and unirrigated trees averaged only $520 \mathrm{~mm}$. Of the four varieties planted in the irrigation experiment, Lob Injir was the lightest producer of fruit and averaged the largest in trunk circumference; San Piero, the heaviest producer, averaged the smallest in trunk circumference. Mission trees averaged larger than Dottato although the two varieties were approximately equal in production.

Weak growth of fig trees and the resulting lack of foliage are often due to a deficiency in soil moisture. When young fig trees come into bearing, the tree itself is the best index of its water requirements. Excessive growth is undesirable since it needlessly increases the size of the tree and the prevalence of splitting and souring. Moderate growth for bearing Cali-myrna, Mission, and Adriatic trees means an increase of about 5 to 7 inches in length of terminal twigs each season. The number of irrigations and the amount of water necessary to keep the soil above the permanent wilting percentage and to prevent premature leaf drop cannot be told with certainty for any particular orchard but should be determined by the experience of the individual grower. Methods of applying irrigation water to fig-orchard soils are not essentially different from those used in other deciduous orchards.

Fertilization:Fig orchards of the Smyrna district seldom receive any animal or commercial fertilizers, but reports of their occasional use have shown increases in yield. In Huelva Province of Spain, fig trees are not fertilized directly, but manures and other refuse are applied to the intercrops between the rows. Estelrich goes into detail on the subject of fertilization of Mallorcan fig orchards, but the advice seems to be largely speculative rather than based upon actual fertilizer trials or extensive experience.

Fertilizer experiments conducted at the Angleton and Beaumont Stations of Texas were largely nullified by the fact that the plots were not far enough apart and roots of one set of fig trees crossed beyond a single guard row into a second plot. Sulphur application resulted in a reduced yield of figs, and its use as a soil amendment is not recommended for Texas.

In considering the maintenance of soil fertility in California, certain facts should be kept in mind. One is that vegetative growth induced by the application of nitrogenous fertilizers to bearing fig trees sometimes does not mature in time to escape early fall frosts. Another fact is that the vigorous branches which fertilization may produce have a tendency to bear large fruits, and these, as stated earlier, are susceptible to splitting and souring. Some growers therefore practice spot fertilization, that is, application of material only to those trees which show by poor color of foliage or by weak twig growth their apparent need of a fertilizer. The application 
Chapter XIII

121

Fig Culture

of some bulky organic material such as bean straw, alfalfa hay, or barnyard manure is advisable if it can be obtained at reasonable prices.

There is a very general impression that the fig tree is a "lime-loving" plant and that the application of lime to the orchard soil will therefore be decidedly beneficial. But most soils in California are well supplied with lime. In a Modesto fig orchard the application of amounts of lime varying from 3ij4 to $10 \mathrm{j} \wedge$ tons and of gypsum up to Zy 2 tons to the acre resulted in no evident improvement either in soil condition or tree behavior. According to Gould, the application of lime in the southern states, either separately or with a complete fertilizer, showed no significant results.

Tillage: The major purposes of tillage are to facilitate the distribution of irrigation water, to incorporate organic matter with the soil, and to eliminate the competition of weeds for the available soil moisture. On rolling, uneven land it is a common practice to ridge up the ground into contour checks to prevent erosion in periods of heavy rainfall. Spring plowing or disking to turn under the covercrop, either natural or planted, and light cultivation as often as necessary to destroy weeds are the usual practices. Clean culture and a smoothing of the surface soil in drying-fig orchards facilitate the picking up of the fallen fruit.

In 1907 Starnes suggested that an established fig orchard in Georgia be put into Bermuda grass and thereafter be mowed but not plowed. On the other hand, Stansel and Wyche (1932) stated that in Texas "figs respond readily to good cultivation and for best results the orchard should be kept free from weeds or grass (especially Bermuda grass). An orchard that is not cultivated soon ceases to produce profitable crops." Gould emphasized the importance of using tillage implements which destroy weeds without cutting deep and cited instances of serious root injury by deep tillage.

The maintenance of a heavy mulch under fig trees at all times was advocated by Reimer in 1910. Surface mulches are a dangerous fire hazard in a dry climate. Straw mulch versus clean culture of fig trees received experimental attention in Mississippi between 1925 and 1931. J, L. Cooley in 1930 and W. S. Anderson in 1931 reported that trees mulched with straw produced 95 per cent more fruit and 50 per cent more foliage than those in the clean culture plots and that trees in the mulched plots showed definite cold resistance. Both Lemon and Celeste produced fruits almost twice as large under mulch 
culture as under clean culture.

Cultural conditions in European fig orchards vary greatly. In many cases cultivation is practiced for the intercrops rather than for the fruit trees, hoeing out weeds and working up the ground by hand being normal procedures when sufficient man power is available. In Smyrna fig districts clean culture is practiced. Growers plow the land after the first rains, again in March, and sometimes in J uly after caprification.

Specialized Fig Culture:Cultural methods used for fig trees in central France, in parts of England, and in India, are so specialized as to warrant particular attention. The following details of fig culture near Paris

\section{Page 122}

\section{Condit 122 The Fig}

are given by Alphonse du Breuil (1876), by Eisen (1901), and by Edmond J uignet (1909). Fig trees are planted S to 6 yards apart and the branches covered with earth during the first two winters. Early in the third season the trees are pruned to within 6 or 8 inches of the ground and the new branches are trained into a low, spreading form. In November all leaves and green figs are removed and the branches tied into four bundles, each of which is then laid in a trench and covered with a foot of soil, the surface of which is rounded in order to shed water. Uncovering is done in March during cloudy weather, the branches being carefully arranged and propped up so as to give ample spacing. Terminal buds and superfluous twigs are carefully removed. After the crop is gathered, branches which have fruited are cut off and the wounds covered with wax. Trees come into full production at ten years of age. In subsequent years some old branches are discarded and new ones allowed to form from basal suckers.

In England, fig trees are grown out of doors as espaliers on walls, as standards, and as dwarf plants in pots. E. A. Bunyard (1934) recommends using walls with southern exposure because of the extra light and protection they afford. The ideal form, however, is the standard or spreading bush, the branches being tied to a horizontal trellis.

Fig culture in 12-inch pots tends to restrict the roots, to check vigorous top growth, and thus to promote fruitfulness. Pot-grown plants do not produce such large figs as do plants in open ground but, according to Bunyard, "they more than make up for this by an added sweetness."

Figs have long been grown under glass, especially in England. The Royal Gardens at Kew had a fig house 50 feet long which in 1810 supplied the royal tables with more than 200 baskets of figs, one-fourth from the first crop and 
the rest from the second crop. In one season, excellent figs were supplied for the Queenl 's birthday, the 18th of J anuary. In 1846 there was at the Palace of Versailles a "forcing house,, in which figs were grown out of season. Detailed accounts of fig culture in a glasshouse are given by David Thomson (1881) and by various other horticulturists. The trees, grown in pots not over 12 inches in diameter, can be shifted around and given favorable conditions for growth and fruiting. Those set in the ground should have their roots restricted by root pruning or by confinement in cement basins, for otherwise they are inclined to grow luxuriantly at the expense of fruitfulness. Plants already in pots and those propagated by layering in the spring can be repotted in September, given a moderate degree of heat in winter, and induced to mature a first crop in May. By repotting the plants still earlier, ripe figs can be secured during the winter. The following varieties have given a long succession of ripening figs in English glasshouses: White Marseilles, Madeleine, San Piero (Negro Largo), White I schia, Black I schia, Grosse Verte, Bourjassotte Grise, Col de Signora Blanca, DI'Agen.

An unusual cultural practice is found at Poona, India. During a break between rains in September, growers uncover the main roots of fig trees within a radius of 2 to 4 feet from the trunk, cut fibrous and small roots, and leave the hole exposed to the air, the idea being that dormancy of the trees is thus induced. At the end of two weeks baskets of cow manure and

\section{Page 123}

\section{Chapter XIII 123 Fig Culture}

other organic matter are dumped into the opening and the top soil returned to its former place. This practice shortens the life of fig trees, causing them to die out or become unprofitable after 25 years. Experiments reported by $\mathrm{C}$. K. Subba Rao (1908) at Pusa indicate temporary beneficial results from this "weathering" of the roots.

\section{Page 124}

Chapter XIV

\section{THE FRESH FIG CROP}

Yields: According to A. Rolet (1916) fresh fig production near Toulon reaches from 7000 to almost 9000 pounds per acre. Other figures on European production per unit of space are scarce. We know, however, that the total production is large, that great quantities of fresh figs are sent to the markets, and that other large quantities furnish food to the peasants. 
In the United States, Brunswick (Magnolia) trees produce a maximum of 6000 pounds of fresh figs per acre with the average production about half that amount. An orchard near San Leon, Texas, has produced 4000 pounds per acre, but in 1940 the yield was cut to 1400 pounds by the previous winter I's cold. A 200-acre planting near Friendswood produces about 3000 pounds per acre. In California, San Piero (Brown Turkey) trees grown under a system of heavy winter pruning are very productive from late J uly to frost. Dottato (Kadota) trees also yield heavily, up to 8 tons per acre in the San J oaquin Valley with yields in large plantings averaging 5.5 tons. In 1941 an 18-acre orchard in Tulare County produced 144 tons of fresh Dottato figs, 116 tons being used for canning, 11 tons for fresh fruit shipping, and 17 tons for culls.

Only occasional Mission or Lob Injir orchards have the entire crop marketed as fresh fruit. First-crop Mission figs, commonly marketed fresh, produce from 2.5 to 3 tons per acre; Lob Injir figs of the main crop yield about the same tonnage of fresh fruit.

Picking: Pickers of fresh figs usually wear cotton gloves as a protection against the acrid fig juice, carry a hooked stick to pull down branches, pick figs by twisting the neck loose or sometimes by cutting it with a knife, and deposit the fruit carefully into picking boxes or into shallow trays. Some pickers can handle figs without difficulty, but many persons suffer serious skin irritation due to latex unless afforded some protection such as lubricating oil or grease smeared over the skin. Gasoline or vinegar readily removes the gummy latex from the hands or from gloves.

The relative merits of twisting or pulling fresh figs from the branches versus clipping or cutting with a knife were discussed in the Blue Anchor for September, 1926. Figs cut cleanly from the stem make a much better appearance in the package and theoretically should keep better during marketing. In storage tests, however, fresh figs started to mold as commonly on the side as at the stem end and whether they were cut or pulled from the tree, indicating that the skin of the fig, especially if it is slightly abraised, offers little resistance to mold growth. Experienced pickers are able to pull or twist the stems of figs loose from the branches without serious injury to the fruit.

\section{Page 125}

Chapter XIV

125

Fresh Fig Crop

Special devices are sometimes used for picking figs which are out of reach of 
the hand. Portuguese growers select a long cane, carefully split the thin end 4 or 5 inches deep, tie the split parts to form a cup, and slip this over a ripe fig so that it is readily separated from the tree. Another device consists of a bamboo pole with one end split into two parts separated by a wedge. Across the end of the fork is strung a wire, below which hangs a miniature basket; when the picker pushes the wire against a ripe fig, it is detached and falls into the basket. Starnes (1903) illustrated a homemade fig picker consisting of an empty tin can tacked to the end of a stick. A California grower successfully picks San Piero figs by means of a wire cup attached to a pole.

Some fruits, such as the pear, can be picked green and then marketed in better edible condition than when they are tree ripened. Unfortunately, the fresh fig picked green-ripe never approximates the eating quality of a fig allowed to ripen and reach its full sugar content on the tree. The proper color and stage of maturity of figs must be learned from experience and from reports given by the distributor in the consuming market. Figs too green carry well but are unpalatable and do not create a desire for more; figs too ripe are inclined to "leak" at the eye and develop spoilage diseases either en route or on the retail market. While color is a good indicator of maturity, it should not be relied upon implicitly. For instance, Lob Injir figs picked straw to yellow in color and apparently ideal for shipping arrived in New York too ripe for safe distribution on city markets. A stage of maturity halfway between the above and the plainly too-green stage appears to be proper for the picking of fresh Lob Injir figs for shipment. Mission figs intended for the market are picked when purplish black in color but still firm.

Half-dried Mission figs also are shipped successfully from some California districts. The figs are either picked from the tree or gathered from the ground as soon as they fall. Then they are cleaned with hot water, dried to a soft pliable condition, and packed two layers deep in trays. They are consigned in small lots and only to markets which are familiar with the product. Specifications issued to shippers by the California Fruit Exchange state:

Figs, in order to grade Blue Anchor, must be mature but not overripe, free from excessive blemishes and defects, and shall not be excessively sunburned, sour, split or cracked. . . . Partially dried figs shall be bright, clean, and free from excessive dirt and foreign material.

For the cannery, Dottato figs are picked when mature and of a yellow color, by giving the fruit a slight twist which removes it but leaves the stalk on the branch. Each picker uses an 8-quart galvanized bucket suspended from the shoulders by a canvas strap so that both hands are free. Two buckets fill the average field box with 20 pounds of figs. Pickers average from 900 to 1000 pounds of figs in an 8-hour day at the height of the season and are paid 18 cents per box; they may average only half that amount when the fruit is ripening slowly and are then paid 75 cents per hour. Field boxes full of figs are transported at night by trucks to the cannery, which may be 100 miles or 
more distant from the orchard.

Condit

126

The Fig

According to Stansel and Wyche (1932), Brunswick figs should be picked before they become thoroughly ripe, in what is commonly called the commercial stage, when they have turned from a green to a yellowish color but have not yet become soft. Investigations in Texas by H. P. Traub and G. S. Fraps (1928) show that harvesting of the canning fig shortly before it is tree-ripe is justified "since the net gain in sugars and other constituents after the commercial stage is reached, is not sufficient to warrant delay in harvesting." Texas figs, picked by a twisting motion which separates the stem from the tree, are first put in buckets and then dumped into shallow 40pound field boxes. One man can pick from 100 to 300 pounds per day according to the season. It is estimated that from 10 to 20 per cent of the Texas fig crop is sent to the fresh fruit markets of near-by cities.

Packing and Shipping:One of the pleasant recollections of a sojourn in the city of Smyrna is that of hearing the early morning cry of the fig peddler, "Bardajik! Bardajik!" and seeing him coming down the street with fresh figs packed in panniers suspended on each side of his donkey. This direct route from producer to consumer presented no packing difficulties. For the successful shipping of fresh figs, careful handling is necessary. As early as 1692 La Quintinie instructed French growers to wrap figs in vine leaves, to pack them tightly into a box not over two inches deep, to cover them with more leaves and a sheet of paper, and then to ship them to market.

Under normal conditions in southern France, figs are picked into burlap-lined baskets, sorted and sized carefully, and packed into cartons. The packed cartons are shipped on an afternoon train and are on sale in Paris early the next morning, or in London a day or so later.

For local markets in California, figs are usually packed in one-layer rectangular flats containing about 6 pounds of fruit with crosswise paper or card board fillers between the rows. Mission figs are sometimes marketed in lug boxes 2 or 3 layers deep.

Shipping of fresh figs from California to eastern markets of the United States began in 1884 when they were sent in small lots from Vacaville. It was then predicted that if refrigerator cars were available, figs would carry well in large 
quantities. Portable ice boxes with removable trays, called "pony refrigerators" and described by Thomas Elliott in 1917, have been used for shipping fresh figs and other perishable fruits long distances, but it was not until J une, 1921, that the first full car of fresh figs, consisting of the Mission variety, was shipped from California by express. Twelve other cars, mostly of the Lob Injir variety, were shipped during the season by express and freight. One shipping company reported an average of 2 per cent decay at point of delivery for those sent by express and 20 per cent for those sent by freight. Car-lot shipments of fresh figs since 1921 have varied considerably in total number for the season. For example, there were 134 cars sent to market in 1929 and 130 in 1940, while in 1933 only 22 cars were forwarded. During 1943 monthly car-lot shipments of California

\section{Page 127}

\section{Chapter XIV}

\section{7}

\section{Fresh Fig Crop}

fresh figs were as follows: J une, 16 cars; July, 1 car; August, 16 cars; September, 18 cars; October, 14 cars; and November, 1 car. New York City takes over 90 per cent of California fresh figs although a few cars each year go to Boston and to Chicago. Shipments by fast freight, especially of Dottato figs, are increasing in volume. It is of prime importance, however, that boxes of packed figs to be shipped by freight be precooled before they are loaded and that cars with large ice capacity be used. High prices for canning figs and for dried figs during war years have tended to induce growers to market the crop in these two forms rather than risk the uncertainties of the fresh fruit market. Less than carlot (1. c. 1.) shipments, by which some figs are shipped in a car containing apricots or other fresh fruits, have been popular in past years and still are forwarded from some districts. Table 5 gives car-lot shipments of California figs during recent years.

Table 5.Interstate Shipments California Fresh Figs by Counties in Car Lots:

San

YearFresnoJ oaquinStanislausTulareMercedTotal

1932-39

average 183211,8 
19411741911886

1942303031064

1943272775066

\section{3}

The four varieties of figs commonly used for fresh fruit shipping in California are San Piero, Mission, Dottato, and Lob Injir. The first is grown mostly in southern California and is marketed locally. Mission figs of the first crop are almost ideal for fresh fruit shipping and are consigned in large quantities to distant as well as to local markets. Second-crop Mission figs are mostly too small in size for eastern shipment but are plentiful on local markets. Dottato figs of the second or main crop carry especially well to distant cities. Lob Injir figs are large, attractive in color and appearance, of a good shape for packing, and carry well when properly handled.

A few years ago two packs were commonly used. One was a square wooden tray containing four shallow baskets into which the figs, usually wrapped with paper, were packed. The other was a rectangular box into which an "egg cell" filler was placed to hold the fruit. In recent years two packages are listed by the Freight Container Bureau of the Association of American Railroads. One package known to the trade as "fig flats," is 11 inches wide, 16] ^ inches long, and from $1 \%$ to 2 inches deep. Fillers are commonly used in this package and the figs are not wrapped. The second package is called the "fig crate" and the dimensions are the same as the "fig flat" except for the width, which is 16 inches. Wrapping of figs has been discontinued because of the labor and expense involved and because unwrapped figs are no more inclined to mold than those wrapped in paper. The material advantage of the egg-cell filler is that no two figs touch and there is little or no shifting of the fruit back and forth in the box

\section{Page 128}

Condit

128

The Fig

during transit. The boxes of packed figs are assembled at a central plant where they may be held in a cool room for a few days although prompt shipment is advisable. Precooling for about 12 hours lowers the temperature of the fruit to $340 \mathrm{~F}$. A standard car contains an average of 3170 fig boxes 
each weighing 6.7 pounds.

Various treatments to improve the keeping quality of figs and other fresh fruits have been tested experimentally. The coating of figs with paraffine or mineral oil may improve shipping quality but such materials are objectionable to consumers, especially in warm weather. Treatment of fresh figs with sulfur dioxide has been tried in California with disappointing results since the quantity necessary to repress decay injured very seriously the color, texture, and flavor of the fruit. In Texas, Reed (1936) concluded after various experiments "that with proper packing, refrigeration and possibly the use of mild dosages of sulfur dioxide, the spoilage loss of Magnolia figs during shipment can be considerably reduced." Experimental tests with carbon dioxide have indicated promising results in the control of mold without injury to the flavor or the appearance of figs. \{See C. Brooks et al., 1936.) The placing of 1000 pounds of dry ice in a refrigerator car results in an early carbon dioxide concentration of 15 to 30 per cent which has gradually become reduced to 1 or 2 per cent upon arrival two weeks later.

That the fresh fig stands in a class by itself as far as distant shipments are concerned is indicated by this statement of F. W. Read in 1929:

Fig prices on the fresh article in 1929 were on the whole very unsatisfactory. It appears that every year we run into new difficulties. First the fruit is too ripe, next it is too green, at times it is packed poorly, but usually something is wrong. It is certain that of all fruits handled in the fresh state, none is more difficult to ship.

That the shipping of fresh figs from southern United States is also unsatisfactory, is indicated by the following report of J. G. Woodroof and J. E. Bailey (1930):

The inability of fresh figs to stand shipment militates against the commercial fig industry in the South. This difficulty is largely due to the fact that figs do not ripen after being picked. To develop the best eating qualities they must remain on the plants until fully ripe, and by this time they are soft and will not stand the necessary handling in picking and shipping.

Gold Storage: Fresh figs are seldom held for any prolonged period in cold storage. Experiments with several varieties in Hawaii by E. V. Wilcox and C. J . Hunn (1914) showed that figs picked in the proper degree of ripeness for table use could be held at $320 \mathrm{~F}$. for a month in excellent condition. W. J . Williams (1935), on the other hand, reported that Australian figs held at 500 F. with a relative humidity of 85 per cent kept well for 21 days, but at 350 they could be held for only 14 days. In 1941, G. S. Cheema kept Poona figs in a sound condition for about a month at 320 and $350 \mathrm{~F}$.

In storage tests reported by W. T. Pentzer and C. E. Asbury commercial packs of Lob Injir figs held well for two weeks at $320 \mathrm{~F}$. and 85 per cent 
humidity but became badly molded when held much longer. At 400 to $430 \mathrm{~F}$. and 75 per cent humidity, figs kept well for about eight days

\section{Page 129}

\section{Chapter XIV 129 Fresh Fig Crop}

without any mold development. When taken from such storage temperatures, fresh figs hold up well on the market for only one or two days.

Freezing:Several investigators have reported on the preservation of fresh figs by freezing. Among these are E. L. Overholser (1922), M. A. J oslyn and W. V. Cruess (1929), J. G. Woodroof and J. E. Bailey (1930), W. T. Pentzer and C. E. Asbury (1931, 1932), D. G. Sorber (1935), E. H. Wiegand (1936), and H. M. Reed (1939). Results show that fresh figs properly packed and frozen can be held for at least several months in excellent condition for a wide variety of uses. According to W. H. Chandler (1925), some concerns in Los Angeles in 1919 held fresh figs at 280 to $300 \mathrm{~F}$. in 50-gallon barrels with one pound of sugar to two pounds of figs. The qualities desired in a frozen fig product are rich flavor and aroma, tender flesh and skin, well-retained color, inconspicuous seeds, and freedom from internal molds.

Varieties differ as to their value for freezing storage. Tests in Georgia show that Celeste is too small, Brunswick is inclined to split and sour, and Lemon has a thick skin and pithy pulp. Brown Turkey and Ischia White are therefore preferred. Well-matured Brunswick figs are frozen to some extent in Texas. In California, Mission is the most satisfactory because of pronounced flavor, pleasing texture, and deep color. Dottato and Adriatic have an attractive color but are not highly flavored. Lob Injir is unsatisfactory unless the figs are peeled or sliced. E. M. Chace (1940) wrote that peeled, whole Lob Injir figs frozen in 40 per cent syrup by a commercial firm at Fresno in 1937 were an excellent product. The flavor was better than in the unpeeled fruit due to the removal of the cradin. San Piero discolors badly and has a poor flavor.

Figs intended for freezing should be picked at a stage of maturity in which the fruits are soft but not beginning to shrivel. Those sorted out as too ripe for distant shipment are usually about the right maturity for freezing. It is necessary to freeze the fruit within a day after picking, although it may be held somewhat longer at $320 \mathrm{~F}$. with the humidity from 80 to 85 per cent. Mission figs may be peeled and sliced but the whole, unpeeled fruit produces the best and most attractive product. Brunswick figs are peeled by hand or with a solution of lye. In Georgia, hand peeling was found very slow and expensive, an average worker peeling one gallon (6 pounds) of Brown Turkey figs per hour. The amount of peel and stems ran from 33 to 40 per cent by weight of the whole fruit. Peeled figs do not discolor if exposed to the air for an hour or even more but they should be frozen as soon after they are peeled as possible. Since oxidation (according to Woodroof and Bailey, also 
M. A. J oslyn and G. L. Marsh, 1933) is not a problem with frozen figs, the question of containers is simplified. In Georgia, paper-board, tin, aluminum, and glass containers, also aluminum foil, cellophane, and parchment wrapping materials have given good results. Exclusion of air to prevent desiccation is desirable if the product is to be held frozen longer than two months. In California, paraffined paper cups and milk containers and air-tight cans have been used.

Freezing of figs in water results in an inferior product. The use of a

Page 130

\section{Gondit}

130

The Fig

20 per cent syrup results in loss of flavor while a concentration of 50 per cent syrup causes shriveling and is too sweet. Woodroof and Bailey recommend covering figs in the container with a 35 per cent sugar syrup because of the following good results:

The product is made sufficiently sweet; the freezing point of the syrup is similar to that of the figs; the osmotic value of the syrup is similar to that of the juice of the figs; free air is excluded and desiccation is prevented.

In Texas, Reed found that

. . . frozen figs in which approximately 25 to 35 per cent sirup was used gave the best quality pack and about 30 per cent sirup was preferred because of a slightly better balance between the flavor and the sweetness. Under the conditions of these experiments there was some deterioration of quality during storage. This was best retarded by the use of air tight containers.

Figs frozen in a 35 per cent syrup remain frozen at $190 \mathrm{~F}$. or lower. In California, no difference could be detected in the appearance, firmness, or flavor of figs frozen and held at $120 \mathrm{~F}$. and those frozen and held at -200 F. In Georgia, however, nine separate experiments have shown that sub-zero temperatures break down the structure, increase the amount of juice in the defrosted pulp, and destroy the red color in the interior of the figs. Attempts made a decade ago to handle frozen-pack figs on a commercial scale were unsuccessful. The product was excellent but consumer reaction was unfavorable and facilities for distributing the frozen fruit were unsatisfactory or entirely wanting. According to California Fruit News for May 13, 1944, there were 1,380,969 pounds of figs frozen in California in 1943, an amount 
far less than the amount of peaches, apricots, apples, or berries frozen the same year.

Frozen-pack fruits are generally regarded as unsuitable media for the survival of microorganisms. Helen F. Smart (1934), however, found that many species of bacteria, yeasts, and fungi survived after three years* storage at $150 \mathrm{~F}$. In comparison with certain other fruits, figs showed remarkably few microorganisms, the counts averaging about 50 per gram.

deification: deification consists in anointing the eye of the fresh fig with olive oil in order to accelerate its maturity. Theophrastus mentioned it as a practice in Greece in the 3rd Century, B.C., and Pliny told of its use by Roman gardeners. In Italy the process is known as "inolia-zione," in France as "appreter les figues," or erroneously by Juignet (1909) as "caprification," and in English-speaking countries as "oleifica-tion." French and Italian growers use a straw, a hollow reed, or a sliver of wood to apply the olive oil. The operation is performed in the evening shortly before sunset about two weeks before the natural maturity of the fruit. In a day or two the oiled figs begin to increase in size and in eight days they reach full color and maturity, while untreated figs remain green and hard.

Over a century ago experiments on the oiling of figs were reported in southeastern United States by George Clark (1831) and J ohn D. Legare (1831). Clark found that Minorcan residents of St. Augustine were secretly practicing oleification of figs, and his own tests convinced him that the practice would stimulate ripening before the rainy season started.

\section{Page 131}

\section{Chapter XIV 131 Fresh Fig Crop}

Legare read a paper before the Horticultural Society of Charleston, July 13, 1831, entitled, "Results of some experiments to ascertain the effect of oil in hastening the maturity of figs." He found olive oil effective but tallow useless in stimulating maturity of Lemon figs. "Merely touching the aperture of the flower end was of more service than oiling the whole fruit or even the whole flower end." In 1863 and again in 1865, Gasparrini reported his observations on the effects of various agents in promoting the ripening of Italian figs. He found that various oils other than olive oil also stimulated the ripening process, that agents such as vinegar, turpentine, tincture of iodine, and alcohol, showed no stimulating effects, that sulphuric acid in weak concentrations did promote early ripening, that tartaric acid was preferable to oil for the treatment of immature figs, and that sensitiveness existed only in the scales at the eye. Longo (1909) repeated the experiments of Gasparrini and concluded that oleification produced only a traumatic excitation analogous to that secured by twisting a tomato peduncle to bring about early maturity. 
Recent reports on oleification indicate some favorable results and others not so favorable. P. M. Symeonides (1930) found that oiling causes a fig to ripen long before the time of its natural maturity, but that it leaves the oiled skin at the eye hard and dry especially when desiccating winds are blowing. An anonymous writer in the Cyprus Gazette of J uly 13, 1931, says oiling of figs is not recommended and should be avoided, for the practice forces ripening and leaves the product with a low sugar content and poor color. Oleification is practiced in California to a very limited extent by some growers of Mission figs. The general impression is that the gain of a few days in maturity is not worth the time and expense involved and that treated figs are not equal in quality to those allowed to ripen naturally.

Eating Fresh Figs: Fresh figs purchased in markets located long distances from the place of production may be eaten out of hand but are generally prepared and served with cream and sugar. Like many other fresh fruits, they do not equal in flavor and quality similar fruits picked fully ripe from the tree and consumed immediately. Some prefer to peel the skin back from the stem end and then eat the exposed meat and pulp. Others do not bother to remove the skin before eating the fruit.

A method of eating figs without soiling the fingers is as follows: hold fig by the stem end, cut the body of the fig into quarters from the eye downwards, spread the sections back, and with a knife separate the pulp from the skin so the former can be readily eaten. This is well described in verse by $D . H$. Lawrence (1939) :

The proper way to eat a fig, in society,

Is to split it in four, holding it by the stump,

And open it, so that it is a glittering, rosy, moist, honied, heavy-petalted, fourpetalled

flower. Then you throw away the skin Which is just like a four-sepalled calyx, After you have taken off the blossom with your lips. But the vulgar way Is just to put your mouth to the crack, and take out the flesh in one bite.

\section{Page 132}

\section{Chapter XV}

THE DRIED FIG CROP

Production: Production data on dried figs, like those on any other dried fruit, show wide variation. According to Pellicano (1907), the average production of 
dried Dottato figs in three orchards of Gerace Province, Italy, was 863 pounds per acre. Appraisers in the same province estimate production per tree to range from 8 to 26 pounds for young trees and from 26 to 70 pounds for trees in bearing.

Ferrari (1912) gives the average production of dried figs in the Paola region of Italy as 16 pounds per tree and an exceptional yield as 88 pounds. Valley fig orchards near Tizi-Ouzou, Algeria, are estimated to produce 2712 to 3562 pounds of dried figs per acre. Hillside orchards produce much less. An orchard on the Island of Majorca consisting of 1300 trees and occupying 64 acres produced an average of 26 pounds of dried figs per tree over a period of five years. Another orchard averaged 23 pounds for a similar period.

According to Hagan (1929\&), production of mature trees in the Meander Valley, near Smyrna, varies from 20 to 250 pounds of dried figs per tree, the average being 40 to 50 pounds. One orchard thirty-five years old, near Baladjik, produced 100 pounds of dried figs per tree, and another sixty years old produced 114 pounds per tree.

In California, fig trees are considered of producing age the seventh season after planting, although under favorable conditions trees may produce appreciable crops as early as the fourth season in the orchard. Mission and Adriatic orchards produce heavier main crops of dried figs than do Lob Injir (Calimyrna) orchards. In addition, Mission trees usually bear a crop of brebas, which are used either for the fresh fruit market or for drying. M. R. Benedict (1933) estimated the yields of mature fig orchards in the Merced Irrigation District as ranging from 1,50 to 3.00 tons per acre for Dottato (Kadota), 1.00 to 2.50 tons per acre for Adriatic and Mission, and 0.37 to 1.25 tons per acre for Lob Injir. According to E. M. Mrak and J. D. Long (1941), yields of dried figs in San J oaquin Valley orchards vary from 0.5 to 2.5 tons for Dottato and Adriatic, from 1.5 to 3.0 for Mission, and from 0.5 to 2.0 tons for Lob Injir. W. P. Brown (1918) reported that a mature Adriatic orchard of 13 acres near Merced produced 49 tons of dried figs in 1914 and 48 tons in each of the years 1915 and 1916.

Harvesting:- In Italy and in southern Spain, fresh figs are not allowed to dry naturally on the tree but are picked when ripe and dried on trays. Guglielmi (1908) deplored this harvesting of figs before they are completely mature, believing it to be much better to let them partly dry on the tree. E. Mingioli (1904) stated that a perfectly mature fig should have a limber neck, a checked skin, a faded yellow color, a drop of gum at the eye,

\section{Page 133}

Chapter XIV 133 Dried Fig Crop

and should feel soft when touched. At Cosenza, Italy, Dottato figs are dried 
whole, but in Lecce Province the fresh figs are cut in halves and spread on trays with the pulp exposed to the sun. In most countries figs become partially dried on the tree, drop naturally to the ground, and are then picked up for further drying on trays. Hagan thus describes the fig harvest near Smyrna:

After the figs have ripened, wilted, and partly dehydrated on the trees, they drop to the ground. The fruit is picked from the ground once or twice daily by laborers hired for the purpose who live in the orchard. These nomadic people migrate into the fig districts from the grain fields where they have been engaged in the primitive methods employed for gathering and threshing grain. An entire family moves into an orchard, constructs a rude shelter for itself, and takes over the work of gathering, drying, and sacking the fruit.

At Kalamata, Greece, figs are picked up frequently and taken to the drying yard. This consists of a bare piece of ground with raised dirt beds on which reeds or straw are placed. Trays with wooden sides and reed bottoms are also used. In ordinary weather the figs are allowed to dry for three or four days, during which period women sort out the "refusia," or "fabricia."

According to Mauri (1942), figs drying on trees in Algeria acquire a viscous consistency. The skin cracks and shrivels and the whole fruit hangs downward on its stalk. Then the fig is said to be "passerile," or "cured," and in this condition it attains the optimum sugar content. A slight shaking of the branch is sufficient to cause the fruit to drop. Hand picking is not practiced. Drying begins the third week in August and continues until the end of September or later. September showers necessitate some sort of shelter for the drying figs.

In California, as in the Smyrna district, the fig harvest is one which commonly attracts whole families who camp in the vicinity of the orchard. In large orchards harvesting is done by crews of workmen under the supervision of a foreman. Payment is made according to the number of field boxes harvested. In 1945 the rate was 17 cents per 40-pound field box and 25 cents per 50pound box, with a bonus of 5 cents per box paid each picker who stayed to the end of the season.

Before harvest time the orchard ground is cultivated free of weeds and the surface rolled or packed smooth. Theoretically, harvesting of the dropped fruit should be done every day or every other day, but this is seldom practiced on account of labor and expense. The longer the figs are left on the ground the more they are exposed to dust and dirt and to insect infestation.

Figs are picked up two or three times during the harvest season, and in some cases no drying yards or trays are necessary. As soon as possible after harvesting, the picking boxes of orchard-run figs are hauled to a central place and fumigated as described in chapter XX, in order to kill insects and insect eggs that may be present. 
P. F. Nichols and H. M. Reed (1932) reported results of experiments on the drying of figs at various stages of ripeness:

It was found that in order to get good body, heavy, gummy syrup, and good flavor, the figs must be fully ripe and preferably somewhat shrunken when picked. Even un-

\section{Page 134}

\section{Condit 134 The Fig}

dl 'er these conditions the color and shape of the figs did not usually correspond favorably with those of figs allowed to drop naturally from the tree and to dry in the sun.

Sun-Drying:In most countries in which sun-drying is at all practicable, the partially dried figs are spread out one layer deep on some bare surface in order to bring the drying process to completion. This surface is sometimes a bare piece of ground with straw or reeds laid in rows. Sometimes it is the flat roof of a building. More often trays are used because they can be stacked and covered during inclement weather.

According to Eisen, fig drying in Portugal is done on mats woven of esparto grass (Stipa tenacissima). In Italy, trays made of the giant reed (Arundo donax) are used. In the Meander Valley, figs are dried on "serghi" made of reeds cut from Sparta spartifolium. (See E. G. Smyth, 1911, plate 7.) Ravasini (1911, fig. 59) illustrates trays used in Tuscany as having the form of a shield, broad at one end and narrowed to a point at the other. Drying trays are usually elevated 18 inches above the ground in Italy so that air can circulate below. Vallese (1909) deplores the fact that Italian peasants handle dried figs by methods inferior to those used in Roman times; the earlier method, according to Columella, consisted in spreading the figs on trays raised two feet above the ground, and using flat "shepherdl's hurdles" made of sedges or ferns to protect them from dew or occasional rain.

The interior of a properly dried fig should have the consistency of a thick fruit jam or butter, and the skin should have a kid-glove softness and pliability. Occasional stirring or turning the figs during their exposure to the sun and finishing the drying on stacked trays will help to obtain such a product.

In California, wooden drying trays, 3X8 feet, are commonly used. Some growers prefer smaller trays, $3 \times 6$ feet. Trays are usually provided with bottom cleats so that when they are stacked there may be a free circulation of air. Drying yards are on flat, hard ground free of weeds and dust. Sweat boxes about $38^{\wedge} 4 \times 26 \mathrm{H} \times 7^{\wedge}$ inches in size are commonly used for storing and equalizing the moisture in the fruit and also for containers in which to 
deliver to the packing-house. The average weight of a sweat box full of figs is 153 pounds. Smaller boxes known as "baby sweats" are used in some districts and average 87 pounds in weight when full

Drying ratio varies according to the stage of ripeness in which figs are harvested. Guglielmi (1908) picked fresh figs of four varieties, dried them in the sun, and found that the loss of weight ranged from 66 to 70 per cent. In California the drying ratio ranges from 1.30 to 1.0 in figs dropping naturally, and from 3.0 or 3.5 to 1.0 in figs picked ripe but not shrunken.

Dipping and Sulfuring:Mrak and Long (1941) stated: "Adriatic figs are sometimes dipped in water and sulfured before being spread in the drying yard. The dipping cleans the fruit and facilitates the absorption of sulfurous acid. The dipped fruit is sulfured for a period of about 4 hours,

\section{Page 135}

Chapter XV

135

Dried Fig Crop

then spread in the sun for 2 to 4 days, and drying finished in the stack. Kadota figs are sometimes sulfured but the Galimyrna and Mission varieties usually are not."

Sulfur houses should be of tight construction and large enough to hold one or more stacks of trays. Three pounds of sulfur are commonly used per ton of figs. In some states there are regulations restricting the amount of sulfur allowed in dried fruits. Certain large buyers of fig paste specify in their contracts that a product containing appreciable quantities of sulfur ous acid is not acceptable. For these reasons very few California figs are now dipped and sulfured before drying.

Artificial Drying:Artificial drying of figs has long been practiced. In Italy, sundried figs are often subjected to a second drying in an oven. Columella, in the first century after Christ wrote:

Some put up figs, in this very form, in tubs and jars without pitch; and, having daubed the vessels, they toast them either in a small moveable, or great oven, that all the moisture may be dried up the more speedily: after they are dried, they lay them up in a loft; and, when they have occasion to use them, they break the earthen vessel; for otherwise they cannot take out the hardened mass of figs. 
Vallese says that the chief reason for oven-drying is to kill insects and their eggs. Ordinary ovens for baking bread are used. After the oven is heated, the ashes are cleaned out, the temperature is regulated, and the dried figs are spread over the floor of the oven with a wooden shovel. In this second drying, the figs lose 6 to 8 per cent of their previous weight, acquire a pleasing caramel flavor, become golden brown in color, and sometimes dry so hard that it is necessary to humidify them before they can be eaten. According to Portale (1910), these bread ovens are useful substitutes for sundrying only in rainy weather or late in the season.

Robert Williamson (1887) described the sun-drying of figs on his California ranch, then added:

I think the enterprising Galifornian, the intelligent grower, will not much longer waste his precious time with old-time methods, but will find a much speedier and more perfect way to complete success by employing artificial heat. From recent experiments made I am thoroughly convinced that the employment of artificial heat in curing the fig is the dawning of a new and grand era in that great and growing industry in this Golden State.

Mr. Williamson exhibited samples of figs dried in a "Steam Heat Evaporator" for nine hours at a temperature of $1300 \mathrm{~F}$. Eisen (1901) also advocated artificial drying for some localities and stated that "there exists a great number of patented driers in the market, most of which are very good."

In 1903 Massey stated that a portable evaporator was needed for drying figs in a humid climate such as that of North Carolina. The ripe fruit was dipped in strong lye and rinsed in water before being placed in the evaporator. According to Potts (1917), "cook stove" evaporators were used in Texas homes to dry figs and other fruits in case sun-drying was not feasible. E. de Mazieres (1920) described and illustrated both French and American types of evaporators useful in drying figs. Experiments conducted by Reed (1934) in Texas showed that figs allowed to tree-

\section{Page 136}

Condit

136

The Fig

ripen for one or two days longer than the usual hard-ripe stage could be dried in the sun provided the fruit was protected during rains. Dehydration or a combination of dehydration and sun-drying was necessary during adverse weather. 
Nichols and Reed (1932) concluded that dehydration reduces spoilage by insect infestation and microorganisms only when figs are picked from the tree, that the cost of picking and dehydrating appears likely to be offset by increasing returns only when the condition of the figs would otherwise be very bad and the price paid for the dried product is high, and that successful dehydration of cannery-cull Dottato figs is possible but is to be used as a substitute for sun-drying only in bad weather or late season.

E. M. Chace et al. (1941) recommended that figs be dipped for $\% 2$ to y2 minute in boiling lye before dehydration and then rinsed in water and spread about 3 pounds per square foot of tray. When dried at temperatures of 1350 to $1600 \mathrm{~F}$. for 10 to 20 hours, the fig has a dry, glossy skin and a moisture content of 15 to 20 per cent. Recent experience shows that the best product is secured by reducing the temperature and increasing the volume of air passing over the figs.

Despite certain conclusions reported above, interest in dehydration is on the increase. Were it not for post-war restrictions of materials, several large growers of figs would undoubtedly install equipment for the rapid drying of their product. California growers who are now practicing dehydration find that it economizes on trays and boxes, diminishes the amount of infestation and spoilage, and makes fumigation almost or entirely unnecessary.

Sorting and Grading: Sorting of dried figs is done as soon as the fruit comes from the drying yard. According to Hagan, sorting of Smyrna figs "begins on the farm where the orchardist holds back a small percentage of his crop in hopes of a higher market at some future date, perhaps when the major crop movement is over. The fruit reserved is invariably the best in the orchard." Apparently, Turkish figs are delivered mostly as orchard-run fruit and are sorted, as well as graded, in the "hans," as described in chapter IX.

In California, sorting is sometimes done directly from the drying trays. On a large scale, however, it is more economical and satisfactory to use a sorting table, or preferably, a moving belt. The suggestions made by B. J. Howard (1929) were that sorting belts should be 21 inches wide and about 12 feet long, that they should run not faster than 12 feet per minute, and that the figs should not be fed too rapidly at the head of the belt. Such a belt would handle from 600 to 1250 pounds per hour, the amount depending on the size of the fruit. Suitable lighting facilities are very important in sorting figs, whether the work is done on the ranch or in the packinghouse. In presentday practice, some growers use a table having a sorting belt 26 feet long and 36 inches wide and space for seven women sorters on each side. The figs are first fed onto a shaker which removes dirt and trash, and then onto a belt having more than one speed.

When the dried fruit is received by the packer, it is run through a large 
Chapter XV

137

Dried Fig Crop

grader having screens with different-sized perforations. This grader separates the figs into five commercial grades, namely: Standard, Choice, Extra Choice, Fancy, and Extra Fancy. With the Lob Injir, there is a sixth grade, J umbo. Tentative United States standards for grades of dried figs specify varieties, styles of pack, sizes, and grades. Screen sizes for each grade of the three principal varieties are given in table 6.

Table 6.Size Grades of California Dried Figs:

Diameter of screen perforations, in inches Grade Mission Lob Injir Adriatic

Standard $26 / 3230 / 3230 / 32$

Choice $30 / 3234 / 3234 / 32$

Extra Choice $34 / 3238 / 3238 / 32$

Fancy $38 / 3244 / 3242 / 32$

Extra Fancy Over $38 / 32$ Over $44 / 32$ Over $42 / 32$

The Dried Fruit Association of California kept a record of figs graded by packers for the years 1929 to 1935 inclusive. Table 7 shows the total tonnage graded for each variety and the percentage of each grade.

Table 7.Size-grade Record1 of California Dried Figs, 1929-1935, inclusive:

Total tons Percentage of size grades

Variety graded Standard Choice X-Choice Fancy X-Fancy

Lob Injir. 443115164038

Adriatic 87151222302214

Mission 365963533215

i By Dried Fruit Association of California. 
Dried figs graded at Fresno in 1944 showed percentages of size grades similar to those of table 7, with the exception of Lob Injir, which graded 22 per cent Extra Fancy and 18 per cent J umbo.

Storage: Dried figs may be held in storage at temperatures ranging from 320 to $500 \mathrm{~F}$., with relative humidity of 60 to 65 per cent. According to Dean $\mathrm{H}$. Rose et al. (1933), dried fruits usually keep for about a year in cold storage at $320 \mathrm{~F}$., whereas they deteriorate after 4 to 6 months in common storage. W. R. Barger (1941) reported the following results of storage experiments with dried Adriatic figs:

Exposed fruit with 21 to 24 per cent moisture dried out slowly when the relative humidity was 62 per cent and remained nearly constant in weight in an atmosphere of 75 per cent relative humidity. Figs of 10 to 15 per cent moisture are in equilibrium in an atmosphere of about 60 per cent relative humidity. Packed fruit of 25 per cent moisture lost about three per cent weight during a yearl's storage at $500 \mathrm{~F}$. in 60 per cent relative humidity, and gained about three per cent during this time at $320 \mathrm{~F}$. in 85 per cent relative humidity.

During nine months| ' storage at $320 \mathrm{~F}$. with 85 per cent relative humidity, figs near the sides of the package became crusted with sugar, whereas the fruit held in the drier $500 \mathrm{~F}$. room and in the freezer was not sugared at this time and did not become crusted during the entire 13 months of the test.

\section{Page 138}

Condit

138

The Fig

Packers at Fresno commonly store figs in basements or in properly insulated rooms. Rooms with adobe walls and good facilities for night ventilation are used by some growers. Low-grade figs and culls are usually stored in bulk. Handling of the better grades of fruit is facilitated by storage in 50-pound field boxes.

The "sugaring" of dried figs is generally believed to be due to the crystallizing of fruit sugar on the surface. E. E. Baker and E. M. Mrak (1938), however, found that microscopic examinations showed this substance to consist of a mixture of yeast cells and sugar crystals. Cultures of five different kinds of yeasts were isolated from the "sugared" samples, species of Zygosaccharomyces being most common. According to Chemical Abstracts 
(Vol. 22: 3938), a United States Patent was granted in 1928 to Sunland Sales Cooperative Association for the process of reconditioning sugared figs "by placing the unopened packages of fruit in a receptacle and heating at a maintained temperature somewhat below 1000 until the sugar coating has been dissolved and reabsorbed." Proper ventilation in storage rooms helps to prevent development of yeasts and sugar crystals. A thin film of mineral oil prevents "sugaring," but its use is contrary to the present state and federal food regulations. Pure food laws require that only fig oil (practically unobtainable) be used on figs.

Bleaching: A few years ago there was developed a process of bleaching figs with hydrogen peroxide. D. K. Tressler (1942) thus writes :

Calimyrna figs are often bleached by dipping in 17 to 35 volume $\mathrm{H} 2 \mathrm{O} 2$ for 10 to 60 seconds, and then stored for 24 hours or longer before packing. Adriatic figs are more difficult to bleach and peroxide at a strength of 35 to 50 volumes is used. In any case there should be no residue of hydrogen peroxide after a few weeks of storage.

Mission figs were once bleached sufficiently to allow their use in paste, but the natural fig flavor was impaired. Bleaching of dried figs with peroxide has been largely discontinued as other outlets than paste have been found for black figs.

Processing: In southern Portugal, dried figs are thoroughly washed in a tank of cold water and then dipped into a second tank of water containing salt and olive oil. On the Island of Majorca, figs are processed with the same apparatus used for apricot pulp. Each packing-house has a brick firebox and a boiler for heating the water into which the figs are dipped for a couple of minutes.

The processing of dried figs in hot salt water in order to soften and to sterilize the fruit is universally practiced. Eisen recommended dipping the figs into boiling salt water, using \% pound of salt to one gallon of water. Sea water has long been used by fig packers in Smyrna, but there is no reason for preferring it to a solution of common salt. Rixford (1918) believed that the function of salt is to help retain the moisture in the fig as "it is well known that salt absorbs moisture to some extent." Experiments on small-scale processing of figs by A. W. Christie and Mrs. I. J. Condit in 1926 showed that immersion in boiling water for 1 to 3 minutes gives excellent cleansing, rapid gain in weight, and a uniform softening of

\section{Page 139}




\section{Dried Fig Crop}

the skin. The addition of salt ( 4 ounces per gallon of water) gives a slight flavor that is pleasing to some palates; otherwise the salt water appears to be of no advantage and its use may therefore be considered optional.

On a large scale, figs may be thoroughly washed and then processed in live steam for several minutes. Such "softenized" figs packed in foil-wrapped cartons retain their softness for a long period. (See Anon., 1935, 1937.)

Packing: Fancy and Extra Fancy figs are commonly packed whole as pulled figs, split open and flattened out as layer figs, or packed in various other special styles. Some of these specialized packs, such as the Locoum and Macaroni packs of Smyrna, the string figs of Greece, and the Fraga- , style figs of Spain, are described in chapter IX. In the Province of Abruzzi, I taly, dried figs are pressed down into a compact mass; this is then sliced into peculiar shapes, some slices alternating black and white. In southern Portugal, the preparation of fancy packages was common a few years ago, especially for Christmas trade with Brazil. Dried figs of Sicily are sometimes prepared in the form of various fancy figures and designs, such as stars, hearts, and dolls. Straw-colored figs are frequently stuffed with nuts and alternated with black figs. Such packages, however, are of local importance only and are given to patrons and persons of distinction.

In California, figs of the better grades are marketed in bricks and in fancy packs as well as in bulk. The packing of figs in bricks, practically all done by women, is about as follows: each fig is slit down one side with a knife, rolled between the thumb and fingers, and flattened out, with the pulp side down and the stem turned under. The figs are then pressed into a wooden form to make a compact brick. When the form is removed, the brick is wrapped in waxed paper or cellophane and labeled. The bricks range in size from 4 to 16 ounces.

In fancy packs of whole figs, only the very best grades of Lob Injir and Mission figs are, or should be, used. After being processed in hot water or steam, the figs are "pulled", or manipulated between the fingers, until they are soft and pliable, when they can be formed into the shapes desired. Such fancy packages are of numerous shapes, sizes, and materials, and the contents often include nuts, figs, and other dried fruits. A detailed account of "pulling" dried figs into disks or cubes is given by Eisen (1901, p. 193.)

Containers: Containers for dried figs should, as far as possible, preserve the texture of the packed fruit, check the loss of moisture, and prevent insect infestation from the outside. Various containers have been used, such as those of wood, paper, cardboard, glass, tin, straw, and cellophane. Glass and tin containers properly sealed are proof against insects and will preserve their 
contents almost indefinitely, even in hot humid climates; but their cost is high compared to other containers, and their use has not been sufficiently extensive to popularize them in the market. Wooden containers are those most widely used for fancy and bulk packs of 2 to 3 or more pounds in weight. Cardboard cartons are used for smaller packs.

\section{Page 140}

Condit

140

The Fig

Cellophane has come into wide use during recent years. Demands of the armed forces for packages which will withstand rough handling, water, and tropical climates have resulted in new types of containers, some of which will undoubtedly continue in use. One of these containers is a two-pound carton double wrapped with waxed paper. Twelve such cartons are packed into a weather-proof, fiber-board container and the seams sealed with asphalt.

W. B. Parker (1915) showed that ordinary wooden and cardboard cartons were not proof against insect infestation, and recommended the use of sealed cartons similar to those used for cereals. Such sealed packages reduce the tendency of dried figs to lose moisture and to "sugar" on the surface. Figs should be carefully drained after they are processed and should not be packed too hot; otherwise, they may develop mold in the sealed cartons. Mechanical means have been developed for wrapping and sealing dried fruits at a moderate cost.

\section{Page 141}

\section{Chapter XVI}

\section{FIG PRODUCTS}

In the Old World there has developed no extensive industry in fresh fig products because most ripe figs are eaten as soon as they are mature. On the other hand, a considerable percentage of the dried fig crop is used for byproducts. The figs so used are mostly low grade and go into coffee substitutes, wine, and alcohol.

In California, fresh figs are canned on a large scale in tin containers; in Texas, figs are preserved and put up mostly in glass. California dried figs find their greatest outlet in the form of paste destined for bakery products such 
as fig bars and Newtons.

Preserving: The preserving of figs on a commercial scale has been carried on much longer than has the canning of figs. F. S. Earle (1897) wrote that factories at Biloxi and at New Orleans had for several years been putting increasing quantities of preserved figs on the market. Processors paid as high as 4 cents per pound for the fresh figs and could not get enough to fill their orders. Earle described the finished product as partially transparent in a syrup clear and free from sediment. Although Price and White in 1902 knew of only one fig cannery in the state of Texas, Starnes wrote in 1903 that "in Mississippi there already exist extensive canneries putting up presenved figs, ,, and "it is reported a profitable and growing industry."

Methods of preserving figs in Texas are much the same as they were in the early days of the industry. Details of the preserving process are described by Reed in his publication of 1933. Briefly, they are as follows: figs picked firmripe and slightly colored are graded and then peeled by submersion in a boiling 2 per cent soda-lye solution. After being rinsed in cold water, the fruit is cooked in a sugar solution until it becomes translucent. Preserved figs are finished in a syrup of about 440 and breakfast figs in a syrup of 32.50 Balling. After the figs are packed in glass, the containers are exhausted, sealed, and finally sterilized at a high temperature.

Reed (1935) found that peeled, ground figs kept in good condition for at least a year in a solution of 0.4 per cent sulfur dioxide. Preserves made from the stored figs were not so good, however, as those made from fresh fruit.

In California, figs are sometimes preserved by the slow method: the fruit is first blanched in hot water and is then either boiled in dilute syrup or left to stand in the syrup heated to $1850 \mathrm{~F}$. for about 12 hours; on succeeding days the concentration of the syrup is increased and the heatings continued until the product is satisfactorily preserved. A more rapid method is described by Cruess (1938). Firm-ripe figs are parboiled for about ten minutes, cooked in syrup until they become translucent, packed hot in glass

\section{Page 142}

\section{Condit 142 The Fig}

or tin containers, sealed, and pasteurized for about 30 minutes. A still better product is secured by allowing the figs to stand in syrup over night before packing them in jars.

Spiced or pickled figs are a popular product. They are prepared by cooking the fruit in a syrup to which various spices have been added. 
Preserving tests made by Reed of 39 varieties of figs show that several varieties produce a finished product of quality and appearance at least comparable to that of the Brunswick. The Brunswick, however, has shown in Texas a record of hardiness and productivity which any other variety will find it difficult to equal.

Brunswick has been used to some extent in California for preserving, and it makes an excellent product. On account of the low productivity of Brunswick trees, however, their culture has been almost, if not entirely, superseded by that of Dottato (Kadota). No other variety is preserved commercially in California although certain others may be used in home processing. In Louisiana and some other southern states the Celeste is preferred for preserving.

Candying: The candying of figs is largely a continuation of the preserving process. The preface to a discussion on candying figs by Alexander Matthew in 1925 states:

The preservation of fruits and vegetables by impregnating them with sugar or covering them with a coat of sugar crystals is one of the oldest methods of fruit preservation known. Candied fruits have been used as a sweetmeat probably from the time that sugar became a common ingredient in the preparation of our table dishes.

Candying is a lengthy process and requires considerable floor space for open pans and processing kettles. Its primary object is more or less to replace with sugar the cell contents of the fruit. This should be done gradually. After the skin of the fresh figs is pricked with needles to allow rapid penetration of syrup, the process consists of a series of cookings and drainings separated by periods of a day or even a week when the figs are allowed slowly to absorb the cold syrup. The finished product is drained of syrup and dried on wire trays. Matthew (1925) hastened the process by using five concentrations of syrup ranging from 300 to 700 Balling and by making more frequent transfers from one syrup to another.

Candied figs may be marketed after proper drying or they may be coated, or glaced, with a thin syrup, a process which can be carried on successfully only by an experienced operator. A pectin dip, as described by Cruess (1938), is the simplest coating and leaves the surface of the fruit less glossy than a syrup coating. If packed in cardboard boxes, candied figs should be consumed within three months. In vacuum-sealed jars they keep indefinitely.

Canning: In contrast to a 600 to 650 syrup for preserved figs, canned figs are put up in a light syrup testing 300 to 350 Balling. Large-scale canning of fresh figs was initiated by the California Peach and Fig Growers with the erection of a cannery at Figarden, near Fresno, and with the installation of equipment at Turlock. The beginnings of the industry in 
Chapter XVI

143

Fig Products

California are recounted by E. S. Moorhead (1921 and 1924) who had experimented with fig canning at Los Angeles and cooperated with J* C. Forkner at Fresno in 1920. Leslie S. Smith of the Kings County Packing Co., Armona, also pioneered in the canning of figs in 1919 and operated a cannery at Reedley, where 35,000 cases were packed in 1922. F. R. Brann (1923) gives an account of the first seasonl's operation of the Association cannery at Dinuba. The 1923 pack was 30,000 cases of No. 10 cans holding 30 to 40 figs of large size, 50 to 60 of medium, and 60 to 70 of small size. Lob Injir (Calimyrna), the variety canned most extensively for the first few years, is unsurpassed as a canning fig in flavor and richness, but it met with decided sales resistance on account of its softness, seediness, and large size. Dottato has therefore completely superseded Lob Injir for canning purposes. The excellent canning qualities of Dottato are due to the firm texture, attractive yellow color, practical seed-lessness, and medium, uniform size of fruit rather than to its superior flavor.

Canning of figs was discontinued by the Growersl ' Association on account of financial and marketing difficulties. On February 20, 1926, the Board of Directors passed a resolution that the "Association do not further engage in the canning of figs." Facts showed that "the canning of fresh figs required an outlay in grower advances and manufacturing costs of some $\$ 3.00$ for every dollarl's worth of fresh Calimyrna figs canned and a greater amount per pound of Kadotas." Fig canning then passed into the hands of private concerns, which have gradually increased the output to its present status. In 1944 there were packed 908,407 cases of figs in California; this amount was exceeded by cling peaches with 12,279,619 cases, apricots with 7,701,439 cases, and pears with 1,419,306 cases.

Methods of fig canning differ somewhat among the various concerns that handle this fruit. Cruess (1938) recommends grading the figs, blanching in hot water, packing in cans, and cooking in syrup of 550 Balling. The syrup after canning should test about 300 Balling. The addition of 0.5 per cent of citric acid to the syrup improves the flavor of the canned figs.

The Canners League of California has issued the following specifications for figs (8th edition, 1938) :

Fancy: In syrup, 55\% sugar when packed, to cut out a minimum of 32\%. Fruit to be of very fine color, ripe yet not mushy, free from blemishes serious 
for the grade, and uniform in size; woody stems removed.

Choice: In syrup, $45 \%$ sugar when packed, to cut out a minimum of $27 \%$. Fruit same as for Fancy.

Split figs: Quoted as Fancy or Choice, to conform to above specifications except for the fact that the figs are split.

Seconds: Figs that do not conform to the foregoing specifications.

In California the largest proportion of the fig pack is marketed in No. $2 y 2$ size tins, followed closely by those in No. 10 size.

In 1930 R. L. Spangler interviewed retailers and made a report on Market Demand for Canned Figs in the United States. Among other things, he urged standardization of sizes and containers, packing of good quality figs only, and advertising healthfulness of the product. Isabelle S. Thursby (1943) in a bulletin giving instructions for preserving and

\section{Page 144}

\section{Gondii 144 The Fig}

canning figs, concludes: "There is a much greater demand for figs canned in a syrup of medium sugar concentration than for the time-honored fig preserves as prepared in the South. While fig preserves are popular and appeal to most palates, they are extremely sweet and only a small quantity can be eaten at a time."

Canned figs to which were added various amounts of wine were put up in California in 1927, during the prohibition period. "Figs in wine" sold as an intriguing curiosity for a short while but orders were not repeated and the pack was discontinued.

Syrup:Syrup can be prepared from either fresh or dried figs by various methods. Reed obtained a syrup by extracting peeled figs with hot water, filtering, and concentrating under vacuum to 630 Brix. The finished syrup was medium to dark amber in color and practically neutral to the taste. Cruess (1938) made syrup by coarsely chopping dried figs, extracting three times in diffusion battery with boiling water, filtering, and concentrating in a vacuum pan. A thick syrup useful in bakery products is being made at Fresno from standard grades of dried Mission and Adriatic figs.

J am:Comment is sometimes heard that everybody likes fig jam but nobody can prepare it and market it profitably. Fig jam is found on the market but not in the quantity which might be expected. This is apparently due to the 
large number of fruits which are processed cheaply into jam and to the competition which a good fig jam has from inferior brands. Only fresh figs should be used for making jam. Recipes for fig jam are to be found in various standard cook books. The very small seeds and the attractive pulp of Brunswick and Dottato make these varieties especially desirable for a commercial jam product. For home use almost any good fig may be used for jam or for a number of other fresh fruit preparations.

Paste: Approximately 65 per cent of the dried figs of California are ground into fig paste for bakery trade. Paste is made mostly from light-colored figs such as Dottato, Adriatic, and Lob Injir although Mission figs bleached with peroxide are sometimes used. Various blends of varieties are made to produce the quality desired or to regulate the selling price of the finished product. Paste is manufactured about as follows: figs of the proper texture are sliced by machine, then run over a sorting belt where defective fruit is removed. After a thorough washing and a partial drying, they are forced through a two-way grinder. The resulting paste is packed solidly in paperlined boxes weighing 80 pounds when filled.

Coffee:A preparation known as "fig coffee" has long been manufactured in Europe. It is really a coffee substitute or a material used to blend with other substances for coffee. Large tonnages of low-grade and cull figs are shipped in normal times from Mediterranean districts to cities in Austria and other countries for this purpose. Agents in Trieste once held a more or less close monopoly in the fig-coffee business.

According to W. F. Upson, United States Trade Commissioner at

\section{Page 145}

Chapter XVI

145

Fig Products

Vienna (letter dated Oct. 24, 1923), there were imported into Austria in 1922, a total of 11,943 metric tons of dried figs for making coffee substitutes. About one half of the figs came from I taly and most of the remainder were from Greece and Turkey. An Association of manufacturers (Verband Oesterreichischer Kaffeesurrogateerzeuger) constituted a central purchasing agency for most of its members. Prices ranged from 50 to 100 lire per 100 kilograms, f.o.b. Trieste, depending on quality.

Machinery used for the manufacture of fig coffee consists of a roaster and a pulverizer. The roasters are similar to those used in roasting coffee and its 
common substitute chicory. The figs are considered properly roasted when they acquire the color and consistency of roasted coffee beans. After it has cooled, the product is ground and packed in various containers.

Fig coffee was once manufactured in California in considerable quantity. W. F. Toomey (1917), a Fresno fig packer, reported that he was making coffee on a small scale and he hoped that some day this product would take all the refuse figs of the San J oaquin Valley. Mr. Toomey and others, however, found that in the opinion of pure food authorities, roasting did not overcome "defects in the fig." A coffee substitute known as "Fig-co" or "Fic-go" is being made in Los Angeles from dried figs and malt barley. Wilhelm Muller (1925) recommended that in order to meet proper specifications a fig-coffee substitute should have a water solubility of not less than 65 per cent and an ash content, based on the dry substance, of not over 6 per cent.

Alcohol:Immense quantities of low-grade dried figs are used in Mediterranean countries for distillation into alcohol. A black fig grown near Malaga, Spain, is marketed largely in Morocco since the Moors prefer it to other figs for alcohol manufacture. On the island of Majorca cull figs are delivered to the distillery in sacks averaging about 132 pounds in weight. The figs are cooked and fermented by yeast after which the alcohol is distilled off. Accounts of alcohol production from figs are given by A. Vas-seux (1920), J. Benavet (1922), L. A. de Almeida Gois (1938), Cruess (19386), and Cruess and G. L. Marsh (1941).

Cruess concludes that "from a ton of dried figs might be obtained 60 to 70 gallons of alcohol, worth $\$ 15$ to $\$ 17.50$ per ton of fruit. If cost of production is deducted, the gross value of the alcohol is then only about $\$ 6$ to $\$ 7$ per ton of dry fruit. It is worth considerably more for stock feed. I', P. B. Jacobs and H. P. Newton (1938) give the probable commercial yield of 99.5 per cent alcohol as 21 to 26 gallons per ton of fresh figs and 59 to 65 gallons per ton of dried figs. In 1942 when distillers were having difficulty finding raw materials for alcohol production, they paid as much as $\$ 300$ per ton for California cull figs.

Beverages:In ancient Egypt, wines were made from figs, pomegranates, and other fruits. Fig wine was compared to a flame since it burned the throat $(\mathrm{H}$. F. Lutz, 1922). The Kabyles of Barbary drink a very potent brandy made from figs (Alexander Powell, 1926). Wine made from the very sweet figs of Asia Minor is of exceptional quality and

Condit 
The Fig

P. Carles (1891 and 1916) says it is commonly used for adulterating grape wines. The fig wines made in Italy compare with grape wines but certain differences simplify their detection in blended beverages (E. Garino-Canina, 1919). Individuals who know how to regulate fermentation and connoisseurs of wine regard fig wine as an agreeable and potent beverage.

Newtons and Bars:The origin of the term "Fig Newton" is not definitely known. One explanation is that it came from Newton, Massachusetts, a suburb of Boston. Fig Newtons were first offered to the public in a price list issued in 1892 by the Kennedy Biscuit Works of Cambridge-port, Massachusetts. In 1898 this concern was absorbed by the National Biscuit Company of New York City, which has the exclusive right to the use of the term "Fig Newton." An illustrated account of this fig product is given in the National Biscuit Company Magazine for November-December, 1938.

Fig Newtons consist simply of dried fig jam encased in sweetened dough. The machine for making Newtons consists of two compartments, one for jam and one for dough. Inside the machine is a die, a sort of tube within a tube. The inner tube carries jam, the outer tube, dough. From the bottom of the machine come ten, unbaked, endless bars of dough filled with jam. The bars, cut automatically into 40 -inch lengths, are received by pans which are placed in baking ovens for about eight minutes. Revolving circular knives then cut the bars into the short lengths typical of Fig Newtons.

Fig bars are made in immense quantities by bakeries in various parts of the United States. The quality naturally varies with the quality of the dried figs or of the fig paste used in making the jam filler and with the dough used for the casing.

Oil: Fertile fig seeds have an oily, nutty kernel which in some degree imparts a nutty flavor to the pulp. According to G. S. Jamieson and R. S. McKinney (1935), these fertile seeds contain 30.44 per cent oil and 6.3 per cent water. Jamieson (1943) reported that fig oil has a yellow color and a mild but characteristic dried fig taste. Since fertile seeds are found only in caprified figs and are obtained only from certain by-products, it seems there would be no large output of fig-seed oil even if it had outstanding properties.

Other Products: Little need be said about other fig products. The California Fig Growers Association tried unsuccessfully to popularize fig bread, fig meat, nujol-treated figs, Brownies, and other products. For use in bread, dried figs were torn open by machinery, sorted on a belt, cut into small pieces and dusted with flour. While fig bread is good, it has not become popular either with the bakers or with the public. Fig Brownies, described by Condit (1922\&), were prepared from ground figs rolled into small sweetmeats for immediate consumption. Nujol-treated figs, designed as a "natural lubricanttreated laxative,,, ran afoul of pure food regulations and the product had to 
be discontinued. Fig meat consisted of ground figs

\section{Page 147}

Chapter XVI

147

Fig Products

molded into 12-ounce bricks and was intended for use in various ways by the housewife.

Figs, either fresh or canned, make an excellent filling for pies. When used in ice cream, the fig flavor is pronounced and is well liked by most consumers. Candied Dottato figs were marketed in 1925 under the trade name "Figdotas." Texas figs were distributed about the same time and in similar form as "Fignolias." Dried figs have been marketed under such trade names as "Fig and Bran Flakes" and "Fig Nuts" but apparently such products have made no great popular appeal. W. V. Cruess and J. La Moglia (1942) give formulas for including figs in concentrated food bars for general consumption or for army $\mathrm{K}$ ration.

Directions for the preparation and use of figs may be found in cook books. The following have published good recipes: J. C. Forkner (1919\&), Sarah W. Partridge (1920), I sabelle S. Thursby (1932), Carey D. Miller et al. (1936), California Fig Institute (1939).

\section{Page 148}

Chapter XVII

\section{CHEMISTRY AND FOOD VALUE}

Proximate Composition:A mature fresh fig consists of about 84 per cent pulp and 16 per cent skin. Pellicano (1907) reports that fertile seeds in two common dried figs average 1.02 per cent, and those in three Smyrna-type figs, 6.49 per cent of the whole fruit.

Analyses of Fresh Figs:Analyses of fresh figs as reported by various authorities are given in Table 8. The range in water content from 59 to 84 per cent and in sugar content from 12 to 19 per cent can be readily

Table 8.Composition of Fresh Figs1: 
Analyst

Date Water Protein Ash

Crude Reducing

FIBER SUGAR AdD

7o 7070707070

G. E. Colby.......... $189470.00 .720 .36 \ldots 8.00 .06$

to to to to to

84.62 .581 .1620 .90 .24

A. Girard2 ......... 189859.5 .. 0.690 .4113 .01 .54

Atwater and Bryant 190679.11 .50 .80 ... 18.8

R. Paladino ......... 191080.00 .70 .701 .3016 .2

Alice Thompsons .... 1915 ... 1.40 .491 .1610 .80 .14

H. W. Wiley ....... $191779.11 .50 .58 \ldots 15.5$

G. Riviere and

G. Pichard $192678.5 \ldots 0.75 \ldots 15.8 \quad 0.34$

Twining* $192771.7 \ldots 0.641 .5521 .30 .31$

Traub and Fraps .... 192874.81 .30 .600 .9019 .4 C. Chatfield and

L. McLaughlin ... 192878.41 .40 .641 .7016 .20 .17

Ouida B. Abbott..... 193179.01 .50 .60 ... 15.5

J. S. McLester...... 193179.11 .50 .60 ... 18.8

A. L. Stahl ........ $193584.80 .50 .51 \ldots 11.20 .25$

1 All values are calculated as percentages of fresh weight.

2 Average of two analyses. 
3 Average of three analyses.

4 Analyses by Twining Laboratories, Fresno; reported by Condit (1927).

explained by differences in the varieties themselves and by differences in the stage of maturity of the figs when they are harvested. Greater credence might be placed in some of the reported analyses if the figs had been picked fully mature and analyzed immediately rather than picked before complete maturity and shipped a considerable distance before the analyses were made. E. V. Sapozhnikova (1940) reported that the total sugar content varies from 6.0 to 13.50 per cent in the Caucasus varieties of figs and from 8.97 to 15.50 per cent in the Lenkoran and Kirovabad varieties. The sugar content of fresh Dottato (Kadota) figs was found by Condit (1927) to vary from 19 to 24 per cent.

Page 149

Chapter XVII

149

Chemistry

Opinions differ as to the effect of caprification upon the flavor and composition of fresh figs. Condit (1920/) reported the flavor of caprified Adriatic figs to be peculiarly acid, and the flavor of caprified Dottato figs to be sweeter and richer than that of the uncaprified fruit. Analyses of three varieties by Leclerc du Sablon (1908) showed caprified figs to contain an average of 14.5 per cent of sugar, and uncaprified figs, 18.7 per cent. W. V. Cruess and F. W. Albro (analyses reported by Condit 1927, p. 39) found that partially dried Dottato figs contain 35.2 per cent sugar when caprified and 28.4 per cent when uncaprified. Analyses of Dottato figs made by Twining Laboratories, Fresno, also showed a smaller percentage of sugar in uncaprified fruit. M. S. Mohamed and E. M. Mrak (1942) further confirmed this by stating that "caprified figs contained higher percentages of reducing sugars, ash, and protein but a slightly lower percentage of crude fiber."

Colby determined the acid (expressed in terms of sulphuric) content of fresh figs to be lower than that of any other common fruit. The percentage of acid in fresh Dottato figs was found by Condit (1927) to range from 0.10 to 0.44 . E. K. Nelson (1928) reported that diseased Adriatic figs contained more than ten times as much free acetic acid as normal figs but less citric acid. Lob Injir figs contained 0.26 grams per kilo of free acetic acid and 3.5 grams of citric acid besides a small quantity of malic acid. Mohamed and Mrak found that in the development of figs from the green to the ripe stage, pectic acid gradually decreased in content according to variety as follows: Mission, 8.00 
to 1.73 per cent; Adriatic, 7.80 to 1.24 ; Lob Injir, 7.14 to 1.20 ; and Dottato, 5.90 to 1.73 per cent.

The "Relation of Variety and Stage of Development to Composition of Figs" is discussed by Mohamed and Mrak. Seven samples each of Adriatic, Mission, Lob Injir, and Dottato figs were collected at Fresno, representing three stages of immaturity of the first crop fruit, and firm ripe as well as soft ripe figs of both the first and the second crops. Reducing sugars increased slowly during early stages of development and rapidly during later stages. Sucrose was present in relatively small quantities. Lob Injir figs contained low percentages of crude fiber, 7.42 per cent when green and 3.95 per cent when ripe. In comparison, Adriatic figs showed 15.30 per cent when green and 3.80 when ripe. In all samples, crude fiber decreased gradually during the period of fruit development.

As the fig matures and dries, the following changes take place: the moisture content decreases from about 80 to 16 per cent; the sugar content increases from 16 to 60 per cent or more; the individual flowers lose their identity; and the pulp becomes a more or less coherent, syrupy mass enveloping the seeds.

Analyses of Dried Figs:Analyses of dried figs harvested at full maturity should show less variation than analyses of fresh figs. Differences in varieties, climatic conditions in producing districts, and various other factors account for the wide range that, however, does exist in analyses of dried fruit as shown in Table 9.

\section{Page 150}

Condit

150

The Fig

Table 9.Composition of Dried Figs:

Analyst

Date Water Protein Ash

Crude Reducing fiber sugar acid

$\% \% \%$

G. E. Colby.......... 1894 
G. E. Colby......... 1902

W. O. Atwater and

C. D. Woods ....... 1896

A. Pellicano ....... 1907

G. Guglielmi ........ 1908

H. W. Wiley ....... 1917

Twining3

Lob Injir .......... 1922

Adriatic .......... 1922

Mission ........... 1922

J. S. McLester........ 1931

N. Mauri........... 1942

23.04.282.0210.14160.050.42

23.64.181.146.7963.43...

22.55.102.4070.02

$20.7 \ldots 48.20 \ldots$

20.45.182.256.8356.51

28.73.582.756.1951.430.71

15.73.392.105.8062.840.42

16.83.282.226.9564.340.43

16.33.301.944.5064.290.43

18.84.302.40...74.202...

17.53.502.5060.00... 
i Average of two analyses; given as crude fiber, $\mathrm{N}$-free extract, and fat. 2 Given as carbohydrates.

8 Unpublished analyses made by Twining Laboratory, Fresno, of 19 samples of Lob Injir, 21 of Adriatic, and 8 of Mission dried figs.

Colby (1902) gives the following analysis of seeds of a black Smyrna-type fig grown in California: water 6.0 per cent, protein 14.0, carbohydrates 13.5, fat 34.4, fiber 30.4, ash 1.7.

Analyses of the ash of figs are shown in Table 10.

Table 10.Ash Analyses of Figs:

Twin-J. S. McLester3

G.E.ing Lab.,F.1931F. WOHLT-

Colby1FresnoCZAPEK2Dried FreshMANN

Composition189419161925figs figs1892

$\% \% \% \%$ J*

$0.682 \ldots . .2 .86 \ldots$

55.8343 .7032 .230 .9640 .30328 .4

2.384.2019.630.046 0.01226.3

10.9011.7224.570.162 0.05318.9

$5.603 .60 \ldots 0.0710 .0229 .2$

Peroxide of iron...2.190.50...0.0031.5

Oxide of manganese $0.21 \ldots \ldots \ldots \ldots \ldots$

Phosphoric acid ..12.7610.8013.470.116 0.0361.3

Sulphuric acid----3.90....7.120.056 0.0106.7

$4.3014 .842 .34 \ldots \ldots . . .5 .9$

2.083.00.830.043 0.0142.7 
i Dried fruit, average of three analyses.

2 Fresh fruit.

3 Percentage of whole fruit.

Enzymes: Various studies of the sap of the fig tree have shown that it contains an enzyme capable of dissolving proteins. This enzyme is now known as "ficin," or "cradein," and is peptic in action. A comparative study of the latex of the fig and that of the paper mulberry by C. Gerber

\section{Page 151}

\section{Chapter XVII 151 Chemistry}

(1912a, b) shows that the starch-splitting properties of fig latex are oneeighth as strong as those of the latex of the mulberry, but that its power to coagulate milk is one hundred times as great as that of the mulberry. Gerber and J. Salkind (1913) determined that subcutaneous injections of fig latex into a pigeon produced fever, local congestion, lesions of a necrotic character, convulsions, and finally death in a state of coma. N. T. Deleanu (1916) found that the peptolytic enzyme from fig latex is identical with that from papaya.

According to R. Chodat and E. Rouge (1906), the "labferment" of Ficus carica, which they called "sycochymase," is without doubt the oldest coagulating enzyme known, having been used in ancient Greece for the making of cheese. On the Island of Majorca, the peasants prepare curdled milk by heating the milk and then stirring it with split fig branches; this causes very rapid coagulation. Diana Bruschi (1907) tested the coagulating power of various parts of the fig tree, such as buds, branches, fruit, and foliage, at five periods of vegetation from March 21 to J uly 29. On the latest date, when mature leaves were used, the most rapid coagulation was at a temperature of $940 \mathrm{C}$.

A. Walti, in 1938, patented a process for producing crystalline ficin. W. V. Cruess and W. Y. Fong (1926) reported that Mission figs gave a very strong positive test for both catalase and peroxidase. The presence of catalase was indicated by the evolution of $\mathrm{O} 2$ upon addition of $\mathrm{H} 2 \mathrm{O} 2$. Fong and Cruess (1929) found that the temperature required for inac-tivation of peroxidase varied with the $\mathrm{pH}$. The amylase and other enzymes of the fig have been treated in detail by Anne Wood (1942).

In 1936 Kunio Okahara extracted from leaves of Ficus carica a chemical substance which he named "ficusin." This substance was precipitated as colorless, needle-like crystals having the empirical formula of CnH603. It had 
a bitter taste and a faint odor.

Laxative Properties: Both fresh and dried figs have long been regarded as laxative foods. Athenaeus in The Deipnosophists gave the physician Daphnus as authority for the belief that thoroughly ripe figs are more easily digested than other fruits. Furthermore, figs were said to be mucilaginous, sweet, slightly alkaline, and to cause copious bowel movements. Modern physicians and dietitians generally agree as to the laxative effect of figs but disagree to some extent on the nature or cause of this property. According to L. E. Sayre (1906), the laxative action of dried figs is mainly due to the indigestible seeds and fiber. C. F. Langworthy (1913) expresses the belief that the laxative effect of such fruits as the prune and the fig can be ascribed in part to the bulk and in part to the acids and salts they contain. Cruess (1938) found that fig syrup apparently has no laxative effect.

According to Henry $\mathrm{H}$. Rusby (1923), the fig is listed in the Pharmacopoeia because of its use in the "Confectio Senna.,, "Syrup of Figs," which is sold as a laxative, contains very little fig juice. It owes its laxative properties to senna and not to figs. Another preparation, known as "Ex-lax/'

\section{Page 152}

\section{Gondit}

152

The Fig

is advertised as "the fig laxative" and is said to be made of choice figs combined with a medicinal ingredient.

Agnes F. Morgan (1932) thus sums up the matter with respect to figs:

One of the most distinctive features of the food effect of figs is the gentle stimulation which they provide for the intestine. Whether this laxative effect is due to the presence of the numerous tiny seeds and fine fiber of the fruit or to a specific perhaps soluble constituent of the juice has not been definitely established. It is probable that both factors are involved. . . . Certainly no other palatable article of food, with the possible exception of prunes, can be said to offer a natural aperient action, much needed in the modern refined and concentrated diet.

Medicinal Properties:For several millenia medicinal properties have been attributed to the fig, both fresh and dried. According to C. H. LaWall (1927), the fig is included among the components of a tonic or drug described on an Egyptian papyrus of 1552 B. C. The modern physician might not fully agree 
with the statement of Andrew Borde (1547) that "fygges doth nowrysshe more than any other frute. . . . They do dense the brest and the lunges, and they do open the opylacyons of the lyues and the splene. . . . And also they doth provoke a man to sweate; wherefore they doth ingender lyce." A contemporary of Borde, Aulus C. Celsus (1549), believed that flatulence of the stomach was produced by eating figs, especially if they were green. He advised men, after exercising, to eat 3 ounces of very juicy figs cooked over charcoal.

Pierre J . Garidel (1715) maintained that certain varieties of figs were superior to others in food and medicinal value. While he stated that ancient physicians exaggerated the value of dried figs in medicine, Garidel himself prescribed several fig concoctions for such ailments as inflammation of bronchial tubes, measles, and smallpox. Pierre Chomel (1782) mentioned some of the fig preparations listed by Garidel and stated that they alleviated coughs and colds. He recommended that for hoarseness and loss of voice dried figs be macerated in brandy. Aaron Burr (1838) wrote in his diary that for a severely swollen jaw, "I apply roasted figs as poor Barton used to do." He further stated that the next day, after a discharge of pus, "the swelling is nearly gone, and no pain." The "universal antidote" compounded by Mithridates for poisons and plagues contained figs as one of three ingredients. \{See Theodore Reinach, 1890.)

The use of figs as medicine is mentioned in the Bible. For example, dried figs were used as a very effectual poultice upon boils. According to $\mathrm{H}$. J. Van Lennep (1875), the boil of Hezekiah, doubtless of a malignant character, was not cured by the "lump of figs, a remedy well known to the kingl's physicians; but the prophet ordered it to be treated as a common boil with the assurance it would prove as harmless." \{See II Kings 20:7.)

Modern works on medicine seldom include the fig in lists of remedies or drugs. Rusby (1923) states that it can scarcely be considered a medicinal substance even though it is somewhat laxative.

\section{Page 153}

Chapter XVII

153

Chemistry

Food Value:In most countries bordering the Mediterranean Sea, the fig both fresh and dried is regarded as the poor manl's fruit and is eaten in immense quantities. It is estimated that an average family of Kabyles in Algeria consumes 1500 pounds of figs annually. A family of five in Lecce Province, 
Italy, uses from 300 to 500 pounds of dried figs each year; in contrast, a person in the United States consumes less than one pound of dried figs per year.

The men of ancient Sparta were required to dine in a common hall, and each was obliged to provide monthly one bushel of flour, 8 measures of wine, 5 pounds of cheese, and $2 \mathrm{y} 2$ pounds of figs.

\section{Pliny wrote:}

Figs are restorative, and the best food that can be taken by those who are brought low by long sickness, and are on the way to recovery. They increase the strength of young people, preserve the elderly in better health, and make them look younger, and with fewer wrinkles. They are so nutritive as to cause corpulency and strength: for this cause, professed wrestlers and champions were in times past fed with figs. (See Henry Phillips, 1831.)

According to Louis A. Hanoteau and A. Letourneux (1873), the eating of fresh figs produces among the Kabyles of Algeria a nervous excitement resembling intoxication. During the fig season the people are quarrelsome and engage frequently in brawls. The idea that the Kabyles are apparently more excitable during the fig harvest than at other times gains confirmation from the popular saying: "Drunk as a Kabyle gorged with figs."

Considerable work has been done in California in recent years on the nutritive value of figs. Agnes F. Morgan (1926) and her associates compared the value of milk, orange, and figs as supplementary lunches for children. All of the 47 children received their usual but controlled diet, supplemented in one group by $y 2$ pint of milk, in another by 1 medium orange, and in another by 4 pulled figs. The average gain as judged by three different standards was highest for the orange group, followed in decreasing order by the fig, the milk, and the control groups. The results indicate the order of supplementary value of these foods for the usual home diets of children.

In 1932 L. G. Saywell reported the effect of figs and raisins on urinary acidity. The increase of $\mathrm{pH}$ of the urine resulting from the daily ingestion of 330 grams of figs ranged from 0.9 to 1.1 units, or a slightly greater change than that produced by an equivalent weight of raisins. Saywell concluded that "for considerable quantities of natural grape and fig products the body is capable of completely oxidizing the organic acids."

Both M. E. J affa (1929) and Agnes F. Morgan (1932) have treated the "Unusual Nutritive Value" of figs in considerable detail. The latter states that dried figs have a considerably higher excess alkalinity than other alkaline foods. Their total mineral content is two to four times as great as that of most fresh foods, and only cheese and one or two of the nuts have a higher calcium content. Dried figs are rich in iron and also in copper, surpassing in these respects nearly all fresh fruits and vegetables and even most of the 
other dried fruits. Dried fruits owe their food value

\section{Page 154}

Condit

154

The Fig

chiefly to their mineral content. Morgan (1941) has worked out the following nutritive index for the fruits specified: figs 11 , apples 9 , raisins 8 , dates 6 , pears 6.

Vitamins:Vitamins of figs have received the attention of various investigators. Anna Field (1931) found that both Lob Injir and Dottato contain slight amounts of vitamin A. In 1931 also, F. V. Hahn reported that dried figs have less than 16 units of vitamin C, as compared with 200 units in orange juice and 100 units in rose hips.

In 1932 and in 1935, Morgan and her associates reported the following facts regarding the vitamin content of figs: the vitamin $\mathrm{C}$, or antiscorbutic property, of fresh Lob Injir and Dottato figs is about equivalent to that of fresh grapes and about one-half that of fresh peaches or prunes. Fresh Mission figs seem to be less well endowed with this vitamin. Very little of the vitamin $C$ is retained in any of the dried figs, but vitamin $A$ is present in fair amount in all these three kinds. Dried figs contain "from 1 to 1 y2 Sherman units of vitamin $\mathrm{G}$ in $3 \mathrm{gm}$. a value not affected measurably by sulfuring or other variations in the drying procedure." Fresh Dottato and Adriatic figs contain about equal amounts of vitamin B, 25 International or 35 Sherman units per 100 grams.

Carey D. Miller et al. (1936) found that the Brown Turkey fig grown in Hawaii is a fair source of vitamins A, B, and $G$ and a poor source of vitamin C. Esther P. Daniel (1939) reported figs as a good source of thiamin (vitamin Bi) and a fair source of riboflavin (vitamin G). E. M. Mrak (1941) gives the following summary regarding the retention of vitamins by dried figs:

Figs contain some vitamin $C$ in the fresh state but none when dried even though they may be sulfured. A possible explanation for this is that figs normally undergo a partial drying on the trees before harvesting and vitamin $C$ destruction may occur during this period. Sulfuring favors the preservation of vitamin A in all but the Adriatic variety and the destruction of $\mathrm{Bi}$ in all varieties. It has no effect on riboflavin. Vitamin retention was greater when the fruit was dehydrated than when sun-dried. 
Figs for Stock Food:Dried figs, especially those unsuitable for human consumption, have long been used for stock food. Aristotle says that figs were used in ancient Greece for fattening hogs. Growers on the island of Majorca believe that figs produce fat pork but not good lean meat and that acorns produce good meat with less fat. In southern Spain, poor grades of black figs are used for mule and cattle feed. One arroba ( 25 pounds) of figs is considered equal to one measure of oats; therefore the price of figs for cattle feed depends upon the price of oats. In California, figs are relished by coyotes, and in recent years the owners of fox farms have fed large quantities of low grade figs to their foxes.

M. E. J affa and L. Anderson (1901) have considered the value of fresh and dried fruits for stock food. They show that eight pounds of fresh figs, which have a high protein content, equal one pound of wheat. The conclusion is reached that pigs will increase in weight more rapidly from a ration of dried figs than from one of grain since the pigs will consume about

\section{Page 155}

\section{Chapter XVII}

\section{5}

\section{Chemistry}

three times the quantity of figs that they will of grain. D. T. Fowler (1909) tells of a ten-year-old Mission fig orchard in Kern County, California, which paid nearly $\$ 100.00$ per acre in one year in its production of fruit for hog feed. J. Benavet (1922) shows that the high food value of dried figs is due to the high sugar and protein content; even after the figs have been fermented for alcohol, the residue of figs makes a good stock food.

The practical question is often asked: "How do figs compare with other stock food in money value?" (See Pacific Rural Press, October 15 and 29, 1927; October 21, 1933; March 6 and December 18, 1937.) The general opinion is that dried figs are a good food for stock if fed with other materials. One grower used the following mixture for each 100 pounds of gain in weight of hogs: 123.81 pounds of skim milk, 94.05 pounds of dried figs, 97.02 pounds of barley and corn in equal proportions. If barley is worth $\$ 25.00$ a ton, dried figs would have a comparable value of $\$ 21.60$ as stock food.

Fig leaves are also used as fodder for cattle. At Tizi-Ouzou and other places in Algeria, fig leaves are commonly harvested just before their natural drop and used to feed stock. The same is true in fig districts of Sicily. On the Island of Majorca, the fallen leaves serve as sheep pasture. In southern Portugal, boys and girls pick fig leaves from the trees, rake them into piles, 
and take them to store houses, where they are used to feed domestic animals.

\section{Page 156}

\section{Chapter XVIII}

\section{ECONOMICS AND MARKETING}

Statistics: Some figures on the production of figs in various countries have been given in chapters IX and X. We may assume that the acreage of bearing fig trees has not been greatly reduced during the war period and that production will soon approximate or even exceed that of pre-war years. This assumption is corroborated by recent reports from Turkey that the preliminary forecast of dried fig production for 1945 is 28,600 short tons, which is 8 per cent less than the five-year (1939-1943) average of 31,200 tons and 14 per cent less than the ten-year (1934-1943) average of 33,500 tons.

From statistics recently compiled by S. W. Shear, Giannini Foundation of Agricultural Economics, University of California, Berkeley, for the period 1934 to 1938, it appears that the average annual dried fig production of the five countries, Turkey, Greece, Italy, Algeria, and Portugal was 166,180 short tons. Production figures for Spain were not included. Germany was the largest importer, averaging 20,000 tons annually, over half of this amount coming from Turkey. France and Austria each imported 14,000 tons, the former getting over half the total tonnage from Algeria. The United Kingdom imported 6400 tons, mostly from Turkey. The following countries each imported over 1000 tons of figs: Yugoslavia, Czechoslovakia, Poland, Belgium, Netherlands, Denmark, and Sweden. The United States imports for the period averaged 2800 tons, half coming from Turkey, 1000 tons from Greece, and 340 tons from Italy. W. R. Schreiber (1945a) states: "The preliminary estimate of dried fig production during 1944 in the leading commercial producing countries is 198,100 short tons, compared with 176,600 tons in 1943 and 178,400 tons in 1942."

In 1929 S. W. Shear published a report on the economic status of the fig industry. Among other things, he emphasized the fact that per capita consumption of figs in the United States is low; that among dried fruits used, figs rank third, being exceeded only by raisins and prunes; that the average national consumption of dried figs for the five years 1923 to 1927 of 27,800 tons was almost double that for the period 1909 to 1913; and that there was a small but increasing proportion of the fig crop used in fresh and canned form. In 1914 the fig acreage in California was 5857 acres; by 1927 it had increased to 42,562 , or 626 per cent, a far greater increase than that of any other fruit crop. Since 1927 the fig acreage has decreased until in 1945 there were 33,330 bearing and 2180 non-bearing acres. 
The 1940 census of the United States showed Fresno and Merced counties in California to be the leading fig counties, the first having 856,925

\section{Page 157}

\section{Chapter XVIII 157 Economics}

bearing trees, and the second, 431,591 trees. In 1930 Brazoria County, Texas, ranked third and Galveston County fourth. By 1940 the position of these two counties was reversed, Galveston having 79,777 and Brazoria 43,148 trees. San J oaquin County, California, had 143,343 fig trees of bearing age in 1940. In 1944 Fresno County reported 17,092 and Merced County 8631 bearing acres of fig trees.

In $1920 \mathrm{~J}$. C. Forkner emphasized the fact that the California fig industry was then only 5 per cent that of the orange, $6 \%$ per cent that of the raisin, 10 per cent that of the prune, and 25 per cent that of the peach, the apricot, and the lemon industries, respectively. In the ensuing twenty-five years the dried fig has caught up with, and even surpassed, some of its competitors and now occupies third place among California dried fruits. According to the Statistical Number of the California Fruit News, July 14, 1945, the average production in tons of seven dried fruits of California for the seven-year period, 1938-1944 was: raisins, 267,853 tons; prunes, 173,228; peaches, 21,652; apricots, 20,826; figs, 20,435; apples, 7775 ; pears, 4412 tons. The California Fig Institute reports, however, that the average production of California dried figs for the above period was 31,970 tons and that even merchantable figs averaged 24,500 tons.

Prices: Wholesale prices to the trade on dried California white figs packed in 50-pound boxes, ranged from 4 cents per pound in 1897 to 17 cents in 1918. Opening prices quoted on 1924 crop dried figs by the California Peach and Fig Growers were, for standard Adriatic in 25-pound boxes, 5 cents, and for extra fancy, $9 \wedge 4$ cents per pound. Comparative prices for Calimyrna were $6 y 2$ cents for standard and 13 cents for extra fancy.

The demand for dried fruits during the war years and the cessation of fig imports from Mediterranean countries are reflected in the comparatively high prices received by growers during recent years. G. K. York (1941) gives, in tabular form, base prices to growers for dried figs for the seasons 1937 to 1941. For Mission figs, prices ranged from 2J/2 to S]/2 cents, for Kadota, 3 to AJ $/ 2$ cents, for Adriatic, 4 to 9 cents, and for Calimyrna, 5 to IIiyz cents per pound.

In 1945 York stated: "Packer and trade ceilings were fixed on the basis of I'recommendedl' grower prices which were the same as in 1944 and 1943, 
namely $\$ 200$ per ton for 85 test Black Missions, $\$ 230$ for 85 test natural Kadotas, $\$ 240$ for 90 test, tray dried Kadotas, $\$ 250$ for 80 test Adriatics and $\$ 380$ per ton for 75 test Calimyrnas. All figs were free for sale into civilian channels. There was a tendency for packers to advance bids to close deals and the market closed well above opening.,,

In September 1945, California growers were receiving 12 to 13 cents a pound for good Mission figs, 15 to 16 cents for good Adriatics, and 20 to 24 cents for good Calimyrnas.

Inspection: The rules and regulations for enforcement of the Federal Food and Drugs Act state that an article shall be deemed to be adulterated "if it consists in whole or in part of a filthy, decomposed or putrid animal

\section{Page 158}

Condit

158

The Fig

or vegetable substance." \{See H. C. Wallace, 1922.) Previous to 1909 there were no pure food restrictions upon the importation or sale of dried figs in the markets of the United States. Inspection of imported figs was started in 1909 as a result of a report received from the United States

1 DRIED FRUIT ASSOCI ATIONDJ F^i. INSPECTION No.

1 OF CALIFORNIA " I | ADVISORY BOARD CERT. JV+.

1

1 FIG INSPECTORI'S WORK SHEET

1! NUMBER OF H PACKAGES1 STYLE OF J PACKAGEVAMETT AND CBADECROPSHI PPING MAUL

|j Unit Number J

II Insect 1 1] J nfbsthd

jj Moldy (and/ II or Smutty)

|| Souk (anzj/or || Internal Rot) 
|l Filthy

II WO\&THLBSS | 9 Total---------------7-----J

|| Date

Signed.

1] Form 281 nspector 1

Fig. 26. Blank form used by fig inspectors in California.

Consul in Smyrna that sanitary conditions were not good. As a result of conferences between various government officials and importers, it was agreed that dried figs showing more than $33 \%$ per cent infestation or filth could not be received and offered for sale.

On August 15, 1925, the Bureau of Chemistry of the United States Department of Agriculture sent a notice to dealers and importers of figs that every shipment containing an appreciable amount of filthy figs would be denied entry and would have to be exported or destroyed. As a result

\section{Page 159}

\section{Chapter XVIII 159 Economics}

of the season ' 's inspection, the tolerance on filthy figs was reduced from ZZYz per cent to 20 per cent. Again, on March 10, 1927, instructions were sent by the Bureau of Chemistry to "bring action against any shipments of figs containing in excess of a total of 10 per cent of figs showing distinct evidence of mold, fermentation, larvae, worm or insect action."

The extent of federal fig inspection and its results are indicated by the report of W. R. M. Wharton (1930) that "last year more than 11,500,000 pounds of figs were refused entry into this country. This amount represented 50 per cent of all such products shipped to the United States.,,

Federal inspection of figs applies not only to imported figs but also to domestic figs entering into interstate commerce. The result has been to stimulate investigations in California on causes and prevention of fig-spoilage diseases, on prevention of insect infestation in the orchard, drying yard, and packing house, and on methods of fumigation. Certain interests always show resentment to any restrictions upon the operation of free enterprise. In general, however, such restrictions have benefited the fig industry as a whole even though they may have caused growers and packers temporary financial losses. 
Harold Hyde, Director of the California Fig Institute, stated in his Annual Report, January 30, 1945, that the need for maintenance of high standards of quality for California dried figs is obvious. This is partly due to the concern of food and drug authorities about the quality of shipments of packed fruit moving into the trade and about the conditions under which food is produced, stored, and packed. "Industryl's future success in the field of postwar competition will depend on growers|' ability to produce the maximum amount of good figs .... the minimum amount of defective fruit and culls." (Hyde, 1945.)

In a letter dated December 28, 1945, Hyde described the testing procedure for California figs to be as follows :

Under the Dried Fig Marketing Program (the Grower Prorate Program) sampling and inspection of figs at the time of delivery are required. Briefly, the regulations fix tolerances on Calimyrnas, Adriatics, and Kado-tas at 30\% for all defects of which not more than $15 \%$ shall consist of infestation. In the case of Black Missions the over-all tolerance is $20 \%$ of which not more than $15 \%$ shall be infestation. Only lots which upon inspection come within these tolerances, qualify for delivery as marketable figs. Those which fail to meet these tolerances are classified as substandard, and within certain limits qualify for retest or release for resorting purposes, or, if not, must be diverted to the Diversion Pool. The sampling procedure involves the designation at random of at least $10 \%$ of the containers which are dumped through an automatic sampling device by which means a test sample is obtained. These test samples are then turned over to the Dried Fruit Association of California, which is the authorized inspection agency, and, depending upon the size of the delivery, from 100 to 600 figs are counted out, cut and examined for defects. The average percentage of defects as shown by this inspection determines the qualification of the fruit for marketing and the percentage of sound passable figs is used as a basis for determining the price to be paid to the grower.

\section{Page 160}

\section{Gondit}

160

The Fig

The outgoing inspection, sampling and testing procedure under the Marketing Order for Dried Figs and Dried Fig Products (the Packer Program), is somewhat different due to the fact that it involves a wide variety of styles and types of packs. In this case it is required that any figs being prepared for market must be sampled and inspected in units of not to exceed 1500 pounds each. Only units of such figs, which upon sampling and inspection are 
found to contain not more than a total of $10 \%$ of defects, can be further processed, such as grinding into paste, and shipped into the trade. The difference between this sampling and testing procedure and that described above in the case of grower deliveries is that there is always a fixed quantity to be inspected and a fixed number of figs or pieces of figs to be examined; whereas, in the grower deliveries the number of figs to be examined varies with the size of the load. Under the packer program rejected units ( 1500 pounds each) may be reworked under the supervision of the inspection agency, and, in any event, must again be submitted for sampling and inspection.

Tariff:Tariffs on food products are apparently not new. According to Tenney Frank (1933-1940), there was a tax on figs, dates, and olives in ancient Egypt; and in North Africa during the Roman occupation the tax on 100 pounds of figs valued at 80 sesterces, or $\$ 4.00$, was J 4 denarius, or about 10 cents. David MacPherson (1805) stated:

It being found exceedingly difficult to adjust the value of the damage, sometimes sustained by figs in their importation, to the mutual satisfaction of the importers and the revenue officers, the former allowance of discount for damages was now abolished, and instead the duty on all figs was lowered from 10/12 per cwt. in British vessels and 13/4 in foreign ones to 10 shillings and 10/6 with a drawback of 9/2 on exportation. A.D. 1793.

According to Parliamentary Papers of Great Britain (see Anon., 1898), an act of 1823-24 specified a tariff of "1 \#. 1 s. 6 d." per cwt. on imported

Table 11.United States Import Duties on Figs, 1790-1909:

Act ofRate of duty

August 10, 179010 percent ad valorem

March 7, 18042 cents per pound

April 27, 18163 cents per pound

May 22, 18243 cents per pound

July 14, 1832Exempted from duty (free)

August 30, 18422 cents per pound

July 30, 184640 percent ad valorem

March 2, 18613 cents per pound 
August 5, 18615 cents per pound

June $6,18722 y 2$ cents per pound

March 3, 18832 cents per pound

October 1, 18902y2 cents per pound

August 27, 1894V/2 cents per pound

July 24,18972 cents per pound

August 5, 19092^ cents per pound

Source: Tariff Acts, 1789 to 1909 (House of Representatives, 61st Congress, 2nd Session, Document No. 671; Washington, Government Printing Office, 1909).

\section{Page 161}

Chapter XVIII

161

Economics

figs with a drawback of $19 \mathrm{~s}$. if the figs were re-exported. On August 15, 1834, the fig tariff was reduced to $15 \mathrm{~s}$. per cwt, but beginning in 1840 an additional 5 per cent was levied on fig imports. This tariff remained in force until March 7, 1860, when it was reduced to $7 \mathrm{~s}$. per cwt. Apparently there have been no changes since that time.

A tabulation of the tariff rates on United States imports of dried figs from 1790 to 1909 has been furnished by Walter Fischer, Senior Commodity Specialist, United States Tariff Commission. (See Table 11.) He writes that a great many changes were made early in tariff history in some of which the rate on figs was affected by a regrouping of commodities. In other cases special privileges were granted goods, including figs, transported on American vessels.

In the Tariff Acts of 1913 and 1922 the import duty on figs fresh, dried, or in brine was set at 2 cents per pound. The Act of J une 17, 1930, raised the duty to 5 cents per pound. In the trade agreement with Turkey effective May 5, 1939, it was specified that the import duty should be 3 cents on figs valued at 7 cents or more per pound. On dried figs valued at less than 7 cents the rate remains as before, namely, 5 cents per pound. In some cases the rate is 
given as per cent ad valorem. Since 1939 the ad valorem equivalent for figs valued at less than 7 cents per pound is given as 110 per cent, and for figs valued at 7 cents or more per pound, as 30 per cent. Nearly all imports of figs into the United States are dried figs. There have been virtually no imports of fig paste since 1930.

Marketing:The packing and marketing of dried figs is, in most i countries, the concern of independent companies. In Izmir, Turkey, there are at least ten firms which pack and export dried figs. In Fresno, California, there are six plants which pack nothing but figs, and three others which handle dried figs along with raisins and other dried fruits. Some companies make a specialty of fancy packs, particularly for the holiday trade.

Cooperative marketing of dried figs has been tried both in Turkey and in California. In the Meander Valley, a Cooperative Fruit Growers Association was organized in 1914 to handle figs grown by its members. During the first season it handled 2000 tons of dried figs. The Cooperative was reorganized in 1923, and after it was given certain privileges and immunities by the government, it was entrusted with the sale of Sultanas, olive oil, cotton, and a few other commodities in addition to figs. It now handles 70 per cent of the fig crop.

Cooperative marketing of California figs has had a long and checkered career. The California Fig Growers was organized following the meeting of the second annual Fig Institute in J anuary, 1918. Some of the stated purposes of the organization were: to aid in the establishment of a standard pack of each variety of dried figs, to secure to the growers each season as far as practicable a uniform price for a uniform quality of product, and to assist members in marketing their figs or fig products by furnishing information as to prices, markets, and reliable dealers.

During the 1918 and 1919 seasons, fig prices were good, and growers

\section{Page 162}

\section{Gondit}

162

The Fig

had no difficulty marketing their crops. In May, 1920, however, J. F. Niswander announced: "Six months ago figs were commanding from fifteen to twenty cents per pound. Today, as far as we are informed, there are no buyers for figs at any price $/{ }^{\prime}$ 'A merger was thereupon arranged between the Fig Growers and the Peach Growers, the new organization becoming the 
California Peach and Fig Growers. An account of this new Association and of the signing of contracts by growers may be found in the Associated Grower, J une, 1920. A copy of the fig contract is given on page 8 of the Grower for May, 1920. The contract specified that for each of the years 1921 to 1924 the Association would pay the grower, on delivery of his dried figs, 4 cents for Calimyrnas, 3 cents for Kadotas and Adriatics, and 2.5 cents for Missions.

Marketing results for dried figs during the first four years of operation by the new Association were not satisfactory, and in 1925 it was necessary to reorganize and to offer new contracts to growers. In spite of the fact that the required acreage of 80 per cent was not secured, reorganization was completed in J une, 1925. Dissatisfaction continued, and in 1929 arrangements were made for the California Prune and Apricot Growers Association to take over the marketing of dried figs.

Dissatisfaction of grower members was largely due to unsatisfactory financial returns. A comparison of prices received from the Association with those from an independent packer show that the latter were much higher than the former. For example, average prices received for 1926 and 1927 deliveries of figs by W. M. Bacon, Fresno, to the Association and to a packer are given by D. L. Kieffer (1929) as follows: for Calimyrnas 2.36 cents and 6.67 cents per pound respectively, for Adriatics 1.66 cents and 3,74 cents, and for Missions 2.22 cents and 6.68 cents. (See also Kieffer, 1928.)

The California Fruit News of March 21, 1936, published this item: "The California Prune and Apricot Growers Association now announces:

I'Association withdraws from fig marketinglet the favored few and the opencontract sellers fight it out.I' " Dissolution of the Fig Association was finally found necessary, but an actual court order approving the dissolution and distribution of its assets was not signed until November 5, 1945. California dried figs are now handled entirely by independent packers.

Since September 1, 1944, a state Marketing Order for Dried Figs and Dried Fig Products has been in operation. Its principal regulatory features, which apply only to packers, are:

1. Minimum grade requirements for marketable whole figs, sliced figs, and fig paste;

2. Inspection prior to shipment of all lots of figs processed;

3. Certification of those lots which meet the minimum quality requirements.

Not over 10 per cent of the figs in any lot may be defective and infestation can not exceed 5 per cent. The objective of this order is to achieve widespread trade confidence and consumer acceptance of California packed figs and fig products. (See W. J. Kuhrt, 1945.) 
Chapter XVIII

163

Economics

For the past few years Calavo Growers of California has handled dried figs along with dates and other fruits; these are packed by commercial firms under the Calavo private label. In 1943 this business amounted to about half a million dollars worth of figs, packed mostly in small cartons of fancy fruit.

Fig I nstitutes: Mention has already been made of the first Fig I nstitute held at Fresno, J anuary 12 and 13, 1917. Sixteen such institutes were held in California, the last one convening at Fresno, November 4, 1932. The meetings were educational in nature and provided a forum for the discussion of practical problems facing growers. They were sponsored by the University of California, by the Agricultural Extension Service of interested counties, and by the California Peach and Fig Growers. Proceedings of the Fig Institutes have been published as follows: the first in 1917, by the J. C. Forkner Fig Gardens, Fresno; the sixth in 1922, by the Fig Association, Fresno; the tenth in 1926, mimeographed by Fresno County Farm Bureau; and the thirteenth in 1929, by the County Agricultural Commission, Merced. These institutes should not be confused with the California Fig Institute, which will be discussed next.

California Fig Institute:The California Fig Institute was formed at a meeting of fig growers and interested persons held at Fresno on February 5, 1935. Its main objective was to do everything possible to improve the quality of dried figs. The Institute was put on a more permanent basis in March, 1936, by the selection of an executive committee of nine fig growers and of an advisory committee of twenty-five. By December 16, 1936, when the first annual meeting of the Institute was held, its success had been so outstanding that D. L. Kieffer (1936) wrote: "From one of the most hopeless, I'has-beenl' farm industries in California, figs have been restored to a profitable business existence/ $/$

A Substandard Dried Fig Diversion Program sponsored by the Institute under the terms of the Agricultural Adjustment Act had as its main purpose the elimination from the market of off-grade figs and their diversion into byproducts channels. The Program, approved by United States Secretary of Agriculture Henry A. Wallace on August 14, 1936, went into effect immediately and was underwritten to the extent of $\$ 250,000$ as a maximum. A subsidiary organization known as the Pacific Dried Fruit Products Association operated as an industry-wide, non-profit organization. The Association was to be indemnified by the government for the amount by 
which the purchase price for substandard figs exceeded the sale price, plus expenses incurred in handling. Up to the 1939 crop season, the government made payments on substandard figs diverted but on a gradually reduced basis from year to year. In 1940 benefit payments were eliminated, and since then the industry has operated its own diversion program without outside financial assistance.

Exact specifications for substandard figs are changed from year to year. In general, such figs may be defined as those which exceed the annual tolerances for defects as established for each marketing season and

\section{Page 164}

\section{Condit 164 The Fig}

the culls sorted out by growers. Substandard figs include large quantities of figs produced in submarginal orchards and in districts not well suited to dried fig production.

\section{VARIETY PRODUCTION TRENDS OF MERCHANTABLE DRIED FIGS IN THE CROP YEARS 1937-1944 . ^^PREPARED BY CALI FORNI A FIG INSTITUTE. FRESNO.}

IQOOO

8,000

^ 6,000

4,000

2,000

T9371938193919401941194219431944

\section{YEARS}

Fig. 27. Variety production trends of California merchantable dried figs, 19371944.

On J une 5, 1933, the State of California approved an act known as the Agricultural Prorate Act, which in several subsequent years was substantially amended. \{See Anon., 1943.) This act provides that upon a favorable vote of two-thirds of the commercial producers, an industry may form a pool based upon grades and quality, and that it may specify the kind of product which 
shall be sold to packers and the kind which must be used only for byproducts. After a successful campaign to sign up the required number of growers, the California dried fig industry began to operate in 1937 under the Agricultural Prorate Act. Since that time all commercial dried figs in Proration Zone No. 1, which includes 18 central California counties, have been subject to the rules and regulations established and adopted by the Program Committee. Prior to each fig-harvest season, a circular letter containing the rules and regulations for that particular crop year and outlining the marketing Program, its purpose, general provisions, and enforcement is sent to all producers, handlers, and processors of dried figs.

[-VTaool'ta ...ADRIATIC

------CALI MYRNA

$-M I S S I O N$ -KADOTA

\section{Page 165}

Chapter XVIII

165

Economics

The Program is administered by a Committee subject to the approval of the State Director of Agriculture. The expenses are met by an assessment which has varied from 90 cents to $\$ 1.10$ per ton. A Diversion Pool is established into which are delivered all lots of substandard figs. The Committee has legal title to such figs and is obligated to return to producers the net proceeds from their sale. Since 1945 the Marketing Program for figs has operated under the authority of the Agricultural Producers Marketing Act.

Table 12 gives the average tonnage of merchantable certificated figs and of substandard diverted figs of the four commercial varieties for the years 1937 to 1944 inclusive.

Table 12.California Dried Fig Report; Averages for Crop Years 1937-19441:

Merchantable Substandard Total

certificated diverted average per cent 
Variety Tons Tons Tons diverted

Calimyrna 61243193931734

Adriatic 920519961120817

Kadota 292823231567

Black Mission 59241610753421

i Data furnished by California Fig Institute.

The California Fig Institute is active in lines other than those directly connected with marketing substandard figs. Director H. H. Hyde in the Tenth Annual Report of the Institute dated J anuary 30, 1945, specifies the following activities: Caprifig cleanup campaign, survey for surplus caprifig trees, cooperative caprification experiment, conferences with food and drug officials, trade promotion campaign, and industry representation with state and federal agencies on such matters as wage rates, price regulations, tariff, and government "set-aside" requirements for figs.

Fig Contract:Each year a fig contract is drawn up in triplicate, specifying the terms and conditions under which dried figs shall be delivered by the seller to the buyer. Most growers usually wait until they have accumulated a quantity of figs before they sign a contract. At the time of delivery, inspection and tests are made by the Dried Fruit Association of California, as already described. The fig contract, revised to J une 23, 1945, contains sixteen regulations detailing conditions of the sale. The amount received by the grower for dried figs depends upon the basis price per ton and the percentage of passable figs. The common practice is for packers to buy figs at a basis price at a fixed basis test between the minimum passable requirement and 90 per cent passable, and to allow premiums for points above and deductions for points below the basis test at the rate of 1 per cent of the basis price.

Canning Figs: Some of the early attempts to market canned figs terminated in financial disaster. The Beckwith Company of Reedley, which pioneered the canning of Kadota figs in California, was forced into

\section{Page 166}

\section{Condit 166 The Fig}

bankruptcy. The California Peach and Fig Growers canned figs on a large scale but failed to market their product at a profit. Records of the Texas fig 
industry give accounts of concern after concern which started with bright prospects of success only to find the venture economically impractical. The marketing of canned figs in California has gradually evolved from open competition among several independent canners to a more or less stable industry carried on by a few large concerns. Section 8.1 of the Agricultural Prorate Act of California, revised to August 4, 1943, exempts canning figs from a proration program.

A cooperative organization of fig growers known as the Federated Fig Growers of California was formed in September, 1927, with headquarters at Merced. The objectives were to promote and to develop markets for Kadota figs. However, this and other attempts to market canning figs cooperatively met with little success until the Kadota Fig Association was organized in 1938. Approximately 85 per cent of the canning figs of California are now controlled by this Association, and its members are located from Earlimart north to Brentwood. A modern canning plant was completed near Merced in 1944 in time to handle a large percentage of that yearl's crop. Some Kadota figs are also allocated to other companies. The business affairs of the Association are handled by a Board of Trustees elected annually by the members, one each from the southern and northern districts, and three from the Merced district. In 1940, growers received 3 cents per pound for No. 1 canning figs. During the past three seasons the delivered price has been 6.5 cents per pound.

\section{Page 167}

Chapter XIX

\section{DISEASES}

/ live forever

I have no disease

And for six thousand years

I have not jailed to produce a crop each year.

Thus did J. C. Forkner (1919a) personalize the fig tree and its unfailing productiveness. The tree is unusually tenacious of life. The list of diseases, however, to which it and especially its fruit are subject is a long one. Fig diseases will be discussed under four general headings: Root Diseases, Trunk and Branch Diseases, Leaf Diseases, and Fruit Diseases. 
Oak-root fungus (Armillaria mellea) causes one of the minor fig diseases in California, France, Algeria, Malta, and Turkey. Fig roots are not immune but do show resistance to Armillaria attack. For example, fig trees planted near Winters, California, in 1860 are still thriving and younger fig trees are growing where peach and apricot trees have succumbed to oak-root fungus. (See E. R. Thurber, 1919.)

Root rot, caused by Dematophora necatrix, is included in the account of fig diseases by F. L. Stevens and J. G. Hall (1910). It causes sudden loss of leaves and premature death of trees.

Ganoderma sessile is reported by C. D. Girola (1922) on fig roots in Argentina.

Fig trees in Arizona are rated as very susceptible to cotton root rot (Phymatotrichum omnivorum) by R. B. Streets (1937), and those in Texas are so rated by J. J. Taubenhaus and W. N. Ezekiel (1936). In 1912 F. D. Heald and F. A. Wolf found the disease in two fig nurseries, where it caused serious loss of cuttings. This root rot has not so far been reported from fig districts of Europe or of central California.

The bacterial disease known as crown gall, caused by Phytomonas tumefaciens, has been produced on fig branches experimentally by $\mathrm{C}$. $\mathrm{O}$. Smith (1913). Crown gall has been found on the roots of Adriatic trees near Fresno. (See Condit, 1921a and F. P. Roullard, 1923.)

TRUNK AND BRANCH DISEASES Bacteriosis:Bacteriosis, or gummosis, caused by Bacterium fici, is a disease of fig trees in Italy, where it is known as "Marciume del fico." Accounts of it have been given by L. Savastano (1923), F. Cavara (1905), L. Petri (1906), and T. Ferraris (1926). Bacteriosis, known since the time of Theophrastus, is most apparent from J uly to September, when it may cause both leaves and fruit to wither and fall. The chief seat of the disease is in the roots, which turn dark and split open or decay. Savas-

\section{Page 168}

\section{Gondit}

168

The Fig

tano found exudation of gum at the junction of young and older roots and also on the trunk and branches. The composition of the gum was similar to that of gum produced in gummosis of the olive. In fact, gummosis of the fig is similar to that of the peach, almond, plum, olive, and even of citrus. It may be the result of an injury; in some cases the external cause is not in evidence. 
Blights: Limb blight, caused by Corticium laetum, was described by C. W. Edgerton in 1911 as a new disease of the fig in Louisiana. "It is characterized by the bright salmon colored fructifications which cover the branches and by the sudden wilting and dying of the leaves on the affected portions .... The fungus generally gains a foothold in the tips of the branches that have been killed by the fig canker or by fig borers." O. F. Burger (1923) reported limb blight (C. salmonicolor) as a serious disease in Florida. "The fungus usually was found first on the smaller branches, gradually working its way down to the larger limbs, causing extensive injury by killing large limbs. Pruning proved an efficient control method."

According to J . J. Taubenhaus and J. N. Roney (1935), a serious twig blight made its appearance near Dickinson, Texas, causing a loss of over 50 per cent of the crop in one orchard besides serious defoliation of the trees. The causal fungus was identified as Botryosphaeria ribis.

Thread blight is so called because of the conspicuous mycelium on leaves and twigs. A technical account of the fungus, Corticium stevensii, is given by G. F. Weber (1927). According to E. C. Tims (1934), an unusually early and severe outbreak of thread blight occurred on a group of several young fig trees near Baton Rouge, Louisiana, during the early part of J une. Within a period of a few days the trees were practically defoliated and the fruit destroyed. The disease may be controlled by spraying with bordeaux mixture and by pruning.

Cankers: There are at least five fungus diseases of the fig tree which have been designated as canker. According to George Masses (1911), the fungus Libertella ulcer at a is frequently the cause of serious injury to fig trees grown under glass in England. This was later ascribed to Phoma cinerescens by E. S. Salomon and H. Wormald (1916), who reported it as a serious disease on outdoor trees in Sussex.

L. Maffei (1925) found a similar canker attacking fig trees at Zerbolo, Italy, and identified the causal fungus as Phomopsis cinerescens. A good account of it is given by Pietro Grancini in 1938. O. A. Drummond (1941) reported this fig canker in Brazil and found no previous reference to the disease in America. The same year, however, R. E. Smith (1941) described it as occurring in California on neglected or injured trees.

In 1911 F. A. Wolf found that a fruit decay of purple figs in Texas was caused by Macrophoma fici. In one grove it caused the loss of about one-half the crop. Wolf and E. E. Stanford (1918) reported that the disease manifested itself also by the presence of cankers upon the larger limbs but not on current growth. Cortex of the bark is ruptured, and longitudinal fissures form on account of desiccation of the cankerous tissue. 
Chapter XIX

169

Diseases

H. A. Edson and J essie L. Wood (1937) reported this canker in Louisiana for the first time. Diseased branches may be pruned out and destroyed.

The fourth cankerous disease of the fig tree is caused by Tubercularia fici. C. W. Edgerton (1911a) states: "The disease is characterized by the shrinking and drying out of the tissue surrounding a fruit scar, accompanied by an increased growth of the healthy surrounding tissue, and followed later by a dropping out of the dead part, leaving an open wound in the branch $/$ ' It was not regarded at the time as a serious disease in Louisiana. In 1925, however, N. J. Giddings and J essie I. Wood reported that this canker affected over 20 per cent of the fig trees in Georgia and reduced the yield about 10 per cent.

Fifth on the list of canker-forming fungi is Septobasidium pedicillatum. It was reported by Giddings and Wood to be rather general in Mississippi but of only moderate importance.

Die-Back:Die-back of fig branches in California was described by Condit and $\mathrm{H}$. J. Stevens in 1919. Two fungi were isolated from dead and dying branches. One, a species of Sclerotinia, can be recognized by the soft, shreddy condition of the bark of dead twigs and by the presence of sclerotia in the pith. It is of minor importance only. The second fungus concerned with die-back is Botrytis cinerea. One source of infection is moldy figs from which mycelia grow into the wood. Botrytis causes serious trouble to occasional trees in coastal districts of California. R. E. Smith (1941) refers to these two diseases as "limb blight," and identifies the first as S. sclerotiorum.

A Sclerotinia limb blight of figs is described by J. J. Taubenhaus and W. N. Ezekiel (1931) as serious in Galveston County, Texas, on Brunswick fig trees. The disease, first noticed as a sudden wilting of the foliage, gradually involved large portions of the affected trees, including the trunk. The sclerotia were found to resemble those of Sclerotinia sclerotiorum.

In 1918 A. Prunet and B. Aggery gave an account of a Botrytis disease of fig branches in France. In 1904 M. C. Cooke reported that Botrytis, long regarded in England as a saprophyte, was found to be causing the decay of fig fruits. W. B. Brierly (1916) proved the pathogenicity of the fungus by inoculating fruit and twigs with a pure culture of Botrytis. It carries over the winter in mummified fruits and in dead twigs. Sclero-tium blight, due to 5. rolfsii, is described by J. Matz (1918) as a disease which sometimes occurs on fig trees in Florida, attacking mainly the trunk of the tree. 
Stilbum Disease:A new fig disease has been described by E. C. Tims (1933) ; the fungus causing it was identified as Stilbum cinnabari-num. A more complete account was published in 1935. Celeste fig trees in Louisiana were severely damaged; Brunswick fig trees, if affected at all, were much less severely injured. Attention was first drawn to the disease by the presence of dead twigs scattered throughout the tree. The fungus sometimes spreads into larger branches and destroys the entire tree. No Stilbum infection has been observed on either the leaves or the fruit. The

\section{Page 170}

Condit

170

The Fig

Stilbum disease can be controlled in young trees by pruning out infected branches, but old, badly diseased trees should be destroyed.

Decline:The word "decline" is used here to describe those diseases whose causes are not readily determined. Condit (1921a) has discussed some of the factors responsible for fig-tree decline including high water table, nematodes, and crown gall. Neglect should also be named although it seldom accounts for the death of a fig tree. In fact, abandoned trees are commonly found to be thriving in spite of neglect. Failure of fig trees to make healthy growth, either in orchards or in dooryards, is more often due to some obscure root or soil condition than to any disease or pest on parts above ground. There may be either a deficiency or an excess of certain chemical elements. The effects of fluctuating water table and of saline soils on tree growth are discussed in chapter XIII.

Sunburn of the trunk or large branches may cause tree decline. Such injury is especially likely to occur in winter when the trees are leafless and the sunl's rays strike the bark more directly than in summer. Whitewashing of exposed parts will prevent sunburn injury; however, whitewashing the trunks of fig trees every season, a practice of some growers, is of no real value.

Lichens, commonly known as moss, often grow freely on the trunk and larger branches of fig and other fruit trees. These are not parasitic for they live on the dead outer bark; they may at times harbor insects or fruit-decay organisms. When it is deemed necessary to destroy lichens, a winter spray of bordeaux mixture or of lime-sulfur will prove effective.

Guglielmi (1908) designates a quick decline of fig trees in Lecce Province of 
Italy as "Apoplessia linfatica," or "apoplexy." He says it is not uncommon to see the leaves of a fig tree become yellow and drop in midsummer, even though the roots appear healthy. Trees in California, especially those of the Lob Injir variety, occasionally show a similar form of "apoplexy," as yet unexplained.

\section{LEAF DISEASES}

Spots and Blotches: A disease reported by G. Arnaud and M. Arnaud (1931), to form spots 5 to $15 \mathrm{~mm}$ in diameter on fig leaves in France and designated by them as Aschochyta caricae is probably Cerco-spora bolleana. (See P. A. Saccardo, 1886.)

A leaf spot of fig, caused by Cephalosporium acremonium, was observed on a single Celeste tree near Houma, Louisiana, in 1939 and again on several trees in 1940. The fungus causes leaf spots, the centers of which fall out late in the season. (See E. C. Tims, 1941.)

Heald and Wolf (1911) reported a leaf blotch (Cercospora fici) which appeared in late summer on fig leaves in Texas. "The disease was very abundant in several localities, involving half the leaf surface and causing the leaves to fall." A yellow rust of fig leaves, ascribed by Stevens and Hall (1910) to Fusariwm roseum, caused yellowish spots which fell away and gave the leaf a ragged appearance. Phyllosticta fici-carici was described by B. V. Rothers (1928) as a new species causing dark brown, irregular spots on fig leaves in the Caucasus.

\section{Page 171}

Chapter XIX

171

\section{Diseases}

Another disease, caused by Mycosphaerella bolleana, is variously known as leaf spot, leaf blight, leaf blotch, and rusty leaf. Massee (1900) reported it as widely distributed in the Mediterranean region, Austria, Argentina, and England. Heald and Wolf (1912) found that in Texas the spots cause yellowing of the foliage and much early defoliation of fig trees.

In 1917 J. Matz stated that Rhizoctonia micro sclerotia, a new species, was causing a leaf blight of the fig in Florida. The following year Matz stated that diseased areas became silvery white on the upper surface of the leaf and brown on the lower surface. The fruit was sometimes overgrown by the fungus and was covered with numerous small sclerotia. According to E. C. 
Tims and Frances Bonner (1942), this Rhizoctonia has caused severe injury to fig trees in Florida and southern Louisiana and also some damage in Texas.

Rust: Rust, caused by Physopella fici, is the most cosmopolitan of the leaf diseases of the fig tree, but fortunately it is not serious in drying-fig districts.

Development of the fungus is apparently hastened by high atmospheric humidity, and in many countries it causes complete defoliation unless controlled. Most early accounts of this disease minimize the damage done by the rust fungus. C. W. Edgerton (1911a), for example, reported that, in spite of early defoliation, "the young leaves and shoots come out in the following spring with as much vigor as ever."

In commercial fig districts of Texas, on the other hand, W. B. Lanham et al. (1927) stated that rust "causes much of the Magnolia fig crop to be unfit for market. . . . Probably the greatest damage to the fruit is from sunburn after the leaves have fallen." They recommended that fig trees be "sprayed with bordeaux 5-5-50 as soon as the disease appears which is usually about J uly 15. Subsequent applications should be made often enough to protect new leaves and fruit until the last fruit is mature, probably on the average of every thirty days after July 15 until at least September 15."

G. F. Weber (1931) suggests a 4-4-50 bordeaux spray for control of fig rust in Florida, but says that "spraying should be discontinued when the young developing fruits are one-fourth inch in diameter, because the spray sticks to and discolors them. One or two additional applications of spray should be made after the crop of fruit has been harvested to prevent infection and premature shedding of the leaves."

Mosaic: Mosaic is a virus disease which was almost entirely overlooked in the literature until 1933 when Condit and W. T. Horne published an account of it. Further notes were contributed by them in 1941. Mosaic has since been reported from England, Egypt, Australia, and China. It is apparently not present on fig bushes or trees of the eastern and southeastern sections of the United States.

Fig mosaic manifests itself on both the leaves and the fruit. On the leaves the mosaic spots are sometimes sharply delineated, the light green color of the affected areas strongly contrasting with the normal green of the foliage. Seldom does the mosaic bring about an actual necrosis, or

\section{Page 172}

Gondit 


\section{The Fig}

dying out, of whole areas of leaf tissue. Another expression of this mosaic is the malformation of leaves.

Mosaic spots on fig fruits are, like those on the leaves, generally distinguishable by their light green color. In one variety of caprifig, the Samson, mosaic spots are conspicuous as more or less concentric rings and cause premature drop of the profichi. A similar ring spot has been commonly found by Condit and Horne (1943) on seedling caprifigs in California. H. A. Pittman (1935) reported that in Western Australia the disease "not only affects the leaves but frequently causes the first crop of figs to fall away without developing normally, and it may interfere also, at times, with the development of a considerable proportion of the second crop.,,

Fig seedlings kept isolated from other fig trees are free of mosaic. Buds taken from these seedlings and inserted in orchard trees usually show mosaic symptoms after they have made a growth of two or three years. When planted in the orchard on their own roots, seedling figs also may become mosaiced. The vector for fig mosaic is not definitely known but the fig mite is suspected.

\section{FRUIT DISEASES}

Dropping:The dropping and the splitting of fig fruits are two troubles not usually associated with any pathogens. Most of the reasons for the failure of figs to set and mature are given in chapter IV under Parthenocarpy. Eisen (1901) stated that the most common cause for fig dropping was unfavorable climate; he believed that in some cases the only remedy was to find by experiment which varieties were suited to the climate. This advice is applicable today. In case a healthy fig tree persists in dropping most or all of its fruit season after season, the logical procedure is to replace the tree or to top-work it with a variety which is known to fruit well in the vicinity.

Splitting:La Quintinie had this to say about splitting of French

figs:

The round figs come in more abundance and the long ones are especially most admirable about the end of autumn when they can attain to their due ripeness because they are not so subject to split and chap towards their crown as the round ones are, which fault ordinarily proceeds from some hot rains that fall in the month of October that make those poor round figs to swell that they gape towards the head with clefts enough to fright one and thereby vent and let out all their sweetness and perfume. (Translation by J ohn Evelyn, 1693.) 
Spherical or oblate figs apparently do have a greater tendency to split than figs elongated or pyriform. Lob Injir, oblate in shape, splits badly in some districts and not in others. Hagan reported that in 1928 split figs averaged one in seven in orchards at Reshadie, Turkey, by far the greatest damage occurring between Baladjik and Karabounar. In California, Lob Injir is more subject to splitting than any other commercial variety, a statement contrary to that of Rixford (1915) who wrote: "This trouble is not confined to the Smyrna variety, but is even worse in the Adriatic.,, The Stanford variety, disseminated as a non-splitting Smyrna-

\section{Page 173}

\section{Chapter XIX 173 Diseases}

type fig, is resistant to splitting even though it is spherical in shape. \{See Rixford, 1920.)

Splitting generally starts when the figs are firm and before they reach full maturity. Unfortunately, the largest and finest fruits are those most inclined to split. The trouble usually starts at the apex and may divide the fig into two, three, or four segments. Splits along the side of the fruit occur but are not so common as at the apex. Figs with dark-red pulp, such as the Bardajik, show up conspicuously on the tree when the fruits split.

Various explanations have been advanced for the splitting of fig fruits. Howard (1901) believed the expansion was due to the abundant secretion of sugar. Condit $(1918,1919)$ summarized the trouble by stating that splitting "seems to be due to abnormal water relations in the fruit and leaves brought on by irregular moisture in the soil or atmosphere/ $\mathrm{I} J$. E. Coit (1921) concluded that "splitting is a purely physical phenomenon due to the inherent weakness of the Smyrna fig and its inability to withstand the turgor arising from excessive sap pressure."

Smith and Hansen (1931), in their account of fruit spoilage of figs, concurred that climatic conditions, such as lower temperature and greater humidity, are responsible for splitting. They concluded that if splitting of the figs is really due to atmospheric humidity, the production of good figs is physically impossible under certain climatic conditions.

Smut: Fig smut, caused by Aspergillus niger, gets its common name from the mass of black, powdery spores discharged from the interior when an infected dry fig is squeezed between the fingers. A writer in the Gardenerl's Chronicle for April 24, 1852, says that a mold occurs now and then in imported figs which look perfectly sound externally, "but when eaten, like the apples of Sodom, fill the mouth with loathsome dust." 
Smut has long been recognized by California fig packers, but very little was known about it until 1918, when R. W. Hodgson in two published accounts of the disease showed that it was apparently the same fungus that causes an internal rot of pomegranates. A study of fig smut started in the summer of 1920 by Edith Phillips resulted in 1925 in a complete account of the disease. (Edith Phillips et al., 1925. See also Anon., 1921; Elizabeth Smith and Edith Phillips, 1922.)

The fungus, A. niger, is a common mold of universal occurrence on decaying vegetable matter. Figs become infected when they are still on the tree, just as the eye opens and the fruit begins to soften. Infection is largely due to the dried-fruit beetle, which breeds commonly on decayed vegetable matter. The conclusion is that control of smut depends largely upon sanitary measures to eradicate the breeding material of the beetle. It is likely also that smut spores are carried into green figs by thrips. In $1943 \mathrm{H}$. N. Hansen recommended the spraying of Adriatic fig trees with a one per cent solution of lime sulfur before the middle of May and again before the middle of J une in order to reduce loss from smut and mold.

Souring:The etiology of souring and of smut is very similar. Both fig diseases are largely due to the activities of insects such as dried-fruit

\section{Page 174}

\section{Gondit}

\section{4}

The Fig

beetles, vinegar flies, thrips, and mites. That this fact has long been recognized is indicated by the report of B. T. Galloway (1893) regarding the investigations of Newton Pierce in California. Pierce found that fig growers had to contend with a destructive fermentation of the fruit which often caused the loss of nearly the entire crop. Figs soured not only on the trees but also in the drying yard. Pierce isolated a yeast capable of exciting fermentation, and found it to be carried into the ripening fruits by insects.

Extensive investigations on fig souring have been carried on by the Division of Plant Pathology, University of California, Berkeley. Results of these and other investigations are given by Smith and Hansen (1931). Evidence that insects are the chief agents in the introduction of microorganisms to the interior of the fig was gained from an experiment in which two large Adriatic fig trees were enclosed with muslin supported by a wooden frame.

Temperature inside the enclosure was somewhat lower than it was outside and the humidity was greater. No souring of figs occurred on the enclosed 
trees although it was abundant on all the neighboring trees outside. Further experiments by P. D. Caldis (1926, 1930), A. E. Davey and R. E, Smith (1933), and B. J. Howard (1933) confirmed the fact that figs unprotected from insect infestation sour badly and that those protected reach perfect maturity.

It was emphasized by Smith and Hansen that the term "souring" is a loose and indefinite one. " $\backslash$ 'Sour' ' and \'not sour* may at times have meant nothing more than different degrees of the same thing and not the absolute presence or absence of a specific infection." H. N. Hansen (1929), furthermore, studied the importance of thrips as carriers and found that when green, hard figs are entered by thrips, they become inoculated with organisms capable of producing various decays in the ripening fruit. Experiments reported by Hansen and A. E. Davey (1932) demonstrated that predaceous mites and thrips are also carriers of microorganisms.

The organisms involved in fig souring are listed and described by various investigators, including Hansen (1929), Davey and Smith (1933), and E. M. Mrak et al. (1942). Most of this form of spoilage appears to result from the association of acetic acid bacteria and yeasts, principally species of Saccharomyces or of Candida.

The above discussion leads to the conclusion that souring is primarily due to insect infestation and that control of the dried-fruit beetle would largely prevent it.

Endosepsis: The name "endosepsis," meaning internal rot, was suggested by P. D. Caldis for a specific disease of the fig caused by Fusarium moniliforme var. fici. Caldis $(1925,1927)$ thoroughly investigated this disease and found that the fungus occurs in caprifigs and is carried into other figs by the blastophaga. The causal organism lives at first on the dead stigmas but eventually fills the caprifig interior with a white mold. Symptoms of endosepsis in edible figs are not always visible externally for it progresses from the cavity of the fig outwards. Sometimes the fungus affects only the pulp, which often becomes slightly watery and

\section{Page 175}

Chapter XIX

175

Diseases

easily separates from the meat. When the skin is affected, it takes on a watersoaked appearance in indefinite areas around the eye, and these areas 
gradually assume a pink or purplish coloration. Caldis states that figs affected with endosepsis have no odor, but adds that "in some cases, however, there is a very disgusting, putrid, somewhat bitter taste, very characteristic but impossible of description, and an odor which suggests that of spoiled tomatoes."

Although Caldis identified the fungus and solved the methods of its transmission, the problem of satisfactory control still remained. This was worked out in a series of investigations by H. N. Hansen beginning in 1926. He conceived the idea of treating the interior of caprifigs with a fungicide in such a manner as to destroy the fungus without injuring the blastophagas inside the seed-like ovaries. As injection of fungicides with a hypodermic syringe was found to be impractical, the dipping method was developed in 1927. \{See Hansen, 1927, 1928, and Smith and Hansen, 1931.) This consists in gathering the mamme figs from the trees when they are mature and ready for issuance of the blastophaga, splitting them in two, and dipping them in the fungicide. With minor modifications, this treatment of caprifigs has been accepted as a necessary procedure by intelligent growers of Smyrna-type figs. Common-type figs also become infected with endosepsis if the fruits are caprified.

Instructions for the control of endosepsis are issued from time to time by the California Fig Institute. Briefly, the procedure is as follows: remove all mamme figs from the trees in March, before any blastophagas have issued; sort out and destroy all frozen, bruised, or defective figs; store the good mamme figs in a cool place until time for colonization of profichi; cut and split the mamme figs into halves; submerge in a solution of Semesan, 1 ounce to 4 gallons of water, for 15 minutes; dry the figs as quickly as possible and place them in containers in the caprifig trees; remove the treated mamme figs at the end of four days and destroy them or treat them again with the Semesan solution and place them a second time in the trees. Evidence at present indicates that removal from the tree and treatment of mamme figs is necessary every year to ensure control of endosepsis.

In March of 1943, Hansen emphasized the fact that of alt varieties grown in 1942 the Calimyrna crop had the highest percentage of culls, more than 32 per cent. "There can be no doubt/ $\backslash$ ' stated Hansen, "that the major part of this 32 per cent loss is caused by endosepsis, a disease which can be greatly reduced by proper clean-up of the caprifigs, but such cleanup must be done now and it must be done thoroughly."

The California state law \{see Agricultural Code, State of California, 1943, chapter 6) specifies that every person who handles caprifigs for market "shall cause same to be treated by a method approved by the [county] commissioner for the prevention or elimination of endosepsis. . . . Every person who wilfully or otherwise interferes with the enforcement of the provisions of this chapter is guilty of a misdemeanor." 
This disease is not restricted to California. H. R. Hagan (1929a) found that in the fig district of Smyrna the average amount of fig spoilage

\section{Page 176}

\section{Gondit}

176

The Fig

due to endosepsis was 6.6 per cent. O. Schwarz and A. Vasfi (1933) give a table which seems to show that 59.2 per cent of all fig spoilage in Asia Minor is due to endosepsis. A malady of figs in Kabylia is reported by P. Tessier (1937) to be carried from caprifigs to edible figs.

Black Spot:Figs ripening on the tree often develop black spots on their surface. These spots are especially common on Dottato figs and make them unacceptable to the cannery. The cause of the spotting is a common fungus, a species of Alternaria, the development of which is favored by high humidity. Figs picked for canning should be kept as dry as possible and should not be left in lug boxes any longer than necessary. (See Smith, 1941.) C. Brooks and L. P. McColloch (1938) reported that spots found on figs in the fresh fruit market were due mainly to Alternaria tenuis, but Cladosporium herbarum was occasionally found in infected tissues. Lowering the humidity in storage decreased the spotting, but a humidity sufficiently low to control spotting caused the fruit to shrivel.

Fruit Rots:There are several species of fungi which may at times cause serious rotting of fresh figs. Botrytis cinerea was regarded by Massee (1911) as the cause of a soft rot of figs grown under glass in England.

According to J. J. Taubenhaus (1936), a peculiar disease was found attacking figs in all stages of development in Galveston County, Texas. Almost pure cultures of a fungus, Choanephora cucurbitarum, were obtained from the decaying fruit.

Stevens and Hall (1910) stated that in Louisiana a new anthracnose was causing great damage to figs "by reason of premature falling of the fruit, at times destroying the whole crop." This anthracnose was also described by Edgerton (1911) as a disease of the fig fruit, causing it to rot and become worthless. He found the causal fungus to be the same as that which produces bitter rot of apples, namely, Glomerella fructigena. The Reine Blanche and Celeste varieties were resistant to the disease. In 1918 J. Matz reported this disease in Florida as Glomerella cingulata. 
The common bread mold, Rhizopus nigricans, is commonly associated with a soft rot of figs. Edgerton (1911) aptly describes it as a "trouble which is well known to every one who has ever raised figs. The trouble occurs chiefly during rainy spells in the summer when the fruit is ripening. The fruit sours, becomes soft and rotten, and, finally, generally falls to the ground. At the time the fruit falls, it is generally so soft that it all goes to pieces when it strikes the ground." In California, Rhizopus and a species of Mucor are both responsible for soft rot of figs, but they are prevalent mostly in humid weather.

A Phytophthora rot, regarded by Y. Nisikado et al. (1941) as properly belonging to P. palmivora, causes fig spoilage in J apan. M. K. Venkata Rao (1916) reported this fig disease from Mysore, India, as P. fici. A fungus causing rotting of figs in Hawaii in 1941 was identified by J. P. Martin as P. carica. (Personal letter dated Oct. 10, 1941.)

\section{Page 177}

\section{Chapter XX}

\section{INSECTS AND OTHER PESTS}

The list of insects and other pests which attack the fig tree or its fruit is, like that of diseases, a long one. Fortunately only a few injurious species occur in any given locality. Fig pests will be discussed under the general headings "Pests Other Than Insects/ $\wedge$ ' "Insect Pests of the Tree," "Fresh-fruit Insects," "Dried-fruit Insects." In addition to references made in the text, four others of general interest may be noted: P. Th. Anagnostopoulos (1939), A. Balachowsky and L. Mesnil (1935), C. H. Ballou (1936), and F. Picard (1919).

\section{PESTS OTHER THAN INSECTS}

Nematodes:The root-knot nematode, Heterodera marioni, is a minute worm which penetrates the fibrous roots of the fig tree and causes a bead-like swelling, or knot, to develop. The injured roots die and rot, whereupon the plant produces new rootlets to replace those that have succumbed. According to E. A. Bessey (1911), root-knot is of almost universal occurrence on a very large number of host plants and is essentially a disease of light soils. In California, however, J ocelyn Tyler (1944) found severe infestations in heavy soils. J. R. Watson and C. C. Goff (1937) reported that "in most parts of Florida with sandy soils, figs are successful only when planted near a building under which their roots can run."

Certain southern varieties, for example, Celeste and Poulette, are said by Bessey to. be less subject to injury by nematodes than other kinds, but at Riverside, California, not a single one of more than 120 fig varieties or of a 
large number of seedlings tested showed freedom from root-knot. There is some evidence that certain trees grow and thrive in spite of nematode infestation, and such trees should be tested for their possible value as rootstocks. The use of Ficus glomerata as a nematode-resistant stock is discussed in chapter XII.

A. L. Taylor (1943) reports the results of tests made of fig seedlings in Georgia, some grown in nematode-free soil and others grown in infested soil. "After four months all of the infected seedlings but one were dead and this one died shortly after. All of the uninfected seedlings were living and had grown to an average height of $25.7 \mathrm{~cm}$. The results of this experiment leave no doubt that the seedlings had neither resistance nor tolerance to root-knot."

No effective remedy for root-knot is known. A. W. Cressman suggests that conditions for tree growth be made as favorable as possible. Trees may then grow and bear fairly well in spite of a considerable infestation of nemas. Experiments in southern United States show that mulching the surface of the ground under and around fig trees fosters tree growth.

\section{Page 178}

\section{Gondit}

178

The Fig

According to J. R. Watson and H. E. Bratley (1944), "nearly as many knots are found on the roots of plants under the mulch as in the checks, but there are definitely more healthy roots on the plants under the mulch.,,

Extensive tests have proved Crotalaria spectabilis to be one of the very few plants that are immune to this nematode. According to G. Steiner (1942), "current investigations show that its roots are entered by the larval root-knot nematode but that very few of these invaders make any developmental growth, that only occasional specimens grow to the adult stage, and that none has yet been found to produce eggs and progeny.,, The use of Crotalaria as a trap crop for nematodes is a promising development in the long battle to overcome the ravages of this pest.

The problem of nematode injury to fig roots is complicated by the fact that species other than the root-knot nematode are also involved. The meadow nematode, Anguillulina pratensis, has, according to Gerald Thorne (1934), been observed on fig roots in California since 1920. "Severely infested trees are readily distinguished by their retarded growth and by a conspicuous reduction in the number and size of branches. Usually the tap roots of such 
trees are dead and the lateral roots show various degrees of damage, ranging from slight injury to complete destruction." The banana nematode, Pratylenchus musicola, is also found on the fig, causing destruction of the axial cylinder of roots. \{See Steiner, 1940.) There is no practical remedy for injuries caused by either of these nematodes.

Mites:The fig mite, Eriophyes fici, is almost invisible to the unaided eye, but its presence can usually be detected by the rusty color of the bracts within the ostiolum of the fig. The mites are often found in immense numbers on the bud scales and very young leaves. A good account of this mite and of other species found on the fig tree is given by E. W. Baker (1939). It is seldom injurious in commercial orchards, but on dooryard trees it may cause terminal leaves to drop. The use of a 2 per cent medium oil spray is recommended in case remedial measures are necessary.

The Pacific mite, or red spider, Tetranychus pacificus, is a serious pest, especially of the Dottato (Kadota) fig tree. It injures the foliage and spots the fruit. Healthy, vigorous trees are less susceptible to injury than are trees whose vitality has been reduced, usually by lack of sufficient soil moisture. At the first indication of infestation, treatments for control should be applied. Dottato fig orchards in California are so extensive that sulfur dusting by airplane has been practiced to some extent. Oil sprays also are now being used for red spider control.

Mites are sometimes found on dried figs. H. M. Morris (1920) found Carpoglyphus anonymus heavily infesting figs received from Liverpool. Perez Simmons et al. (1931) report that infestations of Carpoglyphus passularum have been observed in which the figs were "fairly alive with slowly crawling mites of this species. When present in such numbers they impart a somewhat disagreeable odor to the fruit."

\section{Page 179}

\section{Chapter XX}

\section{9}

Insects and Pests

Birds:In Italy the garden warbler, Sylvia hortensis, is known as "beccafico," or "fig-pecker," on account of its fondness for figs. Mrs. W. B. Bernard (1866) states that the beccafico is described by Vieillot as "like a small lump of light fatsavoury, melting, easy of digestion, and, in truth, an extract of the juice from the delicious fruits it has fed upon."

In commercial fig orchards of California, damage by linnets and other birds is 
sometimes severe. S. E. Piper (1944) states that "control of linnets is characterized by very great returns in comparison with the expense incurred." At Fresno, a cooperative linnet-control program was instituted by 27 landowners on 9858 acres and resulted in a net saving of 5 per cent of the crop value.

Gophers: Fig roots are very susceptible to the attacks of gophers; these rodents should be controlled by trapping, poisoning, or drowning.

\section{INSECT PIESTS OF THE TREE}

Coleopterous Borers: Various coleopterous borers are serious pests of the fig tree, especially in tropical countries. According to M. A. Husain and M. A. W. Khan (1940), Batocera rufomaculatus is so great a pest in certain parts of India that fig growing is practically impossible. The grubs tunnel mainly in the wood and do not injure the bark. Trunks may be protected by wire gauze or by spraying with a strong, repellent mixture. Both Batocera lineolata, reported by T. Kojima (1929), and Apriona rugicollis, reported by C. P. Clausen (1931), attack fig branches in Japan.

T. B. Fletcher (1919) reports that in Pusa, India, Aclees cribratus bores in main stems of fig trees. A. Balachowsky (1929) states that the cerambycid Hesperophanes fasciculatus, widely distributed about the Mediterranean Sea, is very injurious to figs, working generally in wood of the current year.

According to J. L. Lichtenstein and F. Pi card (1917), the damage done to Old World fig trees by Hypoborus ficus is considerable since it has three or more generations annually. Various parasites and predators help to keep it under control.

Hylesinus fici is a broad, hairy, brown beetle common in eastern New South Wales, where it tunnels in the branches of both wild and cultivated figs (K. C. McKeown, 1942). Damage done by the three-lined fig-tree borer, Ptychodes trilineatus, is discussed by J. R. Horton (1917) and by Cressman (1935). Horton states that this beetle occurs throughout southern United States, although Cressman reports that it has been definitely identified as damaging fig trees in Louisiana and Texas only. The beetle is characterized by three scalloped white stripes extending almost the full one-inch length of the back. Most of the damage is done by the larvae, which mine their way into the larger branches and trunk. It is easier to prevent damage by this borer than to cure it. Since the beetles prefer wood that has been injured in some way, they can be controlled by keeping the tree in a healthy condition and by treating all wounds with some protective compound.

The fig and willow borer, Phryneta spinator, is native to South Africa, 
Gondit

180

The Fig

where it has adopted the weeping willow and the fig as favorite host plants. The larvae live two and one-half years and their burrows are sometimes three feet long. Control measures include screening the trunk to prevent egg laying and killing the larger larvae in the burrows by means of a flexible wire. (See D. Gunn, 1919, 1930.)

Coleopterous borers of minor importance as fig pests are reported as follows: in Victoria, Bostrychopsis jesuita, by C. French (1909); in Brazil, Colobogaster quadridentata, by G. Bondar (1923) ; in Algeria, Niphona pecticornis, by M. Delassus et al. (1930) ; in Brazil, Heilipus bonelli, Taeniotes scalaris, and Trachyderes thoracicus, by G. Bondar (1913); in Italy, Sinoxylon sexdentatum, by G. Grandi (1930) ; in Africa, Sinoxylon sudanicum, by H. H. King (1911) ; and in Australia, Xylobosca bispinosa and Dihammus vastator, by K. C. McKeown (1942).

Lepidopterous Borers: The pyralid, Azochis gripusalis, attacks fig branches in Mexico and also in Brazil, where it causes serious injury to cultivated fig trees and to native trees of the sub-genus Urostigma, (See Bondar, 1920.) In Sicily, according to S. Monastero (1930), the larvae of Cossus cossus prefer the fig to the apple and other trees as food.

Other lepidopterous fig borers are reported as follows: Pachylia ficus, by Bondar (1913), injurious in Brazil; Stenoma albella, by H. von Ihering (1911), also injurious in Brazil; and Tortyra fulgens, by J. Wille (1937), injurious in Peru.

Scale Insects: Of the scale insects found on fig trees only a few species are of economic importance. The following may be consulted for species not included here: C. K. Brain (1918-1920) and also H. K. Mun-ro and F. A. Fouche (1936) for species of South Africa, and Gustavo Leonardi (1920) for those of Italy.

The Mediterranean fig scale, Lepidosaphes ficus, infests fig trees in the Old World and has been established in California for at least 40 years. According to G. F. Ferris (1938), L. ficifoliae also occurs in California. L. ficus seems to occur normally on the twigs. In a letter to Ferris dated Jan. 12, 1940, S. E. Flanders reported the results of transferring to clean plants the newly hatched progeny of the leaf-inhabiting scale. Most of the parent stock consisted of the form L. ficifoliae. Flanders stated: "The progeny of ficifoliae infested both the stems and the leaves but in doing so they became segregated according to sex, the males infesting the leaves and the females (and a few males) infesting the stems. The males emerged in October while 
the females were still very small. Apparently only the females overwinter. Casual observations of the habits of this species indicated that there are only two broods, an overwintering brood (ficus) and a summer brood (ficifoliae)" In a reply dated Jan. 13 , Ferris stated that if this observation is confirmed, "it will be, I think, the first demonstration of an actual structural, seasonal dimorphism in the scale insects/ ' V. Lupo (1943), however, has shown experimentally that $\mathrm{L}$. ficifoliae is a form of $\mathrm{L}$. ficus (Mytilococcus conchiformis) and not a distinct species.

The fig scale resembles rather closely miniature oyster shells, the male

\section{Page 181}

Chapter XX 181 Insects and Pests

and female scales being much alike. The presence of the fig scale causes yellowish spots to develop on the leaves; their presence on the fruit causes vivid green spots, which make a strong contrast to the normal fruit color.

Apparently there are three generations of this scale in central California each year. Wind is probably one of the chief factors involved in spreading the scale insects, although they may be carried on fig cuttings or on capri-figs. In Europe, fig scale is rarely if ever a pest, apparently being kept under control by natural enemies. One of these has been introduced into California (Flanders, 1942), but establishment has not yet occurred. Recent experiments show that fig scale can be controlled by the use of a tank-mix spray containing 3 or 4 per cent heavy dormant oil or an equivalent amount of oil from emulsions.

The fig wax scale, Ceroplastes rusci, is not found in California but is widely distributed in Mediterranean fig districts. According to F. Sil-vestri (1927), infested trees are weakened by the scale, and the ripening of the fruit is delayed or prevented. In coastal areas of I taly, the females oviposit in late May and early J une, and in sheltered positions there may be two generations a year. G. E. Bodkin (1927) reports that this scale flourishes in fig-producing areas of Palestine at elevations of 1500 to 2900 feet above sea-level, but that in coastal areas it is almost unknown. A sootlike mold grows on the sticky exudations of the scale. In most fig districts, C. rusci is partially controlled by predaceous beetles and chalcid parasites. Other reports of this scale are: from Algeria by L. Trabut (1901), from Portugal by A. F. de Seabra (1918), and from Italy by G. Martelli (1925). Hagan (1929) did not find it to be a serious pest in the Smyrna fig district.

The pustule scale, Aster olecanium pustulans, infests fig trees in Florida and in the West Indies. C. L. Horn (1931) recommends for its control in the Virgin Islands a 2 per cent paraflin-oil emulsion, applied at intervals of 60 days. J. 
R. Watson (1940) reports that this is about the only insect that bothers figs in Florida. He suggests the use of an oil emulsion in winter.

The latania scale, Aspidiotus lataniae, is found on fig trees in the Madeira Islands, Greece, and Syria. In California, it infests the avocado but not the fig tree.

In 1926 A. Balachowsky reported that the coccid, Morganella longi-spina, was found on a fig tree in the Botanical Garden at Algiers and that the tree was therefore cut down and burned. H. S. Cunningham (1929) found the same insect causing considerable injury to figs in Bermuda, where it is commonly known as "black scale."

The camphor scale, Pseudaonidia duplex, is, according to Cressman (1935), confined largely to southern Louisiana. The females infest the branches, the leaves, and the figs, and they may considerably weaken the tree if it remains unsprayed for several years. The application of an oil emulsion spray during the dormant season is recommended.

Mealy Bugs:Various species of mealy bugs of the genus Pseudo-coccus infest the fig tree and its fruit but seldom cause serious injury. The

\section{Page 182}

Condit

182

The Fig

following species have been noted: in Italy, P. citri by E. Malenotti (1928) ; P. citri in the Crimea by M. P. Umnov (1940) ; in California, P. citrophilus by Clausen (1915) and P. longispinus by E. O. Essig (1914); in South Africa, P. filamentosus by Brain (1929) ; in England, P. ma-ritimus by E. E. Green (1928); in J apan, P. matsumotoi by H. Shi-raiwa (1935) ; and in the Hawaiian Islands, P. nipae by H. T. Osborn (1938).

Leaf Feeders:Insects which feed upon the foliage of fig trees are mostly of local importance. The psyllid, Trioza buxtoni, was described by F. Laing in 1924 as a new species in Palestine. It causes formation of galls and at times entirely destroys many of the leaves. Another psyllid, Homotoma ftcus, is reported by F. B. Boselli (1928) as very common on both edible figs and caprings in Italy; it feeds on the lower surface of leaves during the summer but is not regarded as harmful. In Louisiana, O. W. Rosewell (1920) found nymphs and adults of Anasa tristis feeding on leaves and fruit of the fig tree. 
There are some beetles which attack fig leaves. T. B. Fletcher (1916) reports finding the rutelid beetles, Adoretus versutus and $\mathrm{A}$. horticola, on fig leaves at Pusa, India. In Ceylon, according to J. C. Hutson (1937), the leaf-eating beetles Micro trichia sp. and Apogonia sp. occur on the fig. Two chrysomelids are reported on fig leaves in J apan, one, Morphosphaeria japonica by S. Murakami (1936), the other, Nodostoma julvipes by H. Yuasa (1934). The weevil, Otiorhynchus cribricollis, nibbles fig leaves in South Australia according to A. M. Lea (1927). The larvae of Galeruca semipullata feed on the under surfaces of fig leaves and completely skeletonize them in New South Wales. \{See McKeown, 1942.)

Some lepidopterous larvae include fig leaves as one of their food materials. A tineid leaf miner, Acrocercops ficuvorella, was described by M. Yasaki (1926) as a new species on the fig in J apan. According to A. Da Matta (1927), caterpillars of the syntomid, Delphyre rufiventris, cause considerable injury to foliage of the fig in Brazil. A. Hempel (1920) reports that at Sao Paulo Ituna ilione has become a pest of the foliage of the cultivated fig.

Larvae of the moth, Hemerophila nemorana, feed on fig leaves in several Mediterranean fig districts. According to A. M. Iliinsky (1916), this species is found in Kakhetia only in places where fig trees are grown. Picard (1914) reports that the caterpillars feed on the undersides of fig leaves, often leaving the upper epidermis intact. They also attack the fruits, and injure them more seriously than they do the foliage. In Algeria, states Trabut (1923), the larvae of Hemerophila live under a web on the lower surface of the leaf but are generally kept in check by natural enemies.

A liparid moth, Ocnerogyia amanda, was reported by P. A. Buxton (1920) to be destructive in Mesopotamia. The larvae devoured all the fig leaves completely with the exception of the large midribs. Since they are night feeders, remaining concealed among leaves on the ground during the daytime, banding the trunk is one method of prevention. Y. Ramachandra

\section{Page 183}

\section{Chapter XX}

\section{3}

Insects and Pests

Rao (1922) reports only sporadic damage by this species near Baghdad. Hugh Scott (1929) found some fig trees in the same district badly attacked but others near by were practically free from injury. Broods succeed one another throughout the summer. 
Leaves of the fig are devoured by caterpillars of the sphinx moth, Pachylia ficus, in Pernambuco, Brazil, according to Louis Pyenson (1938).

\section{FRESH-FRUIT INSECTS}

Fruit Flies:The Mediterranean fruit fly, Ceratitis capitata, infests the fig and other soft fruits. H. J. Quayle (1914) found that in Sicily figs were not infested to so great an extent as peaches, possibly because most of the figs were picked for drying while still firm. In Almeria Province, Spain, according to a report by M. D. Leonard (1925), figs in a susceptible stage of ripeness were commonly infested with an average of four or five larvae to each fallen fruit. This fruit fly attacks figs from April to J uly in the J ordan Valley, states A. Grunberg (1938). Figs in Hawaii also are generally infested. \{See E. A. Back and G. E. Pejmberton, 1918.)

The fig is listed by E. W. R^ust (1918) as one of the food plants of Anastrepha jratercuius in northern Argentina.

Larvae of Dacus zonatus infest figs at Pusa, India, according to M. Bezzi (1916).

The "mosca nera del fico," or "black fly of the fig/ $\backslash$ ' Lonchaea aristella, is a primary pest of fresh figs in the Old World. According to L. Savas-tano (1915, 1917), this species, indigenous to North Africa, is called "black fly" to distinguish it from the Mediterranean fruit fly. An excellent account of Lonchaea is given by F. Silvestri (1917) who adds Corfu, Spain, and Portugal to the list of countries where it has been found. There are six generations in a single season. The caprifig is the preferred host but the edible fig suffers most severely; in some instances over 50 per cent of the inflorescences have fallen because of the attacks of this fly. Lonchaea was recorded by $R$. Poutiers (1921) in the vicinity of Mentone, France. According to N. Sevket (1934), this fly is the chief pest of figs in Asiatic Turkey. In July, 1933, about 30 per cent of the edible figs and caprifigs were infested, with a 25 per cent loss of crop. According to Umnov (1940), this species is not found in the Crimea.

In 1917, Silvestri found another fly, Oscinosoma discretum, infesting ripe profichi and mammoni caprifigs in the vicinity of Naples. The larvae feed on the decomposing flowers.

Coleopterous Fruit Pests: There are a few species of beetles which sometimes seriously injure fig fruits. Two species of Cotinis, C. nitida in southeastern, and C, texana in southwestern United States, are so destructive of figs that each is commonly designated "The fig eater." Experiments reported by J. J. Davis and P. Luginbill (1921) from North Carolina tend to show that adults of C. nitida "are not attracted to figs until the odor is detectablein other words until the fruit is bruised." According 
Condit

184

The Fig

to A. A. Nichol (1935), soft-skinned fruits are severely injured or totally destroyed in Arizona by the adults of the fig beetle: "Where it is necessary for them to make the initial effort on a whole-skinned fruit they effect entrance by means of the clypeal horn. The adult mouth parts are weak and unsuitable for tearing the epidermis. The beetle therefore punctures the skin with this horn and raises up a flap of skin until the tenderer part below is exposed/ $\backslash$ ' As larvae feed on decaying vegetable matter, effective control is obtained by a thorough cleaning of corrals and haystack bottoms from February to April. No practical methods of controlling adults were found in Arizona. Cotinis texana was first found in California in 1934, at Riverside. The following year beetles were plentiful near Redlands, feeding oft figs previously pecked by birds. \{See D. B. Mackie 1934, 1935.)

C. W. Howard (1908) reported the discovery in the Transvaal of a fig curculio, probably Metatyges turritus. It had previously been found in Natal.

J. L. Froggatt (1924) stated that in Queensland "a cerambycid, Monohammus mixtus, has been reported destroying the young fruit.,,

In 1923 R. W. Jack announced that in Rhodesia, a fig weevil, Omo-phorus stomachosus, is "probably the commonest cause of stung figs." Adults not only feed on fruit but gnaw the bark of twigs. G. C. Haines (1927) added the information that "the infested portions of figs are conspicuous as blackened spots plugged with gummy matter, and nearly ripe figs, where the egg pits are fresh, may be eaten if these are cut out."

IIThe dried-fruit beetle, Carpophilus hemipterus, is a cosmopolitan species which is a greater pest of ripening figs than of fully dried fruit. Hagan (1929a) found this beetle attacking sound figs as readily as split ones and added that "the eye of the Smyrna fruit is large and open, permitting easy access to the interior." He reported from 2 to 5 larvae in infested figs early in the season, and in one instance 21 lanvae were counted in a single fig. Other species of Carpophilus infest figs, $\mathrm{C}$. hemipterus being the most important. C. dimidiatus is called "sour bug" in Texas because it attacks unripe figs and causes souring.

The life history and habits of the dried-fruit beetle have been recounted by $\mathrm{E}$. O. Essig (1915), by Simmons et al. (1931), and by Quayle (1938). The 
relation of this beetle to the problem of smut and of souring in figs is discussed in chapter XIX.

Larvae and adults of Carpophilus are present in most fig orchards from the middle of J une to the middle of November. "Stick-tight" figs, which remain on the trees all winter, harbor some beetles, but most of the adults overwinter in places where there are accumulations of decaying fruits, or in dried fruit warehouses. The species commonly overwinters in the soil under fig trees, for the most part in the larval stage but also as pupae. The duration of the life cycle depends chiefly upon temperature. In summer, successive generations of beetles develop about every three weeks; the population may, therefore, increase prodigiously during the fig season.

The problem of control of Carpophilus has not been solved. \' Elimination of breeding places is a logical procedure. Since figs with closed or sealed eyes can not be entered by the beetle, the possibility of artificially

\section{Page 185}

\section{Chapter XX}

185

Insects and Pests

sealing figs on the tree has been considered. Simmons et al. (1933) sprayed trees with a 1-to-I mixture of water and pumicite, but only 7 per cent of the figs on the sprayed trees were found to be sealed. L. A. Strong (1935) reported better success with experiments in which a sealing mixture of glucose and gelatin was applied to Adriatic trees with a paint sprayer. Extensive trapping of adult dried-fruit beetles has been carried on. \{See Simmons et al., 1931.) The trap consists of a tin pail with a perforated cover and a bait of fermenting peaches in the bottom. The use of microorganisms for the production of odors attractive to the dried-fruit beetle is discussed by J. D. Wildman (1933). Beetles may be caught in traps in immense numbers, but trapping does not reduce the population sufficiently to effect control. The traps are most effective when used in March, April, and May, before any figs have ripened.

Small darkling ground beetles, chiefly Blapstinus rufipes, sometimes injure ripe figs on the tree but usually attack drying or dried figs on the ground. For control, Simmons suggests the use of a poisoned mash similar to that used for grasshoppers.

Lepidopterous Fruit Pests: Adult butterflies and moths sometimes injure figs. Stansel and Wyche (1932) record the fact that Alabama argillacea is often 
called the "fig moth" in Texas since the moths sometimes suck the juices from the ripening fruit until it becomes a dried pulp. According to D. Gunn (1929), three species of fruit-piercing moths attack fruits such as the fig and extract the juice. In Japan, G. Ojima (1919) found that the larva of a moth, Margaronia brizoalis, by boring into figs by way of the stalk, was deforming the fruit and causing it to drop. McKeown (1942) states that the larvae of Limnaecia delicrosella have been recorded as feeding on figs, apparently in Australia. According to T. B. Fletcher (1920), the caterpillars of Stathmopoda sycastis damage edible figs in the Peshawar district of India.

Miscellaneous Fruit Pests:Ants are occasionally found infesting figs. Hagan (1929a) states that Formicomus ionicus is found in the Smyrna fig district, "constantly and in abundance upon the leaves and ripening fruit. It is a far more active insect than Carpophilus and individuals repeatedly have been seen entering several figs in quick succession." Hagan regarded this species of ant as a prolific disseminator of smut spores and thought it probably of more economic importance in Turkey than Carpophilus. Wilmon Newell and T. C. Barber (1913) found the Argentine ant was doing considerable damage to figs in Louisiana by boring through the ripening fruit or by entering through the eye and tunneling the interior.

C. A. Isaakides (1930) stated that in Greece two species of locusts attacked summer fruits, especially figs.

C. K. Brain (1929) described Gubela bellicosa as a small, smoky-colored jassid which sucked sap from young figs.

Vinegar flies, mostly Drosophila ampelophila, are attracted to ripening figs and deposit eggs within the eye. Wormy figs result. The adult flies, like Carpophilus, transmit yeasts that cause souring.

\section{Page 186}

\section{Gondit}

186

The Fig

Thrips: Thrips seldom attack the foliage of fig trees but they do infest the fruit. The fig is listed by S. F. Bailey (1938) as a host of the bean thrips, Hercothrips jasciatus. In his study of thrips as carriers of fig-decaying organisms, H. N. Hansen (1929) found that 20 per cent of the figs examined were infested with thrips, specimens of which were identified as Thrips tabaci and a species of Frankliniella, probably F. californica. Other species of thrips found on figs are recorded by Simmons et al. (1931). In 1930 D. Moulton 
described Graphidothrips stuardoi as a new genus and species doing considerable damage to figs in Chile. It attacks the leaves and scars the surface of the fruit. On small trees this thrips can be controlled by spraying with water, but on large trees, this simple method of control is impractical.

\section{DRIED-FRUIT INSECTS}

The importance of insects which commonly infest dried figs is out of all proportion to their number, for unless they are controlled, any one of them may render stored figs unfit for human consumption. Insects which infest dried figs are treated by Simmons et al. (1931), by Boselli (1933), by E. G. Linsley and A. E. Michelbacher (1943), and by H. C. Dono-hoe etal. (1943).

There are two species of Ephestia which commonly attack figs. The fig moth, E. cautella, was found by E. G. Smyth (1911) to be the principal cause for wormy figs in the Smyrna fig district. Only on rare occasions were the larvae found in ripe figs on the tree. The moths were found by dozens hovering over "serghi" in the drying yard at night and depositing eggs on the figs. The average infestation for all figs not remaining over three nights on the "serghi" was 37 per cent. Infestation also occurred in piles of figs awaiting transportation to Smyrna. A description of the fig moth and its life history in the United States is contributed by F. H. Chittenden (1911).

The other species of Ephestia which attacks figs is E. figulilella, commonly known as the "raisin moth." H. C. Donohoe and D. F. Barnes (1934) have found a number of field hosts of the raisin moth which provide for the entire annual cycle of the insect in the field. Its increase in waste fruits, such as mulberries, prunes, and peaches, largely explains its usual abundance during the harvesting and drying of the various dried fruits. Damage by the larvae consists of feeding, largely on the surface of the fruits, and of deposition of fecal pellets and silken webbing.

The Indian-meal moth, Plodia interpunctella, is a cosmopolitan species which attacks a wide range of stored foods and dried fruits. The moths, usually found in dark store rooms, are chiefly night fliers and lay their eggs singly or in clusters on the surface of fruits. The newly hatched larvae usually work their way into dried figs where they construct small cocoon-like structures made of pellets of their excrement webbed together. The full-grown larvae crawl outside their food material to spin their cocoons and to pupate. Larvae of both Plodia and Ephestia are partially controlled by parasites.

The following two insects are of minor importance in or on dried figs. Adults of Vitula serratilineella, designated the "dried-fruit moth," are 


\section{Chapter XX}

187

Insects and Pests

nearly twice as large as those of the Indian-meal moth. There may be as many as three generations in one year in unheated store rooms in California. The saw-toothed grain beetle, Oryzaephilus sUrinamensis, infests figs and other dried fruits only after prolonged storage. It is seldom found on ranches or in growersl' deliveries of figs.

Control:In the control of dried-fig insects the proverbial statement, "an ounce of prevention is worth a pound of cure," is especially applicable. Control begins in the orchard and its vicinity by the elimination, as far as possible, of breeding places of the various insects involved. Five recommendations made in 1933 by Perez Simmons et al. regarding insect control may be summarized as follows: $\{1$ ) Pick up and dispose of first-crop figs. If these figs are plowed under, they serve as a source of moths even after the harvest of the main crop is completed. (2) Gather figs as frequently as possible, at least once a week. (3) Dry the figs under covers of shade cloth. The use of such cloth was found by H. C. Donohoe et al. (1934, 1937) largely to prevent egg laying by Ephestia moths. (4) Cover all figs in stacks of trays and in boxes with shade cloth so supported that it will not be in contact with the fruit. (5) Deliver figs to buyer promptly, or protect them immediately after drying by fumigation and insect-tight storage.

Suggestions sent to growers by the California Fig Institute in 1940 state:

Dried figs should be fumigated after they have been picked and before they are placed in the dry yard. They should be fumigated again after drying and held in fumigable storage until delivery to the packer. Dried figs should remain in fumigation for at least twenty-four hours and if held in storage for more than two weeks, they should be refumigated at the end of each twoweek period.

An account of fumigation for the control of insects attacking dried fruits and of the fumigants used is given by Linsley and Michelbacher (1943). For most growers, chloropicrin is the safest and most effective fumigating material. The dosage rate is one pound per 1000 cubic feet. Fumigation chambers built especially for the purpose are being used by many California fig growers. Methyl bromide is also a very effective fumi-gant for figs. Because of its low boiling point, $400 \mathrm{~F}$., it can be used at lower temperatures than most fumigants. It is more toxic to human beings than chloropicrin and should, therefore, be used only by experienced persons. Instructions for fumigation are obtainable from federal and state agents, from the Dried Fruit Association, San Francisco, and from the California Fig Institute, Fresno. 
In 1932 Harry Stiner published an account of a trip that he made to Smyrna in order to instruct Turkish growers and packers on methods of fumigation. In drying yards near the orchards, he utilized cubical "baby" fumigators of one meter outside dimensions. In a Smyrna packing house he installed large vacuum fumigators and employed as a fumigant a material known as "E.C. M.," a combination of ethylene dichloride, three parts, and carbon tetrachloride, one part, by weight.

\section{Bibliography}

\section{Page 188}

\section{BIBLIOGRAPHY}

Aaronsohn, Aaron, 1910: Agricultural and botanical explorations in Palestine. U. S.

Dept Agr. Bur. PL Ind. Bui. 180: 7-64. (Figs, p. 21-22.) Abbott, Ouida, 1931: General properties of some tropical and subtropical fruits of

Florida. Fla. Agr. Exp. Sta. Bui. 237: 1-32. (Fig, p. 5.) Acosta, J oseph de, 1590: Historia natural y moral de las Indias. Seville. Adanson, Michel, 1763: Families des plantes. 2 Vols. Vincent, Paris. (F. carica,

Vol. 1:116-121.) Affleck, Thomas, 1842: Letter. Amer. Agr. 1:153. Aigremont, 1908: Volkserotik und Pflanzenwelt. S. Trensinger, Halle. (Feige, Vol.

1:74-78.) Albertus Magnus (1193-1280), 1867: De vegetabilibus libri VII, historiae naturalis.

G. Reimeri, Berolini. Algaida, General Conde de la, 1916: Las higueras en la hacienda de Pino real. Im-

prenta Alemana, Madrid. Anagnostopoulos, P. Th., 1939: The enemies of fruit trees. (In Greek.) Athens. Anderson, W. S., 1931: Figs. Miss. Agr. Exp. Sta. Bui. 297: 10. Anonymous, 1898: Customs tariffs of the United Kingdom 1800 to 1897. Great Brit-tain Parliament House of Com. Sess. Papers 85.

-----, 1921: A woman leads in the fight on fig smut. Assoc. Grower 2(11) : 5. Nov.

------, 1935: Foil solves fig problem. Food Ind. 7: 83.

------, 1937: And they stay "softenized." Food Ind. 9:659. 
Turkey.

U. S. Tariff Com., Washington, D. C. ------, 1943: Agricultural Prorate Actrevised to August 4, 1943. Calif. State Dept.

of Agr., Sacramento. Arendt, N. K., 1939: Results of the work on fig trees at Nikita. Lenin Acad. Agr.

Sci. Vol. 14(4) : 1-40. (Abs. in: Hort. Abs. 10(2) : 122.) Aristophanes (448385 B.C.), 1910: The Acharnians. Translation by B. B. Rogers.

George Bell \& Sons, London.

------, 1930: The birds. Translation by B. B. Rogers. George Bell \& Sons, London.

Aristotle (384-322 B. C), 1878: History of animals. Bell and Sons, London. Translated by Richard Cresswell. Arnaud, G. et Madeleine Arnaud, 1931: Traite de pathologie vegetale. Paul Leche-

valier et Fils, Paris. Athenaeus (A.D. 228), 1927: The Deipnosophists. Translation by C. B. Gulick.

7 Vols. Harvard Univ. Press, Cambridge. Atwater, W. O., and C. D. Woods, 1896: The chemical composition of American food

materials. U. S. Dept. Agr. Office Exp. Sta. Bui. 28:1-47. Rev. ed. by W. O.

Atwater and A. P. Bryant, 1906:1-87.

Back, E. A., and C. E. Pemberton, 1918: The Mediterranean fruit fly in Hawaii.

U. S. Dept Agr. Bui. 536:1-118. Badie, Mohamed A., and Ahmed Ghamrawy, 1931: The growing of figs. Egypt

Min. of Agr. Hort. Sect. Giza Booklet 2:1-29. Bailey, S. F., 1938: Thrips of economic importance in California. Calif. Agr. Exp.

Sta. Circ. 346:1-77. Baker, E. E., and E. M. Mrak, 1938: Yeasts associated with the "sugaring" of dried

prunes and figs. Jour. Bact. 36:317. Baker, E. W., 1939: The fig mite and other mites of the fig tree. Calif. Dept. Agr.

Bui. 28:266-275. Balachowsky, A., 1926: Note sur un Coccide de la faune neotropicale recemment acclimate et nuisible au figuier en Algerie. Soc. $d$ 
I'Hist. Nat. de II'Afrique du Nord,

Bui. 17: 63-69. (See Rev. Appl. Ent. 14: 457.) ------, 1929: Biologie d I'Hesperophanes fasciculatus Fald., Cerambycide nuisible au

figuier cultive en Afrique du Nord. Rev. de Path. Veg. et $d$ ' 'Ent. Agr. de France

16:156-159. (See Rev. Appl. Ent. 17: 540.) Balachowsky, A., et L. Mesnil, 1935: Les insectes nuisibles aux plantes cultivees.

Etabl. Busson, Paris.

\section{Page 189}

The Fig 189 Bibliography

Balfour, E. G., 1885: The cyclopedia of India. B. Quaritch, London.

Ballou, C. H., 1936: Insect notes from Costa Rica in 1934, 1935. U. S. Dept. Agr.

Bur. Ent and PL Quar. Ins. Pest Surv. 15:163-212; 16:437-497. Barger, W. R., 1941: Effect of cold storage conditions on the keeping of dried fruit.

West. Canner and Packer 33(6) : 47-50. May. Barron, A. F., 1868a: Grosse Verte fig. Florist and Pom. 3rd ser. 1: 56-57.

------, 1868\&: De la Madeleine fig. Florist and Pom. 3rd ser. 1:179-181.

-----, 1868c: A selection of choice figs. Florist and Pom. 3rd ser. 1: 211-213.

-----, 1869: Fig Col di Signora Blanca Panachee. Florist and Pom. 3rd ser. 2: 145.

------, 1871: Royal Vineyard fig. Florist and Pom. 3rd ser. 4: 49-50.

Bartram, J ohn, 1765-1766: Diary of a journey. In: Amer. Phil. Soc. Trans. 32:1-

120. Annotated by Francis Harper. 1942. Bartram, William, 1791: Travels. 1940 edition. The Facsimile Library, New York. Bauhin, Kaspar, 1623: Pinax theatri botanici. Ludovici Regis, Basiliae. Beckett, Edwin, ''1941: Fruits for the home garden. N. Y. Bot. Gard. J our. 42:133-

140. Benavet, J., 1922: Figs as raw material for alcohol manufacture and as a 
stock food.

Agriculture 6: 354. \{See Chem. Abs. 17: 2462.) ^ Benedict, M. R., 1933: The Merced Irrigation District, an economic survey. $133 \mathrm{p}$.

Giannini Foundation Agr. Econ., Berkeley. Benson, Martin, 1886: Bensonl's guide to fig culture in the open ground at the north.

Swanwick, Illinois. Bernard, Mrs. W. B., 1866: Our common fruits. F. Warne, London. (Fig, p. 233-

251.) Bessey, E. A., 1911: Root-knot and its control. U. S. Dept. Agr. Bur. PL Ind. Bui.

217:7-89. Bethel, Slingsby, 1691: The providence of God. R. Baldwin, London. Betts, Edwin M., 1944: Thomas J effersonl's garden book. Amer. Phil. Soc., Philadelphia. Beverley, G. W., 1939: Re-working fig trees. Agr. Gaz. N. S. Wales 50:324-328. Bezzi, M., 1916: On the fruit flies of the genus Dacus occurring in India, Burma, and

Ceylon. Bui. Ent. Res. 7: 99-121. Bioletti, F. T. 1938: Outline of ampelography for the vinifera grapes in California.

Hilgardia 11:227-293. Blair, R. E., 1914: Seedling figs. U. S. Dept. Agr. Bur. PL Ind. Work Yuma Exp.

Farm in 1913:11-12. -----, 1915: Fig hybrids at Yuma. U. S. Dept. Agr. Bur. PL Ind. Western Irr. Agr.

Circ. 7:19. -----, 1918: Seedling figs. U. S. Dept. Agr. Bur. PL Ind. Western Irr. Agr. Circ.

25:38. ------, 1920: Fig seedlings. U. S. Dept. Agr. Bur. PL Ind. Western Irr. Agr. Circ.

75:44. Bobone, Alvaro, 1932: Contribui^ao para o estudo taxonomico da especie, Ficus carica.

Lisboa. Bodkin, G. E., 1927: The fig wax scale in Palestine. Bui. Ent. Res. 17:259-263. Boetticher, Karl, 1856: Der Baumkultus der Hellenen.

Weidmann, Berlin. (Feige,

p. 128, 286, 437.) Boissier, Edmond, 1867-1884: Flora orientalis. H. Georg, Basileae. Bolton, H. E., 1936: The rim of Christendom. The Macmillan Co., New York. Bonavia, E., 1894: Flora of the Assyrian monuments. A. Constable and Co., Westminster. Bondar, G., 1913: Injurious insects in Brazil. [Sao

Paulo] Bol. de Agr. 14:28-42. 
\{See Exp. Sta. Rec. 30: 454.) ------, 1920: Como combater a lagarta dos galhos da figueira. Chacaras e Quintaes

21:108-109. \{See Rev. Appl. Ent. 8: 211.) ------, 1923: Notas biologicas sobre alguns buprestideos brasileiros do genero Colobo-

gaster Solier. Rev. Mus. Paul. [Sao Paulo] 13: 1267-1276. \{See Rev. Appl. Ent.

12:352.) Borde, Andrew, 1547: The first boke of the introduction of knowledge. Early English Text Soc, London. Borg, J., 1922: Cultivation and diseases of fruit trees in the Maltese Islands. Gov. Pr.

Office, Malta. (Fig, p. 126-148.) Boselli, F. B., 1928: Contributo alia conoscenza della Psylla del fico. Portici R.

Scuola Super, di Agr. Lab. Zool. Gen. e Agr. Bol. 21:218-251. \{See Rev. Appl.

Ent. 17:458.)

\section{Page 190}

Condit 190 The Fig

\&------, 1933: Contro VEphestia cautella (farfalla dei fichi secchi). Picentino [Salerno]

89: 9-23. (See Rev. Appl. Ent. 21: 429.)

Boyd, Mary S., 1911: Fortunate isles. F. A. Stokes Co., New York.

Brain, C. K., 1920: The Coccidae of South Africa. Bui. Ent. Res. 9:107-139, 197-239; 10:95-128; 11:1-41.

+------, 1929: Insect pests and their control in South Africa. Nasionale pers Beperk,

Cape Town.

Brann, Frank R., 1923: Model processing plant at Dinuba. Calif. Cult. 60:468.

Brickell, J ohn, 1737: The natural history of North Carolina. James Carson, Dublin.

Brierly, W. B., 1916: Botrytis cinerea, a disease attacking the shoots and fruit 
of fig trees in England. Kew Roy. Bot. Gard. Bui. Misc. Inf. 9:225-229.

Brooks, C, and L. P. McColloch, 1938: Spotting of figs on the market. Jour. Agr. Res. 56:473-488.

Brooks, C, et al., 1936: Transit and storage diseases of fruits and vegetables as affected by initial carbon dioxide treatments. U. S. Dept. Agr. Tech. Bui. 519: 1-24.

Brookshaw, George, 1812: Pomona Britannica. Typis Bensley, London.

Brown, W. P., 1918: Care of Merced figs. Pacific Rural Press 95: 429.

Bruschi, Diana, 1907: Sopra alcuni presami o chimasi vegetali. R. Accad. Naz. dei Lincei. Atti Ser. 5, 16:360-371.

Budd, J. L., and N. E. Hansen, 1909: American horticultural manual. J ohn Wiley and Sons, New York.

Bunyard, E. A., 1934: Cultivation of the fig. Roy. Hort. Soc. J our. 59: 61-67.

Burbank, Luther, 1914-15: His methods and discoveries and their practical application. 12 Vols. L. Burbank Press, New York. (Fig, Vol. 4: 297.)

Burger, O. F., 1923: Fig diseases. Fla. Agr. Exp. Sta. Ann. Rpt. for the year ending J une 30, 1923: 79R-80R.

Burr, Aaron, 1838: The private journal of Aaron Burr. 2 Vols. Ed. by Matthew L. Davis, New York.

Buscalioni, L., e G. Grandi, 1936: Ll'evoluzione dei ricettacoli del F. carica in rap-porto con II'insetto pronubo. R. Accad. delle Sci. dellTst. Bologna Ser. 9, T. 3:1-16.

suoi rapporti

1938: II Ficus carica L., la sua biologia, la sua coltivazione e i

con II 'insetto pronubo. Bologna R. Univ. 1st. di Ent. Bol. 10: 223-280.

Butterfield, H. M., 1938: Pioneers in Californial's fig industry. Blue Anchor 15 (1) : 16-18. Jan.

Buxton, P. A., 1920: A liparid moth destructive to figs in Mesopotamia. Bui. Ent. Res. 11:181-186.

Caldis, P. D., 1925: A rot of the Smyrna fig in California. Science 62:161-162. 
-----, 1926: Souring and internal rot of the fig. Pacific Rural Press 111: 500.

-----, 1927: Etiology and transmission of endosepsis (internal rot) of the fig. Hil-

gardia 2: 287-328. ------, 1930: Souring of figs by yeasts and the transmission of the disease by insects.

J our. Agr. Res. 40:1031-1051. California Fig Institute, 1939: Dried fig recipes. Calif. Fig Inst., Fresno. Calvtno, M., 1912: Cultivo de la morera y la higuera. [Mex.] Estac. Agr. Cent.

Bol. 73:1-33. Carles, P., 1891: Characteristics of fig wine. (Transl. title.) [Paris] Acad, des Sci.

Compt. Rend. 112:811.

------, 1916: Fig wine. Bol. Chim. Farm. 55:135. (See Chem. Abs. 10:1903.)

Cato, Marcus P. (234-149 B.C.), 1933: Cato the Censor on farming. Translation by

Ernest Brehaut. Columbia Univ. Press, New York. Cavara, F., 1905: Bacteriosi del fico. Accad. Gioenia di Sci. Nat. Atti 18, Mem. 14:

1-18. Cavolini, F., 1782: Memoria per servire alia storia compiuta del fico e della pro-

ficazione relativamente al Regno di Napoli. Opuscoli Scelti sulla Scienze e sulla

Arti, Milano 5:219-249. Celi, G., 1907: Ricerche sulla biologia e filogenesi del fico. R. 1st. dTncoragg. di

Napoli Atti, 6 ser., 59: 541-654. Celsus, Aulus C, 1935-I'38: De medicina. Transl. by W. G. Spencer. 3 Vols. Wm.

Heinemann, London. First ed. 1549. Chace, E. M., 1940: Letter from E. M. Chace, Bureau of Agr. Chem. and Eng., U. S.

Dept. Agr., March 25, 1940.

\section{Page 191}

The Fig 
191

Bibliography

Chace, E. M., et aL, 1941: Preservation of fruits and vegetables by commercial dehydration. U. S. Dept. Agr. Circ. 619:1-46. Chamberlain, J ohn W., 1919: Figs in the north. Garden Mag. 29:238. Chandler, W. H., 1925: Fruit growing. Houghton Mifflin Co., Boston.

-----, 1934: Dry-matter residue of trees. Amer. Soc. Hort. Sci. Proc. 31:39-56.

Chandler, W. H., et aL, 1937: Chilling requirements for opening of buds on deciduous orchard trees. Calif. Agr. Exp. Sta. Bui. 611:1-63. Chatfield, Charlotte, and Laura McLaughlin, 1928: Proximate composition of

fresh fruits. U. S. Dept. Agr. Circ. 50:1-19. Cheema, G. S., 1941: Summary of work done at Poona. Bombay Dept. Agr. Ann.

Rpt. 1939-40:245-249. Chittenden, F. H., 1911: The fig moth. U. S. Dept. Agr. Bur. Ent. Bui. 104:9-40. Chodat, R., and E. Rouge, 1906: La sycochymase ou le labferment du Ficus Carica.

Centbl. fur Bakt. II, 16:1-9. Chomel, Pierre, 1782: Abrege de II'histoire des plantes usuelles. Paris. Christie, A. W., and Mrs. I. J. Condit, 1926: Processing and packing dried figs.

West. Canner and Packer 17(9) : 19-21. Jan. Clark, George, 1831: Oiling figs. So. Agriculturist 4: 387.

Clausen, C. P., 1915: Mealy bugs of citrus trees. Calif. Agr. Exp. Sta. Bui. 258: $19-48$.

------, 1931: Insects injurious to agriculture in Japan. U. S. Dept. Agr. Cir. 168:

1-103. Coit, J. E., 1921: The splitting and souring of figs. Rural World 24: 5. Jan. 15. Colby, G. E., 1894: Analyses of figs. Calif. Agr. Exp. Sta. Rpt. 18921893: 226-235.

------, 1902: Smyrna figs. Calif. Agr. Exp. Sta. Rpt. 1898-1901:242.

Coleman, W., 1880: Brown Turkey fig. Florist and Pom. 1880:145.

Coleridge, S. T., 1884: Coleridge works. Harper and Bros., New York. (Sycophant,

Vol. 3:286.) Collins, J. L., 1919: A case of chimera in a fig. J our. Hered. 10: 6- 
8, fig. 3-4. Columella, L. Junius M. (1st Century A. D.), 1745: Of husbandrytranslation by

M. C. Curtius. A. Miller, London. Conct, Giulio, 1924: Alcune osservazioni sul Ficus carica nel Trentino. Bol. Chim.

Farm. Milano 63: 305-311. Condit, I ra J ., 1918a: How the female Blastophaga works. Calif. Comn. Hort. Mo. Bui. 7:538-540.

-----, 19186: Some causes of the souring and splitting of figs. Fig and Olive Jour. 3

(5) : 11, 12, Oct.; (9) : 13, 14, 15, 16, Feb. 1919. 1919: Bits of fig history in California. Calif. Comn. Hort. Mo. Bui. 8:260-265. 1920a: Fig cuttings and their proper treatment. Fig and Olive J our. 4(8) : 11. Jan. 19206: Selection of fig cuttings. Calif. Dept. Agr. Mo. Bui. 9:183-187. 1920c: Smyrna fig. Assoc. Grower 1(6) : 11, 12. Aug. 1920a*: White Adriatic fig. Assoc. Grower 1(7) : 10. Sept. 1920c: The Kadota fig. Assoc. Grower 1(8) : 18, 35. Oct. 1920/: Caprifigs and caprification. Calif. Agr. Exp. Sta. Bui. 319:341-375. Reprinted 1922. 1921a: Why our fig trees are dying. Farm Bureau Rev., 2nd. p. 15, 29. 19216: Mission fig. Assoc. Grower 2(1) : 27. Jan. 1922a: The Stanford Smyrna fig. Assoc. Grower 4(3) : 6, 20. Oct. 19226: A new fig food. The Fruitman 2(4) : 8. April. 1923: Top working fig trees. Assoc. Grower 5(3) : 1415. March. 1924a: The fig industry of the Old World. Smyrna. Assoc. Grower 6 (8) : 14-15,27. Aug. 19246: Greece. Assoc. Grower 6(9-10) : 14-15, 22. SeptOct. 1924c: Algeria. Assoc. Grower 6(11) : 10, 17, 26. Nov. 19240*: Italy. Assoc. Grower 6(12) : 14-15, 19. Dec. 1925a: The fig industry of Portugal. Calif. Fruit News 71:4, 9. April 11. 19256: The fig industry of Spain. Calif. Fruit News 71: 5, 15, 17, 18. Feb. 21; 71:13. Feb. 28. 1927: The Kadota fig. Calif. Agr. Exp. Sta. Bui. 436:3-42. 1928a: Other fig chimeras. J our. Hered. 19: 49-53. 19286: Fig breeding. J our. Hered. 19: 417-424.

1928c: Chromosome number and morphology in seven species of Ficus. Calif. Univ. Publ. Bot. 11: 233-244.

\section{Page 192}

Condit

192

The Fig Hilgardia 
6:443-481.

-----, 1933: Fig culture in California. Calif. Agr. Ext. Serv. Circ. 77:1-67. Revised Aug. 1941.

------, 1934: Anomalous fig trees. J our. Hered. 25: 497.

------, 1938: Parthenocarpy in the fig. Amer. Soc. Hort. Sci. Proc. 36: 401-404.

------, 1941a: Commercial fig culture (Texas). Pacific Rural Press 141:134.

-----, 19416: The Brunswick (Magnolia) fig. Amer. Soc. Hort. Sci. Proc. 39:143-

146.

------, 1941c: Fig characteristics useful in the identification of varieties. Hilgardia

14:1-68.

------, 1942: The Croisic (Cordelia) fig. Amer. Soc. Hort. Sci. Proc. 40:255-258.

------, 1943: The fig-variety character, flattened neck. Amer. Soc. Hort. Sci. Proc.

42:255-258.

------, 1944: San Piero, the Brown Turkey fig of California. Amer. Soc. Hort. Sci,

Proc. 44:211-214.

Condit, I ra J., and S. E. Flanders, 1945: "Gall-flower" of the fig, a misnomer. Science 102:128-130.

Condit, Ira J., and W. T. Horne, 1933: A mosaic of the fig in California. Phytopathology 23:887-896.

------j ------f 1941. Further notes on fig mosaic. Phytopathology 31: 561-563.

------, ------, 1943: Mosaic spots of fig fruits. Phytopathology 33: 719-723.

Condit, Ira J., and H. J. Stevens, 1919: "Die-back" of the fig in California. Calif. Comn. Hort. Mo. Bui. 8:61-63. 
Cook, A. B., 1907: Sycophant. Classical Review 21:133-136.

------, 1914: Zeus, a study in ancient religion. University Press, Cambridge.

Cook, O. F., 1922: Figs with misplaced scales. J our. Hered. 13:122-123.

Cooke, M. C, 1904: Pests of the vinery and stove. Roy. Hort. Soc. Jour. 28:313-337.

Cooley, J. L., 1930: Mulched fig plots. Miss. Agr. Exp. Sta. Bui. 285:32.

Cressman, A. W., 1935: Pests. U. S. Dept. Agr. Farmers|' Bui. 1031:23-27.

Croce, F. M., 1937: Desecacion natural y artificial de frutas y hortalizas. Mendoza (Argentina) Sec. Fomento Agr. e Ind. Bol. 24:3-344. (Higos, p. 103106, 257-258, 305-307.)

Cruess, W. V., 1938a: Commercial fruit and vegetable products. 2nd ed. McGraw-Hill Book Company, Inc., New York.

------, 1938\&: Commercial fig products. Fruit Prod. Jour. 17:337-339, 368369; 18:

39-42.

Cruess, W. V., and W. Y. Fong, 1926: Observations on fruit oxidase. Fruit Prod. Jour. 6:13-15.

Cruess, W. V., and G. L. Marsh, 1941: Utilization of California fruits. Calif. Agr. Exp. Sta. Circ. 349: 1-53.

Cruess, W. V., Hazel Friar, and Clark Sumner, 1942: Experiments on concentrated food bars. Fruit Prod. J our. 21: 359-360.

Cruess, W. V., and J. La Moglia, 1942: Fruit bar for army K ration. Fruit Prod. Jour. 22:13.

Cunningham, H. S., 1929: Report of the Plant Pathologist. Bermuda Dept. Agr. Rpt. 1928:26-28. (See Rev. Appl. Ent. 17: 562.)

Czapek, Friedrich, 1925: Biochemie der Pflanzen. Gustav Fischer, Jena.

Dahlgren, B. E., 1922: Figs. Field Museum Nat. Hist, Chicago, Bot. Leaflet 1:17. Dalziel, J. M., 1937: The useful plants of West Tropical Africa. Crown Agents for

the Colonies, London. Da Matta, A., 1927: Larvas de lepid 'opteros e fungo 
prejudiciaes ao ananaz, manaca,

milho, e a figueira. Sciencia Medica 5:175-179. (See Rev. Appl. Ent. 15:408.) Daniel, Esther P., 1939: Vitamin content of foods. In: U. S. Dept. Agr.

Yearbook

1939:286-295. Dante, Alighieri, 1814: Inferno. Translation by Henry F. Cary. Henry Alte-

mus, Philadelphia. Davey, A. E., and R. E. Smith, 1933: The epidemiology of fig spoilage. Hilgardia

7:523-551. Davidson, Anstruther, 1899: Two unrecorded causes of dermatitis. Ther. Gaz. 3rd

ser. 15:85-86. Davis, J. J ., and P. Luginbill, 1921: The green J une beetle or fig eater. N. C. Agr.

Exp. Sta. Bui. 242:1-35.

\section{Page 193}

The Fig

193

Bibliography

Davis, R. A., 1928: Fruit growing in South Africa. Central News Agency, Johannesburg.

Dawson, L. J., 1919: The production and exportation of Spanish figs. U. S. Dept. Com. Com. Rpts. 174:528-532.

Delassus, M., et al,, 1930: Les ennemis des cultures fruitieres en Algerie. La Typo-Litho, Alger.

Deleanu, N. T., 1916: The peptolytic enzyme of Ficus carica. Bucharest Acad. Romana Sect. Sci. Bui. 4:345-354. (See Chem. Abs. 10:2237.)

DeSeabra, A. F., 1918: Observations sur quelques especes de Cochenilles du Portugal. Soc. Portug. de Sci. Nat. Bui. 8: 72-81. (See Rev. Appl. Ent. 7:6.)

Donohoe, H. C, et al., 1934: Experiments in the exclusion of Ephestia figulilella from drying fruit. Jour. Econ. Ent. 27:1072-1075. 
-----, 1937: The use of shade cloth to exclude the raisin moth from drying fruits. Calif.

Dept. Agr. Bui. 26:205-206.

-----, 1943: Preventing damage to commercial dried fruits by the raisin moth. U. S.

Dept. Agr. Leaflet 236:1-6.

Donohoe, H. C, and D. F. Barnes, 1934: Notes on host materials of Ephestia figulilella. Jour. Econ. Ent. 27:1075-1077.

Doughty, C. M., 1923: Travels in Arabia Deserta. Boni and Liveright, New York.

Drummond, O. A., 1941: Seca dos galhos da figueira. Ceres 3:162-164.

Du Breuil, Alphonse, 1876: Cours dl'arboriculture. 4 Vols. Ed. 7. G. Masson, Paris. (Figuier, Vol. 2:602-630.)

Duhamel du Monceau, Henri L., 1755: Traite des arbres et arbustes qui se culti-vent en France en pleine terre. 2 Vols. Paris.

Earle, F. S., 1897: Fig culture in the Gulf States. U. S. Dept. Agr. Div. Pom. Bui.

5:23-32. Edgerton, C. W., 1911a: Diseases of the fig tree and fruit. La. Agr. Exp. Sta. Bui.

126: 1-20.

------, $191 \mathrm{lb}$ : Two new fig diseases. Phytopathology 1:12-17.

Edson, H. A., and J essie I. Wood, 1937: Branch canker (Macrophoma fici) reported

from Louisiana for the first time. Plant Dis. Rep. Suppl. 103:157. Eisen, Gustav, 1885: Fig culture. Pacific Rural Press 30:126, 138. -----, 1896:

Biological studies on figs, caprifigs, and caprification. Calif. Acad. Sci.

Proc. ser. 2, 5: 897-1001.

-----, 1901: The fig. U. S. Dept. Agr. Div. Pom. Bui. 9:1-317.

-----, 1930: Antique fig beads. Amer. J our. Arch., ser. 2, 34:190-196. 
Elliot, H. S., 1915: Fig growing in Florida. Fla. Dept. Agr. Quart. Bui. 25(4) :

7-14. Reprinted 1925. Elliott, Thomas, 1917: Marketing of fresh figs. Calif. Fig Inst. Proc. 1: 87-90. Escribano y Perez, J ose M., 1884: Pomona de la Provincia de Murcia. Impr. Hijo

de Aguado, Madrid. (Higuera, p. 133-147.) Essig, E. O., 1914: The mealy bugs of California. Calif. Comn. Hort. Mo. Bui. 3:97-

143.

-----, 1915 : The dried-fruit beetle. J our. Econ. Ent. 8: 396-400.

Estelrich, Pedro, 1910: La higuera y su cultivo en Espaiia. 228 p. Libr. Escolar, Palma de Majorca.

Felton, C. C, 1893: Greece, ancient and modern. 2 vols, in 1. Houghton, Mifflin \&

Co., Boston. Ferrari, E., 1912: La coltivazione del fico nel Circondario di Paola (Cosenza). Aci-

reale Ann. R. Staz. Sper. Agrumic. e Fruttic. 1: 141-177. Ferraris, Teodoro, 1926: Trattato di patologia e terapia vegetale. U. Hoepli, Milano. Ferris, G. F., 1938: Atlas of the scale insects of North America. Stanford Univ.

Press. Field, Anna, 1931: Dried fruit vitamins. West. Canner and Packer 23: 39. J uly. Flanders, S. E., 1945: The bisexuality of uniparental Hymenoptera, a function of the

environment. ^ Amer. Nat. 79: 122-141. -----, 1942: The introduction of Physcus testaceous into California. J our. Econ. Ent.

35:290. Fletcher, T. B., 1916: One hundred notes on Indian insects. Pusa Agr. Res. Inst.

59:1-39. (See Rev. Appl. Ent. 4: 438-439.) ------, 1919: Report of the Imperial Entomologist. Pusa Agr. Res. Inst. Sci. Rpts.

1918-19: 86-103. (See Rev. Appl. Ent. 8: 83.) \'\&----, 1920: Life histories of Indian insects: Microlepidoptera. Pusa Dept. Agr. Mem.,

Ent. Ser. 6:1-217. (See Rev. Appl. Ent. 9: 272.) 
Gondit

194

The Fig

Folkard, Richard, 1884: Plant lore, legends, and lyrics. Sampson Low, London. Fong, W. Y., and W. V. Cruess, 1929: The effect of pH value on the inactivation

temperature of fruit oxidase. Plant Physiol. 4: 537-541. Forbes, James G., 1821: Sketches, historical and topographical of the Floridas. C. S.

Van Winkle, New York. Forkner, J. C, 1919a: The fig tree. J. C. Forkner, Fresno.

-----, 1919b: Fig Gardens recipes. Forkner Fig Gardens, Fresno.

------, 1920: Future of fig industry. Fresno Republican, J an. 11: Fig and Olive Jour.

4(9): 5, 6, 7. Feb. Fowler, D. T., 1909: Fig culture in California. Western Empire 12:9. Feb. Fowler, M., 1865: Castle Kennedy fig. J our. Hort. and Cottage Gard. n.s. 8: 449. Frank, Tenney, 1938-1940: An economic survey of ancient Rome. Johns Hopkins

Univ. Press, Baltimore. Fraser, William, 1856: Fig-pie wake. Notes and Queries, 2nd ser., 1:227, 322. Frazer, J. G., 1913: Pausanias|' description of Greece. 6 Vols. Macmillan \& Co.,

London. \{See Vol. 6: 65.)

------, 1920: The magical origin of kings. Macmillan \& Co., London. (Fig, p. 269.)

French, C, 1909: A handbook of the destructive insects of Victoria. Part IV.

Osboldstone and Co., Melbourne. Froggatt, J. L., 1924: Entomological notes. Queensland Agr. Jour. 21:120-123.

Gallesio, Giorgio, 1820: Pomona italiana; fasc. primo, contenente il trattato del fico.

123 p. Capurro, Pisa. Galloway, B. T., 1893: Report of the Chief of the 
Division of Vegetable Pathology.

In: U. S. Dept. Agr. Rpt. of Seer. 1892:215-246. Gandhi, S. R., 1924:

Investigations in fig culture. Bombay Dept. Agr. Bui. 117:

1-27. Garidel, Pierre J ., 1715: Histoire des plantes. J oseph David, Aix. GarinoCanina, E., 1919: Wine made from dried figs. (Transl. title.) Gior. Vinic.

Ital. 45:260. \{See Chem. Abs. 15:3179.) Gasparrini, G., 1845: Ricerche sulla natura del caprifico e del fico, e sulla caprifica-

zione. Accad. delle Sci. Napoli, Rend. 4: 321-412. ------, 1854: in G. Gussone: Enumeratio plantarum vascularium in insula Inarime.

(Ficus, p. 299-305.) Typis Vanni, Napoli. ------, 1863: Sulla maturazione e la qualita dei fichi dei contorni di Napoli. Accad.

Pontaniana, Napoli, Atti 9:99-118. ------, 1865: Nuovo osservazioni su taluni agenti artificiale che accelerano la maturazione del fico. Napoli R. Accad. Sci. Fis. e Mat. Atti 2(21). 16 p. (Transl. in:

J our. Hort. Soc. London, n.s. 2:1-17. 1870.) Gerber, C, 1912a: Le latex du figuier, sue pancreatique vegetal a diastase proteoly-

tique predominante. [Paris] Acad, des Sci. Compt. Rend. 155:56-59. ------, 1912b: Les diastases du latex du figuier. Soc. Bot. de France Bui. 59, Mem.

23:1-48. \{See Chem. Abs. 6: 3107.) Gerber, C, et J. Salkind, 1913: Action physiologique des latex. [Paris] Soc. de

Biol. Compt. Rend. 74:65-66. (See Chem. Abs. 7:1384.) Giddings, N. J., and J essie I. Wood, 1925: Diseases of fruit and nut crops in the

United States in 1924. Plant Dis. Rep. Suppl. 39:1-105. Girard, A., 1898: The composition of fresh fruits. Min. Agr. France Bui. 17:1523-28.

\{See Exp. Sta. Rec. 10:754.) Girola, C. D., 1922: Ganoderma sessile Murrill. (Buenos Aires) Min. Agr. Nacion

Bol. 1922: 236-239. (See Rev. Appl. Mycol. 2:17.) Gois, L. A. de Almeida, 1938: Leveduras seleccionadas para a industria do alcool de

figo. Lisboa Univ. Inst. Sup. Agron. An. 9:49-56. \{See PI. Br. Abs. 10:191.) Gordon, J an and Cora Gordon, 1923: Two vagabonds in Spain. R. M. McBride $\&$

Co., New York. Gould, H. P., 1919: Fig growing in the South Atlantic and Gulf 
States. U. S. Dept.

Agr. Farmersl' Bui. 1031: 1-45. Rev. ed. 1935. Grancini, Pietro, 1938: II cancro del fico da "Phomopsis" Riv. di Patol. Veget.

28:103-114. Grandi, Guido, 1920: Studio morfologico e biologico della Blastophaga psenes.

Portici R. Scuola Super. Agr. Lab. Zool. G+n. e Agr. Bol. 14:63-204.

------, 1923: Gli insetti dei caprifichi. Riv. di Biol. 5 : 69-90.

-----, 1930a: Monografia del gen. Philotrypesis Forst. Bologna R. 1st. Super. Agrar.

Lab. di Ent. Bol. 3: 1-181.

\section{Page 195}

The Fig

195

Bibliography

-----, 1930\&: II Sinoxylon sexdentatum e i cavi telefonici. Soc. Ent. I tal. Bol. 62:

17-19. (See Rev. Appl. Ent. 18:291.) Grasovsky, Asaph, and J oseph Waitz, 1932: Fig growing in Palestine. Palestine

Dept. Agr. and Forests Hort. Leaflet 28: 1-36: Gravenhorst, J. L. C, 1829: Disquisitio de Cynipe psene auctorum, et descriptio

Blastophagae, novi Hymenopterorum generis. Beitr. zur Ent. Schles. Ges., Bres-

lau 1:27-33. Green, E. E., 1928: Observations on British Coccidae. Ent. Mo. Mag. 64:20-31. Grunberg, A., 1938: The Mediterranean fruit-fly in the J ordan Valley. Bui. Ent.

Res. 29:63-76. Guglielmi, G., 1908: Coltivazione industriale del fico nel Leccese. F. Giannini,

Napoli. Gunn, D., 1919: The fig and willow borer. Union So. Africa Dept. Agr. 
Bui. 6:1-22.

(See Rev. Appl. Ent. 8: 69.) ------, 1929: Fruit-piercing moths. Farming in So. Africa 3:1263-1264. (See Rev.

Appl. Ent. 17:351.) ------, 1930: The fig and willow borer. Farming in So. Africa 5:312.

Hadzsits, G. D., 1936: The vera historia of the Palatine ficus Ruminalis. Classical

Phil. 31:305-319. Hagan, H. R., 1929a: The fig-insect situation in the Smyrna fig district. Jour. Econ.

Ent. 22:900-909. ------, 1929b: Fig culture in the Smyrna fig district. Calif. Dept. Agr. Mo. Bui. 18:

491-512. Hahn, F. V., 1931: Vitamin studies. Ztschr. f. Untersuch. der Lebensmtl. 61:369-

411. (See Exp. Sta. Rec. 68: 860.) Haines, G. C, 1927: Entomological notes No. 35. The fig curculio. Farming in So.

Africa 2 (April). (See Rev. Appl. Ent. 16: 304.) Hanoteau, Louis A., et A. Letourneux, 1873: La Kabylie et les coutumes Kabyles.

LTmprim. Nationale, Paris. Hansen, H. N., 1927: Control of internal rot of caprified figs. Phytopathology

17:199-200.

------, 1928: Endosepsis and its control in caprifigs. Phytopathology 18:931938.

------, 1929: Thrips as carriers of fig-decaying organisms. Science 69: 356357.

------, 1943: Fig production practices in war time. Pacific Rural Press 145:136, 137.

Hansen, H. N., and A. E. Davey, 1932: Transmission of smut and molds in figs.

Phytopathology 22:247-252. Harmon, F. N., 1943: Influence of indolebutyric acid on the rooting of grape cuttings.

Amer. Soc. Hort. Sci. Proc. 42:383-388. Harrison, Jane E., 1908: 
Prolegomena to the study of Greek religion. University

Press, Cambridge. Hawes, C. H., 1911: Crete, the forerunner of Greece. Harper and Bros., New York. Heald, F. D., and F. A. Wolf, 1911: New species of Texas fungi. Mycologia 3:

5-22. ------, , 1912: A plant disease survey in the vicinity of San Antonio, Texas. U. S.

Dept. Agr. Bur. PL Ind. Bui. 226:3-112. Hegardt, Cornelius, 1744: Ficus ejusque historia naturalis et medica. 28 p. Upsaliae.

Repr. in Vol. 1 of Linnaeus Amoen. Acad.: 23-54. 1749. Hehn, Victor, 1888: The wanderings of plants and animals. Sonnenschein, Swan,

and Co., London. Heintz, A., 1936: La culture du figuier en Grande Kabylie. Rev. de Bot. Appl. et

d) 'Agr. Trop. 16:1002-1007. Hempel, A., 1920: Um inimigo importante da figueira cultivada. Chacaras e Quin-

taes 21: 373-374. (See Rev. Appl. Ent. 8: 366.) Henderson, George, and Allan Hume, 1873: Lahore to Yarkand. L. Reeve and Co.,

London. Herodotus (484-423 B.C.), 1901: Herodotus, literally translated by Henry Cary.

George Bell, London. Hesiod (8th Cent. B.C.), 1915: Hesiod, Homeric hymns and Homerica. Translation

by Hugh G. Evelyn-White. The Macmillan Co., New York. Hewitt, John F., 1907: Primitive traditional history. J. Parker and Co., London. Hilgard, E. W., 1912: Soils. The Macmillan Co., New York. Hill, John, 1751: A history of plants. Osborne, London. Hodgson, R. W., 1918a: Black smut of figs. Calif. State Comn. Hort. Mo. Bui. 7:

188-189. ------, 19186: A Sterigmatocystis smut of figs. Phytopathology 8: 545-546.

\section{Page 196}

Gondit 
The Fig 46: 5 ,

20. May. ------, 1931: La culture fruitiere en Tunisie. Soc. Anon. Impr.

Rapide, Tunis. (Le

figuier, p. 96-100.) ------, 1934: Resistance to low winter temperatures of subtropical fruit plants. Amer.

Soc. Hort. Sci. Proc. 30: 349-354. Hogg, Robert, 1866: The fruit manual. 3rd ed. The Horticultural Press, London. Homerus, 1911: The Iliad of Homer. Translation by Arthur G. Lewis. The Baker

and Taylor Co., New York. Hone, William, 1832: The year book of daily recreation and information. Wm. Tegg

and Co., London. (Fico, p. 1086.) Hoppin, Charles A., 1926: The house in which George Washington was born.

Tylerl's Quart. Hist, and Gen. Mag. 8: 73-103. Horatius Flaccus (65-8 B.C.), 1902: Horace. Satires and epistles. English version

by Philip Francis. Unit Libr., London. Horn, C. L., 1931: Report of the horticulturist. Virgin Isl. Agr. Exp. Sta. Rpt. 1930:

7-10. Horton, J. R., 1917: Three-lined fig-tree borer. J our. Agr. Res. 11:371382. Howard, B. J., 1929: Fig testing. 11 p. U. S. Dept. Agr. Food, Drug, and Insect.

Admin.

-----, 1933: The influence of insects in the souring of figs. Jour. Econ. Ent. 2d: 917.

Howard, C. W., 1908: Report of the entomologist. Transvaal Dept. Agr. Ann. Rpt.

1908: 164-209. Howard, L. O., 1901: Smyrna fig culture in the United States. U. S. Dept. Agr.

Yearbook 1900: 79-106. Hunt, B. W., 1911: Fig breeding. Univ. of Georgia Bui. 11:146-148. 
------, 1914: The fig in Georgia. Ga. State Col. Agr. Bui. 2(12): 89-93.

Husain, M. A., and M. A. Khan, 1940: Bionomics and control of the fig-tree borer.

Indian J our. Agr. Sci. 10: 945-959. Hutson, J. C, 1937: Report on the work of the entomological division. Ceylon Dir.

Agr. Adm. Rpt. 1936: D22-28.

I bn-Al-Awam, 1864-1867: Le livre de Tagriculture. Par J . J. Clement-Mullet. 2

Vols. A. Franck, Paris. _ (Figuier, Vol. 1:277-281.) I hering, H. von, 1911: Os insectos nocivos da figueira e os meios de combatel-os.

Chacaras e Quintaes 3: 9-11. (See Exp. Sta. Rec. 26:147.) Iliinsky, A. M., 1916: Observations on the pests of Ficus carica in Kakhetia. Tiflis-

Erivan-Kars Bur. Control Pests of Agr. Bui. 2:1-19. (See Rev. Appl. Ent. 5:

303.) I rving, Washington, 1857-60: Life of George Washington. 5 Vols. G. P. Putnam

\& Co., New York. Isaakides, C. A., 1930: Hellenic republic: locust control. Internatl. Inst. Agr. Bui.

Plant Protect. 4:113-115.

Jack, R. W., 1923: Insect pests of fruits other than citrus. Rhodesia Dept. Agr. Bui.

450:1-40. (See Rev. Appl. Ent. 11: 238.) Jacobs, P. B., and H. P. Newton, 1938: Motor fuels from farm products. U. S.

Dept. Agr. Misc. Publ. 327:1-129. Jaffa, M. E., 1929: Food value of figs. Calif. Ann. Fig Inst. Proc. 13:42-47. J affa, M. E., and L. Anderson, 1901: Feeding of farm animals. Calif. Agr. Exp.

Sta. Bui. 132:1-54. Jamieson, G. S., 1943: Vegetable fats and oils. Reinhold Publ. Corp., New York. Jamieson, G. S., and R. S. McKinney, 1935: Caprified fig-seed oil. Oil and Soap

Ind. 12: 88. (See Chem. Abs. 29: 4196.) J efferson, Thomas, 1787: The writings of Thomas J efferson. The Thomas J efferson Mem. Assoc. 6:176, 177. (1903-1904.) J onson, Benjamin, 1609: The masque of queenes. N. Okes, London. J oslyn, M. A., and W. V. Cruess, 1929: Freezing storage of fruits and vegetables for 
retail distribution in paraffined paper containers. Fruit Prod. Jour. 8(7): 9-12;

(8) : 9-12. Joslyn, M. A., and G. L. Marsh, 1933: Changes occurring during freezing storage

and thawing of fruits and vegetables. Calif. Agr. Exp. Sta. Bui. 551:1-40. J uignet, Edmond, 1909: Culture du figuier a Argenteuil et dans le nord de la France.

Chez TAuteur, Argenteuil. Jukovsky, P. M., 1933: Zemledell 'cheskaia Turtsiia (Aziatskaia chastl'Anatoliia).

Moskva.

\section{Page 197}

The Fig

197

Bibliography

Kaloyereas, Socrates, 1930: The fig in Greece and elsewhere. Greek Agr. Society.

(In Greek.) Kearney, T. H., 1936: The choice of crops for saline land. U. S. Dept. Agr. Circ.

404: 1-24. Kieffer, D. L., 1928: So that peach and fig growers may know. Pacific Rural Press

115: 757.

------, 1929: The Peach and Fig dissatisfaction. Pacific Rural Press 117: 320.

------, 1936: Fig Institute entitled to praise. Pacific Rural Press 132: 722.

King, George, 1888: The species of Ficus of the Indo-Malayan and Chinese countries.

Royal Bot. Garden Calcutta Ann. Vol. 1, Part 2. King, H. H., 1911: Report of the entomological section. Gordon Mem. Col. Khartum,

Wellcome Res. Lab. Rpt. 4(B) : 95-150. Kojima, T., 1929: Immature stages of 
some J apanese Cerambycid beetles. Tokyo Imp.

Univ. Col. Agr. J our. 10:101-128. (See Rev. Appl. Ent. 17: 565.) Krauss, F. S., 1907: Das Geschlechtsleben in Glauben, Sitte und Brauch der Japaner.

Leipzig. Kuhrt, W. J., 1945: Bureau of Markets. California Dept. Agr. Bui. 34 (4) : 301-319.

Lagarde, Paul de, 1881: Ueber die semitischen Namen des Feigenbaums und der Feige. K. Gesell. der Wiss. zu Gottingen Nachr. 1881:368-396.

Laing, F., 1924: A new Psyllid injurious to fig trees. Bui. Ent. Res. 14:247.

Langworthy, C. F., 1913: Raisins, figs and other dried fruits and their use. U. S. Dept. Agr. Yearbook 1912: 505-522.

Lanham, W. B., et al, 1927: Spraying for the control of fig rust. Texas Agr. Exp. Sta. Circ. 47:1-8.

La Perouse, Jean, 1798: A voyage round the world. J. Johnson, London. (Translated from the French.)

La Quintinie, J ean de, 1692: Instructions pour les jardins fruitiers et potagers. Henri Desbordes, Amsterdam. Made English by J ohn Evelyn, 1693.

Laufer, Berthold, 1919: Sino-Iranica. In: Field Mus. Nat. Hist, Chicago, Anthrop. Ser. 15: 185-630.

LaWall, C. H., 1927: Four thousand years of pharmacy. J. B. Lippincott Co., Philadelphia.

Lawrence, D. H., 1939: Poems. Wm. Heinemann, London. (See Figs, Vol. 2:285.)

Lawrence, W. H., 1916: Practical fig culture in Arizona. Ariz. Agr. Exp. Sta. Bui. 77:1-43.

Lea, A. M., 1927: South Australian plant weevils. So. Austral. Dept. Agr. J our. 30: $582-598$.

Leclerc du Sablon, 1908: Observations sur les diverses formes du figuier. Rev. Gen. Bot. 20:129-150, 207-216.

Legare, J ohn D., 1831: Results of some experiments to ascertain the effect of oil in hastening the maturity of figs. So. Agriculturist 4: 532-536.

Leick, Erich, 1924: Die Kaprifikation und ihre Deutung im Wandel der Zeiten. 
Deut. Dendrol. Gesell. Mitt. 34:263-283.

Leite de Vasconcellos, J., 1925: A figa. Estudo de etnografia comparativa. Araujo e Sobrinho, Porto.

Lelong, B. M., 1892: Propagation, budding, grafting, and appliances. Calif. State Bd. Hort. Ann. Rpt. 1891: 145-180.

Leonard, M. D., 1925: Notes on the embargo of grapes from Almeria, Spain, on account of the Mediterranean fruit-fly. Jour. Econ. Ent. 18: 257-265.

Leonardi, Gustavo, 1920: Monografia delle cocciniglie Italiane. Ernesto della Torre, Portici.

Lichtenstein, J. L., et F. Picard, 1917: Etude morphologique et biologique du Sy-cosoter lavagnei, Hecabolide parasite de VHypoborus ficus. France et Belgique Biol. Bui. 51:440-474. (See Rev. Appl. Ent. 6:328.)

Lindley, George, 1831: A guide to the orchard and fruit garden. Longman, London.

Lindley, J ohn, 1841: Pomologia Britannica. 3 Vols. H. G. Bohn, London. (See Vol. 1:48.)

Linnaeus, C, 1737: Hortus Cliffortianus. Amstelaedami.

------, 1753: Species plantarum. L. Salvii, Holmiae.

Linsley, E. G., and A. E. Michelbacher, 1943: Insects affecting stored food products. Calif. Agr. Exp. Sta. Bui. 676:1-44.

Longo, Biagio, 1909: Osservazioni e ricerche sul F. carica. Ann. di Bot. [Torino] 7:234-256.

------, 1911: Sul Ficus carica. Ann. di Bot. 9:415-432.

\section{Page 198}

Gondit

198

The Fig

------, 1918: Primi risultati della seminagione del caprifico. R. Accad. Naz. dei 
Lincei,

Cl. di Sci. Fis., Mat. e Nat, Rend. 5 ser. 27(1) : 55-57. ------, 1924: Ulterior! risultati della seminagione del caprifico. R. Accad. Naz. dei

Lincei, Cl. di Sci. Fis., Mat. e Nat, Rend. 5 ser. 33(2) : 228-229. Loudon, J. C, 1854: Arboretum et fruticetum Britannicum. Longman, London. Loveman, Robert, 192- : Verses. Vail-Ballou Press, Binghamton, New York. Lupo, Vincenzo, 1943: II Mytilococcus ficifoliae e una forma estiva del M. conchi-

jormis. Portici R. Lab. di Ent. Agr. Bol. 5:196-205. Lutz, H. F., 1922:

Viticulture and brewing in the ancient Orient. Stechert, Leipzig.

M., 1871: Bourjassotte Grise fig. Florist and Pom., 3rd ser. 4: 31-32.

McBride, G. M., 1936: Chile: land and society. American Geogr. Soc, New York.

Mackaness, George, 1931: The life of Vice-Admiral William Bligh. Farrar and

Rinehart, New York. Mackie, D. B., 1934: Entomological service. Calif. Dept. Agr. Bui. 23:396-418.

------, 1935: Entomological service. Calif. Dept. Agr. Bui. 24:403-430.

Mackie, G. M., 1898: Bible manners and customs. Fleming H. Revell Co., New York. McKeown, K. C, 1942: Australian insects. Royal Zool. Soc. N. S. Wales, Sydney. McLester, James S., 1931: Nutrition and diet in health and disease. W. B. Saunders

Co., Philadelphia. MacPherson, David, 1805: Annals of commerce. Nichols and Son, London. Maffei, Luigi, 1925: Sul parassitismo di Phomopsis cinerescens sopri i rami del fico.

Riv. di Patol. Veg. 15: 37-47. Malenotti, E., 1928: Sulla sistematica dello Pseudococcus vitis ... Verona Accad.

Agr. Sci. Lett Atti 5: 51-62. (See Rev. Appl. Ent 17:150.) Martelli, G., 1925: Contro la Cocciniglia del fico. R. Osserv. di Fitopat. Puglie Cir.

2:1-6. (See Rev. Appl. Ent. 13: 266.) Maslin, E. W., 1890: Fig culture and seedling Smyrna figs. California State Bd.

Hort. Rpt. 1889: 401-405. Mason, S. C, 1911: Drought resistance of the olive in the southwestern States. U. S.

Dept. Agr. Bur. PI. Ind. Bui. 192: 9-44. Massalongo, Caro, 1888: 
Contribuzione alia teratologia vegetale. Nuovo Giorn. Bot.

Ital. 20:261-293. Massee, George, 1900: A fig disease. Gard. Chron. 28: 5. July 7.

------, 1911: Diseases of cultivated plants and trees. The Macmillan Co., New IYork.

Massey, W. F., 1893: The propagation, planting, and culture of fruit trees. N. C.

Agr. Exp. Sta. Bui. 92: 5-63.

------, 1894: Raising figs from seed. Amer. Agric. 53: 69.

-----, 1903: The fig. N. C. Agr. Exp. Sta. Bui. 184:123-125.

Matthew, Alexander, 1925: Candying of fresh figs. Fruit Prod. J our. 5(2) : 1618;

(3): 18-20; (4) : 18-20. Matz, Julius, 1917: A Rhizoctonia of the fig. Phytopathology 7:110-118.

-----, 1918: Some diseases of the fig. Fla. Agr. Exp. Sta. Bui. 149:3-10.

Mauri, N., 1939a: Les caprifiguiers utilises en Kabylie pour la caprification. Algerie

Serv. Arbor. Bui. 6: 3-39;

------, 19396: Les figuiers cultives en Kabylie. Algerie Serv. Arbor. Bui. 5: 3-66.

------, 1942: Les figuiers cultives en Algerie. Algerie Serv. Arbor. Bui. 93:1-56;

Bui. 93, bis: 1-103, 98 figs. 1944. Mazieres, E. de, 1920: Le figuier, Tabricotier, le prunier, et I'industrie des fruits

seches. J.-B. Bailliere et Fils, Paris. Meissner, Bruno, 1920-1925: Babylonia and Assyria. C. Winter, Heidelberg. Melo Leote, F. C, 1900: Arboricultura algarvia. (Cited by Bobone.) Menendez, Pedro, 1579: A la Audiencia de Santo Domingo, San Agustin, 2 Abril de

1579. Translation by J eannette T. Connor, in Colonial Records of Spanish

Florida 2: 227. MEREZHKOVSKn, D. S., 1931: The romance of Leonardo da Vinci. Random House, 
New York. Mildbraed, J., und M. Burret, 1911: Die Afrikanischen Arten der Gattung Ficus.

Bot. Jahrb. 46:163-269. Miller, C. D., et ah, 1936: Some fruits of Hawaii: their composition, nutritive value,

and use. Hawaii Agr. Exp. Sta. Bui. 77:1-133. Miller, Philip, 1768: The gardeners dictionary. London, pr. for the author. Mingioli, E., 1904: L I'industria dei fichi secchi. Soc. degli Agr. Ital. Bol. Ser. 2,

9:624-632, 6S6-663. Miranda, Victor, 1915: Arboles frutales. Libr. de Francisco Puig, Barcelona.

(Higuera, p. 126-137.)

\section{Page 199}

The Fig

199

Bibliography

Mirbel, C. F., 1813: Nouvelle classification des fruits. Paris Soc. Philomatique Bui.

3:313-319. M 'Mahon, Bernard, 1857: The American gardenenl's calendar. Ed. 11. J. B. Lippin-

cott and Co., Philadelphia. Mohamed, M. S., and E. M. Mrak, 1942: Relation of variety and stage of development to composition of figs. Food Research 7: 495-502. Monastero, S., 1930: II Ficus carica infestato dal Cossus cossus. Palermo 1st. Zool.

Bui. 2:41-44. (See Rev. Appl. Ent. 19:228.) Moore, Thomas, 1872: Negro Largo fig. Florist and Pom. 3rd ser. 5: 145. Moorhead, E. S., 1921: The birth of a new fig industry. Assoc. Grower 2(12) : 8-9.

Dec.

------, 1924: The canning of figs. Canning Age 5(2) : 105. Feb.

Moquin-Tandon, A., 1841: Elements de teratologic vegetale. P. J . Loss, Paris. Morgan, Agnes F., 1932: The unusual nutritive value of figs. Pacific Rural Press 
123:6.

------, 1941: A nutritive index of fruits. Fruit Prod. Jour. 21: 75-77.

Morgan, A. F., G. D. Hatfield, and M. A. Tanner, 1926: A comparison of the effects

of supplementary feeding of fruits and milk on the growth of children. Amer.

J our. Dis. of Children 32: 839-849. Morgan, A. F., Anna Field, and P. F. Nichols, 1932: Recent studies of the vitamin

A and C content of dried apricots and figs. Fruit Prod. Jour. 11: 304. Morgan, A. F., et al.f 1935: The vitamin content of figs. J our. Nutr. 9:383-394. Morris, H. M., 1920: The Hypopus of Carpoglyphus anonymus. Ann. Trop. Med ', and

Parasitol. Liverpool 13:339-342. (See Rev. Appl. Ent. 8:222.) Moulton, D., 1930: A new genus and species of Thysanoptera from Chile. Chile

Hist Nat Rev. 34:272-275. Mrak, E. M., 1941: Retention of vitamins by dried fruits and vegetables. Fruit Prod.

J our. 21:13-15. Mrak, E. M., et al., 1942: Yeasts occurring in souring figs. J our. Bact. 44: 441-450. Mrak, E. M., and J. D. Long, 1941: Methods and equipment for the sun-drying of

fruits. Calif. Agr. Exp. Sta. Circ. 350:1-69. Muller, Wilhelm, 1925: Examination and judging of coffee substitute made from

figs. (Transl. title.) Mitt. Lebensm. Hyg. 16:1-5. (See Chem. Abs. 19:1917.) Munro, H. K., and F. A. Fouche, 1936: A list of the scale insects and mealy bugs and

their host plants in South Africa. Union So. Africa Dept. Agr. and For. Bui.

158: 3-104. Murakami, S., 1936: Observations on Chrysomelidae. Nojikairyoshiryo, Tokyo

(106) :46-54. (See Rev. Appl. Ent 24:694.) Muschler, Reno, 1912: Manual flora of Egypt. R. Friedlaender, Berlin.

Nadir, A., and M. Halit, 1929: The fig industry of Smyrna. Calif. Ann. Fig Inst.

Proc. 13:33-36. Nelson, E. K., 1928: The acids of figs. Amer. Chem. Soc. J our. 50:2012. Newell, W., and T. C. Barber, 1913: The Argentine ant. U. S. Dept. Agr. Bur. Ent. 
Bui. 122:5-98. Nichol, A. A., 1935: A study of the fig beetle, Cotinis texana. Ariz. Agr. Exp. Sta.

Tech. Bui. 55:157-198. Nichols, P. F., and H. M. Reed, 1932: Experiments in harvesting and drying figs.

Fruit Prod. J our. 11:237-240. Nisikado, Y., et al., 1941: On a Phytophthora rot of fig. Ohara Inst. f. Landw.

Forsch. Ber. 8: 427-442. (See Hort Abs. 11: 292.) Niswander, J. F., 1920: Peach Growers and Fig Growers unite. Assoc. Grower

1(3) : 1. May. Noble, E. G., 1922: The work of the Yuma Reclamation Project Experiment Farm in

1919 and 1920. U. S. Dept. Agr. Dept. Circ. 221: 3-37. Noisette, Louis, 1829: Manuel complet du jardinier. A. Wahlen et H. Tarlier, Brux-

elles.

Ojima, G., 1919: Fig-boring insect. Byochugai Zasshi (J our. PI. Protection) Tokyo

6:427-430. (See Rev. Appl. Ent. 7: 369.) Okahara, Kunio, 1936: Ueber die in den Blattern von Ficus carica enthaltenen

Bestandteile. Japan. Chem. Soc. Bui. 11:389-394. Oliver, G. W., 1903: The propagation of tropical fruit trees and other plants. U. S.

Dept. Agr. Bur. PI. Ind. Bui. 46: 5-26. Olivier, G. A., 1801: Travels in the Ottoman Empire, Egypt, and Persia. 2 Vols.

Longman, London.

\section{Page 200}

Condit

200

The Fig

[Orr, Mrs. Lucinda], 1871: J ournal of a young lady of Virginia, 1782. J ohn Murphy 
and Co., Baltimore. Osborn, H. T., 1938: Introduction into the Hawaiian Islands of Mexican enemies of

the avocado mealybug. Hawaii. Planters Rec. 42: 153-158. Overholser, E. L., 1922: Keeping the fig in fresh condition by low temperatures.

Assoc. Grower 3(6) : 9, 33. June. Ovtedo y Valdes, Gonzales, 1526: Historia general y natural de las Indias. Toledo.

Pais, Ettore, 1906: Ancient legends of Roman history. Transl. by Mario E.

Cosenza. Sonnenschein, Swan, and Co., London. (Fig, p. 47-59.) Paladino, R., 1910: Ueber die chemische Zusammensetzung der Feige. Biochem.

Ztschr. 24: 263-265. (Abs. in: Chem. Abs. 4: 1635.) Parker, W. B., 1915: Control of dried-fruit insects in California. U. S. Dept. Agr.

Bui. 235: 1-15. Parkinson, J ohn, 1640: Theatrum botanicum. Tho. Cotes, London. Partridge, Sarah W., 1920: Florida fig products. Florida Grower 22 (7) : 7. Aug.

14. Paton, W. R., 1907: Pharmakoi. Revue Archeologique ser. 4, vol. 9:51-57. Pellicano, A., 1907: II fico nel circondario di Gerace. Bol. Arbor. Ital. Anno 3: $122-$

150. Pentzer, W. T., and C. E. Asbury, 1931: Observations on the freezing storage of

figs. Fruit Prod. J our. 10(7) :218. ------, ------, 1932: Progress report on figs and grapes. Western Canner and Packer

24(3): 24. July. Penzig, O., 1921-22: Pflanzen-teratologie. 3 Vols.

Borntraeger, Berlin. Pereira Coutinho, A., 1913: A flora de Portugal. Aillaud et Cie, Paris. (Cited

by Bobone.) Peterson, W. A., 1913: Figs. U. S. Dept. Agr. Bur. PI. Ind. Circ. 126:22-23. Petri, L., 1906: Ricerche sopra la batteriosi del fico. R. Accad. Naz. dei Lincei, Atti

Cl. di Sci. Fis., Mat. e Nat. Rend. 15: 644-651. (See Exp. Sta. Rec. 18:649.) Phillips, Edith, et al, 1925: Fig smut. Calif. Agr. Exp. Sta. Bui. 387:3-38.

Phillips, Henry, 1831: The companion for the orchard. Henry Colburn and R.

Bentley, London. Picard, F., 1914: Les insectes du figuier. Prog. Agr. et Vit. 62:279-286. (See Rev.

Appl. Ent. 3:10.) ------, 1919: La faune entomologique du figuier. Ann. des 
Epiphyt. [Paris] 6: 34-174.

(See Rev. Appl. Ent. 9: 23.) ------, 1919: Sur un Ichneumonide parasite de YHesperophanes griseus dans les branches

du figuier. Soc. Ent. de France Bui. 1919: 77-80. (See Rev. Appl. Ent 7: 268.) Piper, S. E., 1944: Field activities. Calif. Dept. Agr. Bui. 33:288-290. Potman, H. A., 1935: Fig leaf mottle. West Austral. Dept. Agr. J our. 2nd ser.,

12:196. Planchon, Gustave, 1864: Etude des tufs de Montpellier. F. Savy, Paris. Plinius Secundus, Gaius (23-79 A. D.), 1855-1890: The natural history of Pliny.

6 Vols. English translation by J ohn Bostock and H. T. Riley. H. G. Bohn, London. Plutarch (46-120 A. D.), 1905: Plutarchl's lives. 5 Vols. Translation by $A$. M.

Clough. A. L. Burt, New York. (Solon, p. 154-185.) -----, 1914: Solon. In: Plutarchl's lives. Wm. Heinemann, London. (See Vol. 1:

XXIV, 471.) ------, 1896: De Curiositate. Translation by Queen Elizabeth. In: Early English

Text Soc. 113:121-141. Pontedera, Giulio, 1720: Anthologia, sive de floris natura. Typ. Seminarii, Patavii. Popov, M. G., 1929: Wild fruit trees and shrubs of Asia Media. Bui. Appl. Bot,

Genet., and Plant Breeding 22(3) : 241-483. Porta, Giovanni B., 1583: Suae villae pomarium. Neapoli. Portale, F., 1910: La coltivazione del fico nel circondario di Mistretta. Bol. Arbor.

Ital. Anno 6:49-101. Post, G. E., 1902: Figs. In Vol. 2: A dictionary of the Bible, edited ' ' by J ames Hastings. Scribnerl's Sons, New York. ------, 19321933: Flora of Syria, Palestine and Sinai. 2nd ed. by J. E. Dinsmore.

2 Vols. American Press, Beirut. Potts, A. T., 1917: The fig in Texas. Texas Agr. Exp. Sta. Bui. 208: 5-41. Poutiers, R., 1921: Lonchaea aristella, nuisible au figuier, nouvelle pour la France.

Prog. Agr. et Vitic. Montpellier 76:285-286. (See Rev. Appl. Ent. 9:545.)

\section{Page 201}

The Fig 201 Bibliography

Powell, Alexander, 1926: In Barbary. Century Co., New York. 
Price, R. H., and E. A. White, 1902: The fig. Texas Agr. Exp. Sta. Bui. 62:1729.

Priego J aramillo, J. M., y Santiago Sanchez, 1922: La higuera: su cultivo en

Espafia. Calpe, Madrid. Prunet, A., et B. Aggery, 1918: Les maladies du figuier. (France) Min. de II'Agr.

Ann. du Serv. Epiph. 6: 175-186. \{See Exp. Sta. Rec 46: 48.) Puente y Olea, Manuel de la, 1900: Los trabajos geograficos de la Casa de Con-

tratacion. Escuela Tipografica, Sevilla. Pyenson, Louis, 1938: The problems of applied entomology in Pernambuco, Brazil.

Part 2. Rev. de Ent. 9:16-31.

Quayle, H. J., 1914: Citrus fruit insects in Mediterranean countries. U. S. Dept. Agr. Bui. 134: 1-35. ------, 1938: Insects of citrus and other subtropical fruits. Comstock Publ. Co., Ithaca.

Ramachandra Rao, Y., 1922: Notes on the life-histories of two Mesopotamian moths.

Bui. Ent. Res. 12:477-479. Ravasini, Ruggero, 1911: Die Feigenbaume Italiens und ihre Beziehungen zu Ein-

ander. 174 p. Bern. Read, F. W., 1929: Review of fresh fig shipments for 1929. Calif. Ann. Fig Inst. Proc.

13:16-18. Reed, H. M., 1932-1940: Fig-products investigations. Texas Agr. Exp. Sta. Rpt.

45:135; 46:148; 47:159; 48:165; 49:194-196; 51:143; 52:161; 53:156. ------, 1933: I mproved methods of utilizing the Magnolia fig. Texas Agr. Exp. Sta.

Bui. 483:5-20.

------, 1934: Drying Magnolia figs in Texas. Fruit Prod. Jour. 13: 370.

------, 1939: The freezing storage of figs. Ice and Refrig. 96:425.

Reed, H. M., and S. H. Yarnell, 1939: Fig breeding work. Texas Agr. Exp. Sta. 
Ann. Rpt. 52:161.

-----,-----, 1940: Fig breeding. Texas Agr. Exp. Sta. Ann. Rpt. 53:156.

Reimer, F. C, 1910: Fig culture in North Carolina. N. C. Agr. Exp. Sta. Bui. 208:

187-206. Reinach, Salomon, 1908: Cultes, mythes, et religions. Vol. 3. E. Leroux, Paris. Reinach, Theodore, 1890: Mithridates Eupator, Roi de Pont. Firmin-Didot, Paris. Reinhardt, Ludwig, 1910: Die Kulturgeschichte der Nutzpflanzen. Ernst Reinhardt,

Miinchen. Renner, Otto, 1906: Beitrage zur Anatomie und Systematikinsbesondere der Gat-

tung Ficus. Bot. Jahrb. 39: 319-448. Ritter, Carl, 1866: The comparative geography of Palestine and the Sinaitic peninsula. D. Appleton and Co., New York. Translated by W. L. Gage. Riviere, Augusts, et Gustave Riviere, 1928: Traite $d$ 'arboriculture fruitiere. I mprim.

du Reveil du Beaujolais, Villefrancfye. (Figuier, p. 532-541.) Riviere, Gustave, et G. Pichard, 1926: De la composition chimique des meilleures

varietes de figues hatives recoltees sous le climat de Paris. Soc. Natl. $d l$ 'Hort. de

France J our. ser. 4, 27: 475-477. Rixford, G. P., 1915: Split figs and irregular water. Pacific Rural Press 89:684.

------, 1918: Smyrna fig culture. United States Dept. Agr. Bui. 732:1-43.

------, 1919: The Maslin seedling fig orchard. Calif. Cult. 53(7) : 169, 177.

------, 1920: A non-splitting Smyrna fig and its history. Fig and Olive J our. 4 (8) : 9 .

Jan.

------, 1926: Work with seedling figs. Calif. Ann. Fig Inst. Proc. 10:6-9. (Mimeo.)

Rixford, G. P., and F. Heiny, 1911: Interesting event in fig growing. Calif. Cult. 36:390. Rjabov, I. N., 1939: Results of 125 years।' work on fruit production at Molotov's

Nikita Botanical Garden. Lenin Acad. Agr. Sci. Moscow 1939: 79-135. (Abs. in: 
PI. Br. Abs. 10, No. 988.) Roeding, G. C, 1903: The Smyrna fig at home and abroad. The author, Fresno, Calif.

------, 1910: The plain facts of fig wasp history. Calif. Cult. 35:659.

------, 1917: Graftingdo it now. Calif. Cult. 48:219.

Rolet, Antonin, 1916: Le figuier en Provence. La Vie Agr. et Rurale 6:170172. Rosa, Francesco de, 1911: Di alcuni fichi Salentini. R. 1st. dl 'Incoragg. di Napoli

Atti, Ser. 6, 9: 375-412. Rose, Dean H., et aL, 1933: The commercial storage of fruits, vegetables and florists।'

stocks. U. S. Dept. Agr. Circ. 278:1-39. Rev. ed. 1938. Rosewell, O. W., 1920: Anasa tristis feeding on leaves and fruit of the fig tree. J our.

Econ. Ent. 13:148.

\section{Page 202}

Condit

202

The Fig

Rothers, B. V., 1928: Fig leaf disease. La Defense des Plantes, Leningrad 4:962.

\{See Rev. Appl. Mycol. 7: 427.) Roullard, F. P., 1923: Diseases on fig roots. Fresno Bee, Jan. 20. Rusby, Henry H., 1923: Ficus. In: A reference handbook of the medical sciences,

Vol. 4: 401. Wm. Wood and Company, New York. Rust, E. W., 1918:

Anastrepha fraterculus, a severe menace to the southern United

States. Jour. Econ. Ent. 11:457-467.

Saccardo, P. A., 1886: Sylloge fungorum. Vol. 4. Typis Seminarii, Patavii. \{See

p. 475.) Sale, Edith T., 1830: Historic gardens of Virginia. Richmond. Salmon,

E. S., and H. Wormald, 1916: The fig canker, caused by Phoma cinerescens. 
Ann. Appl. Biol. 3:1-12. Sanford, S. N. F., 1933: Ficus carica in Massachusetts. Rhodora 35: 40. Saporta, Gaston, 1873: Sur Texistence du figuier dans environs de Paris a I 'epoque

quaternaire. Soc. Geol. France Bui. 2:442. Sapozhnikova, E. V., 1940: The chemical composition of fruits and latex of Ficus

carica. Biokhim. Kultur Rastenii 7: 485-488; 488-491. \{See Chem. Abs. 35:

3287.) Savage, C. G., 1925: Smyrna fig culture. So. Austral. Dept. Agr. Bui. 186:3-20. Savastano, L., 1915: La mosca nera dei fichi. Acireale R. Staz. Sper. di Agrumic.

e Fruttic. Bol. 17:1-4. \{See Rev. Appl. Ent. 3: 745.) ------, 1917: Contribute alio studio sui rapporti biopatologici della mosca nera del fico

ed il suo ospitante nella Penisola Sorrentina. Acireale R. Staz. Sper. di Agrumic.

e Fruttic. Ann. 4:113-146. \{See Rev. Appl. Ent. 6:75.) ------, 1923: Delle epidemie italiene del mal secco negli agrumeti, albicoccheti, ficheti,

noceti, e gelseti. Studio di clinica arborea. Acireale R. Staz. Sper. di Agrumic.

e Fruttic. Ann. 7:89-170. Sayre, L. E., 1906: A manual of organic materia medica and pharmacognosy. P.

Blakistonl 's Son and Co., Philadelphia. Saywell, L. G., 1932: The effect of figs and small amounts of raisins on urinary

acidity. J our. Nutr. 5: 519-525. Schreiber, W. R., 1945a: Survey of the world fig situation. Foreign Fig Report No.

60. Federal-State Market News Service, Sacramento. 1945\&: Turkish fig crop larger than last year. Foreign Fig Report No. 61.

Federal-State Market News Service, Sacramento. Schwarz, O., and A. Vasfi, 1933: Beitrage zur Pathologie der Feige, Ficus carica.

I. Das Fruchtfauleproblem in Kleinasien. Phytopath. Ztschr. 6: 589-618. Scott, Hugh, 1929: Note on the life-history of the fig-tree moth. Bui. Ent. Res. 20:

39-40. Sevket, N., 1934: Die Feigeninsekten und die wesentlichsten Ursachen der Feigen-

fruchtfaule. Anz. f. Schadlmgsk. 10: 118-119. \{See Rev. Appl. Ent. 22: 723.) Shear, S. W., 1929: Some aspects of the economic status of the fig industry. 
Calif.

Fig Gr. Ann. Inst. Proc. 13:36-39. Shinn, J. C, 1892: The fig in California. Calif. Agr. Exp. Sta. Bui. 96: 3-6. Shiraiwa, H., 1935: Studies on mealy bugs infesting pear in Japan. Kontyu 9:63-75.

\{See Rev. Appl. Ent. 23: 611. ) Silvestri, F., 1917: Descrizione di una specie di Oscinosoma osservato in fruttescenze

di caprifico. Portici R. Scuola Super, di Agr. Lab. Zool. Gen. e Agr. Bol. 12:

147-154. \{See Rev. Appl. Ent. 6:77.) ------, 1917: Sulla Lonchaea aristella, dannosa alle inflorescenze e fruttescenze del

caprifico e del fico. Portici R. Scuola Super, di Agr. Lab. Zool. Gen. e Agr. Bol.

12:123-146. \{See Rev. Appl. Ent. 6: 75-77.) ------, 1927: II Ceroplaste del fico. Portici R. Lab. di Ent. Agr. Circ. 4: 1-11. \{See

Rev. Appl. Ent. 17:633.) Simmons, Chas., 1924: Smyrna fig culture in Western Australia. West. Austral.

Dept. Agr. J our. ser. 2, 1:468-471. Simmons, Perez, et al., 1931: Fig insects in California. U. S. Dept. Agr. Circ. 157:

1-71. ------, 1933: Results of 1932-crop experiments in insect control. Calif. Dried Fruit

Assoc. Bui. 1480:1-3. Siniscalchi, A., 1911: La coltivazione del fico nel Cilento. 22 p. O. delle Ferrovie,

Acireale. Smart, Helen F., 1934: Microorganisms surviving the storage period of frozen-pack

fruits and vegetables. Phytopathology 24:1319-1331.

\section{Page 203}

The Fig

203

Bibliography

Smith, C. O., 1913: Some successful inoculations with the peach crown gall 
organism.

Phytopathology 3: 59-60. Smith, Elizabeth H., and Edith Phillips, 1922:

Studies of the so-called "smut" of

white fig varieties. Calif. Dept. Agr. Mo. Bui. 11: 755-758. Smith, G. M., et ah, 1928: A textbook of general botany. The Macmillan Co., New

York. Smith, J ohn, 1910: Travels and works of Captain J ohn Smith (15801631). John

Grant, Edinburgh. Edited by Edward Arber. New ed. by A. G. Bradley. Smith, J ohn, 1877: Bible plants. Hardwick and Bogue, London. Smith, R. E., 1941: Diseases of fruits and nuts. Calif. Agr. Ext. Serv. Circ. 120:1-

168. Smith, R. E., and H. N. Hansen, 1927: The improvement of quality in figs. Calif.

Agr. Exp. Sta. Circ. 311:1-23.

-----, 1931: Fruit spoilage diseases of figs. Calif. Agr. Exp. Sta. Bui. 506: 1-84.

Smyth, E. G., 1911: Report on the fig moth in Smyrna. U. S. Dept. Agr. Bur. Ent.

Bui. 104:41-65. Solms-Laubach, H. G., 1882: Die Herkunft, Domestication und Verbreitung des

gewohnliches Feigenbaums. Abhandl. K. Ges. Wiss. Gottingen 28:1-106. -----, 1885: Die Geschlechterdifferenzierung bei den Feigenbaumen. Bot. Zeitung 43:

514-522, 530-539, 546-551, 562-571. Sorber, D. G., 1935: A new by-product from cull and surplus fresh fruit. Blue Anchor

12(1): 4, 18. Spangler, R. L., 1930: Market demand for canned figs. U. S. Dept. Agr. Bur. Agr.

Econ. 14 p. (Mimeo.) Stahl, A. L., 1935: The composition of numerous tropical and subtropical fruits. Fla.

State Hort. Soc. Proc. 48:159-166. Standley, P. C, 1920-1926: Trees and shrubs of Mexico. U. S. Nat. Herb. Contrib.

23:1-1721. (Fig, p. 206.) Stansel,. R. H., 1931: Figs. Texas Agr. Exp. Sta. Ann. Rpt. 44:121-122. 
,----- 1933: Figs. Texas Agr. Exp. Sta. Ann. Rpt. 46:148.

Stansel, R. H., and R. H. Wyche, 1932: Fig culture in the Gulf Coast region of Texas. Texas Agr. Exp. Sta. Bui. 466:1-28. Stansel, R. H., and S. H. Yarnell, 1936: Fig investigations. Texas Agr. Exp. Sta.

Ann. Rpt. 49:32. Starnes, H. N., 1903: The fig in Georgia. Ga. Agr. Exp. Sta. Bui. 61:49-74.

-----, 1907: Fig culture. Amer. Fruit and Nut J our. 4:11-13. Jan.

Starnes, H. N., and J. F. Monroe, 1907: The fig in Georgia. Ga. Agr. Exp. Sta.

Bui. 77:41-101. Stevens, F. L., und J. G. Hall, 1909: Eine neue FeigenAnthraknose. Ztschr. f.

Pflanzenkrank. 19:65-68.

.-----,----, 1910: Diseases of economic plants. The Macmillan Co., New York.

Steiner, G., 1940: On the occurrence of the banana nematode in the United States.

PL Dis. Rep. Suppl. 124:146. -----, 1942: Crotalaria spectabilis immune to root-knot nematode. In: U. S. Dept.

Agr. Bur. PL Ind. Rpt. 1942:18-19. Stiner, Harry, 1932: Baby fumigators enable Turks to get rid of insects. Food Ind.

4:240-242. Streets, R. B., 1937: Phymatotrichum (cotton or Texas) root rot in Arizona. Arizona Agr. Exp. Sta. Tech. Bui. 71:299-410. Strong, L. A., 1935: Dried-fruit insects. U. S. Dept. Agr. Bur. Ent. PL Quar. Rpt

1935:4. Subba Rao, C. K., 1908: Notes on fig cultivation in southern India. Madras Dept

Agr. Bui. Vol. 3(57) : 135-143. Swingle, W. T., 1899: The dioecism of the fig in its bearing upon caprification. Science, n.S., 10:570-574. -----, 1908: Some points in the history of caprification and in the life history of the

fig. Calif. Fruit Growers Conv. Proc. 34:178-187. -----, 1909a: The Maslin seedling fig orchard and its bearing on the Smyrna fig industry of this country. Calif. Fruit Growers Conv. Proc. 35: 92-99. -----, 1909\&: Cooperative distribution of new varieties of Smyrna figs and caprifigs.

U. S. Dept. Agr. Bur. PL Ind. No. 438. 6 p. Second rev. B.P.I. No. 537. Jan. 
1912. -----, 1909c: The Rixford: a new type of Smyrna fig. Pacific Rural Press 77:161,

170.

\section{Page 204}

Condit

204

The Fig

Swingle, W. T., and G. P. Rixford, 1911: The first establishment of Blastophaga in

California. Calif. Fruit Growers Conv. Proc. 38: 174-179. Symeonides, P. M., 1930: The production of figs in Cyprus. Cyprus Agr. J our. 24(3) :

106-109.

Taubenhaus, J. J., 1936: A fig decay. Texas Agr. Exp. Sta. Ann. Rpt. 49: 113. Taubenhaus, J. J., and W. N. Ezekiel, 1931: A Sclerotinia limb blight of figs.

Phytopathology 21:1195-1197. ------,------, 1936: A rating of plants with reference to their relative resistance or susceptibility to root rot. Texas Agr. Exp. Sta. Bui. 527:5-52. Taubenhaus, J. J., and J. N. Roney, 1935: Stem blight of fig. Texas Agr. Exp.

Sta. Ann. Rpt. 48:101. Taylor, A. L., 1943: The effect of root-knot on fig seedlings. PI. Dis. Rep. 27:224. Taylor, W. A., 1898: The fruit industry. U. S. Dept. Agr. Yearbook 1897:305-344. Tessier, P., 1937: Une maladie du figuier en Kabylie. Rev. de Bot. Appl. et dl'Agr.

Trop. 17:371-372. Theocritus (3rd Cent. B. C), 1880: Theocritus. Translation by A. Lang. Mac-

millan \& Co., London. ------, 1924: Idylls of Theocritus. Translation by J. H. Hallard. Geo. Routledge.

London. Theophrastus, Eresios (372-287 B.C.), 1916: Enquiry into plants. Translated by

Sir Arthur Hort. G. Putnaml 's Sons, New York. Thiselton-Dyer, Thomas, 1876: 
British popular customs present and past. George

Bell and Sons, London. Thomas, Owen, 1904: In: The fruit garden, by George Bunyard and Owen Thomas.

Offices of Country Life, London. (The fig, p. 51-58.) Thompson, Alice R., 1915: The composition of Hawaiian fruits and nuts. Hawaii

Agr. Exp. Sta. Rpt. 1914:62-73. Thomson, David, 1881: Handybook of fruit culture under glass. W. Blackwood and

Sons, Edinburgh. Thorne, Gerald, 1934: Some plant-parasitic nemas, with descriptions of three new

species. J our. Agr. Res. 49: 755-763. Thurber, E. R., 1919: Resistance of figs to oak fungus. Pacific Rural Press 97:354. Thursby, I sabelle S., 1932: The fig, a prize package of food and medicine. Fla.

Coop. Ext. Work in Agr. and Home Econ. Circ. 24: 1-4. ------, 1943: Can surplus fruits and vegetables. Fla. Coop. Ext. Work in Agr. and

Home Econ. Bui. 121: 3-55. (Figs, p. 26-27.) Tims, E. C, 1933: Stilbum cinnabarinum, the cause of a new fig disease in Louisiana.

Phytopathology 23: 35.

------, 1934: Thread blight of fig in Louisiana. Plant Dis. Rep. 18: 98.

------, 1935: A Stilbum disease of fig in Louisiana. Phytopathology 25:208-222.

------, 1941: A new leaf spot of fig. (Abstract.) Phytopathology 31: 771.

Tims, E. C, and Frances Bonner, 1942: Studies of fig leaf blights. La. Acad. Sci.

Proc. 6:13-34. Toomey, W. F., 1917: The fig industry from the standpoint of a packer. Calif. Fig

Inst. Proc. 1: 90-94. Tournefort, J oseph P., 1718: Relation dl 'un voyage du Levant. 2 Vols. Imprim.

Royale, Paris. Towneley, Sir J ohn, 1420: The Towneley mysteries. Publ. of the Surtees Society,

1834. J. B. Nichols and Son, London. Trabut, L., 1901: La caprification en Algerie. Algerie Gouvt. Gen. Dir. de II'Agr., 
Serv. Bot. Bui. 32:115-138. ------, 1901: Le Ceroplaste ou cochenille du figuier et ses ennemis. Algerie Gouvt.

Gen. Dir. de II'Agr., Serv. Bot. Bui. 34:13-19. ------, 1904: Le figuier en Algerie. Algerie Gouvt. Gen. Dir. de PAgr. Serv. Bot. Bui.

28:1-37.

------, 1922: Sur les origines du figuier. Rev. Bot. Appl. Agr. Colon. 2:393-396.

-----, 1923-24: Le figuier. Algerie-Tunisie-Maroc Bui. Agr. 2nd ser. 29(Nos. 212) ;

30 (No. 2). Traub, H. P., and G. S. Fraps, 1928: Ripening and composition of the Texas Magnolia fig. Amer. Soc. Hort. Sci. Proc. 25: 306-310. Traub, H. P., and T. R. Robinson, 1937: Fig improvement. U. S. Dept. Agr. Yearbook Sep. No. 1589:1-10. Traub, H. P., and R. H. Stansel, 1930: The lateral root spread of the fig tree. Amer.

Soc. Hort. Sci. Proc. 27:109-113.

\section{Page 205}

The Fig

205

Bibliography

Tressler, D. K., 1942: Nutritive value of dried and dehydrated fruits and vegetables.

N. Y. State Agr. Exp. Sta. Tech. Bui. 262: 1-44. Tschirch, A., 1911: Die Feigenbaume Italiens und ihre Beziehungen zueinander.

Deut. Bot. Gesell. Ber. 29:83-96. Turner, William, 1568: The first and second partes of the herbal of William Turner.

A. Birckmann, Cologne. (Virtues of the figge tree, Part 2, p. 2.) Tyler, J ocelyn, 1933: The root-knot nematode. Calif. Agr. Exp. Sta. Circ. 330:1-33.

Rev. ed. 1944.

Umnov, M. P., 1940: The pests of the fig in the Crimea. Soviet Subtropics No. 3 (67) : 41-45. (See Hort. Abs. 10:137.) 
Vallese, F., 1904: La caprificazione in Terra dl'Otranto. Soc. Coop., Lecce.

-----, 1909: II fico. F. Battiato, Catania.

Vancouver, George, 1798: A voyage of discovery to the North Pacific Ocean. C. G. and J. Robinson, London.

Van Lennep, H. J ., 1875: Bible lands, their modern customs and manners. Harper and Bros., New York.

Van Velzer, A. C, 1909: Fig culture. 218 p. J. V. Dealy Co., Houston.

Varro, Marcus T., (116-27 B.C.), 1912: Varro on farming. Translation by Lloyd Storrs-Best. G. Bell and Sons, London.

Vasseux, A., 1920: Alcohol from sugars and from figs. (Transl. title.) Assoc, des Chim. de Sucr. et Distill. Bui. 37: 451. (See Chem. Abs. 14: 3292.)

Vavilov, N. I., 1931: Role of Central Asia in origin of cultivated plants. Bui. Appl. Bot, Genet., and Plant Breeding 26: 31-44. II

Venegas, Miguel, 1759: A natural and civil history of California. J. Rivington, London.

Venkata Rao, M. K., 1916: Some diseases of trees in Mysore. Bombay Nat. Hist. Soc. J our. 24:615.

Viatkin, V., 1936: Reactions of the fig tree to low temperatures. Soviet Subtrop. 1936:43-49.

Vjnogradov-Nititin, P., 1929: Fruit and nourishing trees in the forests of Transcaucasia. Bui. Appl. Bot., Genet., and Plant Breeding 22:3-211.

Viviand-Morel, V., 1890: Figue prolifere. Lyon Soc. Bot. Bui. 8:13.

Wallace, H. C, 1922: Rules and regulations for the enforcement of the Federal Food

and Drugs Act. U. S. Dept. Agr. Office Seer. Circ. 21: 1-27. Walti, A., 1938: Crystalline ficin. Amer. Chem. Soc. J our. 60: 493. Warburg, Otto, 1904: Die Gattung Ficus im nichttropischen Vorderasien. In: Festschrift zur Feier des siebzigsten Geburtstages des Herrn Prof. Ascherson, p. 364-

370. Leipzig, Borntraeger. Watson, J. R., 1940: Spraying fruits. Fla. Grower 48 (12) : 14. Dec. Watson, J. R., and C C. Goff, 1937: Control of root-knot in Florida. Fla. Agr. Exp. 
Sta. Bui. 311:3-22. Watson, J. R., and H. E. Bratley, 1944: The effect of mulches on the root-knot

nematode. Fla. Agr. Exp. Sta. Rpt. for year ending J une 30, 1944:59. Webber, H. J., 1943: Plant characteristics and climatology. In: The Citrus Industry,

ed. by H. J. Webber and L. D. Batchelor. Chapter 2:41-69. Univ. of Calif.

Press, Berkeley. Weber, G. F., 1927: Thread blight, a fungous disease of plants caused by Corticium

stevensii. Fla. Agr. Exp. Sta. Bui. 186:143-162.

------, 1931: Fig rust and its control. Fla. Agr. Exp. Sta. Press Bui. 439:1-2.

Werth, E., 1932: Die wilde Feige im ostlichen Mittelmeergebiet und die Herkunft der

Feigenkultur. Deut. Bot. Gesell. Ber. 50:539-557. Wharton, W. R. M., 1930:

Food and drugs imported are tested at ports for purity.

U. S. Dept. Agr. Yearbook 1930:266-270. Wheeler, L. A., 1927: International trade in dried fruit. U. S. Dept. Com. Trade

Prom. Ser. 44:1-113. (Figs, p. 56-76.) Wickson, E. J., 1888: California Mission fruits. Overland Mo. 11:501-505. Widiez, M., 1932: La culture du figuier en TAfrique du Nord. Agr. Prat, des Pays

Chauds 1932(24): 415-445. Wiegand, E. H., 1936: Preservation of fruits and vegetables by freezing. Oregon Agr.

Exp. Sta. Circ. 116:3-12. Wilcox, E. V., and C. J. Hunn, 1914: Cold storage for tropical fruits. Hawaii Agr.

Exp. Sta. Press Bui. 47:1-12.

\section{Page 206}

Condit

206

The Fig 
Wilde, Julius, 1933: Die Feige in der Pfalz. Pfalzisches Mus. Jahr. 1933: 29-34.

Wildman, J. D., 1933: Note on the use of microorganisms for the production of odors attractive to the dried-fruit beetle. J our. Econ. Ent. 26: 516-517.

Wiley, H. W., 1917: Foods and their adulteration. P. Blakistonl's Son and Co., Philadelphia.

Wille, J. E., 1937: El barreno de los brotes de la higuera en el Peru y su control. [Peru] Min. de Fomento, Dir. Agr. y Ganad. Circ. 37:1-9. (See Rev. Appl. Ent. 25:510.)

Williams, W. J., 1935: Cold storage of figs, raisins, persimmons, quinces and tobacco. Ice and Refrig. 89: 367.

Williamson, Robert, 1887: The fig, its cultivation and preparation for market in California. Calif. State Bd. Hort. Bien. Rpt. 1885 and 1886:294-300.

Winton, A. L., and Kate B. Winton, 1932-1937: The structure and composition of foods. 4 Vols. John Wiley and Sons, New York. (Fig, Vol. 2: 506-512.)

Wohltmann, F., 1892: Handbuch der Tropischen Agrikultur. Leipzig. (See Eisen, p. 301.)

Wolf, F. A., 1911: A disease of the cultivated fig. Ann. Mycol. 9: 622-624.

-----, 1913: Abnormal roots of figs. Phytopathology 3:115-118.

Wolf, F. A., and E. E. Stanford, 1918: A Macrophoma disease of figs. Phytopathology 8:24-27.

Wood, Anne, 1942: Enzymes of the fig. Fruit Prod. Jour. 21: 308-310.

Woodroof, J. G., and J. E. Bailey, 1930: Preserving of fruits by freezing. II. Figs. Ga. Agr. Exp. Sfa. Bui. 164:3-11.

Woodrow, G. M., 1910: Gardening in the tropics. Alex. Gardner, Paisley.

Wright, J ohn, 1891-1894: The fruit growerl's guide. 6 Vols. Virtue and Co., London. (Fig, V. 2:170-200.)

Xenophon (about 430-355 B.C.), 1727: The science of good husbandry. Thomas Corbet, London. Translated by R. Bradley.

Yasaki, M., 1926: On Acrocercops ficuvorella sp. n. Kagoshima Col. Agr. and For. 
Tech. Bui. 6:1-7. (See Rev. Appl. Ent. 16:360.) York, G. K., 1941: Bureau of Market news. Calif. Dept. Agr. Bui. 30:504-540.

1945: Same, Bui. 34:327-375. Yuasa, H., 1934: Notes on Japanese Chrysomelidae. III. Kontyu 8:107-109. (See

Rev. Appl. Ent. 22:522.)

After this volume had been set up we received a copy of Nagaharu (Tyosyun) Satal 's \'Classification of the Species of Philippine Island Plants\', Vol. 1: \'On Ficus (Moraceae), A comparative study of Ficus of the Philippines and Formosal' (1944, pp. 405, 54 plates, entirely in English). This has been published in \'The Research and Survey, No. 143 and 144 of the Research Section of the Bureau of Foreign Affairs, Govt. General of Formosal'. There exists also an ed. with a 289 page supplement (1944), consisting of |'Historical Studies of the Genus Ficus|' (p. 1; "Geographical Studies of the Genus Ficus", p. 41; "Some critical comments on the studies of the problems of the origin of agriculture, with particular reference to the theoretical basis to the systematic studies of horticulture and economic botany", p. 142; "General remarks on the systematic studies of the Genus Ficus", p. 162; "Organographical remarks on the important organs and characters, habits of the Genus Ficus", p. 180; "Charts of the geographic distributions of species of the genus in the world and in the Asiatic regions, together with their explanations"). On pages 37 to 40 of Part 3 (the supplement), the author briefly reviews the history of the domestication of $\mathrm{F}$. carica as gleaned from other authors such as Linnaeus and Solms-Laubach. He makes no mention of the extensive publication by Gustav Eisen entitled, ।'The Fig. I' On page 239 Sata suggests that "the place of origin of the fig is localized in oriental Europe or in the occidental Asiatic regions rather than in western South-Europe or in North African regions."

\section{Index}

\section{Page 207}

INDEX

\section{Page 208}

Aaronsohn, A., 114, 188 Abbott, Ouida, 148, 188 Abyssinia, 19, 20, 21 Acid in figs, 66, 149, 150,153 Aclees cribratus, 179 Acosta, J. de, 13, 188 Acrocercops ficuvorella, 182 Adanson, M., 106, 188 Adoretus horticola, 182 
------versutus, 182

Affleck, T., 15, 188 Afghanistan, 9,12,19, 20, 21, 22, 94 Africa East, 114

North, 160, 180, 183

South, $13,74,95,179,180,182$

Age of trees, 29

Aggery, B., 169, 201

AIGREMONT, 5, 188

Alabama, 14, 27

Alabama argillacea, 185

Albertus Magnus, 37, 188

Albro, F. W., 149

Alcohol, 145

Alexis, 4, 7

Algaida, Gen. Conde de la, 90, 188

Algeria, 24, 32, 33, 46, 50, 58, 71, 72, 81,

$87,105,110,132,133,153,155,156,167$,

180, 181, 182 Alkali, 114 Altemaria tenuis, 176 Altitude, 114 Amend, B. R., 101 Amulets, 5, 6

Anagnostopoulos, P. Th., 177,188 Analyses of ash, 150

------dried figs, 149, 150

------fresh figs, 148,149

gum drops, 63

seeds, 150

Anasa tristis, 182 Anastrepha jrat er cuius, 183 Anderson, L., 154 Anderson, 
W. S., 121,188 Anguillulina pratensis, 178 Anthracnose, 176 Ants, 185 Apogonia, 182 Apriona rugicollis, 179 Arabia, 9,19, 21, 24, 94 Archilochus, 7 Arendt, N. K., 94,188 Argenteuil, 72, 73, 92, 106,118 Argentina, 13, 98,167, 171, 183 Aristophanes, 7,188 Aristotle, 10, 42,154,188

Arizona, 30, 101, 107,114,167, 184

Armillaria mellea, 167

Arnaud, G. \& M., 170, 188

Arundo donax, 134

Asbury, C. E., 128,129, 200

Ascochyta caricae, 170

Asia, 9, 10, 11, 94

Asia Minor, 21, 23, 69, 70, 71,145,176

Aspergillus niger, 173

Aspidiotus lataniae, 181

Aster olecanium pustulans, 181

Athenaeus, 7, 151, 188

Atwater, W. O., 148, 150, 188

Australia, 13, 48, 96, 128, 171, 172, 180,

182, 185 Austria, 144, 156,171 Azochis gripusalis, 180

Bacchus, 2

Back, E. A., 183,188

Bacon, W. M., 162

Bacteria, 130

Bacteriosis, 167

Bacterium fici, 167 
Badie, M., 92, 115, 188

Bailey, J. E., 128, 129, 130, 206

Bailey, S. F., 186,188

Baker, E. E., 138, 188

Baker, E. W., 178,188

Balachowsky, A., 177,179, 181, 188

Balfour, E. G. , 20, 189

Ballou, C. H., 177,189

Banyan, 26

Barber, T. C., 185,199

Barger, W. R., 137,189

Bark, 26

Bark tubers, 26

Barnes, D. R, 186, 193

Barron, A. F., 31, 73, 76, 77, 78, 97, 189

Bartram, John, 14,189

Bartram, Wm, 14, 189

Batchelor, L. D., 205

Batocera lineolata, 179 rufomaculata, 179

Bauhin, K., 18, 189 Beccafico, 179 Becket, T. A, 97 Beckett, E., 98,189 Beetle, borers, 179

------darkling ground, 185 
------ (see dried fruit)

------fig, 183-184

leaf eating, 182

saw-toothed grain, 187

Benavet, J., 145, 155,189

\section{Page 209}

The Fig 209 Index

Benedict, M. R., 132,189

Benson, M., 98, 189

Bermuda, 98, 181

Bernard, Mrs. W. B., 119, 179, 189

Bessey, E. A., 177, 189

Bethel, S., 8, 189

Betts, E., 105, 189

Beverley, G.W., 113, 189

Bezzi, M., 183,189

Bible Times, Fig in, 3

Bioletti, F. TII, 34, 36, 189

Birds, 75, 101,179

Blair, R. R, 52, 189

Blancos, 90

Blank caprifigs, 40, 44, 69

Blapstinus rufipes, 185 
Blastophaga, 13, 16, 24, 29, 38, 39, 40, 42,

$43,44,45,46,47,48,50,52,53,55,57$,

62, 66, 85, 96, 106, 108, 174, 175 Bleaching, 138 Bligh, Capt, 13 Blights, 168

Bloom, 59, 64 Bobone, A., 32, 33, 40, 58, 59, 60, 72, 91,

189 Bodkin, G. E., 181, 189 Boetticher, K., 1, 189 Boissier, E., 20, 22, 189 Bolton, H. E., 13, 189 Bonavia, E., 10, 189 Bondar, G., 180, 189 Bonner, Frances, 171, 204 Borde, A., 152, 189 Bordeaux mixture, 170, 171 Borers, Coleopterous, 95, 98, 179, 180

------ Lepidopterous, 180

Borg, J., 93, 189

Boselli, F. B., 182, 186, 189

Bostrychopsis jesuita, 180

Botany, general, 25

systematic, 18

Botryosphaeria ribis, 168

Botrytis cinerea, 169, 176

Boyd, Mary, 64, 190

Bradley, R., 11, 206

Brain, C K., 180, 182, 185, 190

Brandy, 145

Brann, F. R., 143, 190

Bratley, H. E., 178

Brazil, 168, 180, 182, 183

Brebas, 30, 31, 37, 40, 59, 71, 72, 73, 75,

80, 103, 132 Breeding, 51-55, 94, 95, 100 Brehaut, E., 190 Brickell, J., 14, 
190 Brick pack, 139 Brierly, W. B., 169, 190 Brooks, C, 128, 176, 190

Brookshaw, G., 58, 65, 77, 190

Brown, W. P., 132, 190

Bruschi, Diana, 151, 190

Bryant, A. P., 148

Budd, J. L., 12, 190

Budding, 112

Buds, 27, 28

Bud sports, 112

Bunyard, E. A., 12, 74, 77, 97, 122, 190

Burbank, L., 51, 190

Burger, O. F., 168, 190

Burr, A., 152, 190

Burrknots, 26, 27

Burret, M., 19, 198

Buscalioni, L., 24, 43, 190

Butterfield, H. M., 15, 190

Buxton, P. A., 182, 190

Calavo Growers, 163

Calchas, 2

Caldis, P. D., 174, 190

California, 29, 30, 31, 48, 50, 53, 55, 57, 58, 80, 100, 102, 103, 106, 114, $115,116,117,120,124,126,132,133,134,136,139,141,156,157,159$, $161,169,170,174,178,181$

California Fig Institute, 147, 157, 159, 163, 165, 175, 187, 190 
------ Fruit Exchange, 125

------history, 15

------ Peach and Fig Growers, 142, 157,

$162,163,166$

Calvtno, M., 97, 190

Camphor scale, 181

Candida, 174

Candying, 142

Cankers, 168

Canning, 142, 165

Caprification, 11, 16, 42-50, 54, 55, 75, 83,

86, 88, 91, 108, 149 Caprifig, 29, 30, 31, 32, 40, 46, 50, 53, 54,

$55,59,63,67,68,83,96,118,174,175$,

183 Carles, P., 146, 190 Carpenter, J. C, 15 Carpoglyphus anonymus, 178

------passularum, 178

Carpophilus dimidiatus, 62, 184

------ hemipterus, 184

Cary, H., 195 Cato, M., 7, 190

Cattle feed, Figs for, 90, 91, 154 Cavara, R, 167, 190 Cavolini, R, 43, 190 Celi, G., 19, 190 Celsus, A., 152, 190 Cephalosporium acremonium, 170 Ceratitis capitata, 183 Cercospora bolleana, 170

\section{Page 210}

Condit 
- fid, 170

Ceroplastes rusci, 181

Chace, E. M, 129, 136, 190

Chamberlain, J. W., 98, 191

Chandler, W. H., 40, 104, 129, 191

Chaney, R. W., 9

Charlemagne, 13

Chatfield, C, 148, 191

Checking of skin, 64

Cheema, G. S., 128, 191

Chemistry, 148, 151

Chile, 13, 97, 98, 186

Chimeras, 56, 57

China, 11, 12, 94, 95, 105, 171

Chiswick, 58, 72, 73, 74, 75, 76, 77, 78, 79, 97

Chittenden, F. H., 186, 191

Chloropicrin, 187

Ckoanephora cucurbitarum, 176

Chodat, R., 151, 191

Chomel, P., 152, 191

Christie, A. W., 138, 191

Chromosomes, 40

Chrysopa, 50 
Cladosporium herb arum, 176

Clark, G., 130, 191

Clausen, C. P., 179, 182, 191

Clement-Mullet, J . J ., 196

Cleopatra, 8

Climatology, 83, 103-108

Clough, A. M., 200

Coffee, 25, 144

Coit, J. E., 173, 191

Colby, G. E., 148, 150, 191

Cold storage, 128

Coleman, W., 74, 191

Coleridge, S. T., 5, 191

Collins, J. L., 57, 191

Colobogaster quadridentatus, 180

Color of buds, 28

-----fruit external, 55, 57, 59, 60, 63, US

-----fruit internal, 66, 69

----- leaves, 35

-----petiole, 36

Columella, L. J., 118, 134, 135, 191

Comadre, 91

Common figs, 38, 49, 66, 110 
Common type, 13, 24, 30, 40, 59, 73, 85, 91, 92, 93, 102, 175

Conci, G., 39, 191

Condit, I. J., 15, 25, 30, 38, 40, 43, 49, 52, 53, 57, 61, 68, 69, 70, 71, 73, $74,75,78,79,81,85,86,87,90,91,101,102,112,113,146,148,149$, $167,169,170,171,172,173,191,192$

Condit, Mrs. I. J., 138, 191

Containers for caprifigs, 48

-----dried figs, 86, 139

The Fig

Cook, A. B., 1, 2, 192 Cook, O. R, 23, 192 Cooke, M. C, 169, 192 Cooley, J. L., 121, 192 Corticium laetum, 168

-----salmonicolor, 168

-----stevensii, 168

Cossus cossus, 180 Cotinis nitida, 183 texana, 183

Cotton root rot, 167

Cradein, 150

Cressman, A. W., 177, 179, 181, 192

Cresswell, R., 188

Crete, 10

Croce, F. M., 98, 192

Crops, 30

Crotalaria spectabilis, 178

Crown gall, 167

-----pack, 84 
Cruess, W. V., 129, 141, 142, 143, 144,

145, 147, 149, 151, 192, 194, 196 Cull figs, 86, 87, 91, 138, 175 Cultivation, 121 Culture, 114-123 Cunningham, H. S., 181, 192 Curtius, M. C, 191 Cuttings, 110-112, 115 Cyprus, 93 Cystolith, 35, 36 Cytology, 40 Czapek, F., 150, 192

Dccus zonatus, 183 Dahlgren, B. E., 109, 192 Dalziel, J. M., 110, 192 Da Matta, A, 182, 192 Daniel, Esther P., 154, 192 Dante, 5, 192 Daphnus, 151 Davey, A. E., 174, 192, 195 Davidson, A., 65, 192 Davis, J. J., 183, 192 Davis, M. L., 190 Davis, R. A., 95, 193 Dawson, L, J., 90, 193 Decline of trees, 170 Dehydration, 136 Delassus, M., 180, 193 Deleanu, N. T., 151, 193 Delphyre rufiventris, 182 Dematophora necatrix, 167 Demeter, 1 Demi-fleur, 91 Dermatitis, 65 De Seabra, A. F., 181, 193 Dichogamy, 39 Dickens, C, 8

\section{Page 211}

The Fig 211 Index

Die-back, 169 Dihammus vastator, 180 Dinsmore, J. E., 200 Dionysus, 1, 5 Dipping, 134

Diseases of branch, 167-170 -------fruit, 172-176

------ leaf, 170-172

------ root, 167

------trunk, 167

Distribution, 9, 10, 12 Diversion pool, 165 Donohoe, H. C, 186, 187, 193 Dorstenia, 24

Doughty, C. M., 9, 193

Dragon fly, 50

Dried fig crop, 132-140

Dried Fruit Association, 137, 158, 159,

165, 187 Dried-fruit beetle, 173, 174, 184 Dropping of figs, 172 Drosophila ampelophila, 185 Drummond, O. A. , 168, 193 Drying, 83, 85, 88, 91, 95, 96, 98, 106, 
107, 134

ratio, 90, 134

-yards, 134

DuBreuil, A., 92, 93, 122, 193 Duhamel du Monceau, H. L., 58, 193

Earle, F. S., 99, 115, 141, 193

Eating fresh figs, 131

Ebeling, W., 98

Economics, 156-161

Edgerton, C W., 168, 169, 171, 176, 193

Edson, H. A., 169, 193

Egypt, 10, 19, 27, 92, 115, 160, 171

Eisen, G., 7, 9, 10, 11, 15, 18, 19, 25, 30, 31, 32, 41, 42, 43, 44, 48, 51, 53, $58,59,61,62,63,64,65,66,68,69,70,72,73,76,78,81,85,86,90,91$, $92,93,109,112,113,122,134,135,139,172,193$

Elevation, 95, 101, 114, 181

Elizabeth, Queen, 4, 200

Elleme, 51, 83

Elliot, H. S., 99, 193

Elliott, T., 126, 193

Endosepsis, 47, 50, 54, 174-176

Endosperm, 39

England, 12, 30, 58, 63, 64, 72, 74, 77, 78, 80, 122, 168, 169, 171, 176, 182

Enzymes, 25, 150, 151

Bphestia cautella, 186 
------figulilella, 186

Erbeyli, 51

Erinosyce, 18, 19

Eriophyes fici, 178

Escribano y Perez, J. M., 89, 193

Essig, E. O., 182, 184, 193

Estelrich, P., 32, 58, 90, 109, 120, 193

Etymology, 9

Evaporator, 135

Evelyn, John, 172

Evelyn-White, H. G., 10, 195

Evolution, 23

Ex-lax, 151

Eye, 54, 62, 63, 184

Eye scales, 60, 63

Ezekiel, W. N., 167, 169, 204

Federated Fig Growers, 166 Felton, C C, 7, 193 Ferrari, E., 85, 132, 193

Ferraris, T., 167, 193 Ferris, G. F., 180, 193 Fertilization, 120 Ficin, 25, 50

Fico, 5, 6 Ficus afghanistanica, 20, 21

------bengalensis, 3, 26

------carica, 10, 18, 19, 20, 21, 24, 25, 31,

33, 36, 37, 40, 52, 57, 66, 110, 151 ------caricoides, 20

------ communis, 18

------ geraniifolia, 19, 20, 21 
------glomerata, 110, 177

------gnaphalocarpa, 110

humilis, 18

-indica, 3

------johannis, 19, 20, 21, 24

------ ludens, 21

------tnalvastrifolia, 20, 21

------ morifolia, 21

------palmata, 11, 19, 20, 21, 24, 29, 31, 35,

$36,40,52,54,55,57,61,66,68,103$

------persica, 19, 20, 21, 24

------petitiana, 21

------pseudo-carica, 10, 20, 24, 29, 36, 40,

$52,54,57,61,65,67,68$

------pseudo-sycomorus, 21

------pumila, 57

------ruminalis, 1

------serrata, 19, 20, 21

------virgata, 20, 21, 24

------ vitifolia, 20, 21

Ficusin, 151

Field, Anna, 154, 193, 199 Fig bars, 146

------beetle, 184 
------\& borer, 179

-------bread, 146

Brownies, 146

------bushes, 14, 99, 171

------coffee, 144

------contract, 165

------ crates, 127

\section{Page 212}

Condit 212 The Fig

curculio, 184

eater, 183

------ flats, 126, 127

------ Institutes, 161, 163

------jam, 96, 144

-------meat, 146

------moth, 185

------newtons, 146

------oil, 138, 146

------paste, 144

------pecker, 179

picker, 125

-scale, 180, 181

sue, 8 
------ Sunday, 8

------ syrup, 144, 151

tree, 25

-wasp (see blastophaga)

weevil, 184

-wine, 145

Fig-co, 145 Figdotas, 147 Fignolias, 147 Fig-pie wake, 8

Fischer, W., $161 *$

Flanders, S. E., 38, 44, 180, 181, 192,

193 Flavor, 49, 66, 67 Flecks 65

Fletcher; T. B, 179, 182, 185, 193 Fleur, 90, 91 Floral morphology, 37

Florida, 14, 99, 104, 110, 169, 171, 176,

177, 181. Flowers of fig, 18 Folkard, R., 1, 194 Fong, W. Y, 151, 192, 194

Food value, 153-155 Forbes, J. G., 14, 194 Forkner, J. C, 143, 147, 157, 167, 194 Form of fruit, 60, 172

leaves, 32

Formicomus ionicus, 185 Forskal, P., 19, 20 Fossil figs, 9 Fouche, F. A., 180, 199 Fowler, D. T., 155, 194 Fowler, Mr., 63, 194 Fraga pack, 90, 139

France, $11,12,29,58,92,106,110,119$,

121, 126, 156, 167, 169, 170, 183 Franceschi, F., 20, 68 Francis, P., 26

Frank, T 160, 194 Frankliniella califomica, 186 Fraps, G. S., 148, 204 Fraser, Wm, 8, 194 Frazer, J. G., 1, 2, 194

Freezing fresh figs, 129 French, C, 180, 194 Fresh fig crop, 124-131 Friar, H., 192 Froggatt, J. L., 184, 194 Frost, 45, 89, 101, 103, 105, 120 Frost protection, 105 Fruit characters, 58

------ flies, 183 rots, 176 


\section{-spots, 176}

Fruitfulness, 31 Fulton, H. R., 104 Fumigation, 187 Fusarium moniliforme, 174

------ roseum, 170

Galeruca semipullata, 182

Gallesio, G., 18, 58, 68, 79, 194

Gall flowers, 19, 38

Galloway, B. T., 174, 194

Gandhi, S. R., 95, 119, 194

Ganoderma sessile, 167

Garidel, P. J., 152, 194

Garino-Canina, E., 146, 194

Gasparrini, G., 25, 41, 42, 50, 131, 194

Ge, 1

Geny, 58

Georgia, 51, 52, 59, 76, 99, 115, 121, 129,

130, 169 Gerber, C, 150, 151, 194 Germany, 13, 156 Ghamrawy, A., 92, 115, 188 Giddings, N. J., 169, 194 Girard, A., 148, 194 Girola, C. D., 167, 194

Glaced figs, 142 Glass, Figs under, 122 Glomerella fructigena, 176

------ cingulata, 176

Goff, C. C, 177 Gois, L. A., 145, 194 Gophers, 179

Gordon, Jan \& Cora, 90, 194

Gould, H. P., 99, 114, 121, 194

Grading, 136, 137

Grafting, 112 
Grancini, P., 168, 194

Grandi, G., 24, 43, 44, 50, 180, 190, 194

Graphidothrips stuardoi, 186

Grasovsky, A., 59, 61, 66, 92, 119, 195

Gravenhorst, J. L., 43, 195

Great Britain, 160

Greece, 10, 11, 46, 71, 81, 86, 87, 110, 130,

133, 139, 145, 151, 154, 156, 181, 185 Green, E. E., 182, 195 Growth of trees, 29 Grunberg, A., 183, 195

\section{Page 213}

The Fig 213 Index

Gubela bellicosa, 185

Guglielmi, G., 18, 51, 85, 111, 132, 134,

150, 170, 195 Gulick, C. B., 7, 188 Gummosis, 167 Gunn, D., 180, 185, 195

Habitat, 9

Habit of growth, 29

Hadzits, G. D., 1, 195

Hagan, H. R., 29, 48, 50, 71, 81, 82, 83,

$106,109,117,132,133,136,172,175$,

181, 184, 185, 195 Hahn, F. V., 154, 195 Haines, C G., 184, 195 Hairs on fruit, 25, 34, 65

------leaf, 25, 34, 35

Halit, M., 70, 81, 199 
Hall, J. G., 167, 170, 176, 203

Hallard, J. H., 2, 204

Hanoteau, L. A., 153, 195

Hansen, H. N., 173, 174, 175, 186, 195,

203 Hansen, N. E., 12, 190 Harmon, F. N., III, 195 Harper, F., 189 Harrison, Jane, 2, 195 Harvesting dried figs, 132 Hastings, J., 200 Hatfield, G. D., 199 Hausknecht, 20

Hawaii, 15, 27, 31, 101, 128, 154, 176, 182 Hawes, C. H., 10, 195 Heald, F. D., 167, 170, 171, 195 Heat, 106

Hegardt, C, 18, 42, 195 Hegetaria, 3 Hehn, V., 7, 195 Heilipus bone Hi, 180 Heiny, F., 52, 69, 201 Heintz, A., 87, 195 Hemerophila nemorana, 182 Hempel, A., 182, 195 Henderson, G., 60, 195 Hercothrips fasciatus, 186 Hermaphoditic flowers, 37 Herodotus, 10, 195 Hesiod, 10, 195

Hesperophanes fasciculatus, 179 Heterodera marioni, 177 Hewitt, J. F., 2, 195 Hilgard, E. W., 114, 195 Hill, J ohn, 42, 195 History, 9, 15, 42

Hodgson, R. W., 92, 104, 119, 173, 195 Hog feed, Figs for, 89, 90 Hogg, R., 58, 59, 75, 78, 196 Hollow center figs, 54, 66

Homer, 7, 10, 25, 196

Homotoma ficus, 182

Hone, W., 6, 196

Hoppin, C. A., 14, 196

Horace, 26, 196

Horn, C. L., 181, 196

Horne, W. T., 70, 171, 172, 192

Hort, A., 204

Horton, J. R., 179, 196

Hourda, 83 
Howard, B. J., 136, 174, 196

Howard, C. W., 184, 196

Howard, L. O., 50, 173, 196

Hume, A., 60, 195

Humidity, 83, 95, 99, 107, 128, 137, 171,

173, 174, 176 Hunn, C. J., 128, 206 Hunt, B. W., 52, 55, 76, 99, 196 Husain, M. A., 179, 196 Hutson, J. C, 182, 196 Hyde, H. H., 159, 165 Hylesinus fici, 179 Hypoborus ficus, 179

Ibn-Al-Awam, 109, 196

Ichneumon, 43, 50

Ihering, H. von, 180, 196

Iliad, 7, 10, 25

Iliinsky, A. M., 182, 196

Import duties, 160

Imports, 156

Inbreeding, 53

India, 11, 21, 31, 94, 119, 122, 176, 179,

182, 183, 185 I nfestation, 159 I nhabited caprifigs, 44 Insectiferous, 44

Insects of dried fruit, 140, 186 ------fresh fruit, 183-185

------ leaf, 182

------ tree, 179-182

Insects, scale, 180 Inspection, 157-159 Intercrops, 91, 116 Internal rot, 174 Iris, 63

Irrigation, 119 Irving, W., 14, 196 Isaakides, C. A., 185, 196

Italy, $11,29,42,50,51,53,58,68,70,72,75,79,81,84,85,105,110$, $111,116,130,132,133,134,135,139,145,153,156,167,168,178,180$, 
181,182

Ituna ilione, 182

Izmir, 81, 83, 85, 161

Jack, R. W., 184, 196 J acobs, P. B., 145, 196 J affa, M. E., 153, 154, 196

\section{Page 214}

Condit 214 The Fig

Jam, 144

Jamieson, G. S., 146, 196

Japan, 13, 52, 55, 94, 95, 176, 179, 182,

185 J efferson, Thomas, 12, 13, 105, 109, 196 J onson, Ben, 8, 196 J ope, R., 51

J oslyn, M. A., 129, 196 J uignet, E., 92, 106, 122, 196 J ukovsky, P. M., 81, 196 J uno Caprotina, 2

Kadota Fig Association, 166 Kaloyereas, S., 86, 197 Kearney, T. H., 114, 197 Khan, M. A. W., 179 Kieffer, D. L., 162, 163, 197 King, G., 20, 197 King, H. H., 180, 197 Kino, Father, 13 Koebele, A., 17 Koelz, W., 22, 94 Kojima, T., 179, 197 Krauss, F. S., 5, 197 Kuhrt, W. J., 162, 197

Lagarde, Paul de, 9, 197

Laing, F., 182, 197

La Moglia, J., 147, 192

Lang, A., 26, 204

Langworthy, C. F., 151, 197

Lanham, W. B., 171, 197

La Perouse, Jean, 15, 197

La Quintinie, J. de, 58, 118, 126, 172, 
197 Large trees, 29-30 Latania scale, 181 Latex, 25, 124, 150, 151 Laufer, B., 11, 197 LaWall, C H., 152, 197 Lawrence, D. H., 131, 197 Lawrence, W. H., 101, 197 Laxative properties, 151 Layard, 10 Layer pack, 84 Layering, 109 Lea, A. M., 182, 197 Leaf characters, 32 ------diseases, 170-172 insects, 182

------measurements, 33, 34

----- spots, 170

Leaves for stock food, 88, 155

Leclerc du Sablon, 25, 38, 41, 51, 149,

197 Legare, J. D., 130, 197 Legends, 1, 2 Leick, E., 10, 42, 197

Leite de Vasconcellos, J ., 5, 6, 197 Lelong, B. M., 112, 197 Leonard, M. D., 183, 197 Leonardi, G. , 180, 197 Leonardo da Vinci, 25 Lepe pack, 90 Lepidosaphes ficifoliae, 180

-----ficus, 180

Letourneux, A., 153, 195

Libertella ulcerate, 168

Libya, 92

Lichens, 170

Lichtenstein, J. L., 179, 197

Lime, 121, 150

Limnaecia delicrosella, 185

Lindley, G., 66, 197

Lindley, J ohn, 74, 197

Linnaeus, C, 18, 197

Linsley, E. G. , 186, 187, 197

Lithocyst, 35 
Lobes of leaves, 32, 34, 55, 74, 77

Locoum, 83, 139

Locusts, 185

Lodge, 6

Lonchaea aritsella, 183

Long, J. D., 132, 134, 199

Longo, B., 25, 42, 51, 53, 131, 197

Long-styled flowers, 18, 38, 39, 46

Loudon, J. C, 12, 198

Louisiana, 99, 142, 168, 169, 170, 171, 176,

179, ,81, 182, 185 Loveman, R., 6, 198 Luginbill, P., 183, 192 Lupo, V., 180, 198 Lutz, H. F., 145, 198 Lye peeling, 141

Macaroni pack, 83, 139

McBride, G. M., 97, 198

McColloch, L. P., 176, 190

Mackaness, G., 13, 198

McKeown, K. C, 179, 180, 182, 185, 198

Mackie, D. B., 184, 198

Mackie, G. M., 29, 198

McKinney, R. S., 146, 196

McLaughlin, L., 148

McLester, J. S., 148, 150, 198

MacPherson, D., 160, 198 
Macrophoma fici, 168

Maffei, L 168, 198

Majorca, 64, 89, 132, 138, 145, 151, 154,

155 Malenotti, E., 182, 198 Malta, 93, 167 Mamme, 20, 30, 45, 46, 48, 54, $67,68,69$,

70, 96, 104, 175 Mammoni, 19, 30, 44, 46, 53, 68, 69, 96,

106

\section{Page 215}

The Fig

215

Index

Margaronia brisoalis, 185

Margins of leaves, 34

Markarian, H., 69, 70

Marketing, 161-163

Marsh, G. L., 129, 145, 192, 196

Martelli, G., 181, 198

Martin, J. P., 176

Maslin, E. W., 16, 53, 198

Maslin seedlings, 16, 53, 55, 61, 66, 69

Mason, S. C, 107, 198

Massalongo, C, 41, 198

Massee, G., 168, 171, 176, 198 
Massey, W. R, 51, 55, 106, 109, 135, 198

Matthew, A., 142, 198

Matz, J., 169, 171, 176, 198

Mauri, N., 32, 33, 36, 40, 58, 68, 72, 87,

133, 150, 198 Mazieres, E. de, 93, 135, 198 Mealy bugs, 181 Meander Valley, 29, 46, 71, 81, 83, 107,

117, 119, 132, 134, 161 Meat, 65

Medicinal properties, 152 Mediterranean fruit fly, 183 Meissner, B., 10, 198 Melo Leote, F. C, 33, 91, 198 Menendez, P., 14, 198 Merezhkovskii, D. S., 25, 198 Mesnil, L., 177, 188 Messmate, 50 Metatyges turritus, 184 Methyl bromide, 187 Mexico, 97, 180

Michelbacher, A. E., 186, 187, 197 Micotrichia, 182 Milco, G. N., 69 Mildbraed, J., 19, 198 Miller, C D., 147, 154, 198 Miller, P., 32, 58, 60, 64, 74, 76, 77, 198 Milton, John, 3 Mingioli, E., 132, 198 Miquel, F. A. W., 19, 20, 21 Miranda, V., 119, 198 Mirbel, C. F., 37, 199 Mississippi, 15, 121, 141, 169 Mite, fig, 172, 174, 178

Pacific, 178

Mithridates, 152

M) 'Mahon, B., 77, 199

Mohamet M. S., 149, 199

Mohammed, 11

Mold, 124, 128, 173, 181

Monaster), S., 180, 199

Monohammus mixtus, 184

Monroe, J. F., 32, 58, 59, 61, 63, 66, 99,

203 Moore, T., 63, 199 Moorhead, E. S., 143, 199

Moors, 11 
Mopsus, 2

Moquin-Tandon, A., 41, 199

Morgan, Agnes F., 152, 153, 154, 199

Morganella longispina, 181

Morocco, 91, 145

Morphosphaeria japonica, 182

Morris, H. M., 178, 199

Mosaic, 79, 171

Mosca nera, 183

Moss on trees, 170

Moth, fig, 186

------dried-fruit, 186

------ Indian-meal, 186

leaf feeders, 182

-raisin, 186

------sphinx, 183

Moulton, D., 186, 199

Mrak, E. M., 132, 134, 138, 149, 154, 174,

188, 199 Mucor, 176 Mulching, 177 Mule figs, 42 Muller, W., 145, 199 Munro, H. K., 180, 199 Murakami, S., 182, 199 Muschler, R., 21, 199 Mycosphaerella bolleana, 171 Mytilococcus conchiformis, 180

Nadir, A., 70, 81, 199

Nanism, 29

National Biscuit Co., 146 
Naturel figs, 83

Neck of fig, 61

Nelson, E. K., 149, 199

Nematode, banana, 178

------of blastophaga, 50

------meadow, 178

------ root knot or garden, 53, 99, 101, 110,

177

Newell, W., 185, 199

Newton, H. P., 145, 196

Nichol, A. A., 184, 199

Nichols, P. F., 133, 136, 199

Niphona pecticornis, 180

Nisikado, Y., 176, 199

Niswander, J. F., 162. 199

Noble, E. G., 52, 199

Nodal swellings, 27, 28, 78

No do stoma fulvipes, 182

Noisette, L., 59, 199

North Carolina, 14, 99, 104, 106, 119, 135,

183 Notching, 119 Nujol-treated figs, 146

Oak-root fungus, 167 Ocnerogyia amanda, 182 
Condit 216 Thte Fig

Odor, 29

Odyssey, 7, 10, 58 Oil from fig seeds, 146 Ojima, G., 185, 199 Okahara, K., 151, 199 Oleification, 130 Oliver, G. W., 112, 199 Olivier, G. A., 42, 199

Omophorus stomachosus, 184 Oregon, 101 Origin of fig, 23 Orr, L., 14, 200

Oryzaephilus surinamensis, 187 Osborn, H. T., 182, 200 Oscinosoma discretum, 183 Ostiole, 37, 39, 62, 178 Otiorhynchus cribricollis, 182

Overholser, E. L., 129, 200 Oviedo y Valdes, G., 13, 200 Oviposition, 46

Pachylia ficus, 180, 183

Packing dried figs, 83, 86, 88, 90, 139

------fresh figs, 93, 126

Pacuecos, 90

Pais, E., 1, 200

Paladino, R., 148, 200

Palestine, 12, 29, 30, 92, 109, 114, 119,

181, 182 Pallas, 3 Panetes, 90 Paris, M., 12 Parker, W. B., 140, 200

Parkinson, John, 18, 200 Parthenocarpy, 40, 54, 55, 68, 72 Parthenogenetic endosperm, 39 Partridge, Sarah W., 147, 200 Paste, 144 Patchal, 83 Paton, W. R, 3, 200 Pauly, E. B., 52 Pausanias, 1

Pellicano, A., 51, 85, 132, 148, 150, 200 Pemberton, C. E., 183, 188 Pentzer, W. T., 128, 129, 200 Penzig, O., 41, 200 Pereira Coutinho, A., 33, 200 Persia, 9, 11, 12, 20, 21, 23, 24, 94 Peterson, W. A., 52, 200 Petiole, 36 Petri, L., 167, 200 Phallus, 5 Pharmakoi, 2, 3 Phillips, Edith, 173, 200, 202 Phillips, H., 153, 200 Philotrypesis, 43, 49, 50 Phoma cinerescenSy 168 Phomopsis cinerescens, 168

Phryneta spinator, 179 Phyllosticta fici-carici, 170 Phymatotrichum omnivorum, 167 Physopella fici, 171 Phytalus, 1

Phytomonas tumefaciens, 167 Phytophthora carica, 176

-----fid, 176 palmivora, 176 
Picard, F., 177, 179, 182, 200 Pichard, G., 148, 201 Picking caprifigs, 48 ------fresh figs, 124

Pickled figs, 142

Pierce, N., 174

Piper, S. E., 179, 200

Pistillate flowers, 38, 39, 40, 42, 46

Pittman, H+. A., 172, 200

Planchon, G., 9, 200

Planting, 115

Plant Introduction (P. I.), 71, 72, 75,

79, 110 Plato, 11

Pliny, 58, 75, 79, 118, 130, 153, 200 Plodia interpunctella, 186 Plutarch, 4, 5, 115, 200 Plynteria, 3

Pollen, 39, 44, 46, 47, 48, 52, 54, 55 Polleniferous, 44 Pollination, 16, 24, 39, $42,47,52,55$

------artificial, 48

Pontedera, G., 18, 19, 200

Pony refrigerators, 126

Pope, W. T., 15

Popov, M. G, 21, 23, 200

Porta, G., 79, 200

Portale, F., 85, 115, 135, 200

Portugal, 11, 46, 58, 71, 72, 81, 88, 90,

110, 134, 138, 139, 155, 156, 181, 183 Post, G. E., 3, 21, 200 Potted fig trees, 122 Potts, A. T., 62, 101, 135, 200 Poutiers, R., 183, 200 Powell, A., 
145, 200 Pratylenchus musicola, 178 Precooling, 127 Preserving, 99, 141 Priapus, 5

Price, R. H., 119, 141, 201 Prices, 157, 166

Priego J aramillo, J. M., 90, 201 Processing, 138 Products, 141-147 Profichi, 19, 20, 30, 44, 46, 48, 55, 67, 68,

69, 70, 96, 103 Proliferation, 41 Propagation, 109-112 Protoben pack, 83

\section{Page 217}

The Fig

217

Index

Prunet, A., 169, 201 Pruning, 88, 94, 100, 104, 116-119 Psenocarp, 38

Pseudaonidia duplex, 181 Pseudococctts citri, 182

citrophilus, 182

------filamentosus, 182

------ longispinus, 182

------ maritimus, 182

------matsumotoi, 182

nipae, 182

Psyllids, 182

Ptychodes trilineatus, 179

PUENTE Y OIEA, M., 13, 201

Pulled figs, 139 Pulp, 65, 66, 149 Pustule scale, 181 Pyenson, L., 183, 201

Quality, 66, 67

Quayle, H. J., 183, 184, 201 
Rainfall, 83, 86, 87, 95, 99, 107, 119

Ramachandra Rao, Y., 182, 201

Ravasini, R, 19, 85, 134, 201

Read, F. W., 128, 201

Red spider, 178

Reed, H. M., 52, 128, 129, 130, 133, 135,

136, 141, 142, 144, 199, 201 Reimer, F. C, 99, 105, 115, 119, 121, 201 Reinach, S., 5, 201 Reinach, T 152, 201 Reinhardt, L., 10, 201 Renner, O., 35, 201 Rhisoctonia microsclerotia, 171 Rhizopus nigricans, 176 Ribs of fig, 62 Ritter, Carl, 12, 201 Riviere, A. \& G., 118, 201 Riviere, G., 148, 201

Rixford, G. P., 15, 16, 40, 42, 52, 53, 55,

63, 68, 69, 71, 138, 172, 173, 201, 204 Rjabov, I. N., 52, 201 Robinson, T. R., 52, 204 Roeding, Fred, 17, 69 Roeding, G. C, 15, 16, 29, 48, 53, 69, 70,

71, 81, 113, 201 Rogers, B. B., 7, 188 Rolet, A., 124, 201 Roney, J. N., 168, 204 Root inducing substances, 111 Root-knot, 99, 101, 110, 114 Roots, 25, 167 Rosa, F. de, 85, 201 Rose, D. H., 137, 201 Rosewell, O. W 182, 201 Rothers, B. V., 170, 202 Rouge, E., 151, 191

Roullard, F. P., 167, 202

Roxburgh, W., 20

Royal Hort. Society, 58

Rumina, 1

Rusby, H. H., 151, 152, 202

Russia, 12, 94

Rust, 95, 104, 170, 171

Rust, E. W, 183, 202

Saccardo, P. A., 170, 202

Saccharomyces, 174 
Sale, Edith, 14, 202

Salkind, J., 151, 194

Salmon, E. S., 168, 202

Salt water, 138, 139

Samson, W. H., 70

Sanchez, S., 90, 201

Sanford, S. N. R, 98, 202

San Pedro type, 38, 40, 72

Saporta, G., 9, 202

Sapozhnikova, E. V., 148, 202

Savage, C. G., 48, 96, 202

Savastano, L., 167, 183, 202

Sayre, L. E., 151, 202

Saywell, L. G., 153, 202

Scale insects, $180-181$

Scales of eye, 62,63

Schreiber, W. R., 81, 86, 87, 156, 202

Sclerotinia rolfsii, 169

------sclerotiorum, 169

Schwarz, O., 176, 202

Scott, H., 183, 202

Season, 31, 99

Seedlings, $16,51,52,53,54,56,58,68$, 
73, 76, 95, 177 Seeds, 39, 40, 45, 47, 51, 53, 55, 66, 109,

148, 150, 151 Self-sealed figs, 63 Septobasidium pedicillatum, 169 Serghi, 134, 186 Seron, 91

Serra, Junipero, 15 Sevket, N., 183, 202 Shade cloth, 187 Shakespeare, 5, 8 Shape of fruit, 172 Shear, S. W., 156, 202 Shinn, J. C, 16, 58, 59, 202 Shipping fresh, 126 Shiraiwa, H., 182, 202 Short-styled flowers, 18, 38, 39, 44 Sicily, 85, 115, 139, 155, 180, 183 Silvestri, F., 181, 183, 202 Simmons, C, 96, 202 Simmons, P., 178, 184, 185, 186, 187, 202 Siniscalchi, A., 51, 85, 115, 202 Sinoxylon sexdentatum, 180 - sudanicum, 180

\section{Page 218}

Condit 218 The Fig

Sinuses of leaves, 32, 34 Size of fruit, 54, 61

leaves, 32 tree, 29,30

Skin, 63

Smart, Helen R, 130, 202

Smith, C. O., 167, 203

Smith, Elizabeth, 173, 203

Smith, G. M., 37, 203

Smith, John, 3, 203

Smith, Capt. John, 14, 203

Smith, L. S., 143

Smith, R. E., 53, 168, 169, 173, 174, 175,

176, 203 Smut, 173 Smyrna, 46, 48, 70, 71, 109, 115, 120, 121,

$126,133,138,139,158,175,181,185$,

186, 187 Smyrna type, 13, 16, 38, 40, 46, 53, 54, 55, 
$59,66,71,89,91,92,93,96,108,148$,

150, 172 Smyth, E. G., 134, 186, 203 Softenized figs, 139 Soils, 114 SolmsLaubach, H. G., 9, 19, 20, 21, 25,

42, 68, 203 Solon, 5, 115 Sorber, D. G., 129, 203 Sorting, 136

Souring, 76, 79, 120, 173-174 Spacing of trees, 88, 89, 115 Spain, 11, 46, $58,73,75,78,81,88,89$,

$90,109,119,120,132,139,145,154,156$,

183 Spangler, R. L., 143, 203 Spanish mat figs, 90

------proverb, 64

Sparta, 153

Sparta spartifolium, 134

Spencer, W. G., 190

Spiced figs, 142

Spiders, 50

Splitting, 107, 120, 172

Spoilage, 125

Stahl, A. L., 148, 203

Stalk, 61, 62, 77

Staminate flowers, 20, 38, 39, 44, 55

Standardization of caprifigs, 50

Standley, P. C, 97, 203

Stanford, E. E., 168, 206

Stanford, Gov. L., 16

Stansel, R. H., 25, 52, 55, 62, 99, 100, 
104, 118, 121, 126, 185, 203, 205 Starnes, H. N., 32, 58, 59, 61, 63, 66,

99, 115, 121, 125, 141, 203 Stathmopoda sycastis, 185 Statistics, 156

Steiner, G., 178, 203

Stenoma albella, 180

Stevens, F. L., 167, 170, 176, 203 ,

Stevens, H. J., 169, 192

Stilbum cinnabarinum, 169

Stiner, $H, 187,203$

Stipa Unacissima, 134

Stock food, 154

Stocks, 109, 177

Stone cells, 39

Storage of dried figs, 137

Storey, W. B., 101

Strabo, 9

Streets, R. B., 167, 203

String pack, 87, 139

Strong, L, A., 185, 203

Subba Rao, C. K., 123, 203

Substandard figs, 163, 165

Sugaring of dried figs, 138,140

Sulfuring, 134, 135, 154

Sumner, C., 192 
Sunburn, 170

Surface of leaf, 35

Suzme, 83

Sweat boxes, 134

Swingle, W. T., 9, 15, 16, 17, 18, 42, 43,

50, 53, 63, 68, 203 Sycochymase, 151 Sycomore fig, 110 Syconium, 9, 37, 39, 40, 46, 62 Sycophant, 4, 5 Sykeus, 1

Sylvia hortensis, 179 Symeonides, P. M., 93, 131, 204 Syria, 20, 21, 23, 181 Syrup, 141, 142, 143, 144, 151 ------of figs, 151

Taeniotes scalaris, 180

Tanikawa, T., 52, 55

Tanner, M. A., 199

Tapnets, 91

Tariff, 160

Tarring fig garden, 97

Taubenhaus, J. J., 167, 168, 169, 176, 204

Taylor, A. L., 177, 204

Taylor, C, 50

Taylor, W. A., 16, 204

Teratology, 41

Terminal disbudding, 118, 119

Tessier, P., 176, 204

Testing, 159, 160

Tetranychus pacificus, 178 
Texas, 15, 25, 51, 52, 66, 67, 74, 99, 100, 104, 106, 114, 115, 118, 120, $121,124,126,128,129,130,135,141,142,166,167,168,169,170,171$, $176,179,184,185$

\section{Page 219}

The Fig

219

Index

Texture of leaf, 35 -----pulp, 66

----- skin, 63

Thargelia, 2

Theocritus, 2, 26, 204

Thbophrastus, 10, 26, 31, 37, 42, 58, 109,

110, 130, $167 *$ Thiselton-Dyer, T., 8, 204 Thomas, O., 97, 204 Thompson, Alice, 148, 204 Thomson, D., 122, 204 Thorne, G., 178, 204 Thread blight, 168 Thrips, 62, 173, 174, 186 Thrips tabaci, 186 Thurber, E. R., 167, 204

Thursby, Isabelle S., 143, 147, 204 Tillage, 121

Tims, E. C, 168, 169, 170, 171, 204 Tobacco, Leaves used in, 29 Tolerances, 159 Toomey, W. R, 145, 204 Top-working, 112 Tortyra fulgens, 180

Tournefort, J. P., 42, 204 Towneley, 6, 204 Trabut, L, 24, 43, 50, 52, 58, 87, 181 ,

182, 204 Trachyderes thoracicus, 180 Tragos, 2, 11 Trapping beetles, 185

Traub, H. P., 25, 52, 126, 148, 204 Trays, 134

Tressler, D. K., 138, 205 Trioza buxtoni, 182 Trymatocoecus, 24 Tschirch, A., 19, 205 Tubercularxa fid, 169 Tunis, 92 Turkestan, 12 Turkey, 81, 114, 145, $156,161,167,172$,

183

TURNBULL, A., 14

Turner, W., 96, 205 
Turon figs, 90

Twining Laboratories, 148, 149, 150

Tyler, J ocelyn, 177, 205

Ugarte, 13

Ulysses, 58

Umbrella pack, 83

Umnov, M. P., 182, 183, 205

Uninhabited caprifigs, 44

United States, northern, 98, 105, 171

----- southern, $98,107,114,115,119,124$,

128, 171, 177, 179

Upson, W. F., 144 Utah, 101

Vallese, F., 32, 43, 58, 85, 134, 135, 205

Vancouver, G., 15, 205

Vancouver Island, 97

Van Deman, H. E., 16

Van Lennep, H. J., 152, 205

Van Velzer, A. C, 51, 205

Variegations, 57

Varieties, Abboudi, 92

----- Adam, 72

-----Adriatic, 16, 29, 31, 33, 35, 36, 40,

$49,50,55,56,57,59,60,61,62,66 \mathrm{f} 67,73,76,80,96,102,103,106,115$, $116,120,129,132,134,137,138,144,149,150,154,157,159,162,164$, 
$165,167,172,173,174,185$

-----Allison, 52

-----Angelique, 15, 76

-----Assuani, 92

------Aubique Noire, 79

-----Azendjar, 88

------ Baalie, 35

-----Bardajik, 71, 83, 106, 126, 173

----- Barnissotte, 31, 49, 59, 62, 74, 80

----- Bayadi, 92

-----Beall, 49, 51, 66, 73, 80

----- Biadi, 92

----- Biberaeo, 78

----- Black Provence, 31

----- Black Spanish, 73, 79

----- Blanche, 66, 73

----- Blanche d 'Argenteuil, 72, 73

----- Blanquette, 72, 80, 92

----- Bleasdale, 69

----- Bontard, 66

----- Bordissot Blanca, 89

----- Bourjassotte, 61, 109

----- Bourjassotte Grise, 40, 60, 64, 73, 
97, 122

Bourjassotte Noire, 73, 109

Brebal, 78

Brown Turkey, California, 154 (see

San Piero)

-----------Eastern, 52, 74, 98, 99, 104, 129

----------English, 74, 78, 96, 97

----- Brunswick, 25, 31, 32, 33, 34, 40, 59,

$60,61,62,63,66,67,74,77,79,80,95,96,97,98,99,104,105,115,118$, $124,126,129,142,144,169$

-----Buchrati, 92

California Black, 78

Calimyrna, 47, 120, 135, 138, 157,

159, 162, 164, 165, 175 (see Lob I njir)

----- Cape White, 96

----- Castellana, 62, 66

----- Castle Kennedy, 63, 74, 96

-----Celeste, 30, 33, 52, 59, 61, 62, 74, 75,

$80,99,104,115,121,129,142,169,170,176,177$

\section{Page 220}

Gondit 220 The Fig

----- Cheker Injir, 71

- Clare, 60, 65, 75, 80 


\section{Col de Dame, 61}

Col de Senora Blanca, 75, 76, 89,

122

----- Col de Signora Bianca, 75, 78

----- Col de Signora Nero, 28

------ Constantine, 33, 34, 35

-----\& Cordelia, 19, 66, 68

------ Croisic, 36, 40, 66, 68

----- D।'Agen, 75, 80, 122

------ Datte, 60

Datte Quotidienne, 66

-Dauphine, 66, 72, 78, 80, 92, 95

- Dottato, 29, 31, 33, 35, 36, 40, 49, 50, 51, 54, 59, 62, 63, 65, 66, 67, 75, $77,80,85,102,103,107,110,115,116,117,118,120,124,125,127,129$, $132,133,136,142,143,144,147,148,149,154,176,178$

- Douro Black, 75, 79

------Drap dl 'Or, 76, 78, 79

------ Du Roi, 76

------ Early Violet, 104

----- Eisen, 53

------ Euscaire, 36, 66

----- Excelsior, 66, 68

------ Faiyoumi, 92

----- Figue dl'Or, 76, 77 
Figuier Blanche, 77

-----Fraga, 35, 36, 60, 63, 75, 76, 89, 119

Genoa Black, 64

-White, 28, 60, 76, 80, 96

Gentile, 48, 72

----- Gota de Mel, 63

----- Gouraud Rouge, 28, 59

------Grise de St. J ean, 79

------------Madeleine, 79

-Savantine, 79

Grosse Grise Bifere, 64, 79

Verte, 73, 76, 122

Hamma, 52

Hanover, 32

Hilgard, 53

------Hirta du Japon, 65, 76, 78

------Hunt, 52, 61, 76, 80, 107

------Ischia Black, 36, 59, 60, 77, 80, 97,

122

------------Green, 31, 52, 77, 80, 98, 104

-White, 30, 31, 33, 34, 60, 63,

$77,97,98,122,129$

----- Kadota, 37, 80, 101, 135, 157, 159, 
162, 164, 165, 166 (see Dottato)

-----Kara Ilek, 70

Kassaba, 71

Kearney, 52, 53

----- Khar-roubi, 92

----- Khdari, 61, 92

----- King, 72, 80

-----Lampeira, 72

----- Lemon, 77, 99, 104, 121, 129, 131

----- Lipari, 61

-----Lob Injir, 20, 27, 29, 30, 31, 33, 34,

$35,36,40,47,49,52,54,57,60,61,62,63,67,69,71,80,83,96,101$, $102,103,112,115,117,120,124,125,126,127,128,129,132,137,139$,

$143,144,149,150,154,170,172$

----- Loomis, 69

----- Madeleine, 63, 66, 76, 77, 122

----- Madonna, 74

----- Magnolia, 15, 52, 62, 101, 104, 128,

171 (see Brunswick)

----- Malta Brown, 65, 75

----- Marabout, 35, 36, 60, 61, 80

- Markarian, 69, 70

----- Marseilles, 12, 36, 40, 49, 60, 61, 66,

77, 80, 97, 99, 101, 109, 122 
----- Martinenca, 89

----- Martinique, 60, 61

Mason, 69

----- Masui Dauphine, 95

----- Merioun, 41

----- Messenia, 86

----- Milco, 68, 69, 104

----- Mission, 15, 29, 30, 31, 33, 34, 36,

$40,50,53,54,59,61,62,63,64,66,67$,

$78,80,97,101,102,104,112,115,117,120,124,125,126,127,129,131$, $132,135,137,138,139,144,149,150,151,154,155,157,159,162,164$, 165

----- Monaco Bianco, 61

----- Napolitano, 89

----- Natalino, 78

----- Nebian, 73

----- Negro dl 'Espagne, 79

-----Negro Largo, 63, 79, 96, 97, 98, 122

M) 'eimi, 66

Nerii, 66

-----\& Newcastle, 69

----- Noral, 89

----- Oeil de Perdrix, 31

----- Osborn, 61, 66, 78, 96, 106 
----- Pagaudiere, 72, 78

----- Pajajero, 89

----- Panache, 36, 56, 64, 78, 96

----- Partridge Eye, 59

----- Pasquale, 78

----- Pastiliere, 27, 33, 36, 59, 62, 64, 65,

76,78

----- Peau Dure, 66, 75, 78

----- Petite Marseillaise, 93

-----. Pied de Boeuf, 59, 62, 78, 80

----- Pingo de Mel, 68

----- Poona, 95

----- Poulette, 177

\section{Page 221}

The Fig 221 Index

----- Precoce de Barcelona, 61

----- Quarteria, 77

-----Ramsey, 105

-----Reculver, 78

Reine Blanche, 176

Rixford, 53, 63

Roeding No. 1, 40, 55, 68, 69

No. 2, 26, 29, 69 
-No. 3, 29, 36, 66, 69, 104

-No. 4, 70

- Ronde Noire, 78, 80

----- Ronde Violette Hative, 72

----- Royal Vineyard, 75, 79

----- Samson, 26, 66, 70, 172

---- San Pedro Black, 79

------------White, 60, 66, 72, 73, 80

----- San Piero, 30, 31, 33, 34, 35, 37,

$54,59,62,63,66,67,73,74,75,79,80,95,97,102,104,115,116,118$, $119,120,122,124,125,127,129$

----- San Pietro, 60, 61, 79, 80

----- Sari Lop, 71

----- Serotina, 79

----- Sharrawi, 66

----- Shunnari, 59

- Smari, 109

----- Stanford capri, 34, 66, 70, 104

-----------Smyrna, 29, 71, 112, 172

----- St. Jean, 31, 59, 64, 79, 80

----- St. John, 68

----- Sultane, 27, 35

----- Sultani, 92, 115 
----- Tameriout, 72, 88

Taranimt, 72, 88

Troiano, 79, 85

Turon, 89

-----Verdal Longue, 31, 49, 55, 64, 65,

75,80

-----Verdone, 73

-----Verdoni, 69

----- Vigassotte Bianco, 77

------Violette, 93

----- Violette de Bordeaux, 31, 36, 60, 61,

62

-----West, 53, 55

White Endich, 75

Pacific, 75

-San Pedro, 38, 40, 48

-----Yellow Neches, 61, 62, 65

Variety classification, 59

-----collections, 58, 59, 94, 97

-----description, 67

-----keys, 67

----- list, 80

Varro, M., 27, 205 Vasfi, A., 176, 202 Vasseux, A., 145, 205 Vavilov, N. I., 12,205 
Venation, 34 Venegas, M., 13, 205 Venkata Rao, M. K., 176, 205 Verdejos, 90 Viatkin, V., 105, 205 Vinegar flies, 174, 185

VINOGRADOV-NITITIN, P., 12, 205

Virginia, 14, 99

Virgin Islands, 181

Vitamins, 154

Vitula serratilineella, 186

Viviand-Morel, V., 41, 205

Waitz, J., 59, 61, 66, 92, 119, 195

Wallace, H. C, 158, 163, 205

Walti, A., 151, 205

Warburg, O., 20, 21, 22, 205

Washington, 101

Washington, George, 14

Watson, J. R., 177, 178, 181, 205

Webber, H. J., 108, 205

Weber, G. R, 168, 171, 205

Werth, E., 12, 205

West, W. B., 69

Wharton, W. R. M., 159, 205

Wheeler, L. A., 81, 85, 86, 87, 90, 91,

205 White, E. A., 119, 141, 201 White, O. E., 105 Whitewashing, 170 Wickson, E. J., 15, 205 Widiez, M., 87, 205 Wiegand, E. H., 129, 205 Wilcox, E. V., 128, 206 Wilde, J., 13, 206 Wildman, J. D., 185, 206 Wiley, H. W., 148, 150, 206 Wille, J., 180, 206 Williams, W. J., 128, 206 Williamson, R., 135, 
206 Wind, 83, 107 Wine, Figs in, 144 Winton, A. L. \& Kate, 63, 206

Wohltmann, F., 150, 206 Wolf, F. A., 26, 167, 168, 170, 171, 195,

206 Wood, 2, 5, 26 Wood, Anne, 151, 206 Wood, Jessie L., 169, 193, 194 WooDROOF, J. G., 128, 129, 130, 206 Woodrow, G. M., 94, 206 Woods, C D., 150, 188 Workman, A., 101 Wormald, H., 168, 202 Worthington, J. T., 98 Wright, J ohn, 12, 56, 58, 97, 206 Wyche, R. H., 62, 99, 100, 121, 126, 185,

203

\section{Page 222}

Gondit 222 The Fig

Xenophon, 10, 206

Xerxes, 11

Xylobosca bispinosa, 180

Yarnell, S. H., 52, 201, 203 Yasaki, M., 182, 206

Yeasts, 130, 138, 145, 174 Yields, 99, 124, 132 York, G. K., 157, 206 Yuasa, H., 182, 206

Zygosaccharomyces, 138

Albert R. Mann Library. 2008. Core Historical Literature of Agriculture (CHLA). Ithaca, NY: Albert R. Mann Library, Cornell University. http://chla. library.cornell.edu.

() 2005-2009 Cornell University Library. Questions? Comments? Please contact us. 